
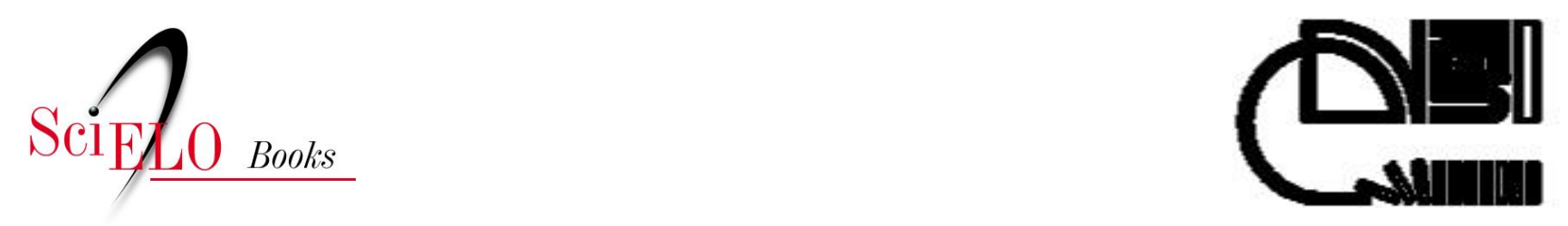

\title{
Produção de identidades e processos de subjetivação em práticas discursivas
}

\author{
Ismara Tasso \\ Pedro Navarro \\ (orgs.)
}

\section{SciELO Books / SciELO Livros / SciELO Libros}

TASSO, I., and NAVARRO, P., orgs. Produção de identidades e processos de subjetivação em práticas discursivas [online]. Maringá: Eduem, 2012. 304 p. ISBN 978-85-7628-583-0. Available from SciELO Books $<$ http://books.scielo.org $>$.

\section{(1)(1)(2)}

All the contents of this chapter, except where otherwise noted, is licensed under a Creative Commons Attribution-Non Commercial-ShareAlike 3.0 Unported.

Todo o conteúdo deste capítulo, exceto quando houver ressalva, é publicado sob a licença Creative Commons Atribuição Uso Não Comercial - Partilha nos Mesmos Termos 3.0 Não adaptada.

Todo el contenido de este capítulo, excepto donde se indique lo contrario, está bajo licencia de la licencia Creative Commons Reconocimento-NoComercial-CompartirIgual 3.0 Unported. 
ProduÇÃO DE
IDENTIDADES E PROCESSOS DE SUBJETIVAÇÃO EM PRÁTICAS DISCURSIVAS 


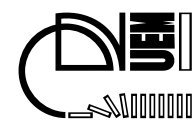

Editora da Universidade Estadual de Maringá

Reitor: Prof. Dr. Júlio Santiago Prates Filho. Vice-Reitora: Profa. Dra. Neusa Altoé. Diretor da Eduem: Prof. Dr. Alessandro de Lucca e Braccini. Editora-Chefe da Eduem: Profa. Dra. Terezinba Oliveira

\section{Conselho Editorial}

Presidente: Prof. Dr. Alessandro de Lucca e Bracini. Editores Científicos: Prof. Adson C. Bozzi Ramatis Lima, Profa. Dra. Ana Lücia Rodrigues, Profa. Dra. Analete Regina Scbelbauer, Prof. Dr. Antonio Ozai da Silva, Prof. Dr. Clóves Cabreira Jobim, Profa. Dra. Eliane Aparecida Sanches Tonolli, Prof. Dr. Eduardo Augusto Tomanik, Prof. Dr. Eliezer Rodrigues de Souto, Profa. Dra. Ismara Eliane Vidal de Souza Tasso, Prof. Dr. Evaristo Atêncio Paredes, Prof. Dr. João Fábio Bertonha, Profa. Dra. Larissa Michelle Lara, Profa. Dra. Luzia Marta Bellini, Prof. Dr. Manoel Messias Alves da Silva, Profa. Dra. Maria Suely Pagliarini, Profa. Dra. Maria Cristina Gomes Machado, Prof. Dr. Oswaldo Curty da Motta Lima, Prof. Dr. Raymundo de Lima, Prof. Dr. Reginaldo Benedito Dias, Prof. Dr. Ronald José Barth Pinto, Profa. Dra. Rosilda das Neves Alves, Profa. Dra. Terezinha Oliveira, Prof. Dr. Valdeni Soliani Franco, Profa. Dra. Valéria Soares de Assis.

\section{Equipe Técnica}

Fluxo Editorial: Edilson Damasio, Edneire Franciscon Jacob, Mônica Tanamati Hundżinski, Vania Cristina Scomparin. Projeto Gráfico e Design: Marcos Kazuyoshi Sassaka. Artes Gráficas: Luiano Wilian da Silva, Marcos Roberto Andreussi. Marketing: Marcos Cipriano da Silva. Comercialização: Norberto Pereira da Silva, Paulo Bento da Silva, Solange Marly Osbima. 
Ismara Tasso

Pedro Navarro

Organizadores

PRODUÇÃO DE
IDENTIDADES

E PROCESSOS DE SUBJETIVAÇÃO EM PRÁTICAS DISCURSIVAS

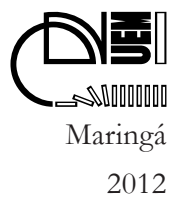


Copyright (C) 2012 para os autores

Todos os direitos reservados. Proibida a reprodução, mesmo parcial, por qualquer processo mecânico, eletrônico, reprográfico etc., sem a autorização, por escrito, dos autores.

Todos os direitos reservados desta edição 2012 para Eduem.

Revisão textual e gramatical: Raul Pimenta

Normalização textual e de referências: Jefferson Gustavo dos Santos Campos

Projeto gráfico/diagramação: Marcos Kazuyoshi Sassaka

Imagens: fornecidas pelo autor

Capa: Cristina Tavares e Cristiane Martioro

Ficha catalográfica: Edilson Damasio (CRB 9-1123)

Fonte: Garamond

Tiragem - versão impressa: 500 exemplares

Dados Internacionais de Catalogação-na-Publicação (CIP)

(Eduem - UEM, Maringá - PR., Brasil)

P964 Produção de identidades e processos de subjetivação em práticas discursivas / Ismara Tasso , Pedro Navarro (organizadores). -- Maringá : Eduem, 2012.

304 p. : il., fotos (color.).

Vários autores.

ISBN 978-85-7628-429-1

1. Análise do discurso. 2. Discurso. 3. Identidade. 4. Práticas discursivas. 5. Corpo. 6. Mídia. 7. Exclusão/inclusão. I. Tasso, Ismara, org. II. Navarro, Pedro, org. III. Título.

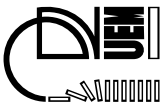

Eduem - Editora da Universidade Estadual de Maringá

Av. Colombo, 5790 - Bloco 40 - Campus Universitário

87020-900 - Maringá-Paraná - Fone: (0xx44) 3011-4103 - Fax: (0xx44) 3011-1392

www.eduem.uem.br - eduem@uem.br 


\section{SUMÁRIO}

APRESENTAÇÃO

Primeira parte

SUJEITO E CORPO NA ORDEM DOS DISCURSOS:

EFEITOS DO BIOPODER

O corpo moldado: corporeidade mediada e subjetivação

Poliana Lachi, Pedro Navarro

Discurso e biopolítica na sociedade de controle Kátia Menezes de Sousa ............................................................

O corpo tatuado: a imagem de uma identidade em 3D

Roselene de Fátima Coito...

Segunda parte

DISCURSO E NORMALIZAÇÃO DOS SUJEITOS: IMAGENS DE EXCLUSÃO/INCLUSÃO

Mídia e estratégias de governamentalidade do corpo deficiente: políticas públicas afirmativas e identidade em tela

Érica Danielle Silva, Ismara Tasso ............................................

Doente e pecador: ecos do século XIX sobre a homossexualidade na imprensa oficial (1985-2010) Alexandre Sebastião Ferrari Soares. 


\section{Terceira parte}

SUJEITO, PRODUÇÃO DE IDENTIDADES E SUBJETIVAÇÃO

O "Sapo Barbudo" e o "Lulinha paz e amor": as identidades de Lula construídas pela mídia na campanha de $\mathbf{2 0 0 2}$

Elaine de Moraes Santos, Edson Carlos Romualdo

Misoginia e anticomunismo na xilogravura de cordel

Cláudia Rejanne Pinheiro Grangeiro

Memória, mulher e política: do governo das capitanias à presidência da república, rompendo barreiras

Maria da Conceição Fonseca-Silva

Identidades do masculino no humor

Adélli Bortolon Bazza, Maria Célia Corter Passetti

Representações da masculinidade em crise: legados pós-modernos

Daiany Bonácio

Ser mulher na atualidade: a representação discursiva da identidade feminina em quadros humorísticos de Maitena

Érika de Moraes

Professor: sujeito e objeto na revista Nova Escola Adriana Beloti, Pedro Navarro. 


\section{APRESENTAÇÃO}

A proposta de organização de um livro que reunisse estudos sobre a relação entre discurso e sujeito nasceu da necessidade que tínhamos de apresentar à comunidade acadêmica e aos demais interessados nessa questão parte dos resultados de um projeto de pesquisa mais abrangente que, sob o título "Práticas identitárias na pós-Modernidade: discurso, sentido e mídia", analisou, de 2004 a 2009, um conjunto significativo de textos de diferentes linguagens extraídos dos meios de comunicação impresso e televisivo que focalizam os campos político e educacional, temas do universo masculino e feminino, questões relativas ao controle, à disciplina e ao governo dos corpos e à problemática da inclusão/exclusão social. Esse compêndio, além de conter artigos de pesquisadores envolvidos diretamente com esse projeto, contempla também textos de professores de outras instituições para os quais a referida relação é objeto constante de reflexão, tanto teórica quanto analítica, a partir de pressupostos linguísticos, filosóficos, sociológicos e históricos que, não obstante estarem fundados em solos epistemológicos por vezes distintos, permitem analisar discurso e sujeito à luz de uma perspectiva discursiva de linguagem.

Poderíamos considerar que o fio condutor que alinhava os artigos que seguem busca, como finalidade última, respostas

1 Projeto subsidiado pela Fundação Araucária. 
a uma questão filosófica e contemporânea: "Quem somos nós hoje?”; ou, mais especificamente, "Quem é esse sujeito produzido no interior de práticas discursivas dominantes que têm lugar na mídia brasileira?". Em certa medida, as análises aqui realizadas das materialidades midiáticas podem oferecer ao leitor uma compreensão geral do tipo de saber que se forma sobre os sujeitos investigados em cada um dos artigos e do tipo de poder que se exerce nessas práticas. Como é de conhecimento, a consideração da relação entre saber e poder nos discursos das Ciências Humanas sobre o homem é feita por Foucault ${ }^{2}$ no momento em que o filósofo analisa os mecanismos de poder no interior dos discursos científicos, com a finalidade de responder à seguinte interrogação: "a qual regra somos obrigados a obedecer, em uma certa época, quando se quer ter um discurso científico sobre a vida, sobre a história natural, sobre a economia política?" (FOUCAULT, 2000, p. 226-27).

Os artigos que compõem esta organização estão divididos em três grandes eixos temáticos. Na primeira parte foram reunidos os textos que discutem, em linhas gerais, o controle do corpo e o governo dos sujeitos. $\mathrm{Na}$ segunda parte se encontram artigos que versam sobre representações do brasileiro marginalizado em interface com a exclusão e a inclusão. Os textos inseridos na terceira e última parte tomam como objetos de análise as representações do masculino e do feminino no público e no privado, a produção de identidades do sujeito político e os processos de subjetivação docente.

Iniciando a primeira parte, no texto "O corpo moldado: corporeidade mediada e subjetivação”, Poliana Lachi e Pedro

2 FOUCAULT, M. As palavras e as coisas: uma arqueologia das ciências humanas. Trad. Salma T. Muchail, 8. ed. São Paulo: Martins Fontes, 2000. 
Navarro analisam textos de revistas impressas, com a finalidade de compreender o funcionamento do discurso que ali se manifesta sobre o corpo e suas formas de subjetivação. As reflexões feitas a partir dos enunciados analisados permitem observar que o corpo dos sujeitos é uma construção discursiva produzida pela mídia conforme as relações de saber e de poder articuladas no histórico e no social. Trata-se de um "corpo de sentidos" que não preexiste aos discursos, uma vez que é criado no acontecimento e na sua objetivação pelos saberes.

Ao considerar os efeitos do biopoder sobre os corpos, Kátia Menezes de Sousa, em "Discurso e biopolítica na sociedade de controle", analisa um conjunto de enunciados que dá forma de existência aos discursos políticos na atualidade brasileira por meio de campanhas sociais dos governos. O recorte feito confere visibilidade aos efeitos de um poder disciplinador e normalizador que se exerce com pretensões de administrar a vida e o corpo da população.

A relação entre discurso, sujeito e corpo é tema das discussões e das análises realizadas por Roselene de Fátima Coito, em "O corpo tatuado: a imagem de uma identidade em 3D". No artigo a autora reflete sobre a tatuagem em sua manifestação histórica e na historicidade do dizer inscrito nos corpos. Para tanto, interroga o dispositivo de análise e o objeto de estudos que permitiriam traçar um perfil da construção identitária de coletividades e de individualidades, desvelando a História como superfície de opressão, como singularidade de identidades e como biopoder.

Abrindo as discussões propostas na segunda parte, no texto "Mídia e estratégias de governamentalidade do corpo deficiente: políticas públicas afirmativas e identidade em tela", as autoras 
Érica Danielle Silva e Ismara Tasso, considerando a mídia televisiva como superfície de inscrição de enunciados que retomam, deslocam e ressignificam sentidos sobre o corpo deficiente, propõem demonstrar como se dá a constituição da identidade do sujeito com deficiência, no exercício da governamentalidade. Essa análise não se faz sem um questionamento basilar sobre o que se diz das pessoas com deficiência, sobre o modo como se dá a constituição identitária dos sujeitos com deficiência e sobre os sentidos do que se diz do corpo deficiente, cuja espetacularização é ou não agradável ao olhar.

Alexandre Sebastião Ferrari Soares encerra essa segunda parte com o texto "Doente e pecador: ecos do século XIX sobre a homossexualidade na imprensa oficial (1985-2010)", no qual se propõe a analisar "os sítios de significância" que foram se estabelecendo na imprensa oficial sobre o homossexual e seu estilo de vida entre os anos de 1985 e 1990 e entre os de 2005 e 2010. Sua finalidade, como salienta, não é analisar a resistência ao discurso hegemônico sobre os homossexuais na imprensa oficial, mas compreender quais sentidos continuam ecoando na imprensa brasileira de circulação nacional, colocando o homossexual na ordem do dia.

A terceira parte traz inicialmente três estudos que focalizam aspectos discursivos produtores de identidades do sujeito político. Em “' $O$ 'sapo barbudo' e o 'Lulinha paz e amor': as identidades de Lula construídas pela mídia na campanha de 2002", Elaine de Moraes Santos e Edson Carlos Romualdo analisam capas das revistas IstoÉ e Veja editadas no período eleitoral de $2002 \mathrm{em}$ que o concorrente petista foi objeto de reportagem. O gesto de interpretação dos autores tem por meta mostrar como se publicizou a ideia da dupla identidade de um candidato-corpo do PT e, a partir da discursivização das identidades de Lula 
pela imprensa, esboçar uma possibilidade de explicação para a fragmentação identitária do sujeito político pós-moderno.

Já o texto de Cláudia Rejanne Pinheiro Grangeiro, intitulado "Misoginia e anticomunismo na xilogravura de cordel", realiza uma reflexão sobre os mecanismos de constituição da subjetividade feminina no âmbito do discurso político. A materialidade sobre a qual se debruça é uma xilogravura da capa do polêmico folheto "Engana-me que eu gosto 2", de Abraão Batista, que circulou em Juazeiro do Norte - CE por ocasião das eleições para prefeito daquela cidade em 2000, após a interdição judicial do primeiro folheto: "Enganame que eu gosto". Grangeiro conclui que os mecanismos de constituição de identidade do sujeito político feminino, a partir da xilogravura, atuam no sentido de desqualificar o discurso da candidata do PT nas referidas eleições.

Tomando como foco a relação discurso, política e mulher, no artigo "Memória, mulher e política: do governo das capitanias à presidência da república, rompendo barreiras", Maria da Conceição Fonseca-Silva faz uma discussão histórica e discursiva sobre a constituição e a transformação da mulher como sujeito político. Mostra que, na materialidade discursiva das formulações postas em circulação na sociedade, os sentidos das formulações sobre mulher e política não são logicamente estabilizados, haja vista que, segundo a autora, "gerações de mulheres brasileiras, independente de raça ou classe social, subjetivaram no lugar de resistência, lutaram e lutam, promovendo, conforme as condições de possibilidade de cada época".

Os três estudos seguintes problematizam aspectos da chamada "crise de identidade" do homem e da mulher, atentando 
para o fato de que as transformações pelas quais passam esses sujeitos constituem e produzem determinados efeitos de sentido nos discursos midiáticos sob investigação.

É o que mostram Adélli Bortolon Bazza e Maria Célia Cortez Passetti, em "Identidades do masculino no humor". No artigo são analisadas cenas do programa "Sexo Frágil", exibido pela Rede Globo no ano de 2003, com o objetivo de observar como as identidades de masculino são representadas e como se pode criar o humor a partir delas. De acordo com as análises feitas, no programa há tanto a criação de uma identidade de homem machista quanto a construção de um sujeito que tem a necessidade de se desligar dessa identidade para conviver na sociedade atual, fato que torna risíveis esses personagens e suas identidades.

A crise de identidade do homem, na mídia contemporânea, é também tema de estudo de Daiany Bonácio. No texto "Representações da masculinidade em crise: legados pósmodernos" a autora argumenta que os discursos que circulam na mídia sobre o chamado "novo homem" promovem uma espécie de desconstrução da "velha" imagem masculina de indivíduo forte e machista. Os elementos discursivos que concorrem para essa representação empregam estratégias linguísticas e imagéticas altamente excludentes e idealizadas

Fechando essa discussão sobre as identidades masculina e feminina, o artigo "Ser mulher na atualidade: a representação discursiva da identidade feminina em quadros humorísticos de Maitena", de Érika de Moraes, realiza um movimento de descrição/interpretação do modo como os discursos sobre a mulher emergem no humor e se confundem com a "realidade" sobre ela, produzindo efeitos na constituição da atual identidade 
feminina. Para essa autora, determinados discursos, chamados de "androcentristas", ainda circulam em diferentes espaços que não o humorístico. Não obstante sua sutileza, tais discursos podem emergir "nos vãos escorregadios da linguagem, nos interstícios do texto, nos quais se mostram os posicionamentos dos sujeitos enunciadores".

Finalizando a terceira parte e o livro, as discussões sobre discurso e sujeito saem do âmbito político e cultural para tratar de um campo em que a experiência da subjetividade é vista sob o entrelaçamento do educacional com o midiático.

Assim, o percurso de análise feito por Adriana Beloti e Pedro Navarro no texto "Professor: sujeito e objeto na revista Nova Escola" busca compreender como esse meio de comunicação materializa em seus enunciados processos de subjetivação do sujeito professor. De acordo com as análises, saberes advindos das teorias dos gêneros textuais, por exemplo, atravessam os enunciados, produzindo a experiência da subjetividade docente. Esse processo de subjetivação se efetua e é legitimado por uma série de dispositivos do tipo exemplos e reflexões sobre "boas" propostas pedagógicas, com teorias, objetivos, metodologias e conteúdos, determinação dos conteúdos a serem trabalhados e ensinados, e o governo de si pelo governo dos outros.

Não é demais desejar que, ao final do trajeto aqui empreendido pelos autores, nossos possíveis interlocutores possam extrair dele um caminho teórico e metodológico que permita compreender como se materializa a produção do sujeito em discursos midiáticos. Mais ainda, esperamos que o trabalho de descrição e compreensão desses discursos possa lançar luz sobre tantos outros estudos que reclamam, hoje, um gesto político de pesquisadores comprometidos - como desejava 
Michel Foucault ${ }^{3}$ - não em dizer a muda verdade de todos, mas em lutar contra as formas de poder "ali onde ele é, ao mesmo tempo, o objeto e o instrumento disso: na ordem do 'saber', da 'verdade', da 'consciência', do 'discurso"' (FOUCAULT, 2006, p. 39). Isso requer o empreendimento de pesquisas que desvelem a evidência e a correspondência supostas entre aquilo que os homens enunciam e os sujeitos que são produzidos a partir dos enunciados.

Os organizadores.

3 FOUCAULT, M. Estratégia, poder-saber/Michel Foucault. Coleção Ditos \& Escritos, v. IV. Organização e coleção de textos de Manoel Barros da Motta. Tradução de Vera Lúcia Avellar Ribeiro, 2. ed, Rio de Janeiro: Forense Universitária, 2006. 


\section{Primeira parte}

Sujeito e corpo na ordem dos discursos: efeitos do biopoder 



\section{O CORPO MOLDADO: CORPOREIDADE MEDIADA E SUBJETIVAÇÃO Poliana Lachi ${ }^{4}$, Pedro Navarro ${ }^{5}$}

Não é de hoje que a ciência busca compreender a origem do homem, os seus modos de agir e a sua relação em sociedade. Se na Antiguidade esse processo se dava por meio da religião, do misticismo crente em magias e atos sobrenaturais, com o surgimento da ciência moderna, de base empírica, os saberes ganharam um novo peso de verdade e passaram para um novo estatuto, embora não tenham deixado de estar ligados à elite.

Foucault faz dessa questão a sua maior inquietação. $\mathrm{O}$ desvendamento do sujeito moderno não ocorre apenas em $A s$ palavras e as coisas, mas é um pensamento que transpassa toda a sua obra, inclusive aquelas que tematizam o poder, o saber e a ética. Considerando essa busca por um sentido do homem atual e tomando-a como aspecto investigativo, este artigo propõe lançar um breve olhar sobre o discurso a respeito do corpo e suas formas de subjetivação. Para isso, em um primeiro momento realizará uma articulação teórica entre diferentes noções que, quando organizadas e entrelaçadas, permitem compreender os efeitos de sentido dos discursos sobre o corpo do sujeito e a sua

\footnotetext{
4 Mestre pelo Programa de Pós- Graduação em Letras da UEM.

5 Professor do Departamento de Letras e do Programa de Pós- Graduação em Letras da UEM.
} 
identidade: modernidade, identidade, mídia e corpo; o segundo momento se constituirá em breve apresentação de resultados obtidos em pesquisa anterior ${ }^{6}$.

\section{Modernidade e identidade}

Para Giddens (2002), mais do que um simples período histórico, o termo "modernidade" representa todo um conjunto de práticas comportamentais e instituições que afetam o mundo de forma global e que são posteriores ao período feudal europeu. Para o autor, essas instituições diferem drasticamente daquelas que as precederam, fato que se deve ao seu dinamismo e ao impacto de ordem global que alcançaram, pois a chegada da Modernidade altera o cotidiano dos sujeitos, seja nos aspectos sociais seja nos pessoais: ela "deve ser entendida num nível institucional; mas as transformações introduzidas pelas instituições modernas se entrelaçam de maneira direta com a vida individual, e portanto com o eu". (GIDDENS, 2002, p. 9).

Longe de ser homogênea, para Bauman (2001), a Modernidade pode ser vista, num primeiro momento, como algo 'sólido', e em outro, como 'leve', 'fluido' ou ‘líquido'. Neste último, considera-se que "os líquidos, diferentemente dos sólidos, não mantêm sua forma com facilidade. Os fluidos, por assim dizer, não fixam o espaço nem prendem o tempo". (BAUMAN, 2001, p. 8). Essa metáfora, construída pelo autor para caracterizar esse

6 Este artigo consiste em um recorte da pesquisa desenvolvida pela autora em sua dissertação, intitulada Um corpo de sentidos: discurso, subjetividade e midia, desenvolvida na Universidade Estadual de Maringá sob a orientação do professor Dr. Pedro Navarro. 
novo aspecto da Modernidade, explica perfeitamente o que é a contemporaneidade. Esta é fluida, pois se move com facilidade, altera o seu estado e assume qualquer forma, e assim está sempre pronta para se reconfigurar.

Observa-se na Modernidade um avanço do mundo industrializado, com a utilização de maquinários e da força material nos processos de produção; entretanto essa industrialização não deve ser compreendida como a sua única dimensão, pois há outro fator que marca presença de forma drástica: o capitalismo - um "sistema de produção de mercadorias que envolve tanto mercados competitivos quanto a mercantilização da força de trabalho". (GIDDENS, 2002, p. 21).

Ocorre ainda um esvaziamento das noções de tempo e espaço, que se separam tanto de si quanto do que Bauman (2001) chama de "práticas da vida" e passam a se caracterizar como categorias distintas; assim, "um mundo com um sistema de tempo universal e zonas de tempo globalmente padronizadas como o nosso hoje, e social e experiencialmente diferente de todas as eras pré-modernas”. (GIDDENS, 2002, p. 23).

Se a Modernidade produz mudanças em todos os aspectos da vida social e em todas as instituições, não é de estranhar que ela possibilite uma ressignificação da instância última da sociedade: o sujeito. Essa é uma das formas pelas quais atua a reflexividade da Modernidade. Para Giddens (2002, p. 10),

a reorganização do tempo e do espaço, somada aos mecanismos de desencaixe, radicaliza e globaliza traços institucionais preestabelecidos da Modernidade; e atua na transformação do conteúdo e da natureza da vida social cotidiana.

Assim, ao afetar a vida cotidiana, afeta também o indivíduo. Pensar na identidade desse sujeito moderno é considerar que as 
estruturas às quais ele se ligava já não são fixas. Se houve uma liquidificação da sociedade, o sujeito que se prendia a ela passa por uma desestruturação. Para Hall (2006), esse sujeito se destaca por não possuir uma identidade fixa, essencial ou permanente. Como os líquidos, as identidades modernas estão sempre em movimento, tomando novos formatos - que logo serão perdidos para que outros assumam o seu lugar. Elas não se prendem a um único formato, uma única configuração: "O sujeito assume identidades diferentes em diferentes momentos, identidades que não são unificadas ao redor de um 'eu' coerente” (HALL, 2006, p. 13).

Hall (2006) reforça esse sentido de contradição das identidades modernas. Para esse autor, se elas parecem unificadas, isso se deve a uma fantasia ilusória que o indivíduo forma ao construir a sua narrativa biográfica. Assim, a identidade moderna se constitui a partir da chamada "crise de identidade". Para Bauman (2005, p. 30), a partir do momento em que a identidade perde as âncoras sociais que lhe conferiam o aspecto de natural, inegociável e predeterminada, para o sujeito se torna ainda mais importante a identificação. Dessa forma, pensar em identidade só se tornou possível a partir dessa crise de pertencimento.

Laclau (apud HALL, 2006) aponta as sociedades modernas como descentradas, deslocadas por forças exteriores a ela. Essas sociedades "são atravessadas por diferentes divisões e antagonismos sociais que produzem uma variedade de diferentes 'posições de sujeito' - isto é, identidades - para os indivíduos” (HALL, 2006, p. 17). Há então o fenômeno da pluralização das identidades, que possibilita ao sujeito uma diversidade de posições que podem ser assumidas e que promovem novas identidades, papéis que nem sempre estarão em harmonia. 
Nessa busca pela identificação entra em jogo a questão da diferença, que não se contrapõe à identificação, nem a exclui, mas, contrariamente, identidade e diferença dependem uma da outra (SILVA, 2007). Afirmar uma identidade só faz sentido porque faz parte de uma cadeia de negações: ser algo só significa porque não é outra coisa. O mesmo ocorre com a questão da diferença, que se constitui como tal apenas em relação às afirmações de identidade. (SILVA, 2007, p. 75).

A representação e marcação da identidade se dão por meio dos símbolos. Segundo Woodward (2007, p. 10), "existe uma associação entre a identidade da pessoa e as coisas que uma pessoa usa". Para a autora, que em seu texto toma como exemplificação as discussões sobre as identidades dos sérvios e croatas em meio a uma disputa política, o cigarro fumado por um indivíduo, por exemplo, pode indicar seu pertencimento a essa ou àquela identidade nacional; por isso essa identidade é tanto social quando simbólica (WOODWARD, 2007).

Essa identidade - fragmentada, líquida - que se dá por meio da diferença e é marcada por símbolos, é vista também como construída no discurso, pois as posições assumidas pelos sujeitos implicam a sua identidade - até mesmo no sentido de que a própria língua utilizada pelo indivíduo é constitutiva de um sentido de pertencimento a uma nação, a um lugar (WOODWARD, 2007):

[...] quaisquer que sejam os conjuntos de significados construídos pelos discursos, eles só podem ser eficazes se eles nos recrutam como sujeitos. Os sujeitos são, assim, sujeitados ao discurso e devem, eles próprios, assumi-lo como indivíduos que, dessa forma, se posicionam a si próprios. As posições que assumimos e com as quais nos identificamos constituem nossas identidades (WOODWARD, 2007, p. 55). 
Os sentidos então se dão conforme a posição tomada pelo sujeito, porém esse mesmo sujeito é produzido pelo discurso a partir de formações discursivas. Sendo assim, diante das inúmeras discussões a respeito da identidade e das perspectivas de abordagem dessa noção, é no cruzamento entre esses sujeitos e as práticas discursivas que a identificação será apreendida (HALL, 2007). Tal identificação, na perspectiva discursiva, é tida sempre como um processo nunca completado, pois a qualquer momento ela pode ser sustentada ou abandonada.

\section{Por que a mídia?}

O avanço da tecnologia proporcionou também o desenvolvimento e a globalização dos meios de comunicação, fazendo-os integrar-se na vida social de forma regular e possibilitando que os produtos da mídia passassem a circular em amplitude internacional (THOMPSON, 2008). Essa extensão dos meios de comunicação mostra a sua importância diante dos aspectos sociais, uma vez que a própria comunicação é um aspecto central da vida dos indivíduos e, como aponta Thompson (2008, p. 19), "de uma forma profunda e irreversível, o desenvolvimento da mídia transformou a natureza da produção e do intercâmbio simbólicos no mundo moderno". Esse simbolismo de que são dotados os meios de comunicação se refere tanto à produção quanto ao tratamento dos materiais significativos para os indivíduos.

A comunicação é tida pelo autor como "um tipo distinto de atividade social que envolve a produção, a transmissão e a 
recepção de formas simbólicas e implica a utilização de recursos de vários tipos" (THOMPSON, 2008, p. 25). Nessa perspectiva, cabe destacar a mídia em massa, que é uma forma de produção de conteúdo simbólico por meio de fixação e transmissão. Ela está ligada a instituições e seus produtos estão disponíveis a uma grande quantidade de indivíduos (THOMPSON, 2008). Para Thompson (2008), esse tipo de comunicação se caracteriza por cinco aspectos, a saber:

1) os meios técnicos e institucionais, os quais envolvem certos tipos de tecnologia e certas inovações tecnológicas que são também explorados comercialmente e ocorrem dentro de instituições, tornando possível o surgimento da indústria da mídia;

2) a mercantilização, pois, para o autor, os produtos midiáticos podem receber dois tipos de valorização: um valor simbólico, atribuído de forma subjetiva e/ ou emocional, e um valor econômico, que corresponde à atribuição de um valor ao produto por meio do qual ele pode ser trocado no mercado e está ligado à mercantilização, que transforma as formas simbólicas e produtos da mídia em mercadorias;

3) dissociação estrutural entre produção e recepção das formas simbólicas: nas comunicações em massa os contextos de produção e recepção geralmente se diferenciam, o que implica também que a comunicação flui em um único sentido, sem o feedback característico de uma conversação face a face; mas isto não impede que a indústria da mídia tente contornar esse fator, pois atua por meio de pesquisas mercadológicas (THOMPSON, 2008); 
4) distribuição das formas simbólicas no tempo e no espaço, pois os produtos estão disponíveis em outros contextos além daqueles dos quais eles surgem, podendo alcançar contextos mais distantes daqueles originários (THOMSPON, 2008);

5) distribuição pública das formas simbólicas, o que significa que os produtos da mídia ficam disponíveis a uma pluralidade de destinatários, de forma que aqueles que dispõem de meios técnicos e financeiros passam a adquiri-los, embora eles se restrinjam a uma pequena margem da população (THOMSPON, 2008).

Para Giddens (2002), a mídia atua como uma expressão e instrumento das tendências globalizantes da Modernidade: "em suma, nas condições da Modernidade, os meios de comunicação não espelham realidades, mas em parte as formam" (GIDDENS, 2002, p. 32); e ao formar (e transformar) a sociedade, a mídia influencia também os sujeitos. Ao trazer os eventos, a mídia proporciona que eles, mesmo sendo exteriores ao indivíduo, infiltrem-se nas atividades do seu cotidiano. Essa é a "intrusão de eventos distantes no cotidiano”. Para Giddens (2002), ocorre muitas vezes a inversão da realidade, de forma que aquilo que é disseminado pela mídia ganha um valor real maior do que aquilo que é experimentado pelo sujeito.

Essa intrusão pode ser relacionada com o sujeito de outra maneira. Giddens (2002) aponta que, diante da Modernidade, muitos eventos deixaram de fazer parte da experiência dos sujeitos, ocorrendo a segregação da experiência. Para o autor, "a segregação da experiência significa que, para muitas pessoas, o contato direto com eventos e situações que ligam a vida individual a questões mais amplas de moralidade e finitude são 
raras e fugazes" (GIDDENS, 2002, p. 15). Essa segregação é coordenada pela ciência, pela tecnologia e pela especialização, que alteram as condições de vida dos sujeitos, permitindo que certos tipos de experiência se tornem exteriores ao cotidiano de alguns indivíduos. Morte, doenças, etc., são experiências que com a Modernidade foram reduzidas à condição de algo privado, porém a mídia vai trazer essas experiências para o sujeito por meio do que Giddens (2002) chama de 'experiência mediada'.

Thompson (2008) aponta para uma 'visibilidade mediada'. $\mathrm{O}$ autor traz de Foucault a questão da disciplina e o modelo do Panopticon (concebido por Jeremy Bertham em 1791 e analisado por Foucault em Vigiar e Punir). Não obstante, Thompson (2008) aponta que a forma como a mídia se relaciona com o poder e a visibilidade possui certa diferença em relação a esse modelo idealista proposto por Bertham e trazido por Foucault: para o autor, enquanto no Panopticon muitos sujeitos se tornavam visíveis para poucos, na mídia poucos se tornam objeto do olhar de muitos. Além disso, na visibilidade mediada os sujeitos (aqueles que são vigiados e os que vigiam) não partilham um lugar comum, pois uma das características da mídia é a dissociação entre lugar de produção e lugar de recepção.

A mídia fornece ao sujeito novas experiências (experiências mediadas), novos sentidos de pertencimento (sociabilidade mediada), sentidos de passado (historicidade mediada) (THOMPSON, 2008); e oferece também recursos simbólicos que atuam como possibilidades para a construção de um saber sobre si. Se antes da mídia uma das formas de obter sentidos para a formação das identidades era a interação face a face, com o avanço dos meios de comunicação e da imprensa as informações passam a chegar ao sujeito através 
das mediações. Assim, "o conhecimento local é suplementado, e sempre mais substituído, por novas formas de conhecimento não locais que são fixadas num substrato material, reproduzidas tecnicamente e transmitidas pela mídia" (THOMPSON, 2008, p. 184).

Bauman (2005, p. 104) aponta então que "a mídia fornece a matéria bruta que seus leitores/espectadores usam para enfrentar a ambivalência de sua posição social"; ela disponibiliza ao sujeito informações sobre como ele deve ocupar uma posição de sujeito específica (WOODWARD, 2007).

Assim, essa mesma mídia que possibilita ao sujeito as experiências mediadas permite-lhe também o exercício do poder. para Thompson (2008, p. 26), "os meios técnicos, e as informações ou conteúdo simbólico nele armazenados, podem servir assim de fonte para o exercício de diferentes formas de poder". Ao surgirem as indústrias da mídia, surgiram também novas formas de poder, que escapam ao controle de instituições como a Igreja e o Estado.

\section{O corpo do sujeito é o sujeito?}

Caso se busque a origem histórica do corpo, encontrarse-á não apenas uma história da origem do homem, mas também a de um dualismo que atravessou os saberes sociais e atuou durante muito tempo como alicerce das distinções dos sujeitos e da sociedade. Fala-se aqui de uma origem que, de tão anterior, confunde-se com o místico e o religioso de uma época em que 
estas eram as únicas fontes de explicação para as inquietações e dúvidas dos indivíduos.

Considerando-se esses saberes, observa-se, ao ser percorrer a história, o surgimento de diversos corpos, de diferentes noções, regimes e práticas que "coexistem, rivalizam, se sucedem e se transformam ao longo do tempo" (PRADOFILHO; TRISO'T"TO, 2008, p. 116). Não se trata apenas de diversas características de um mesmo corpo, mas de vários corpos que se configuram a partir desses saberes, de um objeto que é ressignificado a partir desses discursos. Assim, para Prado Filho e Trisotto (2008, p. 116),

o corpo posto como objeto para o saber médico ao tempo de Hipócrates não é o mesmo corpo dos "fluidos" e "vapores" que se coloca para a medicina medieval, que, por sua vez, não é o mesmo da medicina moderna, na qual predomina a concepção biológica e anatomofisiológica. É importante notar que, colada a um "corpo concreto", histórico - objeto e resultado de práticas concretas encontra-se certa "corporeidade".

O corpo não é monopólio de nenhum campo de conhecimento, mesmo que em diversos momentos ele tenha sido enquadrado como natural de uma área específica (como ocorre com a medicina e a biologia). Para Prado Filho e Trisotto (2008), na Modernidade esse corpo passa por diversas formas de produção, sendo normalizado, modelado, moralizado, treinado, capacitado: "a Modernidade desenvolveu todo um conhecimento e uma sofisticada tecnologia de produção de corpos". (PRADO FILHO; TRISOTTO, 2008, p. 115). Segundo estes autores, quando transportado para uma perspectiva que considera a história e a cultura, esse corpo deixa de ser natural e passa a ser encarado como construído. 
Essa desnaturalização do corpo significa não apenas que o corpo não é natural dos campos da biologia e da medicina, mas também que são quebrados os paradigmas que o naturalizam dentro dessas áreas.

O corpo, este volume concreto, não tem nada de natural - em rigor, não existe "corpo natural", espontâneo e livre, "pura potência", anterior a qualquer trabalho da cultura - ele é sempre resultado de investimentos de poder e de enunciações por saberes: sua própria "natureza" é construída (PRADO FILHO; TRISOTTO, 2008, p. 116).

Dentro dessa relação entre corpo e historicidade e cultura, Prado Filho e Trisotto (2008) indicam a existência de um corpo e de uma corporeidade: o corpo como um objeto concreto, histórico, objeto das práticas; a corporeidade como "a ordem dos dispositivos, dos enunciados e das normas, implicando jogos de enunciação, normalização e de subjetivação, nos quais não apenas o corpo, mas a própria 'alma', a subjetividade dos sujeitos, é produzida" (PRADO FILHO; TRISOT'TO, 2008, p. 116; CODO; SENNE, 2004).

Para Prado Filho e Trisotto (2008), o sujeito só tem acesso ao corpo pela corporeidade, pelos enunciados e práticas. É a partir dessa corporeidade que os sujeitos (dos sujeitos do cotidiano até os especializados) se relacionam com o corpo.

Qual seria, então, a relação entre a subjetividade desse sujeito e o seu corpo?

Para Woodward (2007), o corpo é o lugar em que o indivíduo estabelece fronteiras definidoras de sua identidade, e na perspectiva da psicanálise lacaniana, o primeiro passo para a construção de um sentido de "eu" pelo sujeito; ele é um referencial 
estável para a autocompreensão do sujeito, um significante de sua subjetividade (HALL, 2007).

A relação entre a identidade (uma convenção social) e o corpo do indivíduo é que esse eu não é uma mera projeção, mas ele é encarnado e se configura como um espaço simbólico na formação das identidades (GIDDENS, 2002). Para Castro e Bueno (2005, p. 9), "num mundo marcado pela desterritorialização, o corpo desponta como um espaço limite de vivência (ou até mesmo sobrevivência) do exercício da territorialidade". Ele é, então, território da cultura (uma vez que se configura como um suporte para a cultura das sociedades) e da identidade (CASTRO; BUENO, 2005; GUIMARÃES, 2005).

Para Guimarães (2005, p. 80), a globalização e a luta entre o individual e o coletivo ganham no corpo um espaço para "o embate entre o individuo e os interesses políticos e econômicos que querem incluí-lo nesse processo". O autor afirma o corpo como o aspecto máximo da individualização (uma vez que há apenas um corpo para cada indivíduo e um indivíduo para cada corpo), porém ele é coletivizado à medida que passa a carregar o simbólico gerado pela globalização.

Dentro do processo de ressignificação e deslocamento da cultura diante da globalização, observa-se o próprio corpo como um lugar de comunicação (GUIMARÃES, 2005), como algo usado para expressar ideias - cabendo para isso só a utilização não das roupas e dos acessórios, mas também de elementos como os gestos, o comportamento do sujeito e práticas como o body building, a tatuagem e o piercing. Dessa forma, o corpo se torna o que Ramos (2005) denomina de 'território'.

O corpo é então espaço para a inscrição do pertencimento, é lugar em que ocorre a batalha dos processos de identificação. 
Corpo, identidade e cultura se ligam e se apoiam, e a reflexividade da identidade do sujeito se estende ao corpo (GIDDENS, 2002).

A partir do século XX, com o apagamento da divisão entre corpo e alma, modifica-se a relação do indivíduo com o seu corpo, surgindo uma perspectiva do corpo como objeto na história das mentalidades, conforme observa Courtine (2008) a partir da teoria foucaultiana.

Ory (2008) expõe que "o ordinário dos corpos humanos se acha, por definição - entenda-se, por delimitação -, submetido à influencia do movimento geral das sociedades". O que é então apontado pelo autor é um ordinário que se constrói a partir de uma perspectiva histórica e social. Segundo ele, as modificações e movimentos da cultura provocados na Modernidade pela globalização afetam as representações e práticas corporais. Surgem dessa forma modernizações como as mudanças nos sistemas de água e esgoto e o desenvolvimento de políticas públicas que limitam o tempo de trabalho do indivíduo e permitem uma mudança no estilo de vida das populações - mudanças essas que passam pela medicina, pela sexualidade e pela corpolatria.

Foucault (2005, 2008a, 2008b, 2009) aponta para um corpo sobre o qual recai o poder. Para o autor, a consciência do indivíduo sobre o próprio corpo só se deu devido a um investimento no corpo pelo poder (FOUCAULT, 2008b, p. 149): "é a partir de um poder sobre o corpo que foi possível um saber fisiológico, orgânico".

Para Foucault (2008a), o poder se exerce nas ações cotidianas, e é no cotidiano do corpo que ele estará presente. O corpo, segundo o filósofo, só é útil na medida em que é produtivo e dócil, passível de transformação e aperfeiçoamento, um corpo 
ativo atingido pelo poder: "esses métodos que permitem o controle minucioso das operações do corpo, que realizam a sujeição constante de suas forças e lhes impõem uma relação de docilidade-utidade, são o que podemos chamar as 'disciplinas". (FOUCAULT, 2008a, p. 118).

De acordo com Revel (2005, p. 35), as disciplinas são "técnicas de coerção que exercem um esquadrinhamento sistemático do tempo, do espaço e do movimento dos indivíduos e que atingem particularmente as atividades, os gestos, os corpos". Elas atuam com o domínio do corpo, fabricam corpos submissos e exercitados, corpos dóceis (FOUCAULT, 2008a). Se por um lado elas possibilitam que o corpo seja o mais útil possível, potencializando-o, por outro também diminuem as suas forças, na medida em que o tornam submisso e obediente. Ele é individualizado por seu posicionamento, sua localização, sua distribuição, e hierarquizado. Ao fabricar o indivíduo, a disciplina o coloca tanto como objeto quanto como instrumento de seu exercício. Ela se exerce por meio de um mecanismo que possua um "jogo do olhar", um aparelho de observação do indivíduo, assim como de registro e treinamento. (FOUCAULT, 2008a).

Para Foucault (FOUCAULT, 2008a, p. 148), o ato de vigiar é um importante fator de controle, pois

a disciplina faz "funcionar" um poder relacional que se auto-sustenta por seus próprios mecanismos e substitui o brilho das manifestações pelo jogo ininterrupto dos olhares calculados. Graças às técnicas de vigilância, a "física" do poder, o domínio sobre o corpo se efetua segundo as leis da ótica e da mecânica, segundo um jogo de espaços, de linhas, de telas, de feixes, de graus, e sem recurso, pelo menos em princípio, ao excesso, à força, à violência.

Assim, a punição não se dá pela força, mas pelo olhar (olhar que, na sociedade moderna, é realizado também 
pela mídia e recai sobre o corpo do sujeito). O que foge ao adequado, ao apontado pela disciplina como "normal é penalizado (FOUCAULT, 2008a). A punição atua de forma a reduzir os desvios. A classificação e a hierarquização castigam e recompensam: "a disciplina recompensa unicamente pelo jogo das promoções que permitem hierarquias e lugares; pune rebaixando e degradando" (FOUCAULT, 2008a, p. 151), caracterizando-se, dessa forma, uma punição que não tem em si a função de reprimir, uma vez que é ela mesma uma das formas de controle da disciplina.

Recai ainda sobre os corpos o biopoder, que "age sobre a espécie humana, que considera o conjunto, com o objetivo de assegurar a sua existência" (MACHADO, 2008, p. XXII). Faz parte do biopoder o controle sobre a natalidade e a mortalidade, sobre as condições de vida do indivíduo um poder que atua no "nível da espécie, da população com o objetivo de gerir a vida do corpo social". (MACHADO, 2008, p. XXII). Essa biopolítica se ocupa da gestão de elementos da vida dos indivíduos como a saúde, a higiene, a alimentação, a sexualidade e outros, tornando esses fatores algo da ordem da preocupação política (REVEL, 2005). O ideal de poder consiste em garantir a vida do sujeito, o que ocorre principalmente através do dispositivo da sexualidade. Neste sentido, observa-se - como analisa o autor - a relação desse tipo de poder com o capitalismo, que introduziu o corpo dos sujeitos nos aparelhos de produção, fazendo com que seus corpos fossem valorizados (FOUCAULT, 2009).

Enquanto a disciplina atua no nível do individual, o biopoder dar-se-á em relação ao corpo da população, ao nível da espécie, do ser vivo. A biopolítica volta-se para a população através de mecanismos reguladores que visam estabelecer e 
manter o equilíbrio dessa população, de forma que a vida seja otimizada. Enquanto a disciplina é centrada no corpo, produz individualidades e dociliza, o biopoder foca a vida, na tentativa de controlar, prevenir e remediar eventos aleatórios que possam surgir. Uma vez que esses mecanismos atuam em níveis diferenciados no corpo do indivíduo e na vida da população), eles não se anulam, ao contrário, articulam-se, tendo em comum a norma (FOUCAULT, 2005).

\section{Por fim, que sujeito é esse?}

Diante dessas concepções de modernidade, identidade, mídia e corpo, lançou-se um olhar sobre doze enunciados verbais e não verbais retirados de seis revistas de circulação, público, temática e periodicidade diferenciados: Boa Forma, Capricho, Men's Health, Saúde é Vital, Veja e Época:

- Capa. Revista Veja, Edição 2139, ano 42, número 46. 18 de novembro de 2009.

- Capa. Revista da Semana, Edição 78, ano 3, número 9. 12 de março de 2009.

- Capa. Revista Veja, Edição 1792, ano 39, número 9. 05 de março de 2003.

- A medicina revela a mulber de verdade. Revista Veja, Edição 1998, ano 40, número 9. 07 de março de 2007.

- Rápido e total: trabalhe o corpo todo com apenas um movimento. Revista Men's Health, Edição 36, ano 3, número 12. Abril de 2009. 
- Aposta dupla: para manter o corpão, ele faz exercícios em casa e na academia. Revista Men's Health, Edição 36, ano 3, número 12. Abril de 2009.

- Ganhe o corpo que elas desejam. Revista Men's Health, Edição 36, ano 3, número 12. Abril de 2009.

- De corpo inteiro. Revista Saúde é vital, número 269. Janeiro de 2006.

- Porque elas querem ser tão magras? Época, Edição número 432. 28 de agosto de 2006.

- Capa. Revista da Semana, Edição 45, ano 2, número 27. 17 de julho de 2008.

- Eu tinha vergonha do meu corpo. Revista Boa Forma, Edição 206, ano 19, número 8. Agosto de 2004.

- Eu odeio o meu corpo. Revista Capricho, Edição 1062. 18 de janeiro de 2009.

As materialidades discursivas foram analisadas mediante um batimento descritivo-interpretativo - tanto em seus aspectos verbais quando nos imagéticos -, por meio do qual foi possível encontrar certas regularidades. Pôde-se verificar o corpo como uma construção discursiva produzida pela mídia conforme as relações de saber e poder articuladas no histórico e no social. Assim, o corpo não preexiste; ele é configurado a partir do discurso, é criado no acontecimento e na sua objetivação pelos saberes. Nesta perspectiva, a subjetivação do sujeito só vai ocorrer a partir da objetivação do seu corpo.

O corpo aparece controlado por fatores como a genética, o body building do treino, a estética e a ciência. O poder recai sobre ele em diversos níveis, seja por meio dos 
micropoderes e biopoderes do cotidiano que induzem o sujeito à mudanças na alimentação e à prática de técnicas corporais que mantenham a sua performance e a sua capacidade de reprodução, seja por intervenções mais drásticas que regulam a sua existência e constituição como corpo, seja ainda por sua codificação genética, que uniformiza os sujeitos dentro de uma mesma espécie biológica e diferencia o corpo normal do anormal.

A corpolatria (o culto ao corpo) passa pelo treino, pela sexualidade, pela estética e pela medicina, promovendo mudanças que fazem o corpo enquadrar-se em uma ordem discursiva segundo a qual ele deve ser magro (a gordura é tida como doença de âmbito da população que torna o sujeito improdutivo e não garante o seu bem-viver, devendo então ser combatida pelas instituições promotoras de formas simbólicas e saberes como a mídia e a medicina, a família e o próprio Governo), fortalecido, bem-modelado (pois se a gordura é sinal de doença, o excesso da magreza também o é), belo e jovem. A sua sexualidade pode ser escondida ou mostrada, a depender de fatores como a posição-sujeito ocupada pelos sujeitos. Observou-se que nos enunciados direcionados ao público feminino o apelo à beleza dá-se por meio dos sentimentos de confiança e autoaceitação, enquanto naqueles direcionados ao público masculino o culto ao corpo ocorre principalmente para adquirir força e tornar-se sexualmente atrativo. É com essa imagem de corpo transmitida pela mídia que o sujeito irá se identificar, e não com aquela que é a sua própria (BAUMAN, 2001). Há então uma 'corporeidade mediada' (termo aqui proposto), pela qual o sujeito passa a ter noção do próprio corpo a partir dos exemplos fornecidos pela mídia por meio das formas simbólicas. 
O desnudamento dos corpos é um fator a ser considerado. Se antes essa prática e a perda do pudor tornaram possível o surgimento do culto ao corpo, na Modernidade ocorre uma inversão de valores, ou seja, o corpo se mostra justamente para evidenciar suas formas. Essa nova ordem torna possível observar o funcionamento dos processos de docilização do corpo. Diante da mudança das formas de punição e controle operadas durante a Idade Média, o olhar assumiu um papel fundamental, e é este dispositivo que atua através da exposição do corpo, tornando possível assim o seu controle por meio de uma moderna e complexa modalidade de Panopticon que mantém o seu funcionamento também por meio da mídia.

Os enunciados que representam o corpo e o sujeito na mídia constroem o efeito de sentido de que a magreza e o corpo ideal podem ser construídos, principalmente, por meio do fitness. Há aqui algo a ser notado: enquanto a ciência estipula e delimita o corpo, o treino o modifica. Se não há o discurso da modificação, há o da aceitação limitada - limitada porque ela se dá a partir de uma gradação em que o corpo pode ser mais ou menos adequado, mas nunca estar fora da ordem e da norma constituída pelo saber e licenciada pelo poder.

A ciência assume um lugar autorizado e legitimado para enunciar sobre o corpo, uma vez que este não preexiste ao discurso. Essa tomada de posição da ciência pode ser vista por meio da presença constante da voz dos especialistas de diferentes áreas (genética, psicologia, nutrição, fisiologia, medicina) presentes nos enunciados.

No nível da construção dos enunciados o controle aparece em forma de quantificação e de mesura. Cada 
movimento do corpo é cultural, faz parte do saber e é sancionado pelo poder; a forma como o sujeito utiliza o seu próprio corpo e dispõe do corpo do outro, com ou sem o uso de instrumentos, está condicionada e regulamentada pelas relações de saber e poder.

Faz parte dessa mesma mídia, na condição de meio de comunicação de massa, a dissociação entre a produção e a recepção das formas simbólicas, na qual não há dialogismo entre os interlocutores ou um feedback instantâneo do leitor. Apesar disso, nos enunciados é possível notar uma tentativa de apagamento dessa separação, promovendo uma aproximação do enunciador com o sujeito-leitor. Assim, o leitor é a todo o momento convidado a assumir uma posição de segunda pessoa do discurso, seja por meio dos verbos no modo imperativo seja por seu uso pronominal. Há também a tentativa de angariar a confiança desse indivíduo, fator que contribui para a instauração de um efeito de verdade nos enunciados. Esse efeito de verdade ocorre também pela utilização recorrente do discurso dos especialistas, lugares autorizados de enunciação.

Diante desses aspectos, o corpo se constitui não só como lugar de conflito e disputas dos saberes e discursos, mas também como um conflito do sujeito com o próprio corpo: ora ele o cultua, ora o nega e segrega; ora se apropria do outro, ora é apropriado por esse outro. É nesse jogo que se dá o processo de subjetivação do sujeito e este é chamado a assumir uma posição.

Assim sendo, estudar o sujeito no viés da mídia possibilita o entendimento dessa mediação e subjetivação e torna-se fundamental caso se tenha em vista a descoberta do homem moderno e atual, uma vez que a própria mídia é um importante instrumento das tendências modernizantes. 


\section{Referências}

BAUMAN, Z. Modernidade líquida. Rio de Janeiro: Jorge Zahar, 2001.

Identidade: entrevista a Benedetto Vecchi. Rio de Janeiro: Jorge

Zahar, 2005.

BROWN, P. Corpo e sociedade: o homem, a mulher e a renúncia sexual no início do cristianismo. Rio de Janeiro: Jorge Zahar, 1990.

CASTRO, A. L. de; BUENO, M. L. Introdução. In: BUENO, M. L.;

CASTRO, A. L. de (Orgs.). Corpo, território da cultura. São Paulo: Annablume, 2005, p. 9-10.

COURTINE, J.-J. Introdução. In: CORBIN, A.; COURTINE, J.-J.;

VIGARELLO, G. (Dir.). História do corpo: as mutações do olhar. O século XX. Vol.3. Petrópolis: Vozes, 2008a, p. 7-12.

FOUCAULT, M. Em defesa da sociedade: curso no Collège de France (19751976). São Paulo: Martins Fontes, 2005.

. Vigiar e punir: nascimento da prisão. 35. ed. Petrópolis: Vozes, 2008a.

Microfísica do poder. 26. ed., Rio de Janeiro: Edições Graal, 2008b.

História da sexualidade: a vontade de saber. Vol. 1. 19 ed. Rio de

Janeiro: Graal, 2009.

GIDDENS, A. Modernidade e identidade. Tradução Plínio Dentzien. Rio de Janeiro: Jorge Zahar, 2002.

GUIMARÃES, M. E. A. Globalização: o corpo como campo de batalha. In: BUENO, M. L.; CASTRO, A. L. de (Orgs.). Corpo, território da cultura. São Paulo: Annablume, 2005, p. 75-87.

HALL, S. Quem precisa de identidade? In: SILVA, T. T. da. (Org.). Identidade e diferença: a perspectiva dos estudos culturais. 7. ed. Petrópolis: Vozes, 2007, p. 103-133. 
ORY, P. O corpo ordinário. In: CORBIN, A.; COURTINE, J.-J.;

VIGARELLO, G. (Dir.). História do corpo: as mutações do olhar. O século XX. Vol.3. Petrópolis: Vozes, 2008, p. 155-195.

PRADO FILHO, K.; TRISOT'TO, S. O corpo problematizado de uma perspectiva histórico-política. Psicologia em Estudo, Maringá, v. 13, n. 1, p. 115121, jan./mar. 2008.

REVEL, J. Foucault. conceitos essenciais. São Carlos: Claraluz, 2005.

SILVA, T. T. da. A produção social de identidade e da diferença. In: (Org.). Identidade e diferença: a perspectiva dos estudos culturais. 7. ed. Petrópolis: Vozes, 2007, p. 73-102.

THOMPSON, J. B. A mídia e a Modernidade: uma teoria social da mídia. 9. ed. Petrópolis: Vozes, 2008.

WOODWARD, K. Identidade e diferença: uma introdução teórica e conceitual. In: SILVA, T. T. da (Org.). Identidade e diferença: a perspectiva dos estudos culturais. 7. ed. Petrópolis: Vozes, 2007, p.7-72. 



\section{DISCURSO E BIOPOLÍTICA NA SOCIEDADE DE CONTROLE}

Kátia Menezes de Sousa ${ }^{7}$

A arqueologia de Michel Foucault é uma modalidade de análise do discurso. Conforme o autor (1995), o discurso é constituído por um conjunto de sequências de signos enquanto enunciados, isto é, enquanto se lhes possam atribuir modalidades particulares de existência por terem sido efetivamente produzidas. $\mathrm{O}$ enunciado se refere ao que realmente pôde ser dito; é constituído por uma materialidade que lhe dá substância, suporte, lugar e uma temporalidade que lhe asseguram uma identidade. Além disso, possui um valor que caracteriza o lugar em que aparece, a sua capacidade de circulação e de troca, sua possibilidade de transformação na administração de seus raros recursos e de sua pobreza enunciativa. Soma-se a isso o fato de que o enunciado porta uma exterioridade paradoxal e formas de acúmulo que garantem os jogos da memória e do esquecimento. É por isto que o discurso, assim concebido,

aparece como um bem - finito, limitado, desejável, útil - que tem suas regras de aparecimento e também suas condições de apropriação e de utilização; um bem que coloca [...] a questão do poder, um bem que é, por natureza, o objeto de uma luta, e de uma luta política (FOUCAULT, 1995, p. 139).

7 Professora da Faculdade de Letras e do Programa de Pós-Graduação em Letras e Linguística da Universidade Federal de Goiás. 
$\mathrm{Na}$ atualidade, a análise da circulação e da troca de enunciados no campo midiático permite descrever os discursos que constituem a prática política e o tipo de sociedade produzido pela rede enunciativa tecida nos diferentes sistemas de formação dos discursos. Essa relação é possível porque os dispositivos midiáticos trabalham para ter o controle sobre esse bem, que é o discurso, atuando ativamente nos processos de identificação dos sujeitos de uma sociedade. A mídia, em todos os seus segmentos, participa da construção política do país, promovendo o (des) encontro entre o discurso da população e o discurso dos governos. Assim, os discursos veiculados, sustentados, descartados, ou mesmo silenciados pela mídia, constituem o arquivo que define, nos termos de Foucault (1995), o sistema de enunciabilidade, de formação e transformação dos enunciados, bem como a lei do que pode ser dito. Se o que é dito o é no interior das regras do arquivo, sua análise comporta, conforme Foucault (1995), a orla do tempo que cerca nosso presente o domina e o indica em sua alteridade, instaura o corte que nos separa do que não podemos mais dizer e do que fica fora de nossa prática discursiva. As fronteiras das formações discursivas que margeiam os enunciados políticos e os cortes que definem a existência de certos discursos limitam seu intercâmbio, sua comunicação e sua apropriação, o que justifica a análise dos enunciados midiáticos numa sociedade que luta para ter o controle e, paradoxalmente, é contra ele.

Assim, neste trabalhopretende-seanalisaralguns enunciados que conferem forma de existência aos discursos políticos na atualidade brasileira, dando-lhes tratamento de arquivo, ou seja, "uma existência acumulada dos discursos" (FOUCAULT, 2000, p.72), por meio da veiculação de campanhas sociais dos governos. O recorte requerido por esta curta reflexão se liga à elaboração de Michel Foucault acerca da sociedade de controle que começa a se 
desenhar no século XVIII, com o aparecimento de um poder que é ao mesmo tempo disciplinador e normalizador e não se exerce mais sobre os corpos individualizados, mas se concentra na figura do Estado, em que é exercido com pretensões de administrar a vida e o corpo da população. No texto "A governamentalidade", parte de uma aula ministrada em 1978, Foucault (2003) explica que, após o século XVIII, a arte de governar ligou-se à emergência da expansão demográfica, e seus objetivos passaram a ser melhorar o destino das populações, aumentar a duração de sua vida e melhorar sua saúde. Os instrumentos utilizados para alcançar esses objetivos se centrarão essencialmente na própria população, sobre a qual o governo age diretamente, fazendo campanhas, ou indiretamente, estimulando, sem que as pessoas o percebam, a taxa de natalidade, ou dirigindo os fluxos populacionais para certas regiões e para dadas atividades.

Nesse sentido, é fácil perceber que na atualidade as campanhas governamentais se aprimoraram e se constituem em um eficiente meio de esclarecer e conscientizar sobre o que o governo faz e o que a população cobra e espera. As campanhas retratam a forma de governar, as vozes suplicantes da população e os problemas advindos da rapidez e globalização da circulação das informações, dos problemas que retornam e dos que persistem em continuar estampados nos enunciados dos diferentes campos do saber.

Numa conferência proferida no Rio de Janeiro em 1974, publicada em Microfísica do poder, Foucault (2003) levanta a hipótese de que o capitalismo socializou um primeiro objeto, que foi o corpo enquanto força de produção, e de que o controle da sociedade sobre os indivíduos não se operava simplesmente pela consciência ou pela ideologia, mas começava no corpo e com o corpo. Conclui afirmando que a sociedade capitalista investiu 
no biológico, no somático, no corporal, pois o corpo é uma realidade biopolítica, e a medicina, uma estratégia biopolítica. Mesmo por uma investigação despretensiosa, desde que de caráter científico, é possível perceber que os enunciados que compõem as plataformas políticas ou a interação dos governos com a população referem-se, sob vários aspectos, ao interior e ao exterior dos corpos das pessoas, para a garantia de saúde, bemestar, beleza e longevidade.

Em 1976 Foucault desenvolveu o conceito de biopolítica em História da sexualidade I: a vontade de saber, e nas aulas ministradas no Collège de France, publicadas mais tarde na obra Em defesa da sociedade, considerando esse conceito no interior de uma estratégia mais ampla, que ele denominou de biopoder. Conforme Foucault (2001), o biopoder sucede o poder de soberania, mantendo a relação vida/morte. Enquanto para o soberano a máxima era fazer morrer e deixar viver, para o biopoder a ordem é fazer viver e deixar morrer. A partir do século XIX a lógica deixa de ser a da soberania e passa a ser a lógica biológica. O "fazer viver" a que se refere Foucault (1999), segundo Pelbart (2003), marca o biopoder e se constitui de duas formas: como disciplina e como biopolítica. As disciplinas, baseadas no adestramento do corpo, na otimização de suas forças, na sua integração em sistemas de controle, tomam o corpo como máquina, sujeito, assim, a uma anatomopolítica. A biopolítica mobiliza outro componente estratégico, que é a gestão da vida incidir não mais sobre os indivíduos, mas sobre a população enquanto espécie. Aqui o corpo é atravessado pela mecânica do vivente, como suporte de processos biológicos. Trata-se da biopolítica da população, em que a ênfase recai sobre nascimento e mortalidade e sobre o nível de saúde e a longevidade. 
Instaura-se, assim, uma tecnologia de duas faces, a qual, na leitura de Pelbart (2003), caracteriza-se, de um lado, pelo biopoder - que se realiza por intermédio das disciplinas, das regulações e da anatomopolítica do corpo -, e por outro, pela biopolítica da população - por meio da espécie, das 'performances' do corpo e dos processos da vida. Ao lado da submissão dos corpos através das escolas, quartéis e fábricas, surgem os problemas de natalidade, longevidade, saúde pública, habitação e imigração.

Apesar de ter formulado tais conceitos ainda nos anos de 1970, o legado da reflexão de Foucault, conforme analisa Duarte (2008), vinte anos depois dissemina idéias e renova campos distintos da investigação das Ciências Humanas, promovendo a formulação de novos problemas e novas possibilidades de análise. $\mathrm{Na}$ atualidade, os conceitos de biopoder e biopolítica ganham importância capital nas análises dos problemas políticos e sociais.

Realçando sua relevância, Hardt e Negri (2004) consideram que a obra de Foucault permite reconhecer uma transição histórica e de época das formas sociais da sociedade disciplinar para a sociedade de controle. A sociedade disciplinar é aquela na qual o comando social é construído mediante uma rede dispersa de dispositivos que produzem e regulam os costumes, os hábitos e as práticas produtivas. Por meio de instituições disciplinares (prisão, fábrica, hospital, escola, universidade) que fornecem explicações lógicas para a razão da disciplina, essa sociedade põe para funcionar mecanismos de inclusão e de exclusão. A sociedade de controle desenvolve mecanismos cada vez mais democráticos, distribuídos pelos corpos (em sistemas de bem-estar, atividades monitoradas) e cérebros (em sistemas de comunicação, redes de informação) dos cidadãos. Essa sociedade pode ser caracterizada pela intensificação e síntese dos aparelhos de normalização e 
de disciplinarização. Exemplo disto é a ditadura do bem-estar, da beleza; é a obrigatoriedade de ser feliz segundo padrões já testados e definidos.

Acompanhando essa modernização dos mecanismos disciplinares, Foucault (2001) analisa que a hipótese da repressão cedeu lugar ao biopoder. $\mathrm{Na}$ concepção da hipótese repressiva, segundo Rabinow e Dreyfus (1995), há a ideia de que a resistência à repressão seria uma batalha importante e de que a voz transgressora desafiaria o poder repressivo, pois a oportunidade "de falar contra os poderes, dizer a verdade e prometer prazer; ligar entre si a iluminação, a libertação e volúpias múltiplas; manter um discurso onde se juntam o ardor do saber, a vontade de mudar a lei e o jardim esperado de delícias" (FOUCAULT, 2001, p.13) seria a forma de restabelecer a verdade distorcida pelo poder. Pode-se refletir, com base no biopoder, que a hipótese da repressão e a busca por vencê-la possibilitaram a construção de estratégias mais sutis e eficazes para o exercício do poder.

Conforme Foucault (2001), seria necessário falar de biopoder para designar aquilo que faz entrar a vida e seus mecanismos no domínio dos cálculos explícitos e torna o podersaber um agente de transformação da vida humana. Nisto se vê a preocupação com o bem-estar em termos de necessidade e felicidade das pessoas e com novas técnicas para maximizar a vida. Analisando os dispositivos midiáticos, Hardt e Negri (2004) explicam que a comunicação de massa expressa o movimento de globalização e controla o sentido de direção do imaginário que percorre essas conexões comunicativas, ou seja, o imaginário é guiado e canalizado dentro da máquina de comunicação. O poder, enquanto produz, organiza, e enquanto organiza, fala e se expressa como autoridade. A linguagem, à medida que comunica, 
produz mercadorias, mas, além disso, cria subjetividades, põe umas em relação às outras e as ordena.

A trajetória analítica de Foucault possibilita dizer que a questão da vida atravessa toda a sua obra, visto que ele a problematiza em vários ângulos. Portocarrero (2008) pensa da mesma forma e argumenta que essa problematização se deu primeiro por meio das análises das formas de objetivação do sujeito, de um lado, pela via da pesquisa arqueológica das condições de possibilidade da existência de saberes empíricos que propiciaram a constituição das ciências humanas tendo a vida e o homem como objetos, e por outro, pela via da genealogia dos poderes. Também afirma que as ciências biológicas se articulam com outros campos de saber e de práticas e com as relações de forças que incidem sobre a vida dos indivíduos. Em segundo lugar, a problematização da vida ocorre em suas análises das formas de subjetivação, com a hipótese de que a ética exige a visão da vida como obra de arte, sendo o cuidado de si a possibilidade de transformar o ser mesmo do sujeito para ter acesso à verdade e estabelecer para si um modo de vida ético, belo e heroico.

Inserida nessa trajetória, a noção de biopolítica é formulada por Foucault (2001) para demonstrar que o poder passa a ser exercido por meio de controles precisos e regulações de conjunto e mecanismos de segurança, como forma de exigir mais vida e de aumentar e gerir essa vida. A constituição da biopolítica só é possível no contexto da invenção da vida biológica, da entrada da vida nas ideias e práticas políticas. Num sentido mais amplo, o biopoder é uma forma de normalizar a própria conduta da espécie, de regrar, manipular, incentivar e observar macrofenômenos como as taxas de natalidade e mortalidade, as condições sanitárias das cidades, o fluxo das infecções e contaminações, a duração e as condições da vida. As tecnologias do biopoder e os 
saberes investidos nessas tecnologias produzem as categorias de anormalidade (delinquente, perverso, doente etc.) com base no par normal e anormal, e constroem formas para eliminá-las.

Nas campanhas estatais e nas produzidas pela mídia constata-se a preocupação com questões que emergem em torno de temas como tabagismo, alcoolismo, trânsito e álcool, aborto, gravidez precoce, obesidade, saúde, violência, preservação do meio ambiente, os quais incidem sobre o corpo e a vida das pessoas, normalizando práticas e atitudes e excluindo aqueles que não passem pela aferição da normalidade.

Nesse sentido, as campanhas visam à preservação e à intensificação da vida daquele que é construído como normal (o vencedor) e à eliminação - e não só à derrota - daqueles tidos como anormais, que são inimigos não mais como opositores políticos, mas como entidades biológicas. Foucault (1999, p. 305) considerou essa batalha entre o que deve viver e o que deve morrer quando afirmou: "A morte do outro não é simplesmente a minha vida, na medida em que seria minha segurança pessoal; a morte do outro, a morte da raça ruim, da raça inferior (ou do degenerado, ou do anormal) é o que vai deixar a vida em geral mais sadia, mais sadia e pura."

$\mathrm{Na}$ análise de Duarte (2008), essa tese constitui um dos legados de Foucault para o futuro, pois a noção de biopolítica e o caráter contraditório do biopoder permitem compreender a vida política contemporânea como traçada na raridade dos enunciados acumulados que, de forma calculada e administrada, tanto produzem e incentivam a viver quanto impõem a morte a quem resista a entrar na escala da normalidade. Neste sentido, a manutenção da qualidade de vida de uns implica e exige a destruição da vida de outros; o poder traça a partilha entre a vida 
que merece viver e aquela que pode ser exterminada; instaura o corte entre a vida protegida e a vida abandonada e relegada à esfera marginal que fica fora do núcleo da comunidade política, a qual, estando banida, pode ser capturada e morta. É assim que se podem analisar essas relações nas campanhas estatais: alguns devem morrer para se tornarem estatísticas calculadas pelo poder-saber e reinscritas como agentes de transformação da vida para o convencimento de outros que devem viver.

Assim, a vida da população é regrada por enunciados que invadem todos os espaços da convivência social. As proibições aumentam a cada dia em conformidade com o desejo de viver mais e melhor, dentro de padrões estabelecidos pelos saberes e em conformidade com os problemas advindos das inovações científicas e tecnológicas. O biopoder é exercido de forma sutil, quase imperceptível, e produz comportamentos que o propagam e que aguardam por técnicas mais eficientes em garantir a vida. Produz, também, os culpados, os indolentes, que não quiseram perceber que a ciência, as novas tecnologias, os governos e a mídia investem na divulgação de saberes cujo objetivo é apenas melhorar e prolongar a vida da população. Desta forma, o poder estatal tem na própria população uma grande aliada no seu afã de garantir o sucesso de suas propagandas e promover a "caça às bruxas" que teimam em contaminar os normais. Produz-se a política da intransigência para com os que se negam a passar pela purificação. É o que se vê nas campanhas voltadas aos cuidados com a forma física e com a alimentação, à erradicação dos vícios, ao controle das atividades sexuais, à violência urbana, etc.

Em uma entrevista publicada em 1977 em Microfísica do poder, intitulada "Não ao sexo rei", Foucault (2003) esclarece que o discurso da liberação sexual promovido pelos sexólogos colocava uma armadilha perigosa, pois funcionava como um 
instrumento de controle e de poder ao utilizar o que as pessoas diziam, sentiam ou esperavam. Esse tipo de discurso explora a tentação de acreditar que, para ser feliz, basta ultrapassar o umbral do discurso e eliminar algumas proibições. Além disso, acaba depreciando e esquadrinhando os movimentos de revolta e liberação e produzindo uma forma de proibição ainda mais eficiente: a ordem do discurso. Em suas elaborações sobre o biopoder Foucault esteve alerta a essa ordem para evidenciar que as políticas higienistas e saneadoras levam a população a louvar o espírito humanitário das intervenções políticas que visam a incentivá-la, protegê-la, estimular e administrar a sua vida, e a não perceber a contrapartida brutal dessa obsessão do poder estatal pelo cuidado purificador da vida. Mesmo tendo a vida se constituído no elemento político que precisa ser normalizado, a violência não foi controlada, pois tal cuidado com a vida traz a exigência contínua da morte em massa, já que é no contraponto da violência purificada que se podem garantir melhores formas de sobrevivência a uma dada população.

Dessa forma, o biológico, ao incidir sobre o político, faz com que o poder já não se exerça sobre sujeitos de direito, cujo limite é a morte, mas sobre seres vivos, de cuja vida o poder deve se encarregar. Conforme Foucault (2001, p. 136), "foi a vida, muito mais do que o direito, que se tornou o objeto das lutas políticas, ainda que estas últimas se formulem através da afirmação de direito”. É a vida que também norteará a história da linguística como uma saída para o caráter prescritivo e sistematizado da língua, que não a contemplava em sua exterioridade e em sua manifestação opaca e diferenciada e decretava, como um soberano, a morte daquilo que escapava à normatividade e ao sistema. A saída para a garantia do exercício do poder, da mesma forma que em outras formações discursivas, era deixar viver a língua 
em suas manifestações, mas fazê-lo utilizando-se de formas de higienização justificadas pelo caráter humanitário que invadirá as relações humanas. $\mathrm{O}$ poder político passa, principalmente, pelas concepções de língua, e atribui a esta um caráter conforme com suas estratégias para governar.

Gadet e Pêcheux (2004), para situar o discurso na história da linguística, traçam um paralelo entre o direito e a vida para demonstrar a linha - ora pendular, ora espiral - que será seguida pela linguística entre o pensamento lógico e os ideais sociológicos. Argumentam que a lógica garante o exercício do direito numa ditadura que assegura a disjunção entre o lícito e o criminoso, o legítimo e o ilegítimo, o válido e o não válido, o verificável e o falso. Essa lógica ancora-se, conforme os autores, na escrita lógico-matemática. A noção de vida, de caráter biológico, estende uma rede descritiva sobre a diversidade das línguas e dialetos para mostrar o conjunto de suas diferenças, fazendo com que a linguística construa sua versão funcionalista como ferramenta para resolver os problemas sociais. Analisando a Modernidade capitalista, os referidos autores (p. 116) assim se expressam:

[...] marcada pela lógica da administração (a língua de madeira do Estado) e pela "língua de vento" da propaganda, [é] que a linguagem foi instituída como "instrumento de comunicação"... dissimulando pela noção higiênica da informação o fato de que o que se comunica provém de uma loucura do Estado: a era dos comunicados é, ao mesmo tempo, a da comunicação das ordens e da dos delírios comunicados.

O sociobiologismo, conforme Gadet e Pêcheux, tem seu desenvolvimento marcado pelas técnicas de higienização da língua e acaba alcançando o que hoje se conhece como o politicamente correto, que serve aos interesses do biopoder para disseminar as ideias da qualidade de vida em suas várias esferas. Como integrante da política da vida, o politicamente correto 
classifica e identifica as pessoas incluindo-as numa normalidade forjada e excluindo o que pretendia incluir. No processo de democratização das práticas sociais e da língua como instrumento, a padronização será exigida não pelo viés autoritário das leis e regras do Direito ou das gramáticas, mas pelo viés da necessidade difundida de se ter qualidade de vida, acesso a mecanismos que possam garantir o prolongamento da vida e o direito de ocupar o lugar do diferente, mas de uma diferença que é justificada e categorizada por contextos sociais e culturais. A relação causal entre contexto e linguagem, contexto e atitudes e contexto e comportamento produz outra espécie de classe, que não pode ser excluída, mas pode ser instigada a ocupar o lugar dos bemsucedidos, dos saudáveis física e emocionalmente, dos belos, dos conectados nas informações - dos felizes, enfim.

Como a língua é o lugar da falha, do ambíguo, que nem a lógica nem a sociologia - em parceria com a biologia, a filantropia e o espírito humanitário - puderam prever em regras ou categorizar em conjuntos fechados e homogêneos de diferenças, o seu efetivo uso, os ditos constitutivos do biopoder, sofrem a força da contradição, pois, ao mesmo tempo em que produzem as normalizações e incitam à ação medida e avaliada previamente pelos saberes, produzem também acontecimentos não planejados nem previstos pelos conhecimentos difundidos. Assim é que, ao lado das práticas que almejam o bem-estar, surgem outras práticas que acabam promovendo, por exemplo, a incidência de outras doenças na situação de uma doença que está sendo combatida, como é o caso das campanhas contra a obesidade, as quais, pela insistência em associar a magreza à saúde, ajudam a produzir a anorexia, a bulimia, etc. É o caso, da mesma forma, do desemprego imposto ao fumante pelo fato de muitas empresas, fábricas e indústrias não mais aceitarem fumantes em seus quadros 
de trabalhadores. O fechamento de estabelecimentos que não obedecem à lei do silêncio, a qual visa à garantia do sossego das pessoas, mas determina a exclusão, pela perda do trabalho, de vários tipos de profissionais. Outras práticas vão sendo criadas por aqueles que, de alguma forma, resistem às estratégias do biopoder. $\mathrm{Na}$ atualidade, pode-se assistir a certas mudanças nos hábitos dos brasileiros, como reunir amigos e beber em casa para escapar da lei seca, o que significa o fechamento de bares e restaurantes; ou fumar nas calçadas dos bares sob sereno, chuva, o que também pode provocar doenças, criando um novo lugar de encontro de pessoas para uma conversa; e ainda explorar os idosos, os quais, depois que alcançaram a "melhor idade", são convocados a consumir várias espécies de produtos para serem felizes e eternos.

Os enunciados que constroemo biopoder acabam efetuando alguns "tiros que saem pela culatra", provocando a intransigência de alguns em relação a outros, a discriminação daqueles que não se encaixam nas normas do corpo magro, sadio, bonito, feliz. Prova disso é o grande aumento do estado de depressão numa época em que se encontram em todos os lugares as fórmulas para ser feliz. Como afirma Foucault (2004), a felicidade não é mais somente um simples efeito, a felicidade dos indivíduos é uma necessidade para a sobrevivência e o desenvolvimento do Estado. [...] A felicidade dos homens se torna um elemento do poderio do Estado.

Nessa expectativa constante de felicidade, as pessoas clamam por mais regras, mais proibições, vigilância e punição. Cobram segurança e policiamento, exigem câmeras de vigilância, trocando a privacidade pela aparente segurança e aceitando o risco de essa tecnologia ser usada para fins que podem virar-se contra as mesmas pessoas que a pedem. 
O exercício do biopoder é tão eficiente que se torna quase impossível pensar numa forma de resistência que de fato possa funcionar. Foucault fala do cuidado de si, de uma ética da bela existência; mas difundir uma ética de reflexão num mundo em que a moral comanda até mesmo as decisões políticas de saúde, ou em que a lei é a medida do que pode ser feito, não importando outras consequências, torna-se uma utopia diante das comprovações verificáveis da ciência e acatadas pela Justiça. Foucault propõe uma reflexão em torno da morte e da vida nas relações de poder. Se o biopoder é exercido tomando a vida como estratégia, a resistência só poderia ocorrer com a perda do medo da morte - medo que leva uma parte da população a desejar exterminar a outra parcela desta mesma população, como forma de garantir a própria sobrevivência, longevidade e - quem sabe - a possibilidade de se tornar eterna.

\section{Referências}

DUARTE, A. Biopolítica e resistência: o legado de Michel Foucault. In: RAGO, M.; VEIGA-NETO, A. Figuras de Foucault. Belo Horizonte: autêntica, 2008.

FOUCAULT, M. Vigiar e punir: nascimento da prisão. Petrópolis: Vozes, 1987. A arqueologia do saber. Rio de Janeiro: Forense Universitária, 1995a. . A arqueologia do saber. Rio de Janeiro: Forense Universitária,1995. - A verdade e as formas jurídicas. Rio de Janeiro: Nau Ed., 1996. . Em defesa da sociedade. São Paulo: Martins Fontes, 1999. 
. Sobre as maneiras de escrever a história. In: MOTTA, M. B. da (org.) Foucault: arqueologia das ciências e história dos sistemas de pensamento. Ditos e Escritos II. Rio de Janeiro: Forense Universitária, 2000.

. História da sexualidade I: a vontade de saber. Rio de Janeiro: Graal, 2001.

- A governamentalidade. In: MOTTA, M. B. da (org.) Foucault:

estratégia, poder-saber. Ditos e Escritos IV. Rio de Janeiro: Forense

Universitária, 2003.

. Microfísica do poder. Rio de Janeiro: Graal, 2003.

. A tecnologia política dos indivíduos. In: MOTTA, M. B. da (org.)

Foncault: Ética, sexualidade, política. Ditos e Escritos V. Rio de Janeiro: Forense Universitária, 2004.

GADET, F.; PÊCHEUX, M. A língua inatingível. Campinas-SP: Pontes, 2004.

HARDT, M.; NEGRI, A. Império. Rio de Janeiro: Record, 2004.

PELBART, P. P. Vida capital: ensaios de biopolitica. São Paulo: Iluminuras, 2003.

PORTOCARRERO, V. os limites da vida: da biopolítica aos cuidados de si. In: ALBUQUERQUE JÚNIOR, D. M.; VEIGA-NETO, A.; SOUZA FILHO, A.; Cartografias de Foucault. Belo Horizonte: Autêntica, 2008.

RABINOW, P.; DREYFUS, H. Michel Foucault: uma trajetória filosófica - para além do estruturalismo e da hermenêutica. Rio de Janeiro: Forense Universitária, 1995. 



\section{O CORPO TATUADO:}

A IMAGEM DE UMA IDENTIDADE EM 3D

Roselene de Fátima Coito ${ }^{8}$

Partindo da reflexão sobre o que é a história e a quem servem os intelectuais em determinados momentos e/ou lugares, podemos tomar o conceito de identidade como uma construção discursiva flutuante, se tomarmos a história enquanto ciência. Esta, ao fazer recortes, silencia identidades na constituição discursiva, as quais podem estar ou não na 'ordem do discurso vigente'. Em outros termos, o discurso científico é aquele que faz recortes dos objetos dos quais se ocupa, que faz escolhas teóricas, exclui e cria estratégias para se instituir como a prática discursiva da verdade, ocultando, assim, a interpelação do discurso do sujeito enunciador pela ideologia, a qual cria efeitos de evidência para que o discurso se naturalize.

De acordo com Michel Pêcheux (1996, p. 143), o sujeito enunciador é interpelado pela ideologia "nas condições ideológicas de reprodução/transformação das relações de produção". O fato de o sujeito ser interpelado pela ideologia convoca-nos a pensar que o seu dizer, seja na história seja em outra prática discursiva qualquer, é uma prática que faz recortes para atender ao discurso científico autorizado em dada época e

8 Professora do Departamento de Letras e do Programa de Pós-Graduação em Letras da Universidade Estadual de Maringá. 
em dado lugar por determinada formação discursiva, o que faz com que o mecanismo linguístico de objetivação da ciência não seja suficiente para garantir sua neutralidade ideológica, pois “os sujeitos são apanhados nas relações de produção, nas relações de sentido e, com grande complexidade, nas relações de poder", conforme Foucault (1986, p. 298).

Gilles Deleuze, interlocutor de Michel Foucault, ao discutir empirismo e subjetividade a partir das reflexões de Hume, assevera que "a história tem por objeto a organização política e a instituição" e que "ela [a história] manifesta a uniformidade das paixões do homem” (1953, s/d).

Deleuze parte destas premissas ao questionar o problema do conhecimento e o problema moral e não desvincula a questão científica da questão moral, tanto que, nesta reflexão sobre o empirismo e a subjetividade, ele elenca três princípios que afetam o sujeito: a contiguidade, a semelhança e a casualidade. Diz Deleuze sobre isso, partindo de Hume:

[... Hume insiste no paradoxo de sua tese. Quando Hume fala em ato de espírito, de uma tendência, ele não quer dizer que o espírito seja ativo, mas que ele é ativado, tornado sujeito. O paradoxo coerente da filosofia de Hume é de aparentar uma subjetividade que se ultrapassa e não o é menos passiva. A subjetividade é determinada como um efeito, é uma impressão de reflexão. O espírito se torna sujeito, estando afetado pelos princípios (contiguidade, semelhança e casualidade). (DELEUZE, 1953, s/d).

Ao instituir a história como algo que manifesta a uniformização das paixões humanas e como a ciência que tem por objetos a organização política e a instituição social, e cujo espírito não é ativo, mas tornado sujeito, Foucault complementa e/ou corrobora Hume quando alia a questão do poder à do saber. Dito de outra forma, Foucault expande esta reflexão para 
a instância de uma subjetividade "criada" a partir de uma ciência que não se organiza e se institui só para criar identidades a partir de efeitos de subjetividade, mas que também exclui, recorta e silencia identidades pela forma de elaborar efeitos de sentido de subjetividade, como veremos na retomada desta reflexão mais adiante e nas análises dos corpora escolhidos para esta reflexão.

Como poder e saber se implicam mutuamente, pelo fato de estabelecerem entre si novas relações, o poder no e do discurso científico pode gerar efeitos de poder entre e nos enunciados os quais se sobreporão aos sujeitos enunciadores que, na ilusão do dizer, pensam que dizem, ao organizarem seus discursos, mas, estrategicamente, silenciam ou, pelo menos, criam efeitos de silenciamento.

Michel Foucault, em seu livro Em defesa da Sociedade (2002), ao discutir a história antes e depois do Estado moderno, assevera:

A história não é simplesmente um analisador ou um decifrador das forças, é um modificador. Em consequência, o controle, o fato de ter razão na ordem do saber histórico, em resumo, dizer a verdade da histórica, é por isso mesmo ocupar uma posição estratégica decisiva. (FOUCAULT, 2002, p. 204).

Sendo a história um modificador, os discursos da história podem ocupar uma função parodística da realidade, ou seja, pode-se pensar no discurso histórico como um discurso que faz das interpretações dos fatos uma inversão da "realidade" para atender a uma formação discursiva predominante em um determinado lugar, pois a ciência acaba por constituir-se como o discurso da ação. Sendo a ciência o discurso da ação, ela é usada para dissociar identidades a partir do momento em que a análise histórica elimina a noção de guerra pelo princípio da 
universalidade nacional, para instituir um discurso no qual se configura como sacrifício da verdade. Todos esses usos da história revelam que há jogos de relações de forças, há redes de saberes e há um discurso científico que têm sua voz autorizada, porque evidencia uma pretensa verdade.

Seria a ciência (no nosso caso, a história) a portadora da verdade? Que verdade é essa ou, ainda, o que é a ciência?

Em seu texto Arqueologia do Saber Michel Foucault procura descrever a constituição das ciências humanas a partir da interrelação dos saberes, os quais se inter-relacionam discursivamente ao mesmo tempo em que se articulam com as instituições. Diante disso, o filósofo francês questiona como os saberes aparecem e se transformam.

Partindo do pressuposto de que a ciência, seja ela qual for, é um campo do saber, e de que nela estão presentes a ideologia ou ideologias, explícitas ou não no discurso no qual é veiculada, discutiremos, neste primeiro momento, o que Foucault toma como saber e ciência.

De acordo com o filósofo (1986) quando discute a relação entre ciência e positividade, não há pseudociência, mas a não ciência, ou seja, a ciência que não tem o rigor e não atende aos critérios formais que legitimam um saber como ciência. Afirma ainda Foucault que a não ciência estabelece relações com a ciência, pois se preocupa com os objetos dos quais se ocupa, com os tipos de enunciação que põe em jogo, com os conceitos que manipula e com as estratégias que utiliza.

Já com relação ao saber, Foucault (1986, p. 209) assevera que "há saberes que são independentes das ciências, mas não há saber sem uma prática discursiva definida, e toda prática discursiva pode definir-se pelo saber que ela forma". Neste 
sentido, o saber também pode ser uma não ciência, pois serve de "pano de fundo" da ciência e/ou de uma prática que estabelece relações com a ciência. Por outro lado, para se constituir enquanto tal na ciência, o sujeito precisa estar no verdadeiro da época e ter sua voz autorizada, ao passo que no saber ele pode tomar posições para falar dos objetos de que se ocupa em seu discurso e estas posições são possibilidades de utilização e de apropriação oferecidas pelo próprio discurso.

Pelo fato de o sujeito estar no verdadeiro da época e ter sua voz autorizada, o discurso científico é tido pela 'sociedade discursiva' como o discurso da verdade, o discurso que ocupa o espaço da ação. Dito de outro modo, o discurso científico é aquele que faz recortes dos objetos dos quais se ocupa, faz escolhas teóricas, exclui e cria estratégias. Por isso o discurso científico se apresenta como um discurso sobreposto ao discurso do saber, o qual, como prática discursiva, repousa no dizer científico apagando-se, e neste apagar-se oculta a(s) ideologia(s) do/no discurso científico, o qual se institui como a única prática discursiva possível: a prática discursiva da verdade.

Se o discurso científico sobrepõe-se ao discurso do saber por ocupar o espaço da ação, é neste espaço da ação que o funcionamento ideológico de uma ciência deve ser estudado; ou seja, quando o analista do discurso pretende verificar o mecanismo ideológico de determinados saberes que se instituíram como ciência, ele não deverá estudar as contradições formais das proposições científicas, mas sim, o sistema de formação de seus objetos, os tipos de enunciação e as escolhas teóricas. Este sistema de formação dos objetos, os tipos de enunciação e as escolhas, são um mecanismo 
estrategicamente construído na e pela prática discursiva que Foucault toma por ideologia.

Levando em consideração que tanto o discurso da história quanto o da cultura se utilizam de um mecanismo estrategicamente construído na prática discursiva enquanto saber e pela prática discursiva enquanto ciência, podemos dizer que tanto uma quanto a outra instituem-se como verdades, e por meio de estratégias discursivas ocultam a(s) ideologia(s).

Conforme Paul Henry, a partir da reflexão sobre o que é a história e a quem servem os intelectuais (não só os da história) em determinados momentos e lugares, quando ela se utiliza de um sistema - seja na formação dos objetos, seja nos tipos de enunciação, seja ainda nos conceitos de como se dá seu estudo, linear e evolutivamente, e de como o Estado moderno a vê enquanto reforço do discurso da ordem e da paz -, é possível pensar que a "história não existe". Grosso modo, pode-se dizer, com base na reflexão de Henry, que a história é interpretação dos fatos. Não obstante, é preciso questionar se estas interpretações acontecem em redes do saber e como são estrategicamente construídas, ou seja, se elas não estão apenas a serviço da 'ordem do discurso vigente'. O mesmo se pode pensar do discurso da cultura, o qual, mesmo pretendendo unir acontecimentos múltiplos em um único discurso de uma mentalidade de cultura, guarda silêncio ao se instituir como discurso da suposta construção discursiva da objetividade, pois, mesmo com o efeito do afastamento e da imparcialidade, o sujeito enunciador é interpelado pela ideologia, como vimos acima na citação de Pêcheux. Por isso discutiremos, como reflexão inicial, a construção da identidade na história e, posteriormente, na cultura. 
Nos estudos atuais sobre identidade, muitas vertentes teóricas se posicionam, ora se completando ora se opondo.

De acordo com Foucault, em diálogo com Gilles Deleuze em Microfísica do Poder, "[...] a teoria não expressará, não traduzirá, não aplicará uma prática; ela é uma prática” (2003, p. 71). Os filósofos, quando abordam a questão da teoria, estão refletindo sobre o atual papel do intelectual e do poder, pois nem o campo teórico nem o intelectual se desvinculam de uma função-poder na sociedade discursiva. Em outras palavras, a teoria é um caminho para se refletir sobre a construção dos saberes e a constituição da ciência e da cultura, e essa reflexão se dá pela via intelectual. Para Gilles Deleuze e para Foucault, o intelectual deixou de ser uma vOz que representa as massas, pois "as relações teoria-prática são muito mais parciais e fragmentárias...” (2003, p. 69), e isso faz com que não exista mais representação, apenas ação. Isto significa que

o papel do intelectual não é mais o de se colocar 'um pouco na frente ou um pouco de lado' para dizer a muda verdade de todos; é antes o de lutar contra as formas de poder exatamente onde ele é, ao mesmo tempo, o objeto e o instrumento: na ordem do saber, da "verdade", da 'consciência', do discurso (FOUCAULT, 2003, p. 71).

A reflexão destes filósofos nos leva a concordar que não há teoria totalizante ou totalizadora, pois toda e qualquer abordagem teórica é ideológica, no sentido de ser uma luta travada entre poderes e saberes, uma luta "localizada" que continuamente se multiplica.

Quando se pensa nessa localização teórica multiplicadora - seja de si mesma ou não - o conceito de identidade se revela 
como um aporte teórico que em sua prática discursiva também silencia grupos e/ou individualidades não presentes na formação discursiva de determinado lugare/ou de determinada época. Há nele formações ideológicas que fazem parte de uma formação discursiva - seja por parte da intelectualidade seja das massas - que, pelo poder que exercem, contribuem para a ordem do discurso vigente, o qual, via de regra, é a do discurso autorizado, como podemos ver nos trechos abaixo, transcritos de um livro de História do Brasil de José M Catharino e de um livro do jornalista Tony Marques, publicados no Brasil, respectivamente, em 1995 e 1997, os quais destacam a imagem dos corpos.

O texto de José Martins Catharino intitulado Trabalho Indio em Terras de Vera Cruz ou Santa Cruz e do Brasil - tentativa e resgate ergonlógico, é um texto histórico que descreve a vida dos índios e seus costumes por meio de relatos dos brancos europeus que aqui vieram por ocasião do "descobrimento" do Brasil. É composto por fragmentos dos descobridores e por um dicionário que define etimologicamente termos como trabalho, trabalho índio, índio, propriedade, liberdade, entre outros. Aqui nos pautaremos em apenas alguns relatos e fragmentos a respeito do trabalho feito sobre e com o corpo: as ornamentações corporais e a dança.

Antes de entrarmos nos fragmentos e relatos, faz-se necessário analisar como Catharino (1995, p. 583) classifica a dança. Segundo o autor, a dança era um

trabalho gratificante por si mesmo, por puro deleite, em muitas ocasiões e com várias conotações: ligados à guerra, durante sua preparação e após vitória; para receber visitantes e para visitar; religiosa; durante a cerimônia de perfuração do beiço de meninos; antes e depois da caça e da pesca; antes e durante festim com carne do inimigo etc. [...]. 
Como vimos, a dança era vista como um trabalho. O trabalho de "puro deleite". Esta descrição "puro deleite", para o branco europeu ou para nós os civilizados, parece barbárie. Corrobora essa afirmativa o trecho seguinte, no qual Catharino, citando Staden, relata: "Partido [...] o padecente em quartos, [...], e assados estes ou cozidos, os vão comendo em seus banquetes, com grandes bailes e bebidas de vinho [...]". (CATHARINO, 1995, p. 584).

Nesta citação não há um comentário sequer sobre as características próprias da cultura indígena de determinados grupos étnicos, ou, em outros termos, não há uma explicação do motivo da antropofagia. Este fato alimenta o senso comum de que todas as etnias indígenas são e/ou foram antropofágicas e de que exerciam essa prática por puro deleite aliado ao trabalho da dança.

No texto de Catharino há também referências a um relato de Anchieta sobre os índios e os franceses que aqui se encontravam, no qual o jesuíta dizia, em tom crítico, na carta de S. Vicente, que os franceses que estavam no Rio de Janeiro já tinham se separado da Igreja Católica e se misturado aos selvagens, e até pintavam-se "com suas tintas pretas e vermelhas (de jenipapo e urucum), adornavam-se com penas, e, às vezes, andavam nus só com uns calções" (CATHARINO, 1995, p.584).

Neste livro, direcionado ao terceiro grau, confirmase o tempo todo, nos relatos de vários autores transcritos por Catharino, a imagem do índio como selvagem e de seus hábitos e costumes como não civilizados, e não como diferentes dos do branco europeu. 
Catharino relata enunciados sobre o trabalho indígena de que este trabalho não era feito sobre o corpo só por ocasião da dança, mas que era um costume indígena:

Embora usuais as deformações causadas por peças introduzidas em partes do corpo - do que trataremos adiante, a por esmagamento só encontramos na obra de Lèry, produzindo achatamento do nariz, oposto da dilatação, do beiço (CATHARINO, 1995,s/d).

Quanto ao nariz procedem ao contrário da nossas parteiras, que os apertam ao nascer as creanças para que os tenham afilados: entre os índios o bonito é tê-los chatos, e para isso os esmagam nos recém-nascidos, como se faz em França com certas raças de cães. (CATHARINO, 1995, s/d).

O que podemos notar nestes dois enunciados - relato e fragmento - é a reprodução dos conceitos do branco europeu sobre o índio brasileiro, pois nesse livro, publicado em 1995, ainda predomina a visão do índio como animal, ou como uma "raça" inferior, já que o autor não coloca uma reflexão a respeito das diferenças étnicas e culturais, reforçando essa imagem "esteticamente feia", por se diferenciar do branco europeu, na utilização da reprodução do discurso de Lèry sobre deformações, beiço, nariz chato como certas raças de cão.

A estratégia de construção destes enunciados e dos demais deste livro, numa pretensa isenção subjetiva, é a comparação, e nesta, a reafirmação da concepção do branco europeu sobre o índio brasileiro, que não aparece como uma etnia com singularidades que devam ser respeitadas enquanto tais, mas como uma raça parecida com a dos animais. É um discurso histórico da ordem e da paz, e não das lutas travadas entre os europeus invasores e os índios que aqui viviam. 
Outro enunciado que revela o caráter comparativo entre as etnias e reafirma a supremacia do branco europeu diz respeito aos ornamentos para as festividades e à dança:

Anos mais tarde, Lèry, falando de vários enfeites, mencionaria
carapuças e "outros ornatos de pennas verdes, encarnados, azues e de
outras cores naturaes de incomparável belleza". E, o que mais pertine,
descreveu a técnica de confecção: "Taes pennas são tão bem mescladas,
combinadas e ligadas umas às outras sobre talisca de madeira com fios
de algodão, que nenhum plumaceiro de Paris o faria melhor. Assim
vestidos, dir-se-iam em trajes de pellucia”. (CATHARINO 1995,
s/d). [...] e, enfileirando-se com grous, não cessam de dançar, de entrar e sahir das casas até que a festa se conclua pello esgotamento da bebida. (CATHARINO 1995,s/d.).

No primeiro enunciado, apesar do elogio, a comparação dos trajes caracteriza o índio também como um animal, um animal de pelúcia, confirmando o caráter animalesco desta etnia, enquanto no segundo enunciado temos o índio não como um resgate ergológico, mas sim, como o resgate de uma memória discursiva do dizer sobre o índio enquanto alguém que se embriaga até o amanhecer, singularizando-o como um ser festeiro e preocupado em se divertir e não em trabalhar, além da imagem de alcoólatra a ele atribuída pela mentalidade social vigente. Nos dizeres de Catharino, mesmo quando transcreve os dizeres de Lèry, há uma confirmação, por meio da estratégia comparativa e das palavras utilizadas, da superioridade do branco europeu sobre o índio, demonstrando, assim, um mecanismo ideológico na estratégia discursiva utilizada pelo autor, como podemos ver nos seguintes enunciados:

Além da identificação do índio como tipo humano, pela via comunicante do trabalho, sua caracterização, coletivamente 
considerada, não prescinde das ciências sociais [...] (CATHARINO, 1995, p.14- grifos nossos).

No enunciado destacado se percebe que só o trabalho torna o índio diferente do animal e o faz humano. $\mathrm{O}$ enunciado começa com um conector que cria o efeito de sentido de continuidade, traz na memória discursiva a incivilidade indígena e sua quase animalidade diante dos olhos do branco europeu. Nos enunciados a seguir, o índio aparece marcado o tempo todo como um "objeto" exótico: "O grau de interação social entre os índios e a tribo era elevado, até comunitário”. (CATHARINO,1995, p.14-grifos nossos).

Nas páginas iniciais desse livro há também uma espécie de glossário com as palavras utilizadas pelos estudiosos da etnia indígena para a ela referir-se. Deste pequeno apanhado de designações selecionaremos aquelas que Catahrino diz serem derivadas de Brasil (da página 17 à 21), como brasileiro, brasiliano, brasílico, brasilíndico, além de outras, como bugre (desconfiado, rude, inculto, grosseiro), canibal, gentio (idólatra), negro, negro gentio, negro/índio (nos documentos jesuíticos), selvagem (Couto de Magalhães), silvícola (Euclides da Cunha) entre outros.

Como se observa, muitos intelectuais brasileiros, além dos jesuítas, fomentam em sua designação da etnia indígena a discriminação e o preconceito. O próprio Catharino revela, em um comentário sobre o glossário designativo que elenca, seu posicionamento ideológico com relação a esta etnia, defendendo os colonizadores que aqui aportaram. Diz ele: 
aliás, algo injusto em relação a Colombo (houve quem sugerisse Colômbia). (CATHARINO,1995, p.18).

Diante dos fragmentos e relatos expostos e analisados até aqui, cremos ser possível dizer que as estratégias discursivas, os tipos de enunciados, os objetos tratados e a sistematização do dizer científico dos autores tratados até este momento confirmam que a ciência se institui como um campo do saber que recorta, exclui e silencia outros dizeres ao fazer uma leitura com pretensão de singularização e objetivação que oculta a(s) ideologia(s) que veicula (m) e opacifica (m) identidades que acabam por permanecer na marginalização e descriminação étnica. Diante disto nos perguntamos: qual dispositivo de análise e qual objeto de estudos nos permitiriam traçar um perfil da construção identitária de coletividades e de individualidades, desvelando a história como superfície de opressão, como singularidade de identidades e como biopoder?

Para tentarmos responder a esta questão, passamos a refletir sobre a tatuagem em sua manifestação histórica e na historicidade do dizer inscrito nos corpos.

\section{Identidade como resposta genealógica: o lugar de inscrição dos acontecimentos}

Analisando-se a história sob a ótica genealógica, a qual, segundo Foucault, discute o porquê dos saberes e explica sua existência e transformação situando-os como peça de relações de poder ou incluindo-os em um dispositivo político, procurase, nesta voz autorizada e na não autorizada - isto é, no que foi 
se instituindo como ciência e cultura e no que não o foi -, o lugar de inscrição dos acontecimentos que, de acordo com o filósofo francês, pode revelar-se nos corpos. Por isso traçaremos um breve perfil da história inscrita no corpo tatuado a partir de três dimensões desse corpo, a saber: 'opressão', tida como marca de indivíduos subjetivados pela sociedade como marginais; 'liberdade' enquanto ato de pertença a uma coletividade, e o biopoder, quando a ciência tecnológica, a qual envolve também a questão da saúde pública, permite aos indivíduos se subjetivarem na sociedade. Antes de passarmos a este breve perfil, colocaremos algumas reflexões sobre identidade.

Boaventura de Sousa Santos, na introdução de seu livro intitulado Pela mão de Alice: o social e o político na Pós-Modernidade, reflete sobre a questão da identidade partindo do pressuposto de que mesmo nas identidades mais sólidas há o ocultamento de "negociações de sentido" sendo estas, por isso, identificações em curso. Essas identificações partem de quem pergunta sobre a identidade, e quem pergunta sobre ela parte de referências hegemônicas e, ao mesmo tempo, de alteridade. Por este fato, segundo o autor, é necessário "conhecer quem pergunta pela identidade, em que condições, contra quem, com que propósitos e com que resultados" (SOUSA SANTOS, 2001, p. 135).

Se nos pautarmos nesta reflexão à qual nos convida Boaventura de Sousa Santos, conforme vimos no item anterior, a ciência e a cultura perguntam sobre a identidade em uma posição de alteridade que negocia sentidos para confirmar a 'ordem do discurso' da história, ou seja, para reafirmar a supremacia do branco europeu sobre as demais etnias, colocando a etnia negra e a indígena no patamar da animalidade - entendida como oposição de civilidade -, seja do relato e fragmentos descritivos do trabalho de ornamentação do índio brasileiro quando da chegada do 
branco europeu ao Brasil, seja na descrição dos seus costumes e tradições culturais. Trava-se, assim, nos discursos científico e cultural, uma ou mais lutas para se discutir "quem somos nós", sendo que na Modernidade, de acordo com o teórico português, há uma descontextualização do termo pelo fato de se cruzarem tensionalmente os termos subjetividade individual e subjetividade coletiva; portanto, conforme Boaventura, "O primeiro nome moderno da identidade é a subjetividade". (SOUSA SANTOS, 2001, p. 136).

Da subjetividade também trata Michel Foucault. Em seu ensaio Deux essais sur le sujet et le pouvoir (1984), para se defender de teóricos que diziam que sua teoria anulara o sujeito e falara apenas do poder, diz que tentou produzir uma história dos diferentes modos de subjetivação do sujeito na nossa cultura estudando a maneira como o ser humano se transforma em sujeito, o que, segundo ele, passa por três níveis de objetivação - a investigação científica, a objetivação do sujeito produtivo e a objetivação do sujeito nas práticas divergentes -, pois, para esse filósofo, o sujeito é apanhado nas relações de produção, nas de sentido e, com grande complexidade, nas de poder. Sendo o poder algo que se exerce, não se exerce sem lutas, e estas são "recusas de abstrações [como 'quem somos nós?'], uma recusa da violência do Estado econômico e ideológico que ignora que somos indivíduos, e uma recusa da inquisição científica e administrativa que determina nossa individualidade". (FOUCAULT, 1984, p. 299).

Essas lutas dão-se de três formas: como oposição às formas de dominação, como denúncia de exploração e como algo que combate tudo o que liga o indivíduo a ele mesmo. As lutas se dão em forma de estratégias, discursivas ou não, que "sonham em transformar-se em relação de poder", até mesmo do poder, talvez ilusório, do domínio sobre o próprio corpo, 
o qual estamos pensando como um lugar de inscrição dos acontecimentos e da língua e da linguagem como instrumentos do discurso que materializam a história, inclusive a genealógica, pois

É a partir da linguagem e de sua manifestação nos diálogos do cotidiano, nos textos e nas imagens que construímos as referências que viabilizam a existência da memória e que permitem que nos identifiquemos como membros deste ou daquele grupo social (FERREIRA; ORRICO, 2002, p. 8).

Destarte, se em uma rede complexa de discursos há uma memória que viabiliza ao sujeito identificar-se enquanto grupo e/ ou enquanto indivíduo, que é o dilema da subjetivação do sujeito da e na Modernidade, conforme Boaventura, não podemos descartar o fato de que a identidade é algo construído histórica, cultural, sociológica e conceitualmente, e como tal, possui um caráter flutuante de definição. Por isso refletiremos sobre a identidade (que não vem desacompanhada da questão do poder político, ideológico, econômico e biopolítico) de grupos e/ou indivíduos a partir da tatuagem inscrita nos corpos.

Antes de buscarmos uma reflexão sobre a identidade pela tatuagem, vamos tratar sucintamente dela, a tatuagem, nos processos históricos, arqueológicos e religiosos com respaldo no estudo feito pelo jornalista Tony Marques sobre a tatuagem em seu livro O Brasil tatuado e outros mundos.

De acordo com o jornalista, a tatuagem já aparecia em cavernas da Pré-História, as quais escondiam corantes, furadores e cálices contendo pirita de ferro, própria para a tatuagem. A tatuagem, também tomada como marca, como sinal, revela hábitos e costumes que constroem o saber do homem sobre si mesmo e sobre o outro, pois pelos relatos sobre a tatuagem 
temos que esta produz sentidos de identificação que marcam os efeitos de sentido de opressão, de pertença - individual e/ou coletiva - e de liberdade.

Arqueologicamente, as marcas no corpo poderiam significar as cicatrizes da supremacia de um povo sobre outro, dos rituais dos fatos da vida biológica (nascimento, puberdade, casamento), de pertença a determinados grupos, de efeitos religiosos e de poder sobre o próprio corpo aliado ao biopoder que envolve uma política de vigilância sanitária - no caso do corpo tatuado que necessita, nos tempos atuais, de agulhas esterilizadas para marcar seus corpos. Assim, as marcas do corpo não identificam apenas individualidades, mas todo o processo histórico que constrói essas identidades, como se deu, por exemplo, com os citas, os tebanos e os trácios, os quais tinham por hábito marcar o corpo do inimigo com uma cicatriz, a qual revelava a supremacia deles sobre seus inimigos. Em muitas passagens bíblicas também as marcas cicatrizes, sinais e até mesmo tatuagens - denotam a separação entre pecadores e tementes a Deus; e, também, há tatuagens em grupos que se identificam por marcas semelhantes.

Os corpos tatuados de tribos aborígines de várias etnias (Ilhas Marquesas, Tailândia, Samoa, Havaí, Nova Zelândia e Bornéu) demonstram que a identidade se dava de forma coletiva. Neste caso, a identidade é um fator de pertença não individual, mas coletiva. Os aborígines constituíam um só corpo, identificado pelo agrupamento para se autoprotegerem e para travarem embates, que poderiam ser harmoniosos, no caso de alianças entre tribos, ou conflituosos, nos casos de guerra.

O mesmo ocorria com as tribos indígenas e negras, as quais se utilizavam da tatuagem como meio de identidade em rituais tanto religiosos como bélicos. 
Os nativos das tribos munducurus traziam corpos pintados como sinal de pertença a um grupo específico. De acordo com Marques, as pinturas eram feitas com urucum e jenipapo, matérias-primas que forneciam tintura para ornamentar a pele das nações indígenas nos rituais de nascimento, puberdade e outros; ou seja, os rituais eram a identidade marcada nos corpos. Essas marcas foram extintas por micróbios - quando feitas como escarificações - e pelos novos senhores da terra, que proibiam rituais de tradição não europeia.

Os escravos moçambicanos, quando eram trazidos ao Brasil, vinham com a pele marcada por escarificações que os identificavam como pertencentes a um determinado grupo. De acordo com Marques (1997, p, 134), "aqui não vingou, a não ser como forma de identificação da criança ou como resistência cultural". Este sinal de pertença a uma etnia não vingou porque os escravos negros não tinham por que riscar a pele longe de sua gente e de sua cultura, e também porque seus senhores não permitiam que seus investimentos se "deformassem". A escarificação era uma tatuagem "feita com espinho introduzido sob a pele, ao longo de traços previamente desenhados" depois "a pele [era] levantada, para em seguida ser cortada por lâmina de pedra ou de metal" (MARQUES, 1997, p. 132). A única marca que os senhores dos escravos permitiam eram as marcas que eles faziam com ferro quente como sinal de posse e de punição, isso mostra e, ao mesmo tempo, oculta a História oficial dos negros no Brasil.

O que se vê pelas marcas dos corpos indígenas e negros é que quem, no processo histórico de dominação, determinou as identidades indígena e negra no Brasil foi o branco europeu, que apagou a identidade de pertença para instituir a identidade da posse. Mesmo assim, como mostra o relato de Marques, houve resistência. 
Voltemos agora à questão da identidade: como determinar de onde viemos se na Pré-História os corpos eram tatuados e se os aborígines traziam marcas tribais diferentes e coletivas? E se pensarmos também no índio brasileiro e no negro que para cá foi trazido, como dar a certidão de origem sem a documentação que a comprove e sem testemunhos, por terem sido apagados pela história oficial por discursos e pela ausência de imagens? E como conceituar a identidade inscrita no corpo na Modernidade ou na Pós-Modernidade?

Nos anos de 1960 e 1970 as tatuagens eram feitas com temas da contraculutra e da indústria $p \circ p$, de acordo com Marques. Ganhou força com o movimento hippie nos Estados Unidos e a indústria internacional movimentou milhões de dólares com máquinas de tatuar, e, ao mesmo tempo em que a tatuagem marcava a diferença, um efeito de subjetividade individual, marcava também um grupo como escravo da originalidade, uma subjetividade coletiva. Além de ser marca de subjetividade, de ser uma marca política de contracultura e de poder econômico, a tatuagem passa a ser também uma identidade que envolve a saúde pública ou a biopolítica, pois "a tatuagem atual [na Rússia] recém-libertada, é feita da pior maneira possível: como agulhas, usam-se pontas de fios e cabos elétricos; como tinta, uma mistura de urina e fuligem; assepsia zero”. (MARQUES, 1997, p. 77).

Ao mesmo tempo em que envolve também, em tempos de HIV, a saúde pública como biopolítica, a tatuagem reflete o poder sobre o próprio corpo, o qual, sacrificado por vontade própria ou por indução de uma ideologia, revela o biopoder que o indivíduo instaura sobre si mesmo, em um tempo e um espaço que identifica sujeitos e narra história(s). 
De acordo com Marques, (1997, p. 80),

os velhos meios de adquirir identidade - o trabalho, os sentimentos, o bem público - perderam o sentido. O sujeito adquire identidade se tatuando ou se tribalizando de qualquer forma, em ato ou pensamento. E a certeza mágica da identidade: tatuei-me; agora eu sou.

Pensando nesta assertiva de Marques, podemos dizer que o sujeito moderno constitui sua identidade ao se marcar como singular por um símbolo pretensamente único de seu corpo. É o biopoder - o poder sobre si e sobre o próprio corpo - que permite na modernidade, esta tribal e individual ao mesmo tempo, o sujeito construir sua identidade coletiva e singular.

Para finalizar, podemos dizer que os gêneros não oficiais que relatam a história e a identidade, como é o caso deste texto feito por um jornalista, são gêneros que abordam os saberes sobre a própria história e a identidade mais proficuamente do que os discurso da cultura e da história instituída como ciência, os quais parodiam a realidade, dissociam a identidade e sacrificam a verdade por meio de estratégias que, no modo de organização dos discursos, omitem as lutas e a subjetivação dos sujeitos enquanto indivíduos, fragmentando imagens de sujeitos anulados em sua dignidade também pelo olhar da cultura, ao produzirem como verdade um dizer pretensamente objetivo e neutro.

\section{Referências}

BAKHTIN, M. M. Marxismo e filosofia da linguagem: problemas fundamentais do método sociológico na ciência da linguagem. São Paulo: Hucitec, 1999. 
CATHARINO, J. M. Trabalho indio em Terras da Vera Cruz ou Santa Cruz e do Brasil - tentativa de um resgate ergonlógico. Rio de Janeiro: Salamandra, 1995.

DELEUZE, G. Empirisme et Subjectivité. Essais sur la Nature Humanine selon Hume. Épimethée. Essais Philosophiques- Collection dirigée par Jean Hyppolite.Presses Universitaires de France - Paris, 1953.

FERREIRA, L. M. A; ORRICO, E. G.D. (orgs) Linguagem, identidade e memória social - novas fronteiras, novas articulações.Rio de Janeiro: DP\&A, 2002.

FOUCAULT, M. Vigiar e punir. Nascimento da prisão. Petrópolis: Vozes, 1977.

- A arqueologia do saber. Rio de Janeiro: Forense Universitária, 1987. Microfísica do poder. 13. ed. Rio de Janeiro: Graal, 1979.

. Deux essais sur le sujet et le pouvoir. In: DREYFUS, H.;RABINOW, P.

Michel Foucault. Un parcours philosophique, Paris, Gallimard, 1984, p. 297321. . A ordem do discurso. São Paulo: Loyola, 1999. . Em defesa da Sociedade - Curso de Collège de France (1975 - 1976) Trad. Maria Ermantina Galvão. São Paulo: Martins Fontes, 2002.

HENRY, P. A história não existe? In: ORLANDI, E. P. Gestos de leitura: da História no Discurso - Homenagem a Denise Maldidier. Trad. Bethania Mariani et al. Campinas, São Paulo: Ed. da Unicamp, 1994. (Coleção Repertórios).

MARQUES, T. O Brasil tatuado e outros mundos. Rio de Janeiro: Rocco, 1997.

PECHEUX, M. O mecanismo do (des)conhecimento ideológico. In: ZIZEK, S. (ORG.) Trad. Vera Ribeiro. "Um mapa da ideologia”. S/d, 1996 - Coleção Contraponto.

SOUSA SANTOS, B. de. Pela mão de Alice: O social e o político na pósmodernidade. 8. ed. São Paulo: Cortez, 2001. 



\section{Segunda parte}

Discurso e normalização dos sujeitos: imagens de exclusão/inclusão 



\section{MÍDIA E ESTRATÉGIAS DE GOVERNAMENTALIDADE DO CORPO DEFICIENTE:}

POLÍTICAS PÚBLICAS AFIRMATIVAS E IDENTIDADE EM TELA Érica Danielle Silva ${ }^{9}$, Ismara Tasso ${ }^{10}$

\section{Considerações iniciais}

Dentre as atuais práticas discursivas midiáticas nacionais, a televisiva tem notável participação no processo de constituição dos sujeitos. De forma específica, no que tange à identidade e à representação visual de sujeitos integrantes de populações minoritárias, as materialidades significantes que versam sobre a inclusão de pessoas com deficiência ganham ênfase e visibilidade. A recorrente exibição de produções sobre o tema justifica-se pela emergência e existência de políticas afirmativas as quais, sob o estrato da ordem da lei e da ordem da historicidade dos sujeitos anormais, podem ser apreendidas especialmente a partir do século $\mathrm{XX}$, momento em que se ampliam os serviços de assistência à pessoa com deficiência. Assim, o que se enuncia e aquilo a que se

9 Doutoranda do Programa de Pós- Graduação em Letras da UEM.

10 Professora do Departamento de Letras e do Programa de Pós-Graduação em Letras da UEM. 
assiste sobre essa temática na televisão consolidam práticas que instituem e promovem políticas de inclusão, cuja emergência tem, fundamentalmente seus princípios relacionados com o progresso da ciência e com sua aplicação em diversos campos, bem como ao engajamento de vários setores da sociedade na luta em prol do bem-estar comum (SILVA, 1987).

No último século, inúmeras contribuições provenientes de debates científicos e sociopolíticos desencadearam mudanças teórico-metodológicas significativas no modo de tratamento e de conceituação da deficiência. Em curto, médio e longo prazos essas alterações proporcionaram a criação de programas e de organizações que ampliaram os benefícios às pessoas deficientes, favorecidos pela noção de normalização para a deficiência.

Diante de tal possibilidade e da singularidade conferida ao regime do olhar a pessoa com deficiência, a identificação, em tela, do que se apresenta como anormal - seja física, mental ou sensorial - configura-se tanto por sua natureza biológica quanto pelas especificidades de outros campos de saber que discursivizam o corpo deficiente. Recorre-se, para tanto, ao emprego de mecanismos e de estratégias que operam discursivamente nas modalidades verbal, visual e sonora. Trata-se, no caso, de dispositivos operacionais da linguagem audiovisual por meio dos quais os sujeitos à margem são espetacularizados na mídia televisiva, de forma agradável aos olhos do sujeito-telespectador. Isso ocorre, em especial, quando apresentados no efetivo desempenho de diferentes atividades de natureza social.

Assim, por considerarmos a mídia televisiva a superfície de inscrição de enunciados que retomam, deslocam e ressignificam sentidos sobre o corpo deficiente, propomo-nos demonstrar como, no exercício da governamentalidade, a identidade do 
sujeito com deficiência é construída a partir de uma organização simbólica que representa as três formas de governo - a de si mesmo, a do Estado e a do Outro. Para isto tomamos como material de análise uma propaganda veiculada na mídia televisiva ${ }^{11}$.

\section{A emergência de políticas inclusivas: um breve percurso}

A partir do século XX, sobretudo depois da Primeira Guerra Mundial (1914-1918), os empreendimentos voltados à assistência às pessoas com deficiência passaram a contemplar a reabilitação desses sujeitos. Silva $(1987,310)$ ressalta que, nesse período, os estudiosos do movimento de reabilitação provocaram "um intercâmbio de informações e de sugestões entre todos os que se interessavam pelo problema, estabelecendo uma espécie de organização internacional de caráter informal". O período do Pós-Guerra, além de causar mudança de sensibilidade diante do corpo monstruoso, estimulou programas de reabilitação, possibilitando serviços gratuitos às pessoas que portavam deficiências devido à atividade militar. A França, por exemplo, garantiu às pessoas 'incapacitadas' fisicamente, a inscrição gratuita em uma escola profissionalizante para que elas pudessem ser recolocadas no mercado de trabalho, além de cuidados médicos, aparelhos ortopédicos e cadeiras de rodas (SILVA, 1987).

11 Este texto parte das discussões desenvolvidas na dissertação de mestrado intitulada "Movimentos identitários e políticas de inclusão na mídia: a (d)eficiência e tela", apresentada ao programa de pós-graduação em Letras da UEM - Universidade Estadual de Maringá- em 2010 e integra as pesquisas do GEDUEM - Grupo de Pesquisa CNPq. 
A conscientização sobre a necessidade de programas mais amplos de incentivo à reabilitação física, que também se estendessem à deficiência mental e às deficiências sensoriais, ganhou força com o fim da Segunda Guerra Mundial (19391945). Sensibilizadas pela causa da deficiência, organizações internacionais comandadas pela Organização das Nações Unidas, entre elas o Fundo de Emergência das Nações Unidas para as Crianças (UNICEF), a Organização Internacional do Trabalho (OIT), a Organização Mundial de Saúde (OMS), a Organização das Nações Unidas para Refugiados e a Organização das Nações Unidas para Educação, Ciência e Cultura (UNESCO), desenvolveram um contínuo e silencioso trabalho a fim de que a reabilitação chegasse à maioria dos países do mundo. No Brasil, em 1956, por iniciativa de Jânio Quadros, então governador do Estado de São Paulo, foi criado na USP o Instituto Nacional de Reabilitação, que se tornou o primeiro centro de reabilitação global do Brasil e modelo para futuros empreendimentos dessa natureza.

Entre as medidas de alcance universal aprovadas pela Assembleia Geral da ONU destacam-se as Declarações dos Direitos das Pessoas com Retardo Mental, em 1971, e a dos Direitos das Pessoas Deficientes ${ }^{12}$, em 1975. Ambas tiveram por finalidade estabelecer formas de conduta para o tratamento equânime da questão com vista a uma assistência à deficiência física que preponderasse sobre as demais. Nos dois documentos o termo "pessoa deficiente" corresponde a "qualquer pessoa incapaz de assegurar por si mesma, total ou parcialmente, as necessidades de uma vida individual ou social normal, em

12 Ambos dão expressão concreta aos princípios contidos na Declaração Universal dos Direitos Humanos, adaptada e promulgada em 1948. Podem ser lidas na íntegra no site http://www. faders.rs.gov.br/portal/index.php?id=legislacao\&cat $=6$ (Acessado em 12/03/2010). 
decorrência de uma deficiência, congênita ou não, em suas capacidades físicas ou mentais". A partir dessa época oficializase o direito ao exercício pleno de cidadania aos sujeitos com deficiência no tocante aos aspectos saúde, educação, moradia e capacitação profissional, condições necessárias para torná-los produtivos e úteis à sociedade (corpos dóceis).

Inúmeras medidas - de iniciativa estatal e de organizações não governamentais - voltadas à conscientização sobre a deficiência foram tomadas por organizações públicas e particulares. Uma dessas medidas foi a promulgação, por parte da ONU, do ano de 1981 como o Ano Internacional da Pessoa Deficiente (Resolução 31/123, de 1976). Tendo como tema "Participação plena e igualdade" e como objetivo "dar condições para a implementação das resoluções anteriores, pela conscientização do mundo todo quanto à problemática das pessoas portadoras de deficiências" (SILVA, 1987, p. 329), o projeto deu visibilidade a extensão do problema instaurado, marcado por milênios de discriminação e de desvalorização do deficiente (SILVA, 1987).

Como ponto culminante desse processo de conscientização, o período de 1983 a 1992 foi declarado a "Década das Pessoas Portadoras de Deficiência". Nesse período foi instituído o Programa de Ação Mundial ${ }^{13}$, com o objetivo de promover medidas para a prevenção das incapacidades e a participação plena das pessoas com deficiência na vida social. Tal documento, de âmbito internacional, detalha o tratamento a ser dado aos sujeitos pertencentes a esse grupo. Aclamava-se, na ocasião, que as pessoas com deficiência deveriam desempenhar suas obrigações como adultos, já que suas atitudes influenciavam na construção de sua imagem na sociedade. Estimulou-se a

13 Disponível em <http://www.cedipod.org.br/w6pam.htm>. (Acessado em 10/08/2009). 
criação de organizações compostas pelas próprias pessoas com deficiência, a fim de que expressassem suas opiniões acerca das prioridades e assim viessem a exercer influência sobre as instâncias governamentais responsáveis pelas decisões, assim como sobre todos os setores da sociedade. Para isso, segundo o programa, fazia-se necessário que todos os meios de informação pública cooperassem, apresentando ao público, essencialmente, a importância da mudança de atitudes, de modo a combater os estereótipos e os preconceitos tradicionais. Como um dos meios de efetivar esta última proposta destaca-se a importância atribuída à representação das pessoas com deficiência veiculada no rádio, no cinema, na fotografia e na imprensa. Segundo o programa, um elemento fundamental nesse processo seria que as próprias pessoas deficientes pudessem apresentar seus problemas e sugerir formas de resolvê-los.

Nota-se, a partir dessa mobilização, que as pessoas com deficiência foram chamadas a cumprir seu direito de participação na sociedade, e ao Estado coube efetivar, por meio de políticas públicas, ações concretas de acessibilidade e de igualdade. Documentos oficiais estimularam o investimento econômico e a sensibilização sobre os direitos adquiridos por esse grupo. Dessa forma, as iniciativas destinadas a proporcionar às pessoas com deficiência o bem-estar e o direito à cidadania, compreendiam, além de eliminação de barreiras arquitetônicas, também as barreiras sociais relacionadas ao preconceito e à discriminação.

Como após o término da Década da Pessoa Deficiente ainda subsistiam problemas dessa natureza, a ONU manifestou o desejo de que as metas do Programa de Ação Mundial se estendessem para além da década estipulada. Propôs-se chegar com êxito, em 2010, a uma sociedade 'para todos', por meio de planos estratégicos de prevenção, reabilitação e equiparação de 
oportunidades. Além disso, destacou-se a preocupação linguística, solicitando-se a revisão de traduções dos termos 'impedimento', 'deficiência' e 'incapacidade'.

Em 1999, em Londres, a Assembleia Governativa da Rehabilitation Internacional aprovou a Carta para o Terceiro Milênio, a qual proclama que os avanços nos ambientes físicos, sociais e culturais desenvolvidos no século XX deverão se estender à maioria da população com deficiência, para tornar possível sua participação comunitária. Determina ainda o documento que os direitos humanos de cada pessoa, em qualquer sociedade, sejam reconhecidos e protegidos, e destaca a necessidade de se criarem políticas que sejam sensíveis à questão e respeitem a dignidade e a diversidade das pessoas. Incentiva, sobretudo, a criação de programas contínuos e de âmbito nacional para reduzir ou prevenir riscos que possam causar deficiência, além de programas de intervenção precoce para crianças e adultos que se tornem deficientes.

\section{O discurso inclusivo de pessoas com deficiência: história, saber e poder}

Os apontamentos históricos até aqui destacados reforçam a importância de um espaço permanente de discussão acerca da arte de governar populações minoritárias, haja vista, neste caso, o propósito de trazer à reflexão a transitoriedade e a diversidade dos sujeitos pertencentes a esses grupos, bem como a questão da constituição de suas identidades. Sob tal enfoque, tomando-se o projeto foucaultiano como abordagem teórico-metodológica, 
parte-se do princípio de que a caracterização biológica da deficiência de uma pessoa está também condicionada a complexas relações entre os domínios do saber e do poder. Como explica Veiga-Neto (2007), uma analítica do sujeito, nessa perspectiva, não parte do próprio sujeito, mas dos saberes e das práticas discursivas e não discursivas que o envolvem. As práticas e os saberes "uma vez descritos e problematizados poderão revelar quem é esse sujeito, como ele chegou a ser o que dizemos que ele é e como se engendrou historicamente tudo o que dizemos dele" (VEIGA-NETO, 2007, p.113).

Como esse sujeito é significado por práticas discursivas de campos de saberes diversos é também o efeito de complexas relações de poder estabelecidas no âmbito do corpo social. Por isso, os mecanismos de poder encontram-se associados à produção, à acumulação e à circulação de discursos, e não apenas a formas jurídicas (FOUCAULT, 2007a). O sistema de direito, assim, não assegura a legitimidade a ser respeitada pelos indivíduos, mas é um procedimento de sujeição.

Percorrendo, desse modo, o domínio metodológico da arqueogenealogia, empreende-se a busca por identificar mecanismos de poder vigentes em diferentes conjunturas histórico-sociais e econômicas que podem ser tomados como condição para serem formulados saberes sobre o sujeito e o corpo com deficiência. Assim, conforme discutido anteriormente, as condições sociais, morais e éticas que segregam o sujeito com deficiência envolvem o poder disciplinar correspondente à supremacia da raça: mata-se, esconde-se ou segrega-se a deficiência numa espécie de censura biológica. A descoberta, no século XVII, do corpo como objeto e alvo do poder provocou sua submissão ao esquema da docilidade, técnica imposta pela sociedade disciplinar. Uma das principais 
estratégias da disciplina desse período foi permitir o controle minucioso do corpo pela distribuição dos indivíduos num espaço determinado, para assim evitar as aglomerações inúteis e perigosas e satisfazer à necessidade de vigiar, dominar e utilizar os corpos (FOUCAULT, 2005).

A emergência de uma política inclusiva irrompe, pois, do enfrentamento causado pelas consequências físicas e psicológicas que os militares das duas Grandes Guerras. A visibilidade tanto da deficiência congênita quanto da adquirida é a condição necessária para a aceitabilidade desses sujeitos na sociedade da normalização. A busca por tal condição coloca em ação o biopoder, com o objetivo de intervir na vida da coletividade/população no sentido de esta obtenha estados globais de equilíbrio e regularidade. Em resumo, a partir do exercício do biopoder, o que se leva em conta é a vida e os processos biológicos do homem-espécie, ao qual se assegura não a disciplina, mas a regulamentação. A partir desse exercício torna-se possível o estabelecimento de uma relação positiva entre "normais" e "anormais".

Assim, no domínio das deficiências se tem, de um lado, a necessidade de um controle individual, disciplinar - tal como ocorreu, sobretudo, no século XVIII, quando da busca pela sistematização das doenças -, e de outro, o fato de que a deficiência insere-se em processos biológicos mais amplos, abrangendo não apenas o corpo, mas também seus efeitos sobre a população, haja vista que a acessibilidade das pessoas com deficiência a espaços sociais diversificados - como escola, mercado de trabalho e outros - promove o contato com o diferente. Dessa forma, cria-se a condição de possibilidade de a deficiência ser estabelecida no entrecruzamento dos mecanismos de disciplina e de regulamentação. 
Nota-se que a alternância do domínio da deficiência entre a ordem do individual e a do social funciona como dispositivo político, logo, de governamentalidade, criando as condições necessárias para que as etapas de reconhecimento do deficiente promovidas no âmbito internacional por meio de documentos oficiais e leis revelem o processo constitutivo do que vem a ser, na contemporaneidade, a deficiência e os controles sobre ela exercidos - ora sobre o indivíduo ora sobre a população. Nesse movimento, a norma é o elemento que dá suporte tanto à potencialização mútua entre o poder disciplinar e o regulamentador quanto ao funcionamento de ambos, pois,

A normalização disciplinar consiste em primeiro colocar um modelo,
um modelo ótimo que é construído em função de certo resultado, e a
operação de normalização disciplinar consiste em procurar tornar as
pessoas, os gestos, os atos, conformes a esse modelo, sendo normal
precisamente quem é capaz de se conformar a essa norma e o anormal
quem não é capaz. Em outros termos, o que é fundamental e primeiro
na normalização disciplinar não é o normal e o anormal, é a norma.
Dito de outro modo, há um caráter primitivamente prescritivo da
norma, e é em relação a essa norma estabelecida que a determinação
e a identificação do normal e do anormal se tornam possíveis. Essa
característica primeira da norma em relação ao normal, o fato de que
a normalização disciplinar vá da norma à demarcação final do normal
e do anormal, é por causa disso que eu preferiria dizer, a propósito
do que acontece nas técnicas disciplinares, que se trata muito mais de
uma normação do que de uma normalização (FOUCAULT, 2008b,
p.74-75).

Em suma, parte-se de uma norma para distinguir quem se identifica com ela. Em um campo de comparação de atos e de desempenhos, a regra que define a fronteira entre o normal e o diferente é estabelecida pela capacidade física, mental e sensorial dos indivíduos. A metodologia destina-se a determinar níveis de diferenciação e de hierarquização. Neste caso se estabelece a penalidade da exclusão, na qual se demarcam status e privilégios 
para que a ordenação das multiplicidades humanas seja assegurada. Vê-se aí que o foco do poder disciplinar é o desvio, ou seja, tudo o que escapa à regra, à norma. A operação de normalização consiste, pois,

em fazer essas diferentes distribuições de normalidade funcionarem umas em relação às outras e [em] fazer de sorte que as mais desfavoráveis sejam trazidas às que são mais favoráveis. Temos portanto aqui uma coisa que parte do normal e que se serve de certas distribuições consideradas, digamos assim, mais normais que as outras, mais favoráveis em todo caso que as outras. São essas distribuições que vão servir de norma. A norma está em jogo no interior das normalidades diferenciais. O normal é o que é primeiro, e a norma se deduz dele, ou é a partir desse estudo das normalidades que a norma se fixa e desempenha seu papel operatório. Logo, eu diria que não se trata mais de uma normação, mas sim, no sentido estrito, de uma normalização (FOULCAULT, 2008b, p. 82-83).

Importa destacar que um dos operadores fundamentais para tais mudanças é a população (FOUCAULT, 2008b). Por essa razão esta é deixada a circular, desde que sejam anulados os perigos de ela circular. Assim, o que estaria garantido já não seria a segurança do príncipe e de seu território, mas sim, a segurança da população e, consequentemente, de quem a governa. Tratase de delimitar-lhe marcos aceitáveis, em vez de impor-lhe uma lei que diga "não" (FOUCAULT, 2008b). Segundo o mesmo autor, um dos principais elementos que movem essas estratégias de gerência da população é o desejo. É por meio dele que a população se torna penetrável às estratégias do poder. Esse desejo permite a produção de algo interessante e natural para a população, bem como a artificialidade dos meios criados para governá-la. Logo, ao contrário do soberano que dizia "não" aos desejos dos indivíduos, forma-se um pensamento econômicopolítico em que a problemática que se instaura para aqueles que governam é saber como dizer "sim" ao desejo da população. 


\section{Políticas públicas afirmativas, superfície de emergência enunciativa e identidade do sujeito com deficiência}

No âmbito das táticas de intervenção político-econômica do Estado sobre a população, destacam-se as políticas públicas, responsáveis pelo investimento de recursos públicos em ações na realidade social determinadas por diversos grupos políticos e econômicos e por organizações da sociedade civil. Sobre esse processo, importa destacar que a nova configuração social, econômica e política constituída a partir do movimento de globalização reclama por novos elementos na relação entre Estado e sociedade civil. A elaboração e o estabelecimento das políticas públicas dependem, consequentemente, de interesses da expansão do capitalismo internacional, além daqueles originados no contexto nacional e nos vários segmentos que compõem a sociedade civil. Assim, além de supor o investimento de recursos públicos, as políticas públicas são

o resultado da dinâmica do jogo de forças que se estabelece no
âmbito das relações de poder, relações essas constituídas pelos
grupos econômicos e políticos, classes sociais e demais organizações
da sociedade civil. Tais relações determinam um conjunto de ações
atribuídas à instituição estatal, que provocam o direcionamento (e/ou
redirecionamento) dos rumos de ações de intervenção administrativa
do Estado na realidade social e/ou de investimentos. Nesse caso, pode-
se dizer que o Estado se apresenta apenas como um agente repassador
à sociedade civil das decisões saídas do âmbito da correlação de forças
travada entre os agentes do poder (BONETTI, 2006, p. 74).

Nota-se que as políticas públicas não são implementadas somente pelo Estado, mas por vários segmentos da sociedade, e se tornam agentes ao se voltar para grupos notoriamente 
discriminados (pessoas com deficiência, negros, mulheres, homossexuais etc.). Assim, a necessidade de refletir sobre políticas públicas deve-se não só pela sua importância na sociedade, mas também pela sua atuação na constituição das representações e identidades, especialmente a das pessoas com deficiência, em discursos midiáticos.

Enquanto necessidade política, o movimento em prol da inclusão pode ser caracterizado como um fragmento de transformações mais amplas que encontra, na mídia, estratégias para o fortalecimento da singularidade, a valorização da individualidade e da diferença. No que concerne à proposta deste estudo, consideramos que ao ganhar visibilidade na mídia, pela espetacularização do corpo deficiente, as políticas públicas se utilizam de mecanismos que prescrevem à sociedade condutas sociais a serem vividas em seu relacionamento com a deficiência, no cotidiano. É na mídia que a política se "cotidianiza".

$\mathrm{Na}$ prática cotidiana, a atividade política assume a perspectiva de realizar dimensões humanas mais profundas no relacionamento pessoal, como o respeito à diversidade individual e a crítica a formas predeterminadas de conduta. Sem isto, desvincula-se a realidade do dia a dia do espaço de atuação política (MAAR, 2006, p.24).

À mídia, compete subsidiar a veiculação de discursos sobre a inclusão social, uma vez que as imagens, sons e espetáculos nela veiculados "ajudam a urdir o tecido da vida cotidiana, dominando o tempo de lazer, modelando opiniões políticas e comportamentos sociais, e fornecendo o material com que as pessoas forjam sua identidade" (KELLNER, 2001, p. 9). A mídia televisiva, particularmente, é um espaço de circulação de saberes, de instituição modelar de conduta e de constituição identitária. É um dispositivo pelo qual o poder se exerce. Por suas lentes, o que é nela veiculado com regularidade, mesmo que num curto 
espaço de tempo, pode se tornar um espetáculo, uma produção cultural. $\mathrm{O}$ que enuncia pode produzir efeitos de verdade. De forma singular, essa mídia pode ainda construir "uma 'história do presente', simulando acontecimentos-em-curso que vêm eivados de signos do passado", conforme declara Gregolin (2003, p. 96). Por seu funcionamento discursivo, estabelece-se o imaginário de uma identidade social e nacional, uma vez que

\begin{abstract}
a aparente instantaneidade da mídia interpela incessantemente o leitor através de textos verbais e não-verbais, compondo o movimento da história presente por meio da re-significação de sentidos enraizados no passado. Por isso, determinadas figuras cristalizadas na memória coletiva estão constantemente sendo recolocadas em circulação, permitindo os movimentos interpretativos, as retomadas de sentidos e seus deslocamentos. Através desses retornos figurativos, a mídia cria representações que se tornam observáveis e tangíveis (GREGOLIN, 2003, p. 105-106).
\end{abstract}

Como superfície de emergência, a mídia televisiva pode fazer com que enunciados sobre a inclusão da pessoa com deficiência apareçam em sua singularidade, em dada sociedade e em momento histórico determinado, coexistam com outros enunciados, transformem-se e desapareçam. Isso porque a emergência de uma positividade implica diversas transformações sociais, políticas, econômicas e históricas. Nesse processo, essas transformações estão em constanteluta pela fixação de significados e se encontram enredadas nas malhas do poder, proporcionando, assim, que a mídia funcione como um mecanismo pelo qual o poder se exerce e controla os sentidos postos em circulação. Pautando-se nas afirmações de Tasso (2006), os mecanismos que assim funcionam são os que sustentam ou reforçam a presença da atuação da mídia sobre o sujeito-telespectador, tendo em vista que a mídia pode apagar, transformar e consolidar ideais de sujeitos com deficiência delineados pelas propostas inclusivas 
das políticas públicas. Diante disso, para o exame das condições de emergência e de existência desses enunciados, interroga-se sobre 'o que' dizem das pessoas com deficiência; o 'modo como' é dada a constituição identitária dos sujeitos com deficiência, para finalmente se poder explicitar 'por que' o dizer do corpo deficiente é espetacularizado e se esse espetáculo é ou não agradável ao olhar. Por isso se considera que os discursos da mídia televisiva sobre a inclusão das pessoas com deficiência ressignificam a memória social, mítica e histórica desses sujeitos.

Aliadas aos avanços tecnológicos e à mídia, as relações entre sujeito-espaço-tempo podem ser percebidas com mais facilidade, criando possibilidades de "identidades partilhadas". Nas palavras de Hall (2006, p. 74), criam “"consumidores' para os mesmos bens, 'clientes' para os mesmos serviços, 'públicos' para as mesmas mensagens e imagens - entre pessoas que estão [...] distantes umas das outras no espaço e no tempo".

Essa redução no espaço e no tempo instaura a consciência de que o 'pertencimento' ou a 'identidade' são negociáveis e revogáveis, e que as decisões tomadas e a maneira como o indivíduo age são fatores fundamentais para esse pertencimento. Para Bauman (2005), essa questão da identidade surgiu com a necessidade de se criar uma nova ordem, haja vista a desintegração da organização da sociedade, em que aqueles que habitavam a margem invadiram as áreas centrais. Logo, o pertencimento foi colocado como um problema e, sobretudo, como uma tarefa.

As guerras pelo reconhecimento, quer travadas individual ou coletivamente, em geral se desenrolam em duas frentes, embora tropas e armas se desloquem entre as linhas de fronteira, dependendo da posição conquistada ou atribuída segundo a hierarquia de poder. Numa das frentes, a identidade escolhida e preferida é contraposta, principalmente, às obstinadas sobras das identidades antigas, abandonadas e abominadas, escolhidas ou impostas no passado. $\mathrm{Na}$ 
outra frente, as pressões de outras identidades, maquinadas e impostas (estereótipos, estigmas, rótulos), promovidas por 'forças inimigas', são enfrentadas e - caso se vença a batalha - repelidas (BAUMAN, 2005, 44-45).

Hall (2000) argumenta a favor da necessidade de se examinar a identidade como uma prática discursiva que significa ver a identificação

como uma construção, como um processo nunca completado como algo sempre "em processo". Ela não é, nunca, completamente determinada - no sentido de que se pode, sempre, ganhá-la ou "perdêla"; no sentido de que ela pode ser sempre, sustentada ou abandonada. Embora tenha suas condições determinadas de existência, o que inclui os recursos materiais e simbólicos exigidos para sustentá-la, a identificação é, ao fim e ao cabo, condicional; ela está, ao fim e ao cabo, alojada na contingência. Uma vez assegurada, ela não anulará a diferença (HALL, 2000, p. 106).

Importa destacar que nessa perspectiva não se ignora totalmente a tentativa tradicional/ biológica de fixação de identidades, mas a redescoberta do passado é parte do processo de sua construção. Assim, conforme Hall (2000), as identidades precisam sercompreendidas como produzidas em locais históricos e institucionais específicos, porque elas são construídas dentro e não fora do discurso.

Isso posto, nota-se que a mídia televisiva, ao recorrer a determinadas práticas discursivas, cria um espaço que possibilita representar, em sua programação, as rupturas com o modelo tradicional de identificação do sujeito. $O$ funcionamento discursivo da mídia constrói representações da pessoa com deficiência, as quais se constituem pelo deslocamento do passado e possibilitam refletir sobre as práticas discursivas atuais, além de se colocarem à disposição de instituições que promovem a circulação de políticas públicas. 


\section{Segunda parte : : Mídia e estratégias de governamentalidade... \\ Política inclusiva em tela: um gesto de interpretação}

Ao tomar o projeto foucaultiano como método, o estudo teórico-analítico aqui empreendido lança-se ao desafio de afastarse da ideia de modelo, de método englobante, que pode ser aplicado a qualquer objeto. Filiar-se a Foucault significa utilizar-se de seus pressupostos para refletir sobre questões atuais e, assim, transpô-los a outros objetos, mantendo, segundo a proposta do próprio filósofo, a liberdade de pensar e problematizar as revoltas concretas e cotidianas.

Nessa perspectiva, a análise de discursos consistirá na análise de uma dispersão a partir da descrição de acontecimentos discursivos, a fim de buscar as unidades que aí se formam. Isso porque para Foucault, a unidade de discursos sobre um objeto não se dá por uma relação descritível e constante de enunciados sobre ele. A unidade do discurso é constituída por enunciados dispersos e heterogêneos, que coexistem, que se supõem, se transformam ou se excluem.

Dito isso, serão destacados, no entrelaçar das teorizações foucaultianas, alguns dispositivos que forneceram suporte para a interpretação da prática discursivaa alusiva às pessoas com deficiência, especificamente, de uma propaganda que possibilita ilustrar a prática discursiva sobre a inclusão do sujeito deficiente na sociedade atual, a partir das condições de emergência, existência e possibilidade discursiva, auxiliadas pelas questões: o que, como e por que se diz o que diz a respeito da temática.

Veiculada na televisão aberta em 2009, durante a Semana Nacional do Excepcional, a campanha, em vídeo, da Federação das APAES do Paraná é o objeto sobre o qual buscamos 
demosstrar, pelo desenvolvimento do movimento de descriçãointerpretação arqueogenealógico, que a mídia televisiva nacional promove com eficiência a constituição identitária do sujeito por meio de sua governamentalização.

O quadro, a seguir, contempla doze fotogramas. No formato da decupagem dos principais focos ou pontos da sequência narrativa o quadro apresenta, além das doze cenas recortadas do audiovisual em questão, a transcrição da narração em off. 


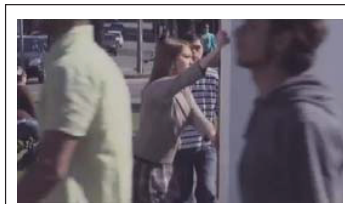

(Cena 1)

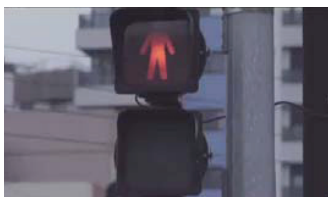

(Cena 4)

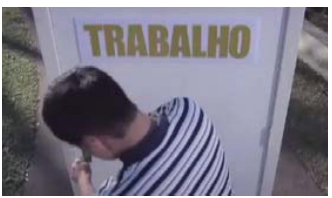

(Cena 7)

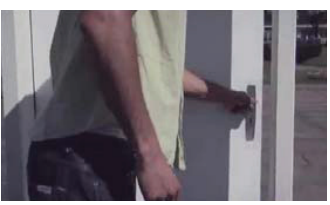

(Cena 10)

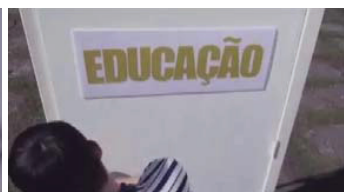

(Cena 2)

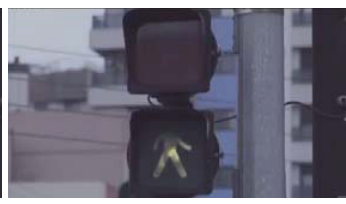

(Cena 5)

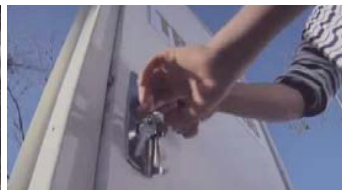

(Cena 8)

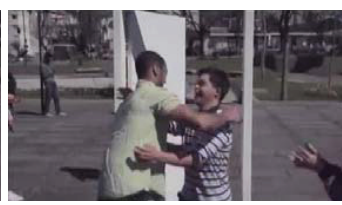

(Cena 11)

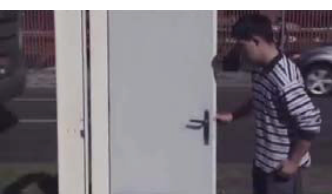

(Cena 3)

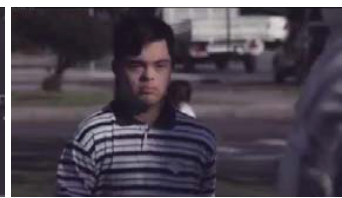

(Cena 6)

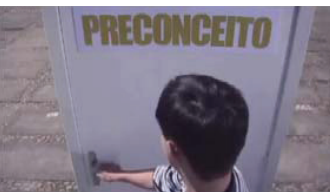

(Cena 9)

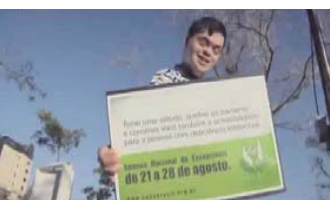

(Cena 12)

Diariamente milhöes de pessoas com deficiência superam limitações, e abrem portas para uma vida melhor. Algumas são mais fáceis de abrir.

Outras só podem ser abertas por dentro.

Dentro de você.

Semana nacional do excepcional.

Federação das APAES do Paraná.

Quadro 1 - Transcrição da propaganda da Semana Nacional do Excepcional (2009). 
A partir desse quadro ilustrativo consideramos que, na instância da visibilidade e do domínio icônico-sensorial, os elementos constitutivos dos doze planos - recortes da imagem em movimento que compõem a sequência narrativa da campanha - podem ser reconhecidos sem dificuldades, graças ao enquadramento das personagens e à perspectiva de tomada da cena, sobretudo porque o cenário compreende um ambiente externo e excessivamente iluminado pela luz solar. Destituído do áudio correspondente à narração em off, o que nele se vê é uma via pública de circulação de pedestres onde se destaca, entre as pessoas que ali circulam, a figura de um jovem portador da Sindrome de Down.

No entanto, os sentidos midiáticos não se dão por acaso. Há um saber técnico que coloca em funcionamento uma linguagem específica para produzir determinados efeitos e não outros. Assim como ocorre com a linguagem verbal, o campo imagético também depende de estratégias e mecanismos próprios a essa linguagem, como cor, perspectiva, textura, tom e movimento. A operacionalização desses elementos, combinada com a dinamicidade empregada na exibição de imagens, palavras e sons, na mídia, produzem sentidos que podem comprovar, sensibilizar ou reforçar uma prática.

$\mathrm{Na}$ sequência das cenas são apresentadas três portas etiquetadas com os enunciados: Educação, Trabalho e Preconceito. Arquitetonicamente, a porta, como uma peça usada em aberturas feitas em paredes para o acesso ou a vedação de pessoas, animais ou objetos a um ambiente, dispõe, em geral, de uma maçaneta para abri-la ou fechá-la. No caso da sequência em questão, as portas encontram-se fechadas e estão nas mãos de algumas pessoas da comunidade que, estrategicamente, deslocam-na e a colocam diante da pessoa a quem se destina. Neste caso, o 
jovem portador de uma deficiência geralmente reconhecida por específicos traços fisionômicos e de conduta.

$\mathrm{Na}$ instância da invisibilidade e de domínio simbólico, as portas correspondem a oportunidades concedidas, quando abertas, ou negadas, quando fechadas. Nessa perspectiva, ambas as direções estão relacionadas com as 'oportunidades' concedidas ou negadas - efeitos possíveis decorrentes do jogo entre as expressões 'superam limitações, 'abrem portas para uma vida melhor', e 'abertas por dentro’.

De início, na narração em off, faz-se menção às milhares de pessoas com deficiência que "abrem portas para uma vida melhor". Por meio do verbo no presente durativo, tal enunciado expressa uma competência do sujeito, ainda que não esteja sendo exercida no momento em que se fala. Tal estratégia pode indicar a luta ininterrupta de pessoas com deficiência para conquistar efetiva igualdade de acesso a bens fundamentais, como a acessibilidade ao ir e vir, a educação e o trabalho, categorias essas também representadas pelos componentes linguísticos que integram as portas.

O jovem para quem se destina a oportunidade aproximase da primeira porta e a abre com facilidade, já que é a porta de acesso à educação, que, pela memória coletiva, é uma das oportunidades de inclusão, uma espécie de panacéia - o remédio para todos os males cujo significado remonta à deusa da cura. É recorrente na sociedade a assertiva de que cabe à escola o papel central "no cuidado com a infância, com a transmissão dos saberes considerados socialmente relevantes, com a formação do cidadão e com a qualificação do trabalhador" (LOMBARDI, 2006, p. 4). 
No cenário político-econômico brasileiro o discurso de 'educação redentora' não é diferente. Devido ao seu caráter a-histórico, esse discurso, de acordo com Lombardi (2006, p. 4), destaca-se na crise de 1929, no Manifesto dos Pioneiros da Educação Nova, na Segunda Guerra, na ditadura militar e, mais recentemente, na Constituinte de 1988 e na Lei de Diretrizes e Bases da Educação Nacional de 1996.

Segundo Tasso (2008), os enunciados que constituem a memória coletiva sobre a educação no Brasil podem produzir os seguintes efeitos:

(I) a escola é para todos; (II) a educação transforma; (III) a educação é a solução para os problemas sociais e econômicos do país; (IV) o desenvolvimento socioeconômico do país depende da educação; (V) a formação educacional é a principal via de ascensão, prestígio e integração no universo dos estratos dominantes; (VI) a educação é um instrumento de inclusão; (VII) a educação desenvolve o ser humano: aprender a conhecer, a fazer, a viver juntos - a viver com os outros -, a ser (TASSO, 2008, p. 52).

Nas condições específicas dessa produção videográfica o jovem com Sìndrome de Down não apresenta dificuldades na abertura da porta identificada pelo termo 'educação'. Cria-se a possibilidade de os sentidos construírem uma imagem positiva de representação de que a educação é uma oportunidade para as pessoas exercerem e usufruírem sua cidadania, portanto é um instrumento de inclusão.

Ao longo da história, a educação das pessoas com deficiência organizou-se de modo especializado e à parte do ensino comum, e sua terminologia e suas modalidades levaram à criação de instituições especializadas no atendimento educacional dessas pessoas. Em específico, no século XX, essas instituições fundamentaram-se na Lei de Diretrizes e Bases da Educação 
Nacional (LDB) n. 4.024/61, que apontava a preferência por integrar os 'excepcionais' ao sistema geral de ensino. Outro marco normativo é assinalado pela "Política nacional de educação especial na perspectiva da educação inclusiva” (BRASIL, 2008). Enquanto a Constituição Federal de 1988 define a educação como um direito de todos e dever do Estado, "O acesso aos níveis mais elevados do ensino, bem como a oferta do atendimento educacional especializado" - isso tudo acrescido de dois importantes documentos que reforçam o dispositivo legal, o Estatuto da Criança e do Adolescente e a LDB n. 9.394/96, os quais, apesar de manterem a concepção tradicional de educação (classes, escolas e serviços especializados), determinam a matrícula de pessoas com deficiência no sistema regular de ensino e definem a oferta de serviços de apoio especializados como de responsabilidade do poder público.

A partir desse movimento conjunto entre o social, o político e o econômico, decorrente da democratização da escola, percebemos que, por meio dessa estratégia, a peça publicitária articulou um campo simbólico cultural e socialmente reconhecido (portas) com a história e a memória, atravessado pelo discurso pedagógico. $\mathrm{O}$ acesso à educação é, assim, uma oportunidade real decorrente do movimento mundial pela inclusão, iniciativa que escapa à mão do Estado, uma vez que na atualidade é implementada também pela luta das próprias pessoas com deficiência. Vale destacar ainda que, embora se trate de uma educação singular, o vocábulo de identificação da porta não está adjetivado, pois por décadas se conhece a denominação: 'educação especial'. Essa estratégia promove o apagamento de uma memória discursiva de segregação do espaço escolar e proclama o quadro atual de inclusão dos alunos deficientes em escolas regulares. 
Essa transposição de lugar da pessoa com deficiência para outro estágio, a do ensino regular (e não mais o especial), pode também ser entendida a partir do código específico da imagem efêmera: o movimento de câmera que retrata a passagem do jovem com Sindrome de Down de um lado para o outro, ao abrir a porta. Não se trata de uma relação dentro/fora real, já que não existem limites arquitetônicos físicos. O realismo da linguagem utilizada repousa em uma organização simbólica que faz sentido para uma dada sociedade - no caso, a brasileira. Isso significa que o acesso à educação é representado de modo próximo ao satisfatório, haja vista que o sujeito-espectador instiga um julgamento de existência na relação exclusão/inclusão na/pela educação.

Por outro lado, após a passagem do jovem pela porta identificada como 'educação', outro elemento visual é colocado em cena como obstáculo: o semáforo. Este representa a passagem de uma norma para outra e tem a função de sinalizar a permissão ou não ao sujeito que transpôs a porta para avançar no trajeto em questão. Dessa forma, mesmo que supere limites (ultrapasse a porta), o sujeito poderá ainda encontrar obstáculos que o impeçam de prosseguir no trajeto de destino.

Nesse domínio de oportunidades, a segunda porta traz como identificação o termo 'trabalho'. Esse enunciado convoca à prática utilitarista do corpo na qual o trabalho se constitui como uma identidade social, já que ele é um dispositivo que possibilita à pessoa com deficiência um espaço de valorização simbólica, consolidado por uma posição político-social de certa independência, devido ao salário que recebe. No entanto, nas cenas da peça publicitária, a essa porta impõe-se uma dificuldade: ela requer uma chave para ser aberta, estratégia que se articula à dificuldade enfrentada pelas pessoas com deficiência de ter acesso ao mercado de trabalho, mesmo sendo este assegurado por lei. 
A legislação implementada em 1999 (art. 93 da Lei n. 8.213/91) prevê uma política de cotas ao estipular pisos percentuais diferenciados de contratação de empregados, a depender do tamanho da empresa. A dificuldade, representada pela chave, pode ser entendida pelo nível de escolaridade alcançado e pela preparação para o trabalho, dois aspectos insuficientes que se reportam às limitações das empresas quanto ao cumprimento dos aspectos legais da contratação sem se preocupar em oferecer condições reais de inclusão no ambiente de trabalho.

A última porta, identificada com o termo 'preconceito', está trancada. O garoto não consegue abri-la sozinho, é preciso que alguém faça isso 'por dentro'. Esta estratégia visual e linguística revela que, apesar de todas as barreiras superadas, há sistemas de valores presentes na sociedade que impedem a democratização dos espaços sociais fundamentada no respeito às diferenças como constitutivas do ser humano, dentre as quais, a condição de ser um negro quem pratica o gesto de abrir a porta, presença que se justifica pelo seu próprio processo de inclusão. Assim, o vetor preconceito constrói o efeito de que, para as pessoas com deficiência terem uma vida melhor e usufruírem de seus direitos básicos, é necessário interrogar não só a evolução das políticas afirmativas relacionadas ao mercado de trabalho ou à educação, mas também as transformações que devem ocorrer na família e na sociedade. É preciso, assim, compreender como o processo inclusivo é produzido nas escolas, nas empresas e na família, interrogando quais os valores que estão sendo atribuídos à diferença, a partir das relações humanas.

Com base nos elementos que compõem os planos de visibilidade e de invisibilidade, o diálogo entre o verbal e o imagético define as estratégias e os mecanismos que conduzem à representação das pessoas com deficiência na peça publicitária 
em questão. Por um lado, verificamos que as cenas privilegiam a representação da acessibilidade legal a determinados espaços sociais, e não da acessibilidade física, enquanto o que está em questão são as oportunidades, amparadas por lei, que podem garantir uma vida melhor às pessoas com deficiência. Por outro lado, a prática inclusiva, mesmo garantida por lei, efetiva-se apenas quando o sujeito 'normal' que passa a conviver com as pessoas com deficiência supera seus próprios preconceitos e atribui valores positivos à diferença.

\section{Considerações finais}

O gesto de interpretação - desenvolvido pelo movimento descritivo-interpretativo arqueogenealógico - da produção videográfica referente à campanha da Federação das APAEs do Paraná na Semana Nacional do Excepcional (2009), exibida na mídia televisiva, permitiu-nos identificar nessa materialidade discursiva o regime do olhar sobre o corpo deficiente na contemporaneidade. A temática do corpo deficiente inscrita nessa materialidade significante deve ser compreendida a partir do preconceito como correlato de poder e como mecanismo de governamentalidade. Nessa perspectiva identifica-se que a posição do sujeito midiático ocupada pelo enunciador coadunase com o discurso de que a acessibilidade aos direitos básicos das pessoas com deficiência é compromisso de todos, mediante a implantação de mudanças na legislação e/ou na arquitetura, e não apenas do próprio deficiente.

Essa posição está em harmonia com o princípio segundo o qual a normalidade do sujeito com deficiência requer uma 
transformação global e imediata dos processos de socialização, e não a mera aceitação de direitos para que possam desfrutar das condições de cidadania. Isso porque a legalidade é, em si, o reconhecimento do preconceito, ou, em outras palavras, o preconceito é a condição de existência das leis. O que vale considerar é que o respeito à acessibilidade depende do Outro para se efetivar. A legalidade é, em si, o reconhecimento do preconceito, ou, em outras palavras, o preconceito é a condição de existência das leis. O que vale considerar é que o respeito à acessibilidade depende do Outro para se efetivar.

As estratégias utilizadas pelo enunciado revelam o exercício de uma linguagem, seja ela verbal ou imagética, vinculado a uma organização simbólica que representa a forma de governar a si mesmo, o Estado e o Outro, ou seja, trata-se, como explica Foucault (2008, p. 132), de "utilizar táticas, muito mais que leis, ou utilizar ao máximo as leis como táticas; agir de modo que, por um certo número de meios, esta ou aquela finalidade possa ser alcançada". Assim, o regime da governamentalidade que se estabelece na materialidade em foco é sustentado pela lei e colocado em funcionamento pelos dispositivos da educação, do trabalho e do preconceito que permitem efetivar-se a normalização da pessoa com deficiência dentro da realidade social, ainda que em níveis diferentes.

\section{Referências}

BAUMAN, Z. Identidade: entrevista a Benedetto Vecchi. Tradução Carlos Alberto Medeiros. Rio de Janeiro: Jorge Zahar, 2005.

BONETTI, L. W. Políticas públicas por dentro. Ijuí: Unijuí, 2006. 
GREGOLIN, M. do R. V. O acontecimento discursivo na mídia: metáfora de uma breve história do tempo. In: - (Org.). Discurso e midia: a cultura do espetáculo. São Carlos: Claraluz, 2003. p. 95-110.

FOUCAULT, M. Vigiar e punir: nascimento da prisão. Tradução Raquel Ramalhete. 30. ed. Petrópolis: Vozes, 2005.

- A arqueologia do saber. Tradução Luiz Felipe Baeta Neves. 7.ed. Rio de Janeiro: Forense Universitária, 2007a.

- A ordem do discurso: aula inaugural no Collège de France, pronunciada em 2 de dezembro de 1970. Tradução Laura Fraga de Almeida Sampaio. 15.ed. São Paulo: Edições Loyola, 2007b (Coleção Leituras Filosóficas). - Segurança, território, população: curso dado no Collège de France (1977-1978). Edição estabelecida por Michel Senellart, sob a direção de François Ewald e Alessando Fontana. Tradução Eduardo Brendão. Revisão da tradução Claudia Berliner. São Paulo: Martins Fontes, 2008 (Coleção Tópicos).

GREGOLIN, Maria do Rosário. O acontecimento discursivo na mídia: metáfora de uma breve história do tempo. In: GREGOLIN, Maria do Rosário (Org.). Discurso e mídia: a cultura do espetáculo. São Carlos: Claraluz, 2003. p. $95-110$.

HALL, S. Quem precisa da identidade? In: SILVA, T. T. da (Org.). Identidade e diferença: a perspectiva dos estudos culturais. Petrópolis, RJ: Vozes, 2000. p. 103-133. - A identidade cultual na pós-modernidade. Tradução Tomaz Tadeu da Silva e Guaracira Lopes Louro. 11. ed. Rio de Janeiro: DP\&A, 2006.

KELLNER, D. A cultura da mídia - estudos culturais: identidade e política entre o moderno e o pós-moderno. Trad. de Ivone Castilho Benedetti. Bauru: EDUSC, 2001.

LOMBARDI. O velho discurso que rege a história da educação. Jornal da UNICAMP, Campinas, 21 a 27 ago., ano XX, no. 334, p. 4-5. Disponível em <http://www.unicamp.br/unicamp/unicamp_hoje/jornalPDF/ju334. html>. 
MAAR, W. L. O que épolítica. São Paulo: Brasiliense, 2006 (Coleção Primeiros Passos).

SILVA, O. M. da. A epopeia ignorada: a pessoa deficiente na História do mundo de ontem e hoje. São Paulo: Cedas, 1987.

TASSO, I. E. V. de S.. Mídia televisiva e políticas públicas de inclusão na Pós-Modernidade: igualdade, solidariedade e cidadania. In: NAVARRO, P. (Org.). Estudos do texto e do discurso: mapeando conceitos e métodos. São Carlos: Claraluz, 2006. p. 129-151.

VEIGA-NETO, A. Foucault \&s a Educação. 2. ed. Belo Horizonte: Autêntica, 2007. 



\section{DOENTE E PECADOR: ECOS DO SÉCULO XIX SOBRE A HOMOSSEXUALIDADE NA IMPRENSA OFICIAL}

(1985-2010)

Alexandre Sebastião Ferrari Soares ${ }^{14}$

O propósito deste artigo é analisar, segundo as concepções da escola francesa de análise do discurso, os sítios de significância (ORLANDI, 1996, p. 15) que foram se estabelecendo na imprensa oficial sobre o homossexual e seu estilo de vida entre a segunda metade da década de 1980, mais especificamente entre os anos de 1985 e 1990 e 20 anos depois, entre os anos de 2005 e 2010.

A proposta, aqui, não é analisar a resistência ao discurso hegemônico sobre os homossexuais na imprensa oficial. Se quisesse, eu o faria, porque outros sentidos estão se estabelecendo sobre e para os homossexuais e seu estilo de vida. O que de fato pretendo é compreender quais sentidos continuam a ecoar na imprensa brasileira de circulação nacional colocando o homossexual na ordem do dia.

Para analisar os primeiros anos do período eleito uso as revistas semanais Veja e IstoÉ e a mensal Superinteressante, e na análise da segunda metade dos anos 10 do século XXI, os jornais

14 Professor do Programa de Pós-Graduação em Letras da Unioeste/Cascavel. 
Folha de São Paulo, O Globo, as revistas Veja, IstoÉ, Época, A Revista (encarte de O Globo), Caros Amigos e Piaui. ${ }^{15}$

Destaco os seguintes autores, usados para a fundamentação teórica dessa pesquisa: PÊCHEUX (1969, 1995, 2002); ORLANDI (1983, 1984, 1988, 1996, 1997, 2001 e 2002); MARIANI (1998, 1999, 2001 e 2005); SOUZA (1997); FOUCAULT (1979, 1987, 1988, 1996, 1999, 2004 e 2005); TREVISAN (2000), dentre outras obras.

A história da homossexualidade se confunde com a história da própria humanidade, e tão natural quanto essa questão é o que se diz (a partir do século XIX, segundo Foucault (1988)) cotidianamente a respeito dos homossexuais: 'doentes', 'anormais', 'pervertidos', 'criminosos', etc. Esses dizeres tornaram-se de tal forma familiares que nada havia a pensar a não ser os sentidos cristalizados a partir deles.

Os homossexuais ${ }^{16}$ apenas ocupavam o espaço da terceira pessoa: falava-se deles: quem eram, como eram, o que faziam e por que o faziam. Falava-se com tanta veemência, que os sentidos se apresentavam fixos, como se colados nas palavras. Talvez esse modo de pensar esteja ligado ao fato de os homossexuais não ocuparem, então, uma posição-sujeito para que pudessem falar e assim fazer outros sentidos.

15 Fiz aqui uma escolha: não estou apresentando neste artigo o que se mostra como resistência a esse/nesse discurso oficial sobre a homossexualidade, mas apenas o que reforça a ideia de que os homossexuais e seu estilo de vida ainda são vistos como anormalidade.

16 Estou especificamente falando da questão da homossexualidade no Brasil (sobretudo da homossexualidade masculina). Nos Estados Unidos, por exemplo, no início dos anos 1970, a história é bastante diferente. Muitos homossexuais começaram a tornar pública a sua vida secreta, passando de uma norma histórica de homossexualidade para outra: "Muitos de nós passamos do vergonhoso homossexual para o assertivo gay e lésbica, tornando o poder dessas palavras o centro de nosso movimento político" (KATZ: 1996, 13) 
As vozes que ocupavam lugares foram se sobrepondo em uma mesma direção a tal ponto que, mesmo para os sujeitos homossexuais, essa memória do dizer ecoava no mesmo sentido. Era discursivamente impossível falar da homossexualidade do homem brasileiro, trabalhador, pai de família, porque faltava lugar para esse discurso. O sujeito homossexual se dizia a partir do que era dito sobre ele: Elvira observou que várias vítimas associam a doença a um "castigo divino" e dizem que, se ficarem boas, deixarão de ser homossexuais.” (Revista Veja no 884, de 14 de agosto de 1985, grifos nossos).

As "vítimas" da observação de "Elvira" no fragmento destacado são homossexuais. Até então (década de 1980), os homossexuais constituíam o grupo potencialmente portador do Human Immunodeficiency Virus (HIV), e a relação entre estar contaminado e ser homossexual (ou promíscuo, pervertido, etc.) era o discurso religioso/cristão por excelência em relação ao contágio do vírus.

O discurso religioso proclama que, ao redimir-se da condição de ser homossexual, o indivíduo se cura da doença própria desse estilo de vida e se torna heterossexual: normal, saudável, sem pecados e, por deslizamento, livre da doença relacionada ao 'pecado' da homossexualidade: "se ficarem boas, deixarão de ser homossexuais".

A atribuição ao divino (que nega a homossexualidade por ser pecado, doença, etc.) de um poder de transformação é recorrente no discurso religioso cristão. Barganha da fé: promessa que se faz em troca de saúde e/ou de um lugar social. Tal como ocorreu com um projeto da Assembleia Legislativa do Rio de Janeiro (rejeitado em 9/12/2004 por 30 votos a 6) que pretendia, com uma ajuda de custo e muita fé, transformar (os doentes) 
homossexuais em heterossexuais ${ }^{17}$. Esse projeto era do deputado Edino Fonseca (PSC/RJ), pastor da Igreja Pentecostal Assembleia de Deus, que, em entrevista à revista Época em 15 de novembro de 2004, ao responder à pergunta sobre como seria feito o tal tratamento, assim se expressou:

Sou pastor evangélico da Assembleia de Deus e como frequentador de templos religiosos observei muitos homossexuais procurando ajuda. Não só devido ao peso de consciência pelos pecados praticados, mas querendo deixar a homossexualidade. $\mathrm{Na}$ Igreja, a alma dessas pessoas é tratada, mas o problema delas está no psiquê (sic). Elas precisam de tratamento psicológico. Nesse caso, para quem tem dinheiro, é só pagar, mas o pobre não tem como resolver o problema e é dever do Estado ajudar a todas as pessoas. (Revista Época, n. 339, de 15 de novembro de 2004, grifos nossos).

Segundo o pastor, são muitos os homossexuais que procuram ajuda nas igrejas, 'não só por conta do peso que carregam em suas consciências' pelos pecados praticados, mas também por quererem deixar de ser homossexuais. A homossexualidade, conforme o religioso (representante de Deus e de uma visão cristã a respeito da homossexualidade), é um peso que se carrega na consciência (e também no imaginário sobre ele) pelo pecado de suas práticas.

'A consciência é o reconbecimento do erro e do mal incorporados e, em vista disso, o tratamento psicológico é fundamental para que se consiga a cura do mal e uma vida de acertos'. O psicológico é o responsável pela doença e, ao mesmo tempo, uma forma de isentar o "doente", já que a vontade está além de suas forças e seu desejo.

17 Nessas condições não é preciso adjetivar os heterossexuais de normais/saudáveis (e talvez não fosse preciso acrescentar os adjetivos anormais/doentes aos homossexuais), porque estava (está) subentendido que eles o são. 
As igrejas evangélicas não aceitam o homossexual; a Católica reconhece o homossexual, mas imputa-lhe a obrigação de não praticar sua sexualidade. A prática é o pecado. Deve-se resistir ao desejo.

A outra pergunta sobre o amor entre pessoas do mesmo sexo, o deputado responde:

ÉPOCA -Dentro da Igreja Evangélica, gays e lésbicas são vistos como pessoas que não estão seguindo a orientação que deveriam, não é verdade?

Fonseca - Sim, claro. Dentro da Igreja Evangélica existe a crença de que todo tipo de amor que não seja entre homem e mulher está fora da normalidade (grifos nossos).

O pastor então 'comenta'18 a afirmação feita pela revista: "SIM, CLARO! É exatamente isso que eles fazem, não seguem a orientação como deveriam e por isso estão em desacordo com o que Jesus ensinou. Normal é o amor entre o homem e a mulher, apenas entre esses".

De acordo com o pastor, dentro das igrejas evangélicas existe a crença de que é natural pensar dessa forma. Anormal seria acreditar que o amor poderia se manifestar de outra maneira.

Num fragmento da revista IstoÉ de 1985, em reportagem que tematiza o mesmo assunto a questão é assim apresentada:

Em alguns pontos do centro da cidade há prostitutos e travestis que, até agora, aparentemente não estão muito preocupados com a doença. "AIDS é coisa de gay", afirma Marcos Antônio Abrão, 25 anos, que se rebatizou “Cláudia Wonder". (Revista Istoé, n 429, de 13 de março de 1985, grifos nossos).

18 Sobre comentário ver FOUCAULT (1996). 
Primeiro cumpre destacar um sentido possível para o 'aparentemente' empregado na sequência reproduzida acima: a manifestação da AIDS não se dá imediatamente ao contato com o vírus. Esse vírus pode alojar-se no corpo durante alguns meses ou anos sem se manifestar. 'Aparentemente', o portador do vírus não apresenta qualquer sintoma da doença. Não estar preocupado "até agora, aparentemente" com a doença pode significar também que as aparências enganam e que mais tarde essa preocupação, assim como a doença, pode vir a manifestarse.

Depois, segundo a própria matéria, gay seria o cliente, em geral, "passivo" nas relações sexuais com os prostitutos ou os travestis; e, ainda de acordo com o artigo, essa tese, a do risco de contaminação apenas em relação aos 'passivos', justifica-se e se sustenta em virtude de que, segundo a reportagem, "os travestis seriam requisitados mais como ativos do que passivos (assim como os prostitutos), portanto estariam menos expostos ao contágio, por esse se dar através do esperma" que se aloja no corpo do cliente, em geral passivo.

Acreditava-se, até então, que quem desempenhava o papel de 'ativo' numa relação estava menos exposto ao vírus porque não tinha contato com o esperma do parceiro (nas relações homossexuais). Descartava-se (ou não se dava tanta importância), na matéria, a contaminação através do sangue ou através do contato da mucosa do pênis (em se tratando dos ativos) com as paredes do ânus. Ser 'passivo' ou 'ativo', na matéria, tem relação direta com a possível contaminação pelo HIV. A questão da virilidade masculina também tem forte apelo na matéria quando esta tenta demonstrar que o heterossexual (no caso, o não homossexual) não corria nenhum risco de contrair a doença. 
É a partir desse novo acontecimento, a epidemia da AIDS (sigla em inglês para a Síndrome da Imunodeficiência Adquirida), que ao homossexual "é permitido um espaço" para dizer, mas esse espaço é restrito às regiões discursivas oficiais sobre AIDS: sexualidade, contaminação, promiscuidade, estilo de vida. Já o discurso médico, ao negar essas outras possibilidades de dizer sobre a homossexualidade, ressalta e evidencia aqueles outros aspectos.

Por que não havia espaço para que outras vozes pudessem dizer? Não havia possibilidade de o homossexual fazer sentido de outra forma que não os já ditos sobre ele? Era como se a sintaxe não fosse capaz de materializar outras construções a respeito da vida fora da heterossexualidade - amor entre homens, por exemplo, ou entre mulheres -, mas apenas o que de alguma forma contribuísse para que a 'verdade' do já construído se sustentasse. Por que não havia espaço na imprensa para outro sentido que não o exótico da doença, o estereótipo da homossexualidade?

Com o advento da AIDS, o panorama mundial em relação à sexualidade, de forma geral, foi bastante alterado, e essa alteração afetou essencialmente a homossexualidade em virtude da relação que se estabeleceu entre a epidemia e os chamados "grupos de risco" (nos quais o homossexual era personagem central).

Desse momento em diante o homossexual passa, de alguma forma, a ocupar um lugar na ordem do dia, não uma posição-sujeito que tivesse direito de fazer outro sentido diante desses acontecimentos, mas um lugar que até o momento não era ocupado. Dá-se então um novo sentido para as questões homoeróticas. Sobre isso, sobre sair do silêncio, Orlandi declara:

Para nosso contexto histórico-social, um homem em silêncio é um homem sem sentido. Então, o homem abre mão do risco da 
significação, da sua ameaça e se preenche: fala. Atulha o espaço de sons e cria a ideia de silêncio como vazio, como falta. Ao negar sua relação fundamental com o silêncio, ele apaga uma das mediações que lhe são básicas. (ORLANDI, 2002a, 37, grifos nossos).

Durante muitos anos, ao homossexual foi imposto o silêncio, um silêncio que não o colocava apenas à margem da sociedade heterossexual, mas o constituía como criminoso/ pecador/doente, a partir dos discursos que podiam lhe dar sentido: os jurídicos, religiosos e médicos; e ele não fazia sentido se não fosse desse lugar já estabelecido.

Paralidarcoma análise do corpus, estabeleci, paralelamente, corpora de textos religiosos cristãos (publicados em livros de história, jornais, folhetos de divulgação, etc.), textos médicos (publicados em revistas especializadas sobre AIDS e em livros que abordam o tema e o discurso direto/indireto de profissionais da saúde) que tratam de questões relacionadas à homossexualidade ou sobre a homossexualidade e sua relação com a AIDS, e ainda textos jurídicos (Código Penal e Código Militar). Esses corpora, no entanto, não são objetos específicos de análise, mas sim, referências para a leitura do corpus desse trabalho.

Segundo Serrani (1988, p. 60 - grifos nossos),

A Análise do Discurso não visa a exaustividade "horizontal", em extensão, mas sim uma exaustividade "vertical", em profundidade, considerada em relação aos objetivos do analista. De maneira oposta a outras áreas de pesquisa, que têm a extensão dos dados como fator constitutivo de seus objetivos, para a Análise do Discurso, a exaustividade extensional torna-se incoerente, na medida em que "todo discurso se estabelece sobre um discurso anterior, apontando para outro. $\mathrm{O}$ que existe não é um discurso fechado em si mesmo, mas um processo discursivo, do qual se podem recortar e analisar estados diferentes. 
Em virtude disso, o recorte temporal que estabeleço para a organização do corpus é suficientemente coerente com a proposta teórica que me auxilia na análise desses dados. Busco as regularidades enunciativas e, para isso, não se faz necessária a quantidade de dados, mas a profundidade deles. Assim as sequências discursivas selecionadas para a análise neste artigo representam as que não foram selecionadas, porque estas são estabelecidas sobre um discurso anterior, em que aquelas também o são. Tinha-se inicialmente a intenção de empregar neste trabalho a palavra "homoerotismo" na mesma acepção de Costa (1992, 21-29), para fazer referência ao que chamamos de 'homossexualismo' na língua coloquial. As razões para isso eram, em primeiro lugar, que 'homossexualismo' remete quem a emprega ao vocabulário do século XIX que deu origem à certa ideia de "homossexual". Outra razão era o fato de que na persistência de tais noções se percebe a manutenção de costumes morais prisioneiros do sistema de denominação preconceituoso que qualifica certos sujeitos como moralmente inferiores apenas pelo fato de apresentarem inclinações eróticas por outros do mesmo sexo biológico. A terceira razão é a necessidade de, ao atribuir outro nome para escapar das significações cristalizadas, poder desconstruir conceitos dicionarizados e apontar para a possibilidade de outros sentidos na língua: paráfrase e polissemia, que não tenham o ranço moralista que perfazem esses nomes.

Quando emprego a palavra homoerotismo refiro-me meramente à possibilidade que têm certos sujeitos de sentir diversos tipos de atração erótica ou de se relacionar fisicamente de diversas maneiras com outros do mesmo sexo biológico. Em outras palavras, o homem homoeroticamente inclinado não é, como facilmente acreditamos, alguém que possui um traço ou conjunto de traços psíquicos que determinariam a inevitável e necessária expressão da sexualidade homoerótica em quem quer que os possuísse.

$[\ldots]$ 
Melhor seria dizer, então, que o emprego do termo visa sobretudo distanciar o interlocutor de sua familiaridade com a noção de "homossexualidade". Tal familiaridade pode fazê-lo traduzir o que pretendo dizercomuma nova reavaliação moraldo "homossexualismo". Não é esse meu intento. Tenho a intenção de mostrar que o "homem homossexual" nada mais é que uma realidade linguística, e não uma realidade natural. É uma forma de subjetividade que como qualquer subjetividade pode ser historicamente circunscrita em seu modo de expressão e reconhecimento. $E$, assim como em épocas precedentes outras crenças linguísticas conferiram foros de realidade natural ou universal a certas formas de subjetivação, em nossa época fizemos da "homossexualidade" uma "realidade psíquica e sexual" que nos aparece como um modo de ser do sujeito, natural e universalmente necessário, e não culturalmente arbitrário. (COSTA, 1992, p. 22-23, grifos nossos).

No entanto, tal opção não foi mantida neste trabalho por se considerar que, apesar da larga vantagem do significado do termo 'homoerotismo' (citado acima), o emprego de uma palavra por outra seria mais improdutivo que vantajoso, em virtude de 'homoerotismo' não ser tão impactante quanto 'homossexualidade', termo carregado de significações.

'Homossexualidade' tem história, posição política, e dessa forma seu sentido não apenas marca outras formas de significar o homossexual, mas aponta para outros sentidos possíveis nesse embate de forças entre dizeres e a cristalização de conceitos. O que falta ao termo 'homoerotismo' proposto por Costa (1992)? Estaria ainda vazio de significados, não dá sentido, não conta nenhuma história, porque "para que uma palavra faça sentido é preciso que ela já tenha sentido" (ORLANDI, 1996, p. 71). Em síntese, qualquer substituição pode parecer frágil se for meramente linguística, pois cada tempo tem a sua maneira de nomear e interpretar o mundo.

Todas as acepções para definir as relações entre dois homens ou duas mulheres continuarão carregadas de elementos 
pejorativos enquanto a sociedade mantiver a tendência de estigmatizar esse tipo de inclinação (TREVISAN, 2000).

Dessaforma, os termos 'homossexualidade'e 'homossexual' serão empregados neste trabalho para definir homens (mulheres) que desejam outro(a)s homens (mulheres) porque por enquanto a língua nos permite apenas isto, e diante da necessidade de dar nomes, como não se pode dizer tudo, estas são as nossas possibilidades.

A primeira matéria ${ }^{19}$ dos anos 10 deste século foi veiculada no dia 12 de julho de 2009, no jornal O Globo, no caderno OMundo, página 34, sob o título "Índia: reação contra descriminalização de gays - astrólogo revoltado com decisão histórica aciona a Suprema Corte, que colhe o pedido":

RIO - O homossexualismo está no centro de uma batalha verbal e judicial na Índia, conforme reportagem da correspondente Florência Costa, na edição de domingo do GLOBO. No início do mês, o Tribunal de Justiça de Délhi descriminalizou o sexo entre gays - uma decisão histórica no país conservador, em que o tema é um grande tabu. (grifo nosso).

Primeiramente, o que se percebe é que 'homossexualismo' continua sendo reproduzido, mesmo depois da resistência ao termo. Ele retoma um discurso do século XIX (médicos higienistas) cujo cerne seria, tal como 'alcoolismo', 'reumatismo' e 'nanismo' (entre tantos outros), aproximar o homossexual de uma condição patológica. O sintagma é naturalizado na matéria de forma a não emergir outro sentido para o homossexual além dos cristalizados.

19 Para este artigo selecionei apenas duas matérias referentes ao período de 2005-2010, uma publicada pelo o jornal O Globo e a segunda pela Folha de São Paulo em 2009. 
Nos EUA, em 1980, a Associação Psiquiátrica Americana deixou de considerar a homossexualidade como uma doença, e aqui no Brasil, em 1985, o Conselho Federal de Medicina adotou o mesmo procedimento. Apesar disso, a voz dos grupos em defesa dos direitos dos homossexuais é silenciada e o embate entre formações discursivas é ignorado.

Um dos mais famosos astrólogos hindus do país, Sushil Kaushal,
acionou a Suprema Corte - a instância máxima do Judiciário indiano
- contra a decisão, alegando que "o sexo gay não é natural". O
astrólogo afirma que a legalização do homossexualismo é uma
agressão aos valores e à cultura da sociedade indiana. Ele
argumenta que $80 \%$ dos indianos permaneceram no início do século
XX do ponto de vista social e cultural. O astrólogo lembra que, desde
a descriminalização do homossexualismo, já houve sete casamentos
gays em vários pontos do país. Isso - segundo ele - coloca em risco
a instituição do casamento - uma das mais sólidas e tradicionais
na Índia. (grifos nossos).

Os mesmos sentidos da década de 80 do século passado sobre 'agressão aos valores e à cultura' ou o 'risco que se coloca ao casamento' como uma instituição sólida e tradicional, seja na Índia seja em outras partes do mundo, continuam reverberando na imprensa.

Embora na sequência discursiva (doravante SD) se fale sobre 'casamentos gays' e dessa forma venha à tona outro sentido sobre as relações homoafetivas, parece-me que 'casamento gay' e 'casamento como instituição sólida e tradicional' têm valores distintos.

Tabu, repressão, antinatural, agressão aos valores e à cultura, pôr em risco a instituição do casamento, anormalidade, sexo com animais, contra a tradição do casamento, doença que pode ser curada com meditação e ioga, desequilíbrio hormonal, sentimento do amor focado na direção errada, queda no 
crescimento da população, privação do seu potencial de recursos humanos, campanha contra a legalização do homossexualismo, líderes de várias religiões, código penal que pune a prática sexo sexo entre pessoas do mesmo gênero, dez anos de prisão, mesmo patamar da pedofilia e o sexo com animais são algumas das expressões ${ }^{20}$ que surgem nessa matéria. Todas trazem os sentidos de que a homossexualidade carrega consigo o estigma do pecado, da doença e do crime, pois colocar-se favorável ao homossexual põe à prova certos valores morais, religiosos e jurídicos. A homossexualidade é uma doença que se deve 'curar', porque, como a pedofilia e a zoofilia, é uma aberração.

Esses sentidos eram recorrentes naquele corpus da década de 1980: o homossexual não tinha voz, ele era apenas falado, e quando falava, fazia-o para reproduzir os mesmos sentidos veiculados naqueles meios de comunicação. Um forte argumento dos líderes religiosos judaico-cristãos era que a instituição casamento corria risco com o fato de serem aceitas as relações homoafetivas. Além disso, ser contra as relações homossexuais era justificado pelo fato de que tais relações não podiam, por questões biológicas, gerar procriação. Nesse modo de pensar, o sexo é tido quase sempre como forma de perpetuar a família, e nunca como fonte de prazer.

A segunda matéria foi publicada no dia 14 de julho na Folha de São Paulo, em uma entrevista com uma psicóloga que 'promete', por meio de 'seus recursos terápicos, curar os homossexuais'. Nela se observa o mesmo discurso do pastor veiculado pela revista Época em 2004:

20 Palavras ou expressões que são usadas para significar, neste caso, os homossexuais, criam regiões discursivas em torno dessas relações. 
'Psicóloga' e 'evangélica' afirma que a 'homossexualidade é uma doença' e, portanto, 'passível de cura'. Além disso, na entrevista concedida pela profissional, 'ela faz uma relação direta entre pedofilia e homossexualidade', de forma que a sociedade se ponha em alerta em relação aos homossexuais e seu estilo de vida.

De conformidade com a psicóloga, existe 'uma espécie de acordo social' para que a homossexualidade se estabeleça impositivamente em nosso meio. Ela afirma ter 'curado' por volta de 200 homossexuais através de sua terapia. Além disso, afirma que á maioria dos homossexuais foi abusado sexualmente na infância'e que isso os teria levado à prática homossexual.

Assim, as denominações produzidas nessa entrevista saem do lugar-sujeito ocupado pela psicóloga neopentencostal. Ela se diz religiosa e também afirma que suas práticas são mediadas por sua religião.

São as seguintes as denominações produzidas pela psicóloga na matéria da Folha:

teria atendido e curado centenas de pacientes gays em 21 anos; a homossexualidade é uma doença; pessoas abusadas na infância e na adolescência; tenho minha experiência religiosa; tudo que faço fora do consultório é permeado pelo religioso; sinto-me direcionada por Deus; Movimento Pela Sexualidade Sadia; meios para a mudança de orientação sexual; reunir alguns ex-gays e psicólogos amordaçados para protestar contra a censura; é a Inquisição para héteros; doença que estão querendo implantar em toda a sociedade; há um grupo com finalidades políticas e econômicas que quer estabelecer a liberação sexual; inclusive o abuso sexual contra criança; implantar a ditadura gay; projetos no Congresso para cercear o direito de expressão; eles foram queimados na Santa Inquisição; querem criar a Santa Inquisição para heterossexuais; é um tratamento normal; vários teóricos declaram que a homossexualidade é um transtorno; a psicanálise a considera como uma perversão; a pessoa vai compreendendo porque ficou presa àquele tipo de comportamento e vai conseguindo sair; não há nada 
de tão misterioso e original na minha prática; sou uma profissional comum.

Todas essas palavras e/ou expressões são afirmações negativas sobre o lugar que o homossexual/a homossexualidade 'deve' ocupar em termos de lugar social, porque ele e seu estilo de vida são doenças, porque não fazem uso de uma prática sexual saudável, como os heterossexuais, porque, segundo a psicanálise (a quem recorre como autoridade para comprovar/reforçar os sentidos que produz), a homossexualidade é uma perversão.

Tanto nessas denominações quanto naquelas do O Globo, a homossexualidade é comparada ao abuso sexual de crianças, e isso provoca, em termos de efeitos de sentido, um apelo social para que não se permita a aprovação da criminalização da homofobia, entre outros aspectos já citados ao longo do texto. Essas matérias trazem novamente os sentidos que se colaram ao homossexual no início da década de 1980 com a AIDS, porque as formações discursivas religiosa e médica estão produzindo aqui seus efeitos de sentido.

Se, ao serem classificadas como doenças, certas práticas sexuais responderam à demanda de uma moralidade social mais ampla, seu desaparecimento enquanto tal, mesmo tendo se dado em condição homóloga - de pressão por parte de movimentos sociais - não parece corresponder a uma modificação profunda daquelas condições de produção (na década de 1980) de sentido moralizante - agora caracterizadas por um suposto estado de tolerância sexual generalizada.

Parece-me que o que se diz sobre a homossexualidade (pelo menos no discurso que se oficializa nos meios de comunicação) não é muito diferente do que se dizia na década de 1980. Surgem 
outras vozes de outros lugares, num aberto confronto de sentidos.

'Comportamento de desvio' é como a Igreja Católica adjetiva a prática homossexual, ratificando, assim, a ideia de que os homossexuais vivem em pecado, destoam do ideal católico-cristão, são doentes, imorais. Além disso, afirma ser esse comportamento uma ameaça à sociedade, no entanto não especifica a que sociedade está se referindo. Sabe-se, por deslizamento de sentido, que essa sociedade não considera $\mathrm{o}$ homossexual parte integrante dela, de forma a significar que a posição-sujeito ocupada pelo homossexual não corresponde a um lugar que faça sentido nessa região discursiva.

Aqueles dizeres sobre a homossexualidade partem de uma formação discursiva heterogênea: suas características são diversas, mas convergem para um sentido hegemônico: ou seja, são dizeres médicos, jurídicos e religiosos que desqualificam a homossexualidade, mantendo um 'já-dito’ sobre essa orientação sexual e relacionando os homossexuais à AIDS durante esse período.

As SDs retomam numa espécie de 'corrente linguística' em que os conceitos e as verdades do século XIX dos médicos higienistas e os valores religiosos são a todo tempo rememorados, fazendo amanutençãodesses sentidos (quandoessediscurso afirma ser a doença uma espécie de punição por esse comportamento, que ofende a Deus). Isso quer dizer que a produção de certos imaginários está vinculada a uma determinada 'Interpretação' (em maiúscula para significar sentido específico numa formação discursiva dada). É como se sentidos determinados se colassem nas palavras em certas condições de produção sócio-histórica, 
definindo o que deve ser dito daquele lugar e quem pode falar de certa posição-sujeito.

A Interpretação torna-se natural (e é da ordem do impossível que outra possa fazer sentido). Não há, como já disse, estranhamento ao se colar o valor (no caso, já estabilizado) de causalidade entre a homossexualidade e a doença: a (im)possível pergunta “Como é que isso não poderia ser apenas isso?" nunca se realiza nessas condições de produção.

O discurso jornalístico tem papel fundamental nessa construção de sentido entre o homossexual e a doença, pois, sob uma ilusória pretensão de neutralidade e veracidade, difunde, sobretudo, os discursos religiosos, os quais sustentam como própria do homossexual e de seu estilo de vida a responsabilidade por algumas práticas.

\section{Referências}

AUTHIER-REVUZ, J. Hétérogénéité montrée et hétérogénéité constitutive: élements pour une approche de l'autre dans le discours. Em DRLAV - Revue de Linguistique, 1982.

CADERNOS PELA VIDA Especial: 20 anos de AIDS. São Paulo: Gplsp, 2001.

CHAUÍ, Marilena. Repressão sexual essa nossa (des)conhecida. $7^{\text {a }}$ ed São Paulo: Brasiliense, 1984.

CORRÊA, Marilena Villela. Sexo, Sexualidade e Diferença no Discurso Médico: Algumas reflexões in A Sexualidade nas Ciências Humanas. LOYOLA, Maria Andréa (org.). Rio de Janeiro: EdUERJ, 1998, p.69-91. 
COSTA, Jurandir Freire. Sem fraude nem favor: estudos sobre o amor romântico. Rio de Janeiro: Rocco, 1999. - A inocência e o vício - Estudos sobre a homossexualidade. Rio de Janeiro: Relume-Dumará, 1992.

FOUCAULT, Michael. Microfisisica do poder. Rio de Janeiro: Edições Graal, 1979. . Vigiar e punir: nascimento da prisão. Petrópolis: Vozes, 1987. . História da sexualidade I: a vontade de saber. Rio de Janeiro: Edições Graal, 1988. . A ordem do discurso. São Paulo: Edições Loyola, 1996. Em defesa da sociedade: Curso no Collège de France (1975-1976). São Paulo: Martins Fontes, 1999. . Ética, sexualidade, politica. Rio de Janeiro: Forense-Universitária, 2004. 2008. - Arqueologia do saber. $7^{\mathrm{a}}$ ed. Rio de Janeiro, Forense-Universitária, GADET, Françoise \& HAK Tony (orgs). (1990). Por uma análise automática do discurso; uma introdução à obra de Michel Pêcheux. Campinas: Editora da Unicamp, 2005.

GOLDENSON, Robert M. \& ANDERON, Kenneth N. Dicionário de sexo. São Paulo: Ática, 1989.

GRAÑA, Roberto B. (org). Homossexualidade: formulaçoes psicanaliticas atuais. Porto Alegre: Artmed, 1998.

GREEN, James N. Além do carnaval: a homossexualidade masculina no Brasil do século XX. São Paulo: Editora da UNESP, 1999.

HENRY, Paul. A ferramenta imperfeita: língua, sujeito e discurso. Campinas:

Editora da Unicamp, 1992.

INDURSKY, Freda. A fala dos quartéis e as outras vozes. Campinas: Editora da Unicamp, 1997. 
INDURSKY, Freda \& FERREIRA, Maria Cristina Leandro (orgs.). Os múltiplos territórios da Análise do Discurso. Rio Grande do Sul: Editora Sagra Luzzatto, 1999.

KATZ, Jonathan Ned. A invenção da heterossexualidade. Rio de Janeiro: Ediouro, 1996.

MARIANI, Bethania O PCB e a imprensa - os comunistas no imaginário dos jornais 1922-1989. Rio de Janeiro: Revan, 1998.

. Sobre um percurso de análise do discurso jornalístico - A Revolução de 30. In: INDURSKY, Freda \& FERREIRA, Maria Cristina Leandro (orgs.). Os múltiplos territórios da Análise do Discurso: Rio Grande do Sul: Editora Sagra Luzzatto, 1999.

- A institucionalização da língua, história e cidadania no Brasil do século XV TII: o papel das academias literárias e da política do Marquês de Pombal. In: História das Ideias Linguísticas - construção do saber metalinguístico e constituição da língua nacional. ORLANDI, Eni P. (org.). Campinas: Pontes, 2001.

. (2005). Para que (m) serve a psicanálise na imprensa? Disponível em: http://www.geocities.com/gt_ad/bethania.doc

ORLANDI, Eni. A linguagem e seu funcionamento: as formas do discurso. São Paulo: Brasiliense, 1983.

- "Segmentar ou recortar". In Linguística: questões e controvérsias. Série

Estudos 10. Publicação do Curso de Letras do Centro de Ciências Humanas e Letras das Faculdades Integradas de Uberaba. Uberaba, 1984, p. 9-27.

. Discurso e leitura. São Paulo: Cortez, Editora Unicamp, 1988.

. Interpretação: autoria, leitura e feitos do trabalho simbólico. Petrópolis:

Vozes, 1996.

(org). Gestos de leitura - da bistória no discurso. Campinas: Editora da Unicamp, 1997. - Análise de discurso: princípios e procedimentos. Campinas: Pontes, 2001a. 
. Discurso e texto: formação e circulação dos sentidos. Campinas: Pontes, $2001 \mathrm{~b}$.

. As formas do silêncio. Campinas: Editora da Unicamp, 2002a.

Lingua e conhecimento linguistico: para uma história das ideias no Brasil. São

Paulo: Cortez, 2002b.

PÊCHEUX, Michel. Semântica e discurso: uma crítica à afirmação do óbvio.

Campinas: Editora da Unicamp, 1995.

O discurso - Estrutura on Acontecimento. São Paulo: Pontes, 2002.

RICHARDS, Jeffrey. Sexo, desvios e danação: as minorias na Idade Média. Rio de Janeiro: Jorge Zahar, 1993.

RIOS, Roger Raupp. A Homossexualidade no direito. Porto Alegre: Livraria do Advogado, 2001.

SERRANI, Silvana M. A linguagem na pesquisa sociocultural: um estudo da repetição em discursividade. Campinas: Editora da Unicamp, 1993.

SONTAG, Susan. 3 ed. A doença como metáfora. São Paulo: Graal, 1984. . A AIDS e suas metáforas. São Paulo: Companhia das Letras, 1989.

SOUZA, Pedro de. Confidências da carne. Campinas; Editora da Unicamp, 1997.

SPENCER, Colin (1999). Homossexualidade: uma história. 2ed. Rio de Janeiro: Record.

TREVISAN, João Silvério. Devassos no paraíso: A homossexualidade no Brasil, da colônia à atualidade. Rio de Janeiro: Editora Record, 2000.

ULLERSTAM, Dr. Lars. As minorias eróticas. Rio de Janeiro: Lidador, 1967.

VAINFAS, Ronaldo. Trópico dos pecados: moral, sexualidade e Inquisição no Brasil. Rio de Janeiro: Nova Fronteira, 1997.

O Globo de 12 de junho de 2009.

Folha de São Paulo de 14 de julho de 2009. 
Revista Época, ed. 339, de 15 de novembro de 2004.

Revista Veja no 884, de 14 de agosto de 1985.

Revista Istoé no 429, de 13 de março de 1985. 



\section{Terceira parte}

Sujeito, produção de identidades e subjetivação 



\section{O "SAPO BARBUDO" E O "LULINHA PAZ E AMOR": AS IDENTIDADES DE LULA CONSTRUIIDAS PELA MÍDIA NA CAMPANHA DE 2002 Elaine de Moraes Santos ${ }^{21}$, Edson Carlos Romualdo ${ }^{22}$}

O arquivo não é descritível em sua totalidade; e é incontornável em sua atualidade. Dá-se por fragmentos, regiões, e níveis, melhor, sem dúvida, e com mais clareza na medida em que o tempo deles nos separa: em termos extremos, não fosse a raridade dos documentos, seria necessário maior recuo cronológico para analisá-lo (FOUCAULT, 1997a, p. 150).

\section{Considerações iniciais}

Pós-Modernidade, Modernidade Tardia e Modernidade Líquida são três designações que referenciam um período marcado por uma expressiva descentralização identitária. Em todos os espaços de nossa era a organização social ganhou novos contornos e fez emergir um sujeito fragmentado e sem identidade fixa. Na política esse cenário é ainda mais significativo. Com vistas à disputa pelo poder, a multiplicidade de interesses e ideologias

21 Doutoranda do Programa de Pós-Graduação em Letras da UEM.

22 Professor do Departamento de Letras e do Programa de Pós-Graduação em Letras da UEM. 
com que a política se configura garantiu-lhe, durante longo tempo, o caráter de atuar pelo convencimento e pela sensibilização no corpo a corpo social. $\mathrm{Na}$ primeira metade do século $\mathrm{XX}$, no entanto, o advento de diversas mídias levou o discurso político a uma reconfiguração, já que, ambientada pela mídia, a fala pública passou a ser, na tela, ou em outras materialidades, uma prática antiga que adquiriu especificidades diferentes e essenciais a uma política de natureza pós-moderna.

Pensar a organização social dessa política nos permite recuperar uma questão norteadora mais presente em Santos (2009), a qual, no interior da discussão que agora empreendemos, ganha uma dimensão pontual: a de como historicizar a discursivização identitária do sujeito político pós-moderno. A partir dessa premissa, focamos neste texto uma inquietação tradicional entre os pesquisadores que exploram, em diversas áreas do conhecimento, a fluidez e as especificidades que marcam a sociedade pós-moderna: a descentralização identitária do sujeito (político). As bases para essa escolha encontram motivação na hipótese de que num processo político-eleitoral as práticas discursivas midiáticas podem disseminar a imagem negativa de um sujeito político caracterizado por múltiplas identidades.

A corrida presidencial de 2002 configurou-se na história do País como um dos acontecimentos mais multifacetados da política brasileira, especialmente pela forma como este foi midiatizado e espetacularizado nacional e internacionalmente. A discursivização do olhar midiático sobre esse evento público destacou-se por uma intensa produção de matérias jornalísticas acerca de um sujeito político específico: o candidato Luiz Inácio Lula da Silva, do Partido dos Trabalhadores (P'T). 
No limiar da dispersão inerente ao cenário político-eleitoral em destaque, as diversas vozes midiáticas fomentaram a hipótese de que Lula, cansado de representar oposição ao governo vigente e de um histórico de derrotas nas urnas, assumia, em 2002, um perfil estético-corporal e discursivo amplamente elaborado para vencer as eleições. Nessa direção, a ideia dessa nova identidade de Lula foi vastamente difundida pela mídia em questionamentos sobre sua proposta de governo, suas alianças político-partidárias e, principalmente, sobre a imagem corporal com que o petista figurou na campanha presidencial, conduzida com a assessoria do marqueteiro Duda Mendonça.

Destarte, os efeitos de sentido produzidos pela prática discursiva da mídia brasileira denunciam a convivência de duas identidades apontadas como contraditórias, por demarcarem um antes e um depois na carreira do candidato: o "Sapo Barbudo" e o "Lulinha Paz e Amor". Com o intuito de analisar o processo de discursivização dessas identidades, realizamos um gesto de interpretação das regularidades instauradas em três mídias impressas de considerável circulação nacional: os semanários Época, IstoÉ e Veja. A investigação dos mecanismos de construção desses discursos está ancorada nos pressupostos teórico-metodológicos da Análise do Discurso de linha francesa (doravante AD), especialmente a partir do acionamento das noções de "arquivo", "enunciado", "formação e regularidade discursiva" - essenciais à adoção do método arqueológico tal como proposto por Foucault (1997a). Numa interlocução entre a perspectiva discursiva e alguns aportes de teóricos que abordam a questão da identidade, nosso texto também dialoga com os Estudos Culturais, sobretudo com as contribuições de Hall (2006) e Bauman (1997). 
A partir desse recorte epistemológico e de posse de um objeto discursivo formado, em pesquisa anterior, pelas 154 edições das três revistas publicadas em 2002, delimitamos como corpus de análise para este trabalho duas edições em que o petista foi reportagem de capa do período eleitoral, uma da revista IstoÉ e uma da Veja.

Nosso gesto de interpretação tem como objetivos: a) mostrar como se publicizou a ideia da dupla identidade de um candidato-corpo do PT; e b) a partir da discursivização das identidades de Lula pela imprensa, esboçar uma possibilidade de explicação para a fragmentação identitária do sujeito político pós-moderno. Por essas vias, nossa análise é estruturada em duas etapas, nas quais conceitos e métodos vão sendo requisitados oportunamente. Em um primeiro momento debruçamo-nos sobre os efeitos de sentido inerentes aos enunciados que, na reportagem de capa das duas edições, disseminam a ideia de que duas identidades contraditórias marcaram a carreira política do petista rumo à presidência. Depois descrevemos, histórica e sucintamente, o surgimento dessa prática/política de contenção gesto-corporal adotada por Lula em 2002 como fruto de uma organização social pós-moderna na qual o corpo político é a base imperatriz dos holofotes midiáticos.

\section{Análise do Discurso e Estudos Culturais: a questão da(s) identidade(s)}

O berço da AD francesa, a França dos anos 60, passou por um importante momento histórico, em que dois diferentes 
discursos circulavam por entre a sociedade: o discurso reformista e o discurso revolucionário. Neste contexto, Courtine (2006) sugere a motivação para que o discurso político viesse a se tornar o principal objeto de estudos da nova ciência da linguagem que despontava. Os principais objetivos das primeiras análises consistiam no fornecimento de mecanismos que distinguissem os discursos provenientes dessas duas filiações partidárias francesas e na elaboração de uma estratégia de leitura da política.

Atualmente, em vista dos gestos de interpretação que esse campo do saber permite trilhar, é quase impossível mergulhar no universo discursivo sem se deparar com a análise da multiplicidade de identidades subjacentes à sociedade contemporânea. De acordo com Hall (2006), estuda-se a identidade na Pós-Modernidade para se compreender a sociedade em diversos aspectos tanto quanto para entender a si mesmo. O debate nessa área tem frutificado especialmente em pesquisas que buscam compreender a chamada "crise de identidade" do sujeito pós-moderno:

A assim chamada "crise de identidade" é vista como parte de um processo mais amplo de mudança, que está deslocando as estruturas e processos centrais das sociedades modernas e abalando os quadros de referência que davam aos indivíduos uma ancoragem estável no mundo social. (HALL, 2006, p. 7).

A literatura de Foucault, tão vasta quanto variada, também se situa num ponto de intersecção entre os temas que abordam o homem, entre os quais a questão do discurso tornou-se indispensável, já que o autor considera que todas as "coisas" do mundo são construídas por práticas discursivas. De acordo com Hall (2006), a obra foucaultiana se situa como o quarto eixo de descentramento principal da identidade e do sujeito, sobretudo ao tratar do poder disciplinar do século XIX. Assim, 
as pesquisas foucaultianas giram em torno do sujeito, dos modos de subjetivação e da relação entre linguagem, história e sociedade - sobretudo pelo encontro das noções de poder, sujeito e verdade.

No presente estudo realizamos a leitura de Michel Foucault a partir do que se costuma chamar de 'sua fase arqueológica', pois é nesse período que ele apresenta a relação do enunciado e da função enunciativa com o sujeito, dada a relação estreita que há entre o homem e o discurso. O sujeito foucaultiano é entendido como dispersão, mesmo com a ilusão de unicidade do dizer que é inerente aos indivíduos. Em sua Arqueologia do saber (1997a) o filósofo francês apresenta as especificidades que norteiam a sua análise histórica acerca do caráter subjetivo da sociedade ocidental que investiga. Para o autor, a noção de sujeito é perpassada por diferentes práticas discursivas: sem autonomia quanto à sua fala e com posição discursiva enredada na história, o sujeito ocupa sempre um lugar próprio na ordem dos discursos.

$\mathrm{Na}$ concepção de Foucault (1997a), o discurso é um elemento único, é um conjunto de enunciados que podem pertencer a campos diferentes, mas estão sujeitos às mesmas regras de funcionamento. $\mathrm{O}$ método arqueológico consiste, então, na interrogação desses ‘já-ditos’ em seu nível de existência, isto é, na multiplicidade de discursos que revelam o sujeito como um elo entre enunciado e arquivo que se configura a partir de uma relação entre saber e poder.

Assim, pelo método arqueológico que utilizamos neste trabalho, centramos esforços em perceber os deslocamentos das práticas discursivas analisadas e os efeitos de sentidos subjacentes a tais deslocamentos, pois na arqueologia foucaultiana não 
se acredita em uma verdade absoluta ou na possibilidade de uma interpretação verdadeira da história. O papel do analista, especialmente quando debruçado sobre textos midiáticos, é, nessa ótica, o de descrever os mecanismos que, quando acionados, são responsáveis pela produção de um "efeito de verdade" 23 . Assim, em nossa investigação ganha destaque a produção de um efeito de contradição na discursivização de duas identidades para um sujeito político pós-moderno, Lula, inserido no interior de uma sociedade líquida.

Os Estudos Culturais também compreendem a identidade como uma construção discursiva que só produz efeitos de sentido quando situada historicamente no interior dos discursos sociais em que é produzida. Desde o seu nascimento na Inglaterra, sua expansão pela América do Norte e sua chegada ao Brasil, esse campo tem fomentado discussões e teorizações sobre a(s) cultura(s) e sobre a construção de identidades com base em gênero, sexualidade, raça, etnia e relações de poder entre os indivíduos e/ou grupos culturais. No geral, suas reflexões são situadas na confluência de vários campos de conhecimento, buscam inspiração em distintas teorias e rompem com lógicas científicas antes cristalizadas.

O diálogo entre esses dois aportes teóricos se justifica pelo fato de que, se para a $\mathrm{AD}$ o sujeito discursivo é uma posição descentrada de si e determinada por fatores de ordem sócio-histórico-cultural, nos Estudos Culturais, de igual modo, percebe-se a dispersão e a fragmentação inerentes ao sujeito social e defende-se a relação de interdependência entre as

23 Foucault (1979), quando trata dos "efeitos de verdade", entende a verdade como a regulamentação de um poder, ressaltando que esse processo difere de cultura para cultura, apesar de que o elemento verdadeiro sempre atua a favor de privilégios ao sistema. 
instâncias identidade, sujeito e discurso. Hall (2006), ao tratar das identidades culturais no que ele chama de Modernidade Tardia, aponta para o fato de que todo processo identitário se constrói vinculado a uma rede de memórias que o ancora e o legitima; ou seja, as identidades só existem no interior das instituições sociais e estão ligadas à cultura e ao imaginário social, de onde elas retiram seus símbolos e suas representações como construções sociais. Isto se deve a que as identidades não são propriedades com as quais nascemos, mas são construídas e/ou transformadas continuamente em relação às representações sociais que nos rodeiam.

\section{O arquivo político-midiático das eleições presidenciais de 2002}

Em 2002 um fato histórico despontou no ‘arquivo’ políticomidiático do Brasil como um cenário repleto de significados: as eleições presidenciais. Para Foucault (1997a, p. 149), o arquivo é "o sistema que rege o acontecimento dos enunciados como acontecimentos regulares [...] é o que diferencia os discursos em sua existência múltipla e os especifica em sua duração própria”. As eleições presidenciais daquele ano configuraram um embate constante na esfera midiática, fomentando inquietações e materializando saberes e poderes justamente por seu caráter singular.

Nos quatro primeiros meses do ano eleitoral a midiatização da campanha presidencial de Lula destinou maior visibilidade à sua conquista do primeiro lugar absoluto nas pesquisas de opinião. 
Conhecido marcadamente no Brasil e no mundo como a força política de esquerda que possuía um seguro eleitorado entre as classes mais humildes, Lula teve votação expressiva em suas três disputas pela presidência, mas não conseguiu uma vitória nos pleitos, especialmente, porque tinha dificuldade em conquistar os empresários e a elite do país, entre outros motivos, pelo viés socialista que apregoava.

Em2002, a queda dessa rejeiçãogarantiu automaticamente um crescimento maior nas intenções de voto a cada evento político do qual Lula participasse, como entrevistas, comícios e participação em debates. Essa oscilação ganhou contornos distintos em cada uma das revistas que compõem nosso arquivo. Para Foucault (1997a), não se pode descrever exaustivamente o arquivo de uma sociedade, de uma cultura, de uma civilização ou mesmo de uma época. Com base nessa concepção, o nosso mergulho na discursividade desse universo interroga a historicidade dos acontecimentos pela análise de alguns dos enunciados veiculados em duas reportagens de capa dos semanários que compõem nosso arquivo.

Foucault (1997a) procura delimitar o campo de utilização do vocábulo "enunciado", relacionando-o, pelo método arqueológico, ao conceito de língua, consciente de ela ser condição necessária para a produção de quaisquer enunciados. A concepção foucaultiana de enunciado não diz respeito à sua materialidade, nem à sua singularidade linguística, mas sim, à sua função, e é a partir daí que ela deve ser compreendida. Por isso, o que constitui um enunciado é o que Foucault chama de "função enunciativa", que diz respeito à produção desse enunciado por um sujeito que fala de um lugar institucional e "é determinado por regras sócio-históricas que definem e 
possibilitam que ele seja enunciado". (GREGOLIN, 2004, p. 26).

De acordo com Sargentini (2006), operar com a noção foucaultiana de arquivo significa estabelecer uma análise pautada em um conjunto de enunciados efetivamente produzidos. $\mathrm{Na}$ construção deste dispositivo de análise, o nosso primeiro gesto de interpretação consiste na delimitação de algumas operações interpretativas para a massa de dados inerentes ao nosso arquivo, que era formado inicialmente por 154 edições dos semanários de generalidades Época, IstoÉ e Veja. Em 2002 Lula figurou sozinho como reportagem de capa em doze edições desse montante, seis delas publicadas no período que vai do lançamento de sua candidatura até a última edição antes do pleito.

Assim, ao invés de tratar o tema de forma exaustiva, optamos por delimitar o objeto discursivo contemplando a "regularidade" das práticas discursivas em estudo. Em Foucault (1997a), a discussão do conceito de Formação Discursiva (FD) passa por uma sequência de formulação baseada em análises de princípios organizados em "sistemas de dispersão". Assim, a regularidade discursiva seria fruto do trabalho que o analista desenvolve ao organizar esses acontecimentos discursivos, buscando o que é regular na dispersão das relações linguísticas ou imagéticas dos enunciados. Neste sentido, em nosso dispositivo analítico, o conjunto de enunciados, imagens e/ ou discursos que aparece com frequência na manutenção de relações e/ou efeitos de sentido é entendido como regular, e a historicidade dos enunciados organizados em FDs serve de orientação para as análises que recortam o nosso arquivo. 
Nos três semanários impressos que analisamos, o cerne das reportagens geralmente se constitui em torno de temas do cotidiano brasileiro e de assuntos internacionais ligados à economia, à cultura e à política. Como revistas de generalidades, falam também de ecologia, artes, religião e tecnologia. $\mathrm{Na}$ cobertura das eleições, cada uma dessas mídias impressas teve uma postura própria, mas alguns dados são regulares no agendamento e no enquadramento da campanha de Lula. No caso específico que nos propomos a discutir, a regularidade está na discursivização de duas identidades colocadas como contraditórias na trajetória política do candidato do PT.

Segundo Navarro (2010, p. 82), “o jornalismo impresso pode ser caracterizado como uma empresa na qual os funcionários seguem uma rotina de trabalho determinada pela pauta editorial". Por sua formatação, a mídia impressa não consegue fazer coincidirem o tempo dos fatos e o da escritura, mas conta com uma infinidade de formas textuais a serviço de seus objetivos: o editorial, a crônica, a reportagem, a entrevista, o artigo de análise, a tribuna, etc. Apesar dessa hibridez, Charaudeau (2006, p. 234) ressalta que "é necessário que um texto escrito seja identificável como um tipo que se prenda mais particularmente a uma situação de enunciação". No caso específico de nosso corpus de análise, grande parte dos textos se presta a veicular informação através de reportagens de caráter noticioso. Para tanto, na maioria dos casos as matérias recorrem a procedimentos distintos e atestadores de veracidade e de fidelidade às cenas e aos fatos informados em suas edições. Assim, a desestabilização dos efeitos de verdade estabelecidos e o entendimento de como os veículos midiáticos intervêm na constituição dos sujeitos e na sua 
produção identitária se legitimam como um campo fecundo para o analista de discurso político-midiático.

\section{O "Sapo Barbudo" e o "Lulinha Paz e Amor"}

A maior regularidade que caracteriza a prática discursiva midiática das reportagens analisadas gira em torno da imagem/ postura do candidato do PT. Com o aumento da popularidade de Lula, a mídia deu início à produção de inúmeros questionamentos ao histórico político-ideológico do petista. A imagem que se constrói desse movimento midiático de denúncia contribui para a visualização de uma identidade incoerente de um candidato que mantinha duas posturas tidas como contraditórias e instáveis.

Nessa direção, nosso estudo identificou que, na maioria dos textos jornalísticos, o acionamento dos 'já-ditos' acerca da imagem e da postura que permearam a campanha de Lula nas eleições de 1989, 1994 e 1998 ocorre simultaneamente com uma alusão ao futuro político do petista. O estabelecimento de uma relação temporal que comparava o passado de derrotas com o presente de grande aceitação pelos eleitores do Brasil e de uma análise de como essa aceitação poderia repercutir nos rumos políticos do país se materializa, nesse movimento, primeiramente, na recuperação de uma identidade de socialista radical de Lula - o "Sapo Barbudo", e, depois, na publicização de uma segunda identidade, esta mais contemporânea - o "Lulinha Paz e Amor".

Assim, a emergência de uma imagem negativa do candidato é criada pela recuperação do seu passado político. Desde a 
fundação do P'T, Lula vinha representando a mais forte oposição ao governo e ao regime socioeconômico adotado pelo Brasil. Sua imagem pública era caracterizada como a de um candidato radical e comunista que não possuía experiência administrativa nem formação universitária. Por essa razão, na cobertura da campanha política do petista, foi regular, em nosso objeto de pesquisa, a publicação de depoimentos de consultores e economistas quanto às expectativas para um eventual futuro governo do PT, numa apresentação - pautada num discurso de autoridade sobre eventuais dificuldades de a esquerda compreender a lógica capitalista da economia brasileira, especialmente a esquerda, cujo nome forte em 2002 era Lula. Esse questionamento ainda mais regular apareceu, principalmente, pela publicação, na mesma página, de quadros, tabelas e frases do candidato que manifestam duas convicções que divergem de um período para o outro na sua história política.

A edição da revista IstoÉ de 14/08/2002 trouxe como reportagem-capa a figura de Luiz Inácio Lula da Silva. A materialidade discursiva da capa e da reportagem em si materializa, por estratégias linguísticas e imagéticas, a fragmentação identitária do petista. O enunciado-título dessa matéria já se configura numa esfera que caracteriza um estatuto discursivo repleto de sentidos. Em "Lula não assusta mais", o sujeito Lula é escrito em caixa alta, em tamanho maior, com letras vermelhas. Centralizado, o restante da oração segue abaixo do nome do candidato, também em caixa alta, mas em letras de cor preta. Além das representações históricas que esse jogo de cores aciona na memória discursiva do leitor, uma sombra branca que permeia o fundo do predicado dessa expressão tem na palavra "não" sua forma mais marcada, de maneira a ressaltar essa negação, iluminando seu panorama de fundo. 
No bojo dessa negação de que o candidato do PT pudesse assustar, em 2002, os interesses das grandes mentes políticoeconômicas do País, o vocábulo "mais" - que, no contexto, equivale ao advérbio temporal "agora" - recupera discursivamente o período anterior ao eleitoral, no qual o petista assustava o eleitorado brasileiro. A própria acepção do verbo "assustar", no título representado, conjugada à estrutura e à especificidade desse enunciado, é emblemática na emergência de um sentido cristalizado e de valor negativo sobre o radicalismo do candidato que disputara sua primeira eleição presidencial em 1989, por exemplo.

Ainda na capa, um enunciado introdutório complementa, em letras brancas, a historicidade inscrita no título: "Com a proposta de um capitalismo humanizado o candidato petista ganha elogios da imprensa conservadora estrangeira, é aprovado no debate da Rede Bandeirantes e é aplaudido na Fiesp e na Bovespa, onde 'antes' era um sapo difícil de engolir". Ao observar o discurso veiculado pela revista, vê-se uma argumentação estratégica que usa como tese a ideia de que somente o Lula de agora (período pré-eleitoral) conseguiu conquistar até os eleitores mais conservadores e defensores da hegemonia e do sucesso do sistema capitalista dentro e fora do país.

Como se vê, em oposição à representação "Sapo Barbudo", tanto na narrativa visual quanto na verbal, o próprio movimento combativo da imprensa procurou, por outro lado, caracterizar uma segunda (e conflitante aos olhos midiáticos) identidade do petista, o "Lulinha Paz e Amor". O enunciado em questão constrói duas posições distintas a serem ocupadas pelo sujeito político pós-moderno Lula, denunciando um candidato que se descaracterizava de seu lugar de origem para figurar com a identidade de um líder educado, gentil (dócil) 
e defensor de uma economia capitalista - atrativo imediato para o empresariado que ele precisava conquistar em termos de eleitorado. Dessa forma, a fragmentação da identidade de Lula se dá na e pela prática discursiva da mídia analisada. Segundo Bauman (1997), na sociedade do espetáculo midiático tudo deve ser efêmero, por isso na Pós-Modernidade há um processo de descentralização identitária através do qual identidades outrora fixas deixam de ser singulares para se tornarem multiplamente construídas ao longo de discursos, práticas e posições.

A presentificação dessa aceitabilidade de um "Lulinha Paz e Amor", inscrita nos verbos e perífrases verbais utilizados nas três primeiras orações desse enunciado: "ganha", "é aprovado", "é aplaudido", mantém comutação com o radicalismo e a instabilidade do passado político desse sujeito - passado que é marcado linguisticamente na quarta oração desse enunciado pelo uso do pretérito imperfeito do verbo 'ser' - "era" e pelo uso do advérbio temporal - igualmente pretérito - o 'antes', na metáfora: “onde antes era sapo difícil de engolir".

O valor metafórico da expressão/designação "Sapo Barbudo" também reclama o acionamento de um já-dito que alude ao passado político do petista. Segundo Markun (2004), em 26 de novembro de 1989 o candidato Leonel Brizola, em discurso aos militantes do PDT, após a derrota do partido no primeiro turno, declarou apoio a Lula, numa ironia que rapidamente se transformou numa perífrase associada ao candidato do PT: “Cá para nós: um político de antigamente, o senador Pinheiro Machado dizia que a política era a arte de engolir sapos. Não seria fascinante fazer esta elite engolir o Lula, esse Sapo Barbudo?" (MARKUN, 2004, p. 229). 
A edição da revista Veja de 22/05/2002, por sua vez, também trouxe como reportagem-capa o candidato do P'T. No fundo preto e quadriculado de um grande gráfico são comparados, em linha vermelha, o crescimento nas intenções de voto do petista, e em linha azul, o aumento do "Risco Brasil" na economia nacional. No canto inferior direito da capa, a cabeça de Lula voltada para cima (para os gráficos), com aparência descuidada e expressão facial preocupada, faz paralelo ao enunciado-título que, centralizado no canto inferior esquerdo e escrito em caixa alta e com letras brancas, mantém interdiscursividade com o título da revista IstoÉ analisada, "Por que Lula assusta o mercado", sobretudo pela escolha lexical do verbo "assustar" e por fazer menção à rejeição do candidato pelo empresariado.

No interior da reportagem é mobilizada a mesma visão sobre o acontecimento da campanha de Lula: o crescimento nas pesquisas, a preocupação do mercado, o relacionamento do petista com a elite do país, além das suas propostas de governo, tal qual no outro semanário analisado. Voltamos agora nossa atenção para a matéria "A vida começa aos 40\%". Nesse texto as jornalistas Sandra Brasil e Thaís Oyama retratam as mudanças físicas sofridas pelo candidato do PT e a mudança no modelo de autodivulgação escolhido pelo Partido dos Trabalhadores:

Sereníssimo e distinto em seus ternos bem cortados, o Lula de hoje mais parece o primo rico do ex-metalúrgico que, até a campanha de 1998, com cabelo crescido e barba espetada, brandia o microfone com ira sagrada nos discursos que fazia [...] Lula usava camisetas apertadas. Nem passava por sua cabeça aparecer com um paletó de grife, gravata italiana e camisas feitas sob encomenda. O candidato petista, o mundo inteiro notou, está caprichosamente vestido e penteado. Boa parte dessa transformação, como se sabe, se deve a Duda Mendonça”. [...] Mas, se Duda foi o principal responsável pela transmutação de Lula, a maior mudança partiu dele próprio: pela primeira vez em quatro 

campanha. (BRASIL; OYAMA, s/d., p. 48-49).

Nesse fragmento de texto, a análise dessas discursividades mostra as principais mudanças na imagem/postura do candidato do PT. Somada às informações da matéria e à fotografia de tamanho significativo, na qual Duda Mendonça, acompanhado por vários parceiros políticos, aparece coordenando uma das propagandas políticas de Lula em frente ao Planalto, outra construção discursivo-imagética se destina igualmente a apresentar elementos verbais cujos sentidos possibilitam fazer o reconhecimento das causas do avanço petista nas pesquisas, e o faz pelo acionamento discursivo da analogia.

Além de todo o conjunto imagem-postura retratado, essa edição da revista também destacou o novo modelo de autodivulgação escolhido pelo PT. Nas eleições anteriores Lula era divulgado, em seus megacomícios para trabalhadores, em tons sempre agressivos: voz exaltada, expressão séria e lutadora. Em 2002 Lula apresentou-se numa propaganda política diversificada e de caráter documentário, com trechos de sua vida pessoal, poses para revistas e um sorriso no rosto como sua identidade/marca, comprovando que "um corpo disciplinado é a base do gesto eficiente" (Foucault, 1997b). Com isto, uma vez apontado como o possível vencedor nas urnas pelas pesquisas, Lula mostrou ao Brasil e ao mundo que a matéria-prima de sua grande aceitação consistia no poder disciplinar de seu marqueteiro, que soube produzir um gesto eficiente à sua posição-sujeito político pósmoderno: o "Lulinha Paz e Amor".

$\mathrm{Na}$ Pós-Modernidade os veículos de comunicação invadiram a vida pública e privada de diversas maneiras e com várias materialidades, razão pela qual Hall (2006) defende que 
as identidades sejam compreendidas no interior de práticas discursivas específicas. Além disso, a mídia tende a construir identidades pormeiode estereótipos materializados em enunciados verbais, a fim de fixar, manter e estabilizar essas identidades em detrimento de outras. A identidade "Lulinha Paz e Amor" se configurou, no interior de seu acontecimento na campanha de Lula em 2002, como a fórmula ideal para o momento histórico das eleições. A própria imprensa, que acompanhou e divulgou a transformação por que passou o principal representante do PT nas eleições daquele ano, reconheceu que o novo Lula usava um procedimento necessário a uma grande aceitação política, mas no período discursivizou enfaticamente essa nova postura como passageira, como descaracterização de sua identidade de líder sindical e representante das causas populares.

\section{A mídia e a construção identitária do sujeito político da Pós-Modernidade.}

A partir da discursivização das identidades de Lula pela imprensa, foi possível compreender a fragmentação identitária desse sujeito político; mas é também relevante descrever como essa construção se realiza por intermédio das mídias. Com esse propósito vislumbramos, histórica e sucintamente, sobretudo com as contribuições de Foucault (1997), o surgimento dessa prática/política de contenção gesto-corporal como fruto de uma organização social pós-moderna.

Preocupado com as transformações das práticas penais da Modernidade, Foucault (1997b) descreveu a construção da 
ideia de prisão a partir de uma crítica ao perfil político de uma sociedade que se moldava pela normatização e pela docilização dos indivíduos tidos como delinquentes. Sua investigação pairou, nessa direção, sobre os processos de condenação que existiam na sociedade ocidental até o século XX. Nos primórdios dessa civilização descrita, o processo de condenação de criminosos era realizado por meio de suplícios (condenação em praça pública). Com a ideia "das mil mortes", o indivíduo criminoso deveria morrer aos poucos, sofrendo o espetáculo de sua morte também como espectador; mas com o tempo a insatisfação popular provocou uma brusca mudança de paradigma no processo judiciário francês e fez com que o espetáculo das mortes fosse substituído por outros processos de condenação. Pelo enclausuramento, o corpo não era mais tocado, mas passava por uma política de reeducação, justificada pelo discurso de que esse sujeito-corpo tinha de ser recuperado para ser reintegrado à sociedade como um corpo dócil e útil.

Depois dos suplícios, a prisão não era só um novo mecanismo punitivo daquela "Sociedade da disciplina", mas um dispositivo de controle sobre o corpo dos condenados. Um processo de semelhante controle nos convida a vislumbrar o surgimento de uma pedagogia do gesto na esfera política. A mesma preocupação com o uso do corpo na política de Lula em 2002 era um comportamento fundamental, enquanto na antiga sociedade monárquica francesa ${ }^{24}$ servia como base para a sedução inerente ao discurso político do Antigo Regime. Na história das relações políticas desse período, tal como na contemporaneidade pós-moderna, o homem público deveria ser dotado de um poder sobre o próprio corpo, um autogoverno, já que apenas essa

24 Em Vigarello (2008), somos convidados a conhecer essa preocupação em períodos ainda mais anteriores ao retratado aqui, sobretudo na política da França ou da Inglaterra. 
moderação garantiria o fundamento para o governo dos outros corpos.

O cerne desse controle, o uso da etiqueta, atuava como ferramenta de dominação dos corpos e das opiniões durante o Absolutismo francês. No Brasil presidencialista de 2002, a organização dessa política de controle gestual e comportamental teve contornos distintos na campanha de Lula, mas remete, no seio de suas configurações, à organização monárquica antiga. Esse ritual solene começou muito antes da campanha, na preparação de uma esfera discursivo-imagética através da qual o candidato do PT pôde demonstrar, na verbalidade das palavras e na contenção dos gestos, o conhecimento das causas populares, sociais e econômicas num verdadeiro limiar entre o espetáculo de sua figura pública e o domínio do seu grau de autoexposição.

O panorama histórico do uso do corpo na política, bastante explorado em autores como Haroche (1998) e Courtine (2003), convida-nos a refletir sobre como a ótica baseada na vigilância e no controle dos corpos, que era aplicada pelo sistema monárquico do Antigo Regime, reside, na contemporaneidade -entre tantas outras esferas -, no sistema político do país, devido à configuração da política de nossos tempos, que é completamente ambientada pela mídia.

Ao contrário de uma política do silêncio, como a pregada na Monarquia, Lula passou um longo período, antes das eleições, no arquitetar de discursos bem convincentes e impactantes. Apesar disso, tal como no regime monárquico, suas palavras tiveram de ser marcadas pela sobriedade no tom, nos conteúdos e nas propostas políticas divulgadas, para que o candidato pudesse ganhar a admiração dos súditos/eleitores e impedir que toda a pompa real, construída em meses de 
campanha, o destronasse mais uma vez, em sua quarta disputa pela presidência.

Em 2002 essa mudança nouso do corpo do candidato petista foi amplamente discutida pela mídia como inédita e contraditória, mas a preocupação com a contenção corporal na campanha de Lula tem raízes que remontam ao modelo monárquico em vários aspectos. Nela, a vestimenta solene (o terno), o trato com a higiene (a barba, o penteado, a maquiagem), tudo caminha para a exibição de um corpo saudável, aparente, seguro e confiável. Nos gestos, o cenário é ainda mais peculiar. Nas aparições públicas, midiatizadas ou não, o candidato procurou se fazer ver, tal como os monarcas franceses, acenando com recato para as fotografias do olhar vigilante da mídia mais que se aproximando do calor do povo.

Na verdade, em 2001, a campanha petista já dava seus primeiros passos e a direção do P'T já manifestava o desejo de que Lula participasse de sua quarta disputa pela presidência, mas sabia que a condição básica de sua candidatura seria produzir uma campanha a partir da última exigência do próprio candidato: contar com o apoio do marqueteiro Duda Mendonça. Em todos os trabalhos que produziu, o publicitário procurou manter os valores dessa candidatura, acentuando as qualidades do próprio Lula: “- Ninguém sabia quem era o Lula, ele era uma barba política. Resolvi mostrar que ele era um homem casado, que tem família, netos, que é um bom pai." (Duda Mendonça in MARKUN, 2004, p. 331).

No trecho em destaque o marqueteiro petista retrata como se dera a criação de uma esfera particular e familiar de Lula, voltada à criação de uma imagem segura e confiável para sua divulgação durante a campanha. A política midiatizada requer um 
corpo diferente, que se enquadre na tela e faça vislumbrar nessa aparição a essência de um rosto, de uma personalidade tranquila e alegre. Na campanha petista, a preocupação com esse caráter particular do candidato também se fez notória na proposta de marketing político empreendida por Duda Mendonça, que mudou o modo de se vestir do candidato para a adoção de um estilo que o permitisse figurar, de um lado, como líder e representante popular e, de outro, como líder e representante da elite brasileira, conforme fala de Duda Mendonça apresentada na sequência:

- Eu não mudei o Lula. Meu esforço foi o de mostrar que o Lula poderia ser ele mesmo. O Lula que aparecia nas campanhas - mal humorado, cara de bravo, rancoroso - era de mentira. Se eu tive algum mérito nessa campanha foi convencê-lo a ir para a televisão como ele é: chorar, rir, piscar o olho, ser sedutor, brincalhão. (MARKUN, 2004, p. 332).

Esse aspecto histórico da vida política de Lula que Markun ${ }^{25}$ (2004) nos apresenta explicita movimentos que mostram um trabalho de adaptação política que é tecido gradualmente no P'T e culmina com a impressão de uma versão final na campanha de 2002. No desenhar desse novo perfil político vemos também a mídia aparecendo em nova roupagem: como porta-vozes de verdades desconhecidas pelo povo, os veículos de comunicação dedicam-se cada vez mais a tornar visíveis conteúdos políticos existentes nas profundezas implícitas de cada campanha. Uma análise desse novo papel da mídia, não contemplada neste artigo, já tem sido realizada em nossos trabalhos, como em Romualdo

25 Nossa menção às proposições de Markun (2004) não implica que tenhamos entendido os fatos por ele contados como o retrato fiel de uma realidade vivida por Lula. Nossa escolha por abordar esta literatura se justifica pela completude com que ela aborda muito do percurso de Luiz Inácio desde antes de o petista cogitar sua candidatura à presidência. 
e Santos (2010), mas ainda constitui, sem dúvida, um relevante tema a ser tratado em pesquisas da área.

\section{Considerações finais}

As transformações pelas quais passou a sociedade nos últimos anos deram abertura para a descentralização dos sujeitos considerados unos e a fragmentação das identidades. Essa mudança de paradigma tem fomentado estudos que buscam compreender a chamada crise de identidade social. Com igual preocupação, empreendemos, neste artigo, um mergulho singelo na compreensão de como algumas representações discursivizadas pela mídia contribuem para a produção de um efeito de contradição inerente à fragmentação identitária do sujeito político Lula.

Como a identidade está atrelada à historicidade e à memória, acionamos o método arqueológico de Foucault (2007a) para emaranhar nossa leitura nos enunciados engendrados por duas mídias impressas escolhidas entre os semanários que compõem o arquivo de nosso objeto de estudo. Nesse caminho, vislumbramos como a passividade e a contenção da realeza do Antigo Regime, assim como a preocupação com um gesto moderado e um corpo saudável, são marcas essenciais também na política presidencialista brasileira, especialmente quando de suas figurações no veículo midiático. Como processos propagandísticos antigos e clássicos, tais preocupações com o uso do corpo e do gesto tiveram destaque, como apresentado neste artigo, na campanha eleitoral do candidato do PT durante as eleições presidenciais de 2002. 
Ao passo desse empreendimento pela divulgação de uma imagem de Lula elaborada nos entornos dessa preocupação, a mídia brasileira questionou a campanha petista como uma possível descaracterização do candidato e do partido após três consecutivas derrotas em eleições anteriores; no entanto o processo de mudança que permeou a campanha presidencial do PT foi muito mais um movimento de adaptação à necessidade de midiatização da política, essencial ao sujeito político da Pós-Modernidade do que algum tipo de descaracterização identitária. O motivo dsso é que, exigida pelo novo contexto sócio-histórico da política nacional, a preocupação com o uso do corpo e do gesto na produção da campanha de Lula culminou com as eleições de 2002, mas como uma adaptação tardia, se comparada à política de muitos outros partidos no Brasil e no mundo, que já se adaptava às "lições" deixadas por tempos remotos.

Os efeitos de sentido regulares produzidos pela mídia para a construção identitária do candidato se baseiam em uma descaracterização da formação discursiva de esquerda que marcava a identidade de Lula como representante das classes populares - o "Sapo Barbudo", favorecendo o surgimento de uma nova identidade: o "Lulinha Paz e Amor" - um candidato que defendia agora ideais de cunho capitalista, a fim de conquistar uma vitória no pleito em sua quarta disputa pela presidência do país. O convívio dessas duas identidades, as quais foram colocadas como contraditórias nas práticas discursivas das revistas analisadas, contou com recursos diversos destinados, de um lado, à criação de um efeito de verdade para as informações narrativizadas pelos veículos de comunicação, e de outro, à desqualificação da imagem do candidato do PT meses antes das eleições em que ele era o candidato mais bem cotado nas pesquisas de opinião. 
Mais do que a veracidade desse processo de fragmentação identitária contraditória atribuído ao candidato do PT em 2002 pelo discurso midiático, é necessária a percepção de um novo sujeito político pós-moderno e das especificidades de sua identidade. Entender esses movimentos políticos é, como se nota, um convite a um envolvimento maior com a história já escrita de nossa política e com os próximos episódios. $\mathrm{Na}$ materialidade dos corpos e dos gestos, a produção de sentidos marca a vida em sua plenitude também na política de nosso tempo: navegar por essa discursividade é, pois, mais que um gesto de análise, uma compreensão do ontem, do hoje e do amanhã.

\section{Referências}

BAUMAN, Z. Modernidade líquida. Rio de Janeiro: Jorge Zahar, 1998.

CHARUDEAU, P. Discurso das mídias. São Paulo: Contexto, 2006.

COURTINE, J. J. Discurso e mídia: a cultura do espetáculo. In.:

GREGOLIN, M. do R. V.(org.). Discurso e mídia: a cultura do espetáculo. São Carlos: Claraluz, 2003. p. 21-34. (Coleção Olhares Oblíquos). - Metamorfoses do Discurso Político: derivas da fala pública. São Carlos: Claraluz, 2006.

FOUCAULT, M. Microfísica do poder. Organização e tradução de Roberto Machado. Rio de Janeiro: Edições Graal, 1979.

- A arqueologia do saber. Tradução. Luiz Felipe Baeta Neves. 5. ed. Rio de Janeiro: Forense Universitária, 1997a.

.Vigiar e Punir. 16. ed. Rio de janeiro: Editora Vozes Ltda, 1997b. 
GREGOLIN, M. R. F. V. O enunciado e o arquivo: Foucault (entre)vistas. In. SARGENTINI, V; NAVARRO-BARBOSA, P. (Org). Foucault e os dominios da linguagem: discurso, poder, subjetividade. São Carlos: Claraluz, 2004.

HALL, S. A identidade cultural na pós-modernidade. 11. ed. Trad. Tomaz Tadeu da Silva, Guacira Lopes Louro. Rio de Janeiro: DP\&A, 2006.

HAROCHE, C. Da Palavra ao Gesto. Tradução Ana Montoia e Jacy Seixas. São Paulo: Papirus, 1998.

MARKUN, P. O sapo e o príncipe: personagens fatos e fábulas do Brasil contemporâneo. Rio de janeiro: Objetiva, 2004.

NAVARRO, P. Uma definição da ordem discursiva midiática. In.:

MILANEZ, N.; GASPAR, N. (orgs.). A (des)ordem do discurso. São Paulo: Contexto, 2010. p.79-93.

REVISTA ISTOÉ. São Paulo: TRÊS, no 1715, 14 de ago. 2002.

REVISTA VEJA. São Paulo: ABRIL, Ano 35, nº 20, 22 de mai. 2002.

SANTOS, E. M. O espetáculo político e a docilização do corpo na campanba eleitoral de Lula em 2002. 2009. 167 f. Dissertação (Mestrado em Letras) - Programa de Pós-graduação em Letras, Universidade Estadual de Maringá, Maringá, 2009.

ROMUALDO, E. C.; SANTOS, E. M. Midiatização e espetacularização: os entornos da mídia na campanha eleitoral de Lula em 2002. In: POSSENTI, S.; PASSETTI, M. C. C. (Orgs.). Estudos do texto e do discurso: mídia e política. Maringá: Eduem, 2010. p.123-148.

SARGENTINI, V. M. O. Arquivo e acontecimento: a construção do corpus discursivo. In. NAVARRO, P. (org). Estudos do texto e do discurso: mapeando conceitos e métodos. São Carlos: Editora Claraluz, 2006. p. 35-44. 


\section{MISOGINIA E ANTICOMUNISMO NA XILOGRAVURA DE CORDEL}

Cláudia Rejanne Pinheiro Grangeiro ${ }^{26}$

\section{Introdução}

As reflexões sobre discurso, imagem, sujeito e identidade que se seguem são parte constitutiva da nossa tese de doutoramento intitulada Discurso político no folheto de cordel: $A$ "Besta-fera", o Padre Cícero e o Juazeiro. Como referencial teóricometodológico tomamos a Arqueologia de Michel Foucault (1999, 1997), teórico cujas preocupações apontavam para a relação entre os poderes/saberes responsáveis, principalmente, pela produção das subjetividades contemporâneas. Também fazem parte das nossas referências os postulados do "grupo em torno de Michel Pêcheux", que considera as identidades sociais não como elementos estanques dados a priori, mas antes de tudo como "processos identitários" constituídos no e pelos discursos, bem como as reflexões de J.J Courtine (2006) sobre o papel da imagem nas sociedades contemporâneas, a qual. Segundo o autor, aponta a necessidade de um dispositivo de análise da "ordem do olhar". Em vista desta perspectiva, o trabalho consta

26 Professora da Universidade Regional de Cariri (URCA). 
de uma análise dos mecanismos de constituição da subjetividade feminina no âmbito do discurso político. Para tanto, procedemos à análise da xilogravura da capa do polêmico folheto "Enganame que eu gosto 2", de Abraão Batista, que circulou em Juazeiro do Norte - CE por ocasião das eleições para prefeito daquela cidade em 2000, após a interdição judicial do primeiro folheto: "Engana-me que eu gosto".

\title{
Língua, discurso e imagem
}

\author{
Quanto mais longe vou \\ Mais estou voltando para casa \\ (Cora Coralina)
}

A chamada Análise do Discurso francesa (AD) preconizada pelo grupo em torno de Michel Pêcheux, a qual nasceu articulando, em regiões fronteiriças, uma leitura althusseriana do marxismo, uma leitura lacaniana de Freud e uma leitura pecheutiana de Saussure e da Linguística, por não separar teoria e intervenção política, apresentava uma teoria do discurso (sustentada ideologicamente) e um dispositivo experimental (análise automática). Assim, em princípio, o corpus a ser analisado consistia num conjunto determinado de textos ou sequências discursivas retirados mediante o processo de extração ou isolamento de um campo discursivo de referência. O objeto privilegiado da $\mathrm{AD}$ era o discurso político-partidário e o seu objetivo era encontrar a ideologia dessas formações discursivas. Para isso recortavam-se corpora verbais escritos ou transcritos e aplicava-se o método da "análise automática" para depreender as 
sequências parafrásticas que constituíam os sentidos. Mais tarde, tanto a teoria quanto o método e os objetos da $\mathrm{AD}$ sofreram consideráveis transformações. Com a ascensão da mídia impressa ilustrada, da tevê e da internet, os textos contemporâneos já não se apresentam apenas em linguagem verbal, mas em sistemas híbridos, sincréticos, conjugando diversas materialidades inscritas, ainda, em gêneros de discurso diversos. Tais transformações colocam desafios para a Análise do Discurso e a necessidade de aproximações teóricas com a Semiologia. A partir de tais questões, a própria concepção de língua fundadora da Linguística como "conjunto de signos verbais" pode e deve ser rediscutida. Dessa forma, embora no momento não nos aprofundemos nesse aspecto, julgamos de alta pertinência a discussão proposta por J.J Courtine (2006), na direção de uma semiologia histórica que articule a relação necessária entre língua (numa perspectiva mais ampla que a "langue" saussuriana) e uma teoria que dê conta da imagem como materialidade contemporânea fundamental, o que nos direciona para a leitura da "ordem do olhar" e da história não como exterioridades, mas como constitutivas dos discursos semiotizados nas mais diversas materialidades.

Assim, quanto mais longe vai a Análise do Discurso em seus desdobramentos contemporâneos, mais se tem sentido a necessidade de um retorno (no sentido nietzscheano) aos fundamentos da Linguística como parte de uma ciência geral dos signos. ${ }^{27}$ Desta forma, quando Courtine (1999, p. 15) diz que "para se trabalhar com a categoria de Discurso é necessário ser linguista e esquecer que o é ao mesmo tempo", pode ser que devamos considerar atentamente essa possibilidade no sentido

27 No Brasil, há diversos grupos e pesquisadores trabalhando neste sentido. Ver os ANAIS do I e II CIAD - Colóquio Internacional de Análise do Discurso. UFSCAR. São Carlos, 2006 e 2009. Disponível em < http://www.ppgl.ufscar.br/ciad>. 
empregado pelo autor, ou seja, "esquecer" que a língua já foi estudada, desconsiderando os fatores sócio-históricos que a constituem e a tornam possível, e começar a repensar também os hodiernos desafios da ciência da língua(gem), uma das bases fundamentais da Análise do Discurso que praticamos.

\title{
Ecos de memória, vozes de sujeitos
}

\author{
Quantas vezes a memória \\ Para fingir que inda é gente, \\ Nos conta uma grande história \\ Em que ninguém está presente
}

(Fernando Pessoa)

Quando se fala de sujeito no interior da Análise do Discurso em autores diferentes, não se está falando da mesma coisa. Em Foucault, o sujeito é uma posição neutra, vazia, que pode ser ocupada, em distintos momentos, por diversos indivíduos, além de ser tecido - assim como o discurso - na teia de dizeres intimamente relacionados com os poderes e os saberes, como também pelas técnicas de si (materializadas pelas práticas de confissão, pelo cuidado com o corpo, etc.). Para Foucault, o sujeito não existe a priori, nem na sua origem nem numa suposta essência imanentista, portanto não há nenhum tipo de essência identitária per se. A identidade do sujeito é uma construção histórica, temporal. O sujeito, para Foucault, é disperso, descontínuo, podendo adquirir diversas posições, inclusive a de autor: "somos seres de linguagem e não seres que possuem linguagem” (FOUCAULT, 2000, pp. 20/ 21). E ainda: "No curso da sua história, os homens jamais cessaram 
de se constituir, numa série infinita e múltipla de subjetividades diferentes, que jamais terão fim e que não nos colocam jamais diante de alguma coisa que seria o homem". (FOUCAULT, 2004 p. 236, grifos nossos).

Já em Michel Pêcheux o sujeito, embora clivado, cindido, atravessado constitutivamente por outras formações discursivas, ainda está ligado às ideologias. Para Pêcheux (1997), o sujeito que enuncia o faz de um lugar social, sócio-histórico, funcionando como porta-voz dos discursos, advindo daí a ilusão de univocidade do sujeito e das formações discursivas. ${ }^{28}$ Não obstante, essa univocidade é desfeita no momento em que se inicia o trabalho de desenredar os fios descontínuos e ininterruptos tecidos pelos discursos. Isso quer dizer que as formações discursivas não são homogêneas, ao contrário, elas são traspassadas e entrecortadas por saberes/dizeres produzidos em outras regiões cujos sentidos são deslocados, dialogam, parafraseiam-se, transformando-se, reelaborando-se, fazendo com que todos os trajetos de uma região a outra pareçam possíveis. Elas são recuperáveis por meio do interdiscurso, da memória discursiva - definida por Pêcheux (1999) como

28 Não nos vamos aprofundar neste debate por não ser objetivo deste trabalho. Por enquanto parece-nos suficiente admitir uma proximidade teórica entre estes dois autores quanto à ideia de discurso como prática social, bem como o anti-humanismo de ambos em conceber um sujeito "fora de si", ou seja, um sujeito descentrado, atravessado por outros dizeres e não como agenciador consciente do seu próprio discurso. A propósito dos "diálogos e duelos" epistemológicos entre os autores ver GREGOLIN, M. R.V. Foucault e Pêcheux na construção da análise do discurso: diálogos e duelos. São Carlos: Editora Claraluz, 2004 e GRANGEIRO, C.R.P. Foucault, Pêcheux e a formação discursiva In: BARONAS, R. L. (Org.) Análise do discurso: apontamentos para uma história da noção-conceito de formação discursiva. São Carlos, SP: Pedro e João Editores, 2007. 
Aquilo que, em face de um texto que surge como acontecimento a ler, vem restabelecer os 'implícitos' (quer dizer, mais tecnicamente, os pré-construídos, elementos citados e relatados, discursos-transversos, etc.), de que sua própria leitura necessita: a condição do legível em relação ao próprio legível. (PÊCHEUX, 1999, p. 54 - aspas do autor, grifos nossos).

Assim, todo dito é um 'já-dito’ em outro lugar que atua de forma decisiva no processo de memória/esquecimento, responsável pela ativação de determinadas representações culturalmente construídas, arquivadas na memória discursiva, cultural e sócio-histórica, e pela produção e interpretação dos efeitos de sentido contidos nos diversos enunciados.

Para Courtine (2006, p. 88), o discurso político é um lugar de memória e a memória é, ela própria, um poder. $\mathrm{O}$ autor toma de empréstimo um termo de Pièrre Nora, que assim define o lugar de memória:

O que nós chamamos de memória é, de fato, a constituição gigantesca e vertiginosa do estoque material daquilo que nos é impossível lembrar, repertório insondável daquilo que poderíamos ter necessidade de nos lembrar [...]. À medida que desaparece a memória tradicional, nós nos sentimos obrigados a acumular religiosamente vestígios, testemunhos, documentos, imagens, discursos, sinais visíveis do que foi, como se esse dossiê cada vez mais prolífero devesse se tornar prova em não se sabe que tribunal da história. (NORA, 1993: p. 15).

Não obstante, quando Courtine (1999a, p. 72) discute a questão da memória, ele o faz na perspectiva do que chama de 'memória discursiva'. Partindo do ponto de vista do enunciado como 'acontecimento discursivo', a memória discursiva é concebida, assim, como a articulação entre singularidade e repetição. Tudo que é dito é necessário que já tenha sido dito, e esse dizer jamais é repetido. É necessário que algo já tenha sido dito e esquecido, apagando-se certos sentidos para assim 
ressurgir e fazer outros sentidos. O que ouvimos, pois, são apenas ecos, fragmentos de coisas já ditas. Para Courtine (1981), "a memória concerne à existência histórica do enunciado, no seio de práticas discursivas (...), capaz de dar origem a atos novos, no sentido de que toda a produção discursiva acontece numa conjuntura dada e coloca em movimento formulações anteriores já enunciadas."

No tocante à análise dos aspectos concernentes à memória, no âmbito da leitura de imagens, J.J Courtine (2005, 2006) cunhou o conceito de 'intericonicidade', termo que, na esteira do princípio da interdiscursividade, é a relação que o elemento icônico mantém com outros anteriormente realizados, no sentido de ativar/recalcar dizeres já ditos, ou mais precisamente, já mostrados. Segundo o autor, "de la même façon qu'il y a des mots sur les mots, il y a des images sur les images". ${ }^{29}$ A imagem fala, portanto, também com outras imagens, ativando elementos da memória discursiva de quem vê cujos efeitos de sentidos são construídos nesse jogo de memória/ ocultamento. Para o autor,

Toda imagem tem um eco, ela se insere numa cultura visual, o que pressupõe, para o sujeito, uma memória visual. A princípio, poderíamos supor que essa imagem diz respeito apenas às imagens vistas. Mas essa relação intericônica pode se relacionar, também, com as imagens sugeridas, as imagens externas, mas também internas, as

29 « Da mesma forma que existem palavras sobre as palavras, existem imagens sobre as imagens ». (Tradução nossa). O autor ainda não publicou suas elaborações sobre este tema. Nossas citações são oriundas dos seus seminários na Sorbonne-Paris IV - Saint Jacques, de outubro de 2005 a fevereiro de 2006 e de uma conferência proferida na UFSCAR, em São Carlos (SP), em 26 de novembro de 2006, por ocasião do I Colóquio Internacional de Análise do Discurso - CIAD e de entrevista concedida a Milanez, em 2005, publicada em 2006. 
imagens de impressões visuais, imaginadas, pelos sujeitos. Imagens que nos reportam a outras imagens. O importante é que essa discussão sobre a imagem coloca o corpo no centro da análise. Portanto, a intericonicidade supõe a relação entre as imagens exteriores ao sujeito. Como quando uma imagem pode ser inscrita numa série de imagens, uma genealogia como uma série de formulações, segundo Foucault (Arqueologia do Saber). (COURTINE, 2005 apud MILANEZ, 2006, p. ??).

Assim, é considerando a imagem da xilogravura de cordel como um ícone, como um "acontecimento a ler", que a analisamos na perspectiva discursiva da intericonicidade, cujos sentidos são tecidos entre memória e atualidade. A memória, na perspectiva da Análise do Discurso, não é concebida no sentido psicológico, individual, mas presumida pelo enunciado enquanto inscrito na história a partir do qual, mobilizando toda uma rede de dizeres, ditos e não ditos, ditos e esquecidos, de imagens vistas e não vistas, o sujeito vai sendo discursivamente construído.

\section{Imagem xilográfica e cordel}

Embora a xilogravura seja reconhecida internacionalmente como arte plástica autônoma, sua origem está bastante ligada aos folhetos de cordel. Recebe o nome genérico de "Literatura de Cordel" uma extensa produção de folhetos impressos, difundidos principalmente no Nordeste Brasileiro desde o século XIX. A maioria dos pesquisadores, entre eles Diegues Jr. (1975) e Cascudo (1994), atribuem sua origem a folhetos portugueses que teriam sido trazidos para o Brasil no processo de colonização; mas vários pesquisadores 
contemporâneos discordam desta visão e atribuem a origem dos folhetos à poesia oral dos violeiros, emboladores e repentistas do Nordeste brasileiro. ${ }^{30}$

Os folhetos são pequenas brochuras geralmente impressas em papel-jornal tamanho $15 \mathrm{~cm}$ x $11 \mathrm{~cm}$ e escritas em versos rimados. Antes eram comercializados nas feiras e praças públicas, mas hodiernamente adquiriram outras materialidades, como a internet - o que denominamos, em outro trabalho, de "cibercordel" (GRANGEIRO, 2006) - e apresentam uma imensa variedade temática. No tocante às discussões em torno de sua origem e história, o fato é que essa forma de expressão está presente de forma tão profunda no Nordeste do Brasil que se transformou rapidamente num dos principais elementos da cultura desta região e adquiriu funções diversas em todos os campos da sociedade, como instrumento de alfabetização, meio jornalístico e fonte histórica. É utilizada também como mídia política, por ter bastante aceitação nas diversas camadas sociais, sobretudo nos setores populares. Segundo Chartier (1990, p. 23-24), no processo de constituição da interpretação em que se articulam autores, textos e leitores - o conteúdo (denominado pelo

30 Há um grupo de pesquisadores sobre Literatura de Cordel, entre os quais me incluo, autodenominado "Movimento pela Diferença Nômade", desenvolvendo pesquisas que vêm, paulatinamente, desconstruindo as concepções tradicionais do cânone dos estudos sobre cordel, as quais, em sua maioria, apontam esta prática cultural como oriunda de Portugal, como poesia escrita e feita por homens. O Movimento considera que tais parâmetros de estudo estão baseados, em sua maioria, em princípios eurocêntricos, grafocêntricos e androcêntricos. Para estes pesquisadores contemporâneos, o Cordel é o "produto tardio" (Ria Lemaire) de toda uma tradição da oralidade, além do cancioneiro universal, do universo da poesia oral do Nordeste brasileiro, com sua imensa gama de cantadores, emboladores, repentistas, poetas, declamadores, etc. De acordo com Santos (2009), ao se considerar o Cordel como parte dos processos da oralidade é que se torna possível a audição das vozes femininas nesse universo desde o século XIX, como autoras tanto de literatura de Cordel quanto de cantorias. 
autor de mise en texte) do material que se dá a ler não pode ser desvinculado da sua materialidade, do mise en livre/mise en Page; ou seja, a colocação dos tipos, o tipo de impressão, a hierarquização dos seus elementos, tudo isso oferece ao leitor determinados protocolos de leitura.

Em outras palavras, no processo de produção/recepção de determinado conteúdo de leitura, é importante levar em consideração também as materialidades que em determinados contextos são mais eficazes que outras. No caso do folheto de cordel, por exemplo, embora não pertença aos gêneros tradicionais em que se veiculam discursos políticos, verificase que esse tipo de "mídia" possui uma aceitação maior em Juazeiro do Norte pelos seus leitores potenciais, do que, por exemplo, panfletos ou outro gênero mais tradicionalmente "político", o que provavelmente não ocorreria em outra região do país.

Esse gênero híbrido traz as duas formas de expressão: a poesia e a xilogravura, principal forma de ilustração das capas dos folhetos. Os primeiros cordéis não traziam xilogravuras. As ilustrações eram feitas por meio de clichês, de zincogravura ou litogravura. Essa técnica surgiu depois do aparecimento dos folhetos.

A palavra xilogravura vem do grego xylon (madeira) e graphein (gravar), portanto significa 'gravura em madeira'. A imagem xilográfica é talhada em madeiras leves - como umburana, pinho, cedro, cajá e outras -, com tesoura de uma perna só, banda de gilete, quicé (faca de cortar fumo), formão ou canivete, ou, conforme afirma Lopes (1982), com "qualquer instrumento cortante, desde que tenha fio afiado suficiente para abrir os sulcos e deles tirar as crenças e tradições caboclas 
vestidas de anjos ou demônios, de gente ou bichos, de heróis e bandidos". Em seguida, o "taco" é embebido em tinta e transferido para o papel como uma espécie de carimbo. No Nordeste, os precursores dessa arte (Inocêncio da Costa Nick (Mestre Noza), Walderêdo Gonçalves, Antônio Relojoeiro e outros) - são da região do Cariri cearense.

A xilo em questão foi veiculada em Juazeiro do Norte CE como capa do folheto intitulado Engana-me que eu gosto 2, de Abraão Batista, em setembro de 2000, por ocasião das eleições municipais. O folheto é composto de dois volumes. ${ }^{31}$ Essa eleição foi um marco na história de Juazeiro, pelos elementos sóciohistóricos e do imaginário coletivo que mobilizou e pelo fato de que, pela primeira vez na história política desta cidade, uma mulher de esquerda, neófita em política, ameaçou a hegemonia dos grupos políticos tradicionais que se revezavam no poder havia quase 70 anos. Havia quatro coligações, no entanto a disputa eleitoral foi polarizada entre duas de matizes ideológicas à época diferenciadas: a frente encabeçada pelo PFL (Partido da Frente Liberal, hoje Democratas - DEM), com o candidato Carlos Alberto da Cruz, e a Frente de Esquerda PT/PSTU, encabeçada por Maria Íris Tavares. O cordel foi a resposta do autor a uma fala da candidata do P'T em que critica a administração do Centro de Cultura Mestre Noza, propondo transformá-lo numa cooperativa de artesãos.

Juazeiro do Norte é uma cidade de aproximadamente 250.000 mil habitantes, localizada no Vale do Cariri, Extremo Sul do Ceará, a $550 \mathrm{~km}$ de Fortaleza. É nacionalmente conhecida por causa das romarias a Nossa Senhora das Dores e ao Padre Cícero

31 A Análise do primeiro folheto será publicada na forma de artigo intitulado $\mathbf{O}$ sujeito político feminino nas trilhas de memória da xilogravura de cordel na próxima Revista da ABRALIN. 
Romão Batista, polêmico personagem histórico, considerado santo por uma grande parcela da população do Nordeste, principalmente por causa do chamado "fenômeno da hóstia": em 1889, no momento em que o padre oferecia a comunhão a uma jovem devota conhecida por Beata Maria de Araújo, esta não pôde deglutir a hóstia, pois esta se transformou em sangue. Antes desse fato, Padre Cícero declarara, no primeiro inquérito instituído pela Igreja Católica para apurar outros fenômenos ocorridos com Maria, que esta já havia, em outras ocasiões, apresentado os estigmas da crucificação de Cristo. Tal fenômeno gerou um choque entre a política de romanização da Igreja no século XIX na difusão do culto aos santos europeus e maior fundamento doutrinário entre os fiéis e o catolicismo popular prenhe de ladainhas, benditos, procissões e promessas aos santos populares (GRANGEIRO, 2002).

Desta forma, o Padre Cícero, mesmo nunca tendo sido reconhecido como santo pela Igreja Católica, é considerado como tal pela população do Nordeste, constituindo-se como mito fundador da cidade. Neste sentido, todo o conjunto de enunciados que se constituiu em torno da figura do Padre Cícero construiu a santidade do padre como um elemento "fundador de discursividade" (Foucault, 1999) na cidade. Desta forma, todas as regiões do dizer (o comércio, a mídia, a escola, o discurso político), para enunciar, para legitimar o seu próprio discurso, em Juazeiro, normalmente se baseiam na autoridade do Padre Cícero. 
Terceira parte : : Misoginia anticomunismo na xilogravura de cordel

Misoginia e anticomunismo num caldeirão de memórias

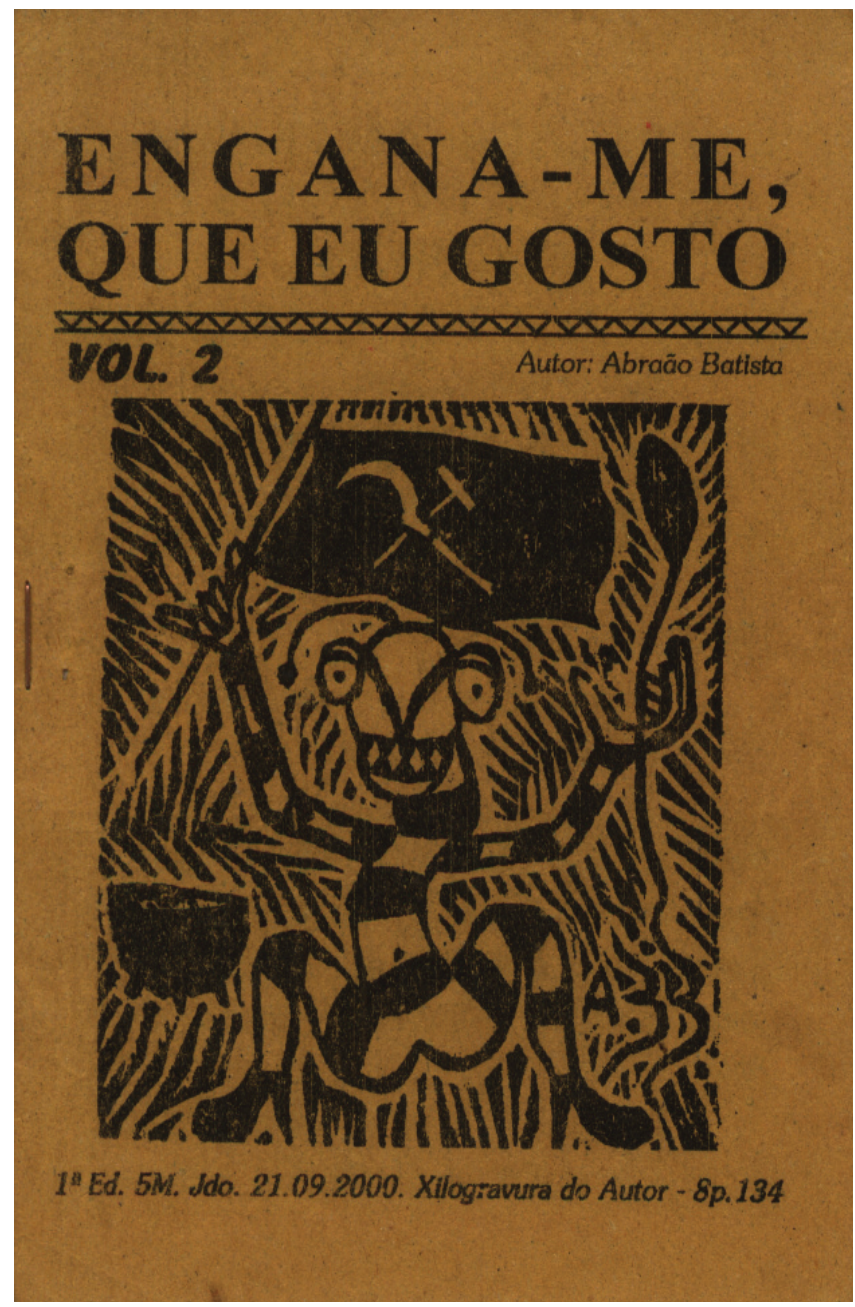

Figura 1 - Xilogravura Engana-me, que eu gosto. 
No processo de desqualificação do discurso da candidata do PT, a imagem xilográfica lançou mão de uma caricatura da imagem desta candidata. A caricatura (do italiano caricare carregar, no sentido de exagerar, aumentar algo em proporção) é um desenho que enfatiza e exagera as características de alguém de forma humorística, além de acentuar gestos e hábitos particulares a cada pessoa. A caricatura é herdeira do Expressionismo, movimento segundo o qual a arte expressaria os aspectos que a índole e a alma deixam na face da pessoa. A caricatura da xilo em questão cria um efeito de derrisão, procedimento comum no discurso político. De acordo com Bonnafous (2003, p. 35), "a derrisão é a associação do humor e da agressividade que a caracteriza e a distingue da pura injúria. [...]"; é, pois, uma forma de "desqualificar o outro por meio do ridículo" (BONNAFOUS, 2003, p. 37).

Podemos dividir a imagem em duas partes: rosto e corpo. $\mathrm{O}$ rosto faz sentido imediatamente. Nenhum outro espaço do corpo é mais apropriado para determinar a singularidade e sinalizálo como cerne do nexo social. Por ele a pessoa é reconhecida, identificada. Dessa forma o rosto da imagem, as antenas sobre a cabeça, os olhos desproporcionais à face a ponto de se situarem fora do perímetro do crânio, além da desproporção da boca e dos dentes, constroem a imagem de uma lagarta ${ }^{32}$, enquanto o corpo mantém os traços que identificam uma figura feminina caracterizada tanto pela sinuosidade dos traços corpóreos como pelos sapatos de saltos altos. A semicobertura dos seios e outras partes do corpo que devem ser cobertas deveu-se à interdição

32 Tal fenômeno não é exclusivo deste discurso. Em BROSSAT, A. Le Corps de l'ennemi: byperviolence et démocratie. Paris: La Fabrique, 1998, o autor discute o que chama de "animalização da política", ou "zoopolítica", no contexto francês, ou seja, trata-se de um discurso, cuja construção do inimigo utiliza-se, não raro, de metáforas animalescas tais como "raposa, rato, cão, lobo etc." 
do primeiro folheto, no qual constava uma figura demoníaca desnuda.

Quando a candidata petista é representada por uma lagarta, ativam-se na memória de quem vê a imagem dizeres outros ditos e esquecidos em outros lugares de fala. Por exemplo, no âmbito da agricultura, a lagarta é uma praga, um elemento indesejável, o inimigo natural das plantações, o que as destrói. Dessa forma, se a bandeira com o símbolo de comunismo está nas mãos de uma lagarta, o antimodelo político dessa vertente ideológica é construído a partir dessa metáfora, do deslizamento do sentido, da transferência de sentidos do universo da agricultura para o campo político. A foice e o martelo, símbolos do comunismo cunhados no século XIX, no interior da III Internacional Comunista, que significam a união dos trabalhadores do campo com os da cidade, funcionam ainda hoje como símbolo dos partidos alinhados com essa ideologia política. Não obstante, em face da não transparência dos sentidos - que podem ter diferentes significações quando enunciados em diferentes lugares da fala, - no contexto histórico de Juazeiro a utilização desses símbolos vai fazer falarem, por exemplo, os discursos do Padre Cícero contra o "comunismo ateu", e toda uma rede de dizeres em torno da demonização do comunismo será mobilizada. ${ }^{33}$

33 Este discurso anticomunista tem precedentes na história. Foi utilizado pelos nazistas para perseguir as pessoas dessa corrente ideológica, bem como para perseguir judeus, ciganos e homossexuais. No Brasil foi utilizado pelo governo de Getúlio Vargas para reprimir oponentes. Conheceu, porém, o seu apogeu, no período da ditadura militar, por causa da Doutrina de Segurança Nacional. Sobre o discurso dos militares no Brasil Ver FIORIN, J.L. O regime de 1964: discurso e ideologia. São Paulo: Atual, 1988 e INDURSKY, F. A fala dos quartéis e outras vozes. Campinas: Editora da UNICAMP, 1997. No Nordeste há um forte imaginário anticomunista, propagado tanto pelos partidos de direita como pelas religiões. A crença de que comunistas comem crianças, por exemplo, ainda subsiste. Em Juazeiro do Norte, nas eleições de 1989 para presidente foram espalhados na cidade boatos de que o então candidato Lula da Silva iria mudar a bandeira do Brasil, torná-la vermelha, que 
Outro aspecto dessa relação com a memória é a presença do caldeirão e da colher, a qual constrói uma relação entre o espaço público e o privado no tocante à figura feminina. É mediante a mobilização de um pré-construto de representação da mulher na sociedade patriarcal como inscrita no domínio doméstico que se torna possível perceber o efeito de sentido da imagem da colher, instrumento que pertence ao campo semântico de 'cozinha', lugar atribuído, nos discursos sexistas, ao gênero feminino. A colher e o caldeirão evocam o espaço doméstico, fazendo falar enunciados vivos na memória discursiva do leitor do tipo 'lugar de mulher é na cozinha'. Considerando-se, assim, o contexto em que essa mulher concorria a um cargo público, este seria incompatível com o gênero feminino. Assim, a imagem concorre para 'lembrar' qual é o lugar da mulher. O caldeirão evoca, ainda, outra representação feminina indesejada: a das denominadas 'bruxas' no discurso da Igreja Católica Medieval. Nesse contexto histórico, toda mulher poderia ser considerada bruxa, visto que as ligações demoníacas estão associadas ao gênero feminino desde o mito de Adão e Eva, em que esta conduziu aquele ao pecado, passando por toda uma rede de dispositivos sociais e institucionais. ${ }^{34}$

iria destruir a estátua do Padre Cícero. Ademais, em todas as eleições, este discurso retorna de diferentes formas, a depender do candidato. Em 2000, moradores de bairros periféricos da cidade contam ter recebido em suas casas estátuas do Padre Cícero pintadas de vermelho como se tivessem sido entregues pelo PT.

34 Não só as religiões representaram a mulher como ser que deve obediência e "aprender em silêncio, com toda a sujeição" (I Tim 2:11). Também o Direito, a Filosofia e a Medicina justificaram por muito tempo, a desigualdade entre os gêneros. Dizia Ambroise Paré, renomado cirurgião francês do século XVI, em sua Anatomie Universelle du Corps: "Se os órgãos sexuais da mulher são internos, contrariamente aos do homem, isso se deve à 'imbecilidade' de sua natureza que não pôde expelir e lançar fora as ditas partes, como no homem". O filósofo Aristóteles (384-322 a.C.) via o gênero feminino como um defeito da natureza, "um 
Outro elemento possível de identificar na imagem é a disposição das pernas abertas da figura, o que também é constitutivo de uma representação indesejável da mulher, de acordo com toda uma tradição profundamente marcada pela ética cristã, que atribui os valores de recato e obediência a este gênero, e também com os manuais de etiqueta social, os quais apresentam as formas elegantes de se portar, de sentar, e segundo os quais sentar-se com as pernas abertas não faz parte dos dispositivos sociais de construção da subjetividade pública feminina em nenhuma época.

Desta forma, ao associar os símbolos do comunismo e um corpo feminino com "cabeça de lagarta", produz-se também um jogo de verdade/falsidade. O comunismo é falado diferentemente, de forma ressignificada, atualizando falas tanto do discurso bíblico - "Satanás é o mestre do disfarce e procura constantemente falsificar as verdades de Deus" (São Paulo, Epístola aos Coríntios 11:13-15) - como dos sermões do Padre Cícero, o qual dizia que "a besta pode assumir muitas faces, muitas vezes, até a de uma bela mulher".

É por essa via que tais elementos vão adquirir outros efeitos de sentido, na perspectiva de desqualificação do discurso da candidata petista. Ao atribuir a essa candidata o discurso comunista por meio do símbolo associado a uma lagarta, bichinho que destrói as plantações, produz-se um efeito de sentido de que aquela candidata "comunista" seria a destruição de algo sólido, já "plantado", já instituído.

macho mutilado". In: LUCAS, A. A mulher e a política. http://www.brejo.com/b8/ler. coluna.php?ArtID=270\&page=1, pesquisado em 28/02/2010. 


\section{Considerações finais}

De acordo com Foucault (1999, p. 97), "o sujeito não preexiste ao discurso, ele é construído/constituído no e pelo discurso". Nessa perspectiva, pudemos verificar os mecanismos de constituição de identidade do sujeito político feminino a partir de uma materialidade imagética, a xilogravura, atuando no sentido da desqualificação do discurso da candidata do PT nas eleições para prefeito de Juazeiro do Norte - Ceará, em 2000. Essa desqualificação ocorre por meio da construção de um antimodelo de candidatura, o comunista e feminino; ou seja, pelo discurso da imagem, um sujeito político qualificado para o cargo de prefeito seria alguém não comunista e não mulher, o que faz emergirem discursos misóginos e anticomunistas pronunciados em outros lugares de fala. Para a construção desse discurso, a imagem mobiliza, num processo de intericonicidade, aquilo que fala alhures, ativando, na memória discursiva de quem vê a imagem, elementos como a lagarta, a foice e o martelo, o caldeirão e a colher. No âmbito da agricultura, a lagarta é uma praga que destrói plantações, e no discurso político em tela esse sentido é deslocado, produzindo o efeito de sentido de que aquela prática discursiva "comunista" seria a destruição de algo sólido, já "plantado", já instituído, significando que na "lavoura" política de Juazeiro a candidata do PT, tanto por ser mulher quanto por ser "comunista", atuaria como elemento destruidor do que já estaria solidificado. Para o presente trabalho recortamos a xilogravura de cordel e a colocamos em diálogo com outros dizeres para demonstrar que esta imagem faz irromperem, de forma realçada, falas pronunciadas/impronunciáveis, ativando elementos da memória coletiva e ressignificando-os no domínio de atualidade. Não obstante, pensamos que, em face da 
"sociedade do espetáculo" (DEBORD, 1997), em que a imagem, com seus textos sincréticos, adquire importância ímpar, essa aproximação da Análise do Discurso com o que J.J. Courtine vem denominando de Semiologia Histórica abre um imenso leque de possibilidades de análise das mais variadas materialidades, na busca do funcionamento dos discursos contemporâneos no intrincado e complexo encontro da língua (em sentido amplo) com a história, espaço no qual os sujeitos se constituem/são constituídos e (re)fazem sentido(s).

\section{Referências}

BÍBLIA SAGRADA. Edições Paulinas. São Paulo, s/d.

BONNAFOUS, S. Sobre o bom uso da derrisão em J.M. Le Pen. In:

BROSSAT, A. Le Corps de l'ennemi: hyperviolence et démocratie. Paris, La Fabrique, 1998, p. 35-48.

CHARTIER, R. A ordem dos livros: leitores, autores e bibliotecas na Europa entre os séculos XIV e XVIII. Brasília,:Ed.da Universidade de Brasília, 1990.

CASCUDO, L.C. Cinco livros do povo. 3. ed. João Pessoa: Ed. da Universidade Federal da Paraíba, 1994.

COURTINE, J.:VIGARELLO, G. A História do corpo: as mutações do olhar. v. 3,. Petrópolis: Vozes, 2006, p. 341-361

COURTINE, J.-J. Analyse du discours politique: le discours communiste adressé aux chrétiens. Languages, n. 62, pp 9-128. Paris: Larousse, 1981.

O discurso inatingível: marxismo e linguística (1965-1985). Cadernos de Traducão. n. 6, p. 5-18. Porto Alegre, 1999.

DEBORD, G. A sociedade do espetáculo. Rio de Janeiro: Contraponto, 1997. 
DIEGUES JR., M. Literatura de cordel. Cadernos de Folclore, n. 2. Rio de Janeiro, 1975.

FIORIN, J.L. O regime de 1964: discurso e ideologia. São Paulo: Atual, 1988.

GRANGEIRO, C.R.P. O discurso religioso na literatura de cordel de Juazeiro de Norte. Crato: A Província, 2002.

GRANGEIRO, C.R.P. Transformações do fazer a Lira Cordelina. Juazeiro do Norte, 2006. Mimeo.

GRANGEIRO, C.R.P. Foucault, Pêcheux e a formação discursiva In: BARONAS, R. L. (Org.) Análise do discurso: apontamentos para uma história da noção-conceito de formação discursiva. São Carlos-SP: Pedro e João, $2007 \mathrm{a}$.

GRANGEIRO, C.R.P. Discurso politico no folheto de cordel: A "besta-fera", o Padre Cícero e o Juazeiro. Tese de Doutorado. UNESP/Faculdade de Ciências e Letras de Araraquara (SP), 2007b.

GREGOLIN, M. R.V. Foucault e Pêcheux na construção da análise do discurso: diálogos e duelos. São Carlos: Claraluz, 2004.

FOUCAULT. M. Resumo dos cursos do Collège de France. Rio de Janeiro: Jorge Zahar, 1997. - A arqueologia do saber. Rio de Janeiro: Forense Universitária, 1999. Ditos e Escritos: Ética, Sexualidade, Política. Vol. 5. Rio de Janeiro: Forense Universitária, 2004.

INDURSKY, F. A fala dos quartéis e outras vozes. Campinas: Ed. da UNICAMP, 1997.

LOPES, J.R. Literatura de cordel: antologia. Fortaleza: BNB, 1982.

LUCAS, A. A mulher e a politica. Disponível em: <http://www.brejo.com/b8/ ler.coluna.php?ArtID=270\&page=1>. Acesso em: 28 fev. 2010 .

MILANEZ, N. O corpo é um arquipélago: memória, intericonicidade e identidade. In: NAVARRO, P. (org.) Estudos do texto e do discurso: mapeando conceitos e métodos. São Carlos: Claraluz, 2006, p. 153-179. 
NORA, P. Paris: La Nation. Vol. 1, 1993.

PÊCHEUX, M. Papel da memória In: ACHARD, P. et al. Papel da memória. Campinas-SP: Pontes, 1999.

Semântica e discurso: uma crítica à afirmação do óbvio. 3 ed.

Campinas: Editora da UNICAMP, 1997.

SANTOS, F. P. Novas cartografias no cordel e na cantoria: desterritorialização de gênero nas poéticas das vozes. Tese de Doutorado. UFPB. João Pessoa, 2009. 



\title{
MEMÓRIA, MULHER E POLÍTICA: DO GOVERNO DAS CAPITANIAS À PRESIDÊNCIA DA REPÚBLICA, ROMPENDO BARREIRAS \\ Maria da Conceição Fonseca-Silva ${ }^{35}$
}

\begin{abstract}
A partir do momento em que há uma relação de poder, há uma possibilidade de resistência. Jamais somos aprisionados pelo poder: podemos sempre modificar sua dominação em condições determinadas e segundo uma estratégia precisa.
\end{abstract}

(Foucault, Microfísica do Poder)

\section{Considerações gerais}

$\mathrm{O}$ interesse das mulheres pela vida pública e a luta pela representação política marcam um processo difícil e têm sido objeto de estudo de pesquisadores de diversas áreas do conhecimento, dado o caráter multifacetado do objeto.

Em sua obra, Foucault afirma que nossas sociedades desenvolveram modos de objetivação que transformam os indivíduos em sujeitos (objetos) dóceis e úteis e modos de

35 Professora do Departamento de Estudos Linguísticos e Literários e dos Programas de PósGraduação em Linguística e em Memória: linguagem e sociedade da UESB. 
subjetivação que transformam os indivíduos em sujeitos presos a identidades que lhes são atribuídas como próprias. Como dissemos em Fonseca-Silva (2007a; 2008), no Brasil, até a metade do século XIX o percentual de mulheres alfabetizadas era muito pequeno e o analfabetismo era símbolo de nobreza e virtude para as mulheres, as quais, mantidas em situação de ignorância, não podiam participar da vida pública. Enquanto os homens eram preparados para seguir uma carreira, com disciplinas que incluíam todo o conhecimento científico e humano da época, as mulheres que tinham oportunidade de estudar recebiam instruções de português e de francês, das quatro operações matemáticas básicas, mas, principalmente, aulas de bordado. Esses são, a princípio, alguns dos 'modos de objetivação', no sentido postulado por Foucault (1982), que transformavam homens e mulheres em sujeitos.

Ressaltamos, não obstante, que quando os indivíduos são colocados em objetivações ou subjetivações, são também colocados em complexas relações de poder, as quais, na perspectiva foucaultiana, produzem saber e inserem-se nos gestos, atitudes e discursos que permeiam as sociedades. $\mathrm{O}$ poder de que trata $\mathrm{o}$ autor não se reduz à opressão e dominação, mas produz saber; e, de acordo com a explicação de Deleuze (1992, p. 50), esse poder funciona como um "conjunto dos relacionamentos de forças, conjunto que não passa menos pelas forças dominadas que pelas dominantes, umas e outras constituindo singularidades". Esse poder encontra-se em toda a rede do corpo social. É neste sentido que, na perspectiva foucaultiana, onde há poder há resistência, pois "[...] jamais somos aprisionados pelo poder: podemos sempre modificar sua dominação em condições determinadas e segundo uma estratégia precisa" (FOUCAULT, 1979, p. 24).

Isto implica que, no interior da racionalidade política, gerações de mulheres brasileiras, independentemente de sua raça 
ou classe social (índias, negras, brancas, ricas ou pobres, famosas ou anônimas, livres ou escravas), na Colônia, no Reinado, no Império, na República e nos dias atuais, estiveram ou estão nesse conjunto de relacionamentos de forças, lutando e promovendo contracondutas individuais e coletivas (ações e movimentos que se opõem às formas de conduta no interior de uma racionalidade política), no que tange aos modos de objetivação e de subjetivação de homens e mulheres em todos os gestos das esferas pública e privada. As condições de possibilidade de cada época justificam, em parte, o silêncio que, conforme Perrot (2005), é promovido pelas religiões, pelos sistemas políticos e pelos manuais de comportamento, cuja lista de verbos no imperativo incluía termos como 'aceite', 'conforme-se', 'obedeça', 'submeta-se' e 'cale-se'. Essas injunções não foram aceitas por milhares de mulheres brasileiras que se colocaram no lugar de resistência, muitas das quais ficaram anônimas, outras tantas foram esquecidas e poucas são lembradas.

\section{Da Colônia à República: memória, poder político e mulheres construindo identidades}

No século XVI, período da colonização do Brasil, algumas mulheres, esposas de donatários, governaram com sucesso capitanias hereditárias, representando o rei de Portugal na colônia com plena autoridade tanto no campo judicial (para aplicar a lei) quanto no campo administrativo (para nomear funcionários). Merecem destaque: Ana Pimentel, esposa de Martim Afonso de Souza, donatário da Capitania de São Vicente, que por ela foi administrada, a partir de 1534, por mais de uma década; Brites 
Mendes de Albuquerque, esposa de Duarte Coelho Pereira, donatário da Capitania de Pernambuco, que por ela foi governada a partir de 1554; e Luisa Grimaldi, esposa de Vasco Fernandes Coutinho Filho, donatário da Capitania do Espírito Santo, por ela comandada a partir de 1589. No final do século XVI e início do XVII algumas mulheres atuaram como bandeirantes ou sertanistas, entre elas: Ana de Oliveira, que participou da formação de duas bandeiras ao lado do marido e irmãos, com o objetivo de conquistar terras no sertão paraibano; Maria Diaz Ferraz do Amaral, que lutou ao lado dos homens num confronto contra os índios Caiapó no interior de Goiás; e Ana Bastarda, que, para afirmar a sua condição de mulher livre, condição sempre ameaçada por ser índia, deixou um testamento. Ainda no século XVII, destacaram-se a Iguaçu, índia da nação Tamoio, que, ao lado dos franceses, lutou na disputa pelo domínio das terras da Baía de Guanabara; Inês de Souza, que, na luta contra os corsários franceses em defesa da cidade do Rio de Janeiro, reunia mulheres e crianças, vestindo-as com armaduras masculinas para que simulassem manobras de defesa na praia; Ana Paes d'Altro ou Ana de Holanda, dona de um engenho que abrigava as mulheres e filhas dos principais líderes da revolta pernambucana contra o domínio holandês no Brasil e que foi palco de um dos combates mais violentos da guerra contra os holandeses. No século XVIII, Hipólita Jacinta Teixeira de Mello, letrada e dotada de vasta cultura, participou da conspiração de Vila Rica Morro, dispondo uma de suas fazendas para reuniões dos inconfidentes.

No século XIX, acontecimentos políticos como a chegada da família real ao Brasil, a proclamação da independência, revoltas, movimentos sociais e políticos de reivindicação, a abolição da escravatura e a proclamação da República - foram marcados pela participação de mulheres. Entre essas mulheres destacaram-se, 
na primeira metade do século XIX, no Ceará, em 1817, Bárbara Pereira de Alencar, pela participação da revolução republicana no Nordeste; em Alagoas, em 1822, Ana Lins, pela participação na revolta conhecida como Confederação do Equador; na Bahia, em 1824, Maria Felipa, escrava, que, na luta pela independência da Bahia, liderou 40 mulheres conhecidas como as vigias da praia, que invadiram o acampamento do exército português, atacaram os guardas e atearam fogo às embarcações; e Maria Quitéria, por ter participado das batalhas pela independência; no Rio Grande do Norte, em 1832, Nísia Floresta ${ }^{36}$, que, aos 22 anos, publicou "Direitos das mulheres e injustiças dos homens", primeiro artigo em que tratou dos limites entre os espaços público e privado, exigindo o direito de igualdade e educação para todas as mulheres; no Rio Grande do Sul, entre 1833 e 1834, Ana de Barandas, Delfina Benigna da Cunha e Maria Josefa Barreto, entre outras mulheres, se opuseram à Revolução Farroupilha e defenderam a participação das mulheres na luta política contra os partidários da separação da Província do Rio Grande do Sul.

Ressaltamos, em Fonseca-Silva (2007a), que somente a partir da segunda metade do século XIX algumas mulheres brasileiras deixaram o Brasil para estudar no exterior, pois no país o ensino superior só foi estendido às mulheres a partir de 1879. Nesse período, mulheres que tiveram acesso à educação no exterior retornaram, lutaram pelos direitos da mulher e passaram a reivindicar, também, direitos políticos, dando início ao movimento sufragista, para o qual o voto estava vinculado à igualdade da mulher e aos direitos humanos gerais, como a

36 Alem de publicar Direitos das mulberes e injustiça dos bomens, em que trata dos direitos das mulheres à instrução e ao trabalho, publicou Conselhos a minha filha, em1842; Opúsculo bumanitário, em 1853; A Mulher, em 1859, destancando a importância da educação feminina para a mulher e a sociedade. Engajou-se também na luta pela abolocionismo. 
abolição. Como exemplos destacamos, no Rio de Janeiro, Narcisa Amália - primeira mulher jornalista -, que alcançou projeção no Brasil com seus artigos, por meios dos quais lutava pela abolição da escravatura, pela defesa da mulher e dos oprimidos em geral, e defendia a ideia de que, sem a instrução do povo, a democracia não passaria de uma dourada quimera; e Izabel de Souza Matos, a qual, em 1885, apoiada na Lei Saraiva, promulgada em 1881, que estabelecia as primeiras eleições diretas e garantia o voto a quem tivesse título científico, requereu alistamento eleitoral e foi atendida em seu pedido; mas aconteceu que, com o advento da República, o Ministro do Interior deu um parecer contrário, julgando o pedido improcedente.

No final do século XIX algumas mulheres criaram organizações dedicadas à causa abolicionista: Maria Tomásia Figueira presidiu a "Sociedade das Senhoras Libertadoras" ou "Cearenses Libertadoras", criada em 1882, em parceria com Maria Correia do Amaral; Elvira Pinho fundou associações em Fortaleza e no interior do Estado, em favor da liberdade, contribuindo para que a Assembleia Legislativa Provincial decretasse o fim da escravidão no Ceará, em 1884; Elisa de Faria Souto, Olímpia Fonseca e Filomena Amorim criaram, em 1884, a associação "Amazonenses Libertadoras", com o intuito de defender a emancipação de todos os escravos do solo amazonense, atingindo o objetivo um ano antes da Lei Áurea, em 30 de março de 1887.

Destacamos igualmente Adelina, filha de uma escrava e de seu proprietário, um homem que a obrigava a vender nas ruas da capital maranhense os charutos que fabricava. Como sabia ler e escrever, aos 16 anos frequentava comícios da sociedade abolicionista Clube dos Mortos e, consciente da sua causa, utilizava o seu trabalho para descobrir com antecedência 
os planos da polícia sobre a perseguição a escravos fugidos e informar os companheiros, ajudando-os na articulação das fugas de escravos.

O século XX é marcado pela luta das mulheres em prol da conquista da cidadania. Patrícia Galvão, em 1922, desmistificando a figura feminina fora do espaço doméstico, publicou Parque industrial, em que denunciava as péssimas condições de salubridade dos operários imigrantes, os quais trabalhavam por mais de doze horas nas fábricas de São Paulo.

No início da década de 1920 surgiram vários grupos, denominados "Ligas para o Progresso Feminino", o embrião da "Federação Brasileira pelo Progresso Feminino", fundada em 1922, que, liderada por Bertha Maria Júlia Lutz, teve papel decisivo na conquista do sufrágio feminino. Conforme Avelar (2002, p. 45), as sufragistas eram "médicas, dentistas, advogadas, escritoras, escultoras, poetisas, pintoras, engenheiras civis, cientistas, funcionárias públicas, parentes de políticos da alta elite".

No Rio Grande do Norte, em 1927 foi elaborada e aprovada a Lei Eleitoral N. ${ }^{\circ}$ 660, com uma emenda que estendia a todos os cidadãos que reunissem as condições exigidas, sem distinção de sexo, o direito de votar e ser votado. Conforme Daniel e Pereira (2009), várias mulheres requereram inscrição eleitoral. No dia 25 de novembro de 1927, Celina Guimarães obteve seu registro e se tornou a primeira eleitora do Brasil. No dia 5 de abril de 1928, Alzira Soriano foi eleita prefeita de Lajes, tornando-se a primeira mulher no Brasil escolhida pelo voto para ocupar um cargo eletivo, na esfera do poder executivo; mas a Comissão de Poderes do Senado impediu que ela concluísse o mandato e anulou todos os votos das mulheres alistadas no Estado. 
Com a Revolução de 30, as feministas se uniram a Vargas para discutir o Anteprojeto da Constituição de 1932, e conseguiram que Berta Lutz fosse indicada pelo presidente para discutir o parecer. Houve então uma manobra para retirar do anteprojeto o direito de voto às mulheres, mas o presidente antecipou a divulgação do documento e fez publicar o Código Eleitoral Provisório, instituído pelo Decreto N. ${ }^{\circ} 21.076$, de 24 de fevereiro de 1932, (FONSECASILVA, 2007a, p. 22), o qual garantia o voto a mulheres casadas com autorização do marido e a viúvas e solteiras que tivessem renda.

Essas restrições só foram eliminadas no Código Eleitoral de 1934, que, segundo Blay (2001), tornou apenas o voto masculino obrigatório. Carlota Pereira de Queiroz foi a primeira deputada federal eleita no Brasil, e em 1934 Joanna da Rocha Santos foi eleita prefeita da cidade de São João dos Patos, no Maranhão, tornando-se a segunda prefeita eleita do País.

Com o advento da Ditadura do Estado Novo (1937-1945) e o consequente fechamento do Congresso por Getúlio Vargas, em 1937, as mulheres só puderam votar com a redemocratização do país; e o voto feminino só passou a ser obrigatório em 1946, quando o sistema democrático brasileiro começou a ser restabelecido. A Câmara dos Deputados e o Senado passaram a funcionar como Poder Legislativo durante o Governo Dutra (1946-1951), que baixou o decreto conhecido como Lei Agamenon, instituindo a Justiça Eleitoral, o alistamento eleitoral e os pleitos. Em 1947 Conceição da Costa Neves foi eleita a primeira deputada estadual, e foi também a primeira mulher, em todo o Brasil, a assumir a presidência de uma assembleia legislativa. 
No período da ditadura militar, cujo início é marcado pelo ano de 1964 e apoiado por setores da sociedade civil ${ }^{37}$ como os industriais, os banqueiros, o clero, parte da classe média e militares de alta patente, o processo eleitoral foi adequado aos interesses do regime, que alterou a duração de mandatos, cassou políticos, decretou eleições indiretas para os cargos de presidente da República e governador de Estado e a nomeação de prefeitos. A legislação eleitoral ficou marcada pela centralização do poder e das decisões na figura do presidente, reforçada pela implantação de vários atos institucionais, quais sejam: AI 1 (1964), que permitiu a cassação de mandatos e a suspensão de direitos políticos; AI 2 (1965), que extinguiu partidos políticos, determinou eleições indiretas, decretou estado de sítio sem consulta prévia do Congresso Nacional e intervenção nos estados, e fechou o congresso; AI 3 (1966), que determinou eleições indiretas para governador e nomeação de prefeitos; AI 4 (1966), que obrigou o congresso a votar o Projeto da Constituição; AI 5 (1968), que ampliou os poderes do presidente da República, permitindo-lhe decretar o fechamento do Congresso Nacional. Em 1969 foi instituída nova lei de segurança nacional; em 1970 foi aprovado o Decreto-Lei N. ${ }^{\circ}$ 1077, que instituiu a censura; em 1976 foi instituída a Lei N. ${ }^{\circ} 6.339$ (Lei Falcão), que restringiu a propaganda eleitoral e proibiu o debate político nos meios de comunicação; em 1977 foi aprovada a Emenda Constitucional no 8, que criou a categoria de "senador biônico", eleito indiretamente por um colégio eleitoral que era controlado pelos militares. As formas de repressão e intimidação da ditadura incluíam a proibição

37 A Marcha da Família com Deus pela Liberdade, que reuniu cerca de quinhentas mil pessoas na Praça da República, centro de São Paulo, indica que houve organização de setores da sociedade civil para depor João Goulart do poder, pois defendiam a intervenção militar na política. 
de opiniões contrárias ao regime, prisões, torturas, exílios e assassinatos premeditados (SILVA, 1988).

Conforme Ventura (1988), logo após o golpe militar de 1964 teve início uma fase de silêncio forçado dos movimentos de massa. A partir de então, as lutas estudantis se intensificaram em resistência tanto ao projeto de reforma educacional proposto pela ditadura quanto à repressão policial-militar e atos institucionais. Em consequência, o confronto saía do campo das ideias para as ruas, com a luta armada, e para os porões, lugar onde acontecia a prática de tortura. Isto significa que, com a ideologia da segurança nacional imposta pelo regime militar, era impossível conjugar o ideário de libertação difundido por qualquer segmento intelectual, artístico, estudantil ou operário. Parte da população brasileira, incluindo homens e mulheres, declarou, por meio de luta contra a ditadura militar, a não aceitação de um regime político repressor. Muitas mulheres, em sua maioria jovens da classe média e intelectualizadas, engajaram-se em movimentos e organizações clandestinas de esquerda e lutaram pela recuperação dos direitos civis e políticos, nas décadas de 60 e 70 até inicio da década de 80 . Além de lutar pela igualdade de direitos, as mulheres, ao lado dos homens que participavam dos movimentos e organizações clandestinas, lutavam também pela redemocratização do país, pela anistia aos presos políticos e por melhores condições de vida, sendo taxadas pelo regime como subversivas e terroristas. $\mathrm{Na}$ lista de nomes de mulheres figura 'Dilma Rousseff'.

Ao tratar da relação entre mulher e política no período entre os anos 60 e 70 do século XX, especificamente, sobre aspectos da militância feminina em organizações clandestinas contra o regime militar brasileiro, Bastos (2004, p. 1) afirma que "as transformações sociais ocorridas na sociedade brasileira, 
especialmente a partir dos anos 60, criaram as condições mais gerais para a efetiva constituição da 'mulher como sujeito político" na luta pela transformação das relações sociais e políticas. Ridenti (1990) salienta que na década de 1970 as mulheres militantes correspondiam a $16 \%$ dos quadros das organizações de esquerda e a 18,3\% do total de militantes armados.

A partir da década de 80 a participação da mulher na política brasileira intensificou-se. Maria Luiza Fontenele, em Fortaleza, tornou-se a primeira prefeita de uma capital, em 1986, e Iolanda Fleming, do Acre, tornou-se a primeira governadora, no mesmo ano. Luiza Erundina, em São Paulo, foi a primeira prefeita da maior cidade do país, em 1989; e Júnia Marise Azeredo Coutinho, em Minas Gerais, e Marluce Pinto, em Roraima, foram as primeiras senadoras eleitas por voto direto, em 1990, Sendo seguidas por Roseana Sarney, eleita senadora pelo estado do Maranhão em 1994. Ellen Gracie Northfleet tornou-se a primeira mulher a integrar (como ministra) a Suprema Corte do Brasil desde a sua criação, em 2002, e a primeira presidente eleita do Supremo Tribunal Federal, em 2006. Dilma Rousseff, depois de ter sido presa, torturada e taxada pelo regime militar como subversiva e terrorista, tornou-se a primeira mulher a ocupar a função de Ministro das Minas e Energia, em 2003, a função de Chefe da Casa Civil (equivalente ao cargo de primeiro-ministro), em 2005, e a primeira presidente do Brasil, em 2010.

O século XXI desponta, assim, com acontecimentos marcados pela memória e atualidade do papel político da mulher no jogo de relações de forças no processo de transformação social, no que tange à superação das desigualdades de gênero e das relações com as diferentes esferas de poder. 


\section{Dilma Rousseff: de militante a presidente}

$\mathrm{Na}$ discursivização da mídia, Dilma Rousseff representa a mulher que atua nas esferas de poder político e que está relacionada ao mesmo tempo à militância política e à luta armada no Brasil. $\mathrm{Na}$ análise das formulações que selecionamos para trabalhar este tópico, mobilizamos o conceito de efeito metafórico definido por Pêcheux (1969) como efeito semântico por um deslizamento de sentido numa distância entre X e Y. Para o autor, as sequências discursivas não se passam a outras apenas por substituição, pois estão ligadas por uma série de efeitos metafóricos. Argumenta o autor que a metáfora não funciona nem como comparação nem como desvio, mas como transferência que se dá num processo contínuo de deslizamentos por meio do qual se pode chegar tanto ao lugar da interpretação quanto ao lugar da historicidade. Dito de outra forma, de um lado, palavras, expressões, etc., não significam por si sós; de outro lado, não há sentido sem metáfora, pois o sentido se delineia sempre na relação que uma palavra ou uma expressão tem com outra palavra ou outra expressão.

O efeito metafórico, segundo Pêcheux (1969), assenta-se na tensão entre processos parafrásticos (o mesmo) e polissêmicos (o diferente). A paráfrase figura como reformulação ou como atividade efetiva de reformulação; a polissemia, por seu turno, definida como o deslocamento, como a ruptura na continuidade perpetrada pela paráfrase, como solução da continuidade do processo de significação mantida pela paráfrase, contrapõese à paráfrase, pois joga permanentemente com o equívoco. A polissemia caracteriza-se pela emergência do diferente, da multiplicidade de sentidos no discurso, e pode ser percebida 
em diferentes situações de discursividade, como se observa na seguinte discursivização sobre Dilma Rousseff:

1. Dilma Rousseff tem fama - e biografia - de durona. Mas como esse é um governo de lágrimas fáceis e abundantes, ao ser empossada, ela caiu no choro ao se lembrar das companheiras de luta armada mortas durante o regime militar. Dilma foi militante do Comando de Libertação Nacional (Colina) e da Vanguarda Popular Revolucionária (VPR). Codinomes que usava na época: Estela, Luiza, Patrícia e Wanda. (Veja, 8 de janeiro de 2003, p. 35 - grifos nossos).

2. A ex-guerrilheira abre fogo. (Veja, 2 de novembro de 2005, p.80 - grifos nossos).

3. A manutenção dessas conquistas - mérito que, este, sim, cabe ao governo Lula e à equipe de Palocci - é justamente o que a ministra (e ex-guerrilheira da VAR-Palmares, um dos principais grupos armados da década de 60) [...] (Veja, 2 de novembro de 2005. p. 8283 - grifos nossos).

As expressões destacadas em negrito nas formulações de 1 a 3 podem ser agrupadas na série (a):

(a)

Dilma Rousseff tem fama e biografia - de durona.

ela caiu no choro ao se

lembrar das companheiras

de luta armada mortas

durante o regime militar.

Dilma foi militante do

Comando de Libertação

Nacional (Colina) e da

Vanguarda Popular

Revolucionária (VPR).

Codinomes que usava 
na época: Estela, Luiza,

Patrícia e Wanda.

A ex-guerrilheira abre fogo.

a ministra (e ex-guerrilheira

da VAR-Palmares, um dos

principais grupos armados

da década de 60).

$\mathrm{Na}$ rede apresentada em (a), em que ocorre o jogo do mesmo e do diferente, ou seja, um jogo parafrástico e polissêmico, as expressões em negrito funcionam como pontos de encontro de uma memória e de uma atualidade. Indicam que Dilma se subjetivou na posição de militante contra o regime militar e atualmente se subjetiva na esfera do Poder Executivo no Brasil. Indica que houve participação feminina na militância política contra a ditadura militar brasileira, quando jovens estudantes assumiram um papel inédito tanto no campo da política quanto no campo das relações de gênero, rompendo com os códigos da época. Nos anos tensos da ditadura militar, Dilma Rousseff, que iniciou a sua militância política antes de 1964, no movimento estudantil, aos 16 anos, foi uma das jovens estudantes que tiveram importante atuação: militou no Comando de Libertação Nacional (COLINA) e na Vanguarda Armada Revolucionária Palmares (VAR-Palmares).

Conforme Pêcheux (1983, p. 53), toda descrição está exposta ao equívoco da língua. Isso implica que todo enunciado ou formulação linguística é "suscetível de tornar-se outro, diferente de si mesmo, se deslocar discursivamente de seu sentido para derivar para um outro". Daí que, ao discursivizar sobre Dilma na condição de ministra e designá-la com expressões que remetem à sua participação no passado em 
movimentos e organizações que lutaram contra a ditadura, a mídia - (neste caso, a Revista Veja, em cujas páginas circularam textos com formulações do tipo das apresentadas de 1 a 3) não a desqualifica, ainda que tenha sido essa a intenção do semanário mais vendido no Brasil; ao contrário, ajuda o país a não esquecer e contribui para o não apagamento de acontecimentos que fazem parte da memória social brasileira, já que muitos dos homens e mulheres que, quando jovens, militaram contra o regime militar, não puderam e não podem contar suas histórias. A história da ditadura militar é pouco discursivizada nos meios de comunicação, como também o é no que tange à história das mulheres, havendo um silenciamento neste sentido. O silêncio, porém, nem sempre é negativo. Orlandi (1992) argumenta que o silêncio não é uma contrapartida do dito visto de forma negativa, mas é o que rege os processos de significação e que tem formas específicas de significar, pois dizer e silenciar são constitutivamente inseparáveis, e para dizer é necessário não dizer, já que todo dizer cala algum sentido. Segundo a autora, a política do silêncio indica como o sentido é sempre produzido de um lugar e a partir de uma posição de sujeito.

Dessa forma, já que todo processo de significar traz uma relação com o silêncio, podemos dizer que no trabalho de memória - marcado pela tensão do jogo do mesmo e do diferente nos processos parafrásticos e polissêmicos identificados nas expressões de (a) - houve participação feminina nas organizações de militância política e nos movimentos de guerrilha e que Dilma Rousseff participou dessas organizações. Essa participação provocou ruptura na história do país, provando que, assim como o homem, a mulher pode combater e conquistar reconhecimento e respeito no espaço político. 
Disto resultou que, nas eleições para presidente do Brasil em 2010, dos três principais candidatos, no primeiro turno, dois eram mulheres: Marina Silva e Dilma Rousseff, que obtiveram, juntas, $66 \%$ dos votos. O segundo turno foi disputado por José Serra e Dilma Rousseff, e esta última obteve a vitória, com $56,04 \%$ dos votos válidos.

Na noite de 31 de outubro de 2010, marcado pela novidade do acontecimento 'Dilma Rousseff foi eleita a primeira presidente do Brasil', teve início, a partir das 20 horas, quase simultaneamente, nas TVs, sites de notícias e jornais online do Brasil e de outros países, como um grito quase coletivo, a circulação-confronto, no sentido de Pêcheux (1983), de formulações (deslocadas, repetidas e retomadas) que se colocam no jogo parafrástico e polissêmico, a exemplo das apresentadas a seguir:

4. Atenção! Nos próximos 4 anos e pela primeira vez na história, o poder executivo do Brasil será comandado por uma mulher. Dilma esta oficialmente eleita Presidente da República (Rede Globo, 31 de outubro de 2010).

5. Domingo, 31 de outubro de 2010. Uma data histórica para 192 milhões de Brasileiros. Pela primeira vez, uma mulher é eleita presidente do Brasil. Dilma, mineira, economista, 62 anos. O Brasil ganhou a sua primeira presidente mulher, exatamente às 20 horas e 7 minutos, dessa noite. (Rede Globo, 31 de outubro de 2010).

6. Dilma Rousseff (PT) é a primeira mulher eleita presidente do Brasil. O presidente do TSE, Ricardo Lewandowski, reconheceu a vitória da petista na TV às 20h14 deste domingo, 31. (http://www. estadao.com.br, 31 de outubro de 2010).

7. Dilma Rousseff foi eleita neste domingo a mais nova presidente do Brasil. Primeira mulher a ocupar o cargo no país, a ex-ministra da Casa Civil obteve a preferência de 51 milhões de eleitores (http://veja.abril.com.br, 31 de outubro de 2010). 
8. Dilma Rousseff é eleita a primeira presidente da história brasileira (http:/ /www.eleicoes.uol.com.br, 31 de outubro de 2010).

9. Pela primeira vez na nossa história, uma mulher é eleita para a presidência da República (http://www.cartacapital.com.br, 31 de outubro de 2010).

10. Dilma Rousseff: Brasil elege $\mathbf{1}^{\mathrm{a}}$ presidenta (http://especiais. ig.com.br, 31 de outubro de 2010).

11. Dilma Rousseff, foi eleita neste domingo a $40^{\mathrm{a}}$ presidente da história do Brasil. Esta é a primeira vez que uma mulher ocupa o cargo no país (http://www.portugues.rfi.fr, 31 de outubro de 2010).

12. Dilma Rousseff (PT) está eleita presidente do Brasil (...) Ainda na juventude, logo depois do golpe militar de 1964, Dilma se interessou pelo socialismo. Foi militante de esquerda, integrou movimentos que pregavam o uso de armas contra o regime militar, como o Comando de Libertação Nacional (COLINA). Ficou presa de 1970 a 1972, condenada a seis anos de cadeia, primeiro na Oban, onde foi torturada e depois no DOPS (http:/ / sul21.com.br, 31 de outubro de 2010).

13. Dilma Rousseff (...) fue electa Presidente en los comicios de este domingo y se convertirá en la primera mujer en ostentar ese cargo. (...) Economista, de 62 años, Rousseff participó en la resistencia armada al régimen militar que gobernó Brasil entre 1964 y 1985, y por ello pasó tres años encarcelada; en el período que se siguió a su arresto fue sometida a torturas por sus captores (http://www.elpais.com.uy, 31 de outubro de 2010).

14. Rousseff es la primera presidenta mujer de Brasil (http:// www.pagina12.com.ar, 31 de outubro de 2010).

15. Dilma Rousseff [...] se convierte en la primera mujer que accederá a la Presidencia en Brasil, el país más grande de América Latina (www.clarin.com, 31 de outubro de 2010).

16. Dilma Rousseff, economista de 62 años que en su juventud conoció la guerrilla, la cárcel y la tortura, se convirtió el domingo en la primera mujer elegida para gobernar Brasil (www.emol.com, 31 de outubro de 2010). 
17. The result completed an unlikely journey for Rousseff that took her from jail and brutal torture by her military captors in the 1970s to become the first woman to lead Latin America's largest economy (New York Times, 31 de outubro de 2010).

18. A former Marxist rebel who was jailed and tortured during Brazil's military dictatorship last night became the first female president in her country's history. (http://www.guardian.co.uk, 31 de outubro de 2010).

19. Dilma Rousseff. Brazil's first female president (http://www. cbc.ca, 31 de outubro de 2010).

20. Dilma Rousseff has won the election for president in Brazil, according to the country's Supreme Electoral Tribunal Minister,making her the nation's first woman to hold the office ( http:/ /www.cubaheadlines.com, 31 de outubro de 2010).

21. Mme Rousseff, du Parti des travailleurs, devient la première femme à diriger le plus vaste pays d'Amérique du Sud et quatrième plus grande démocratie du monde (http://qc.news. yahoo.com, 31 de outubro de 2010).

22. Dilma Rousseff élue présidente du Brésil (http://www. forumfr.com, 31 de outubro de 2010).

23. La candidate du Parti des travailleurs, Dilma Roussef, est devenue dimanche la première femme présidente du Brésil em remportant le second tour de l'élection présidentielle avec plus de 55\% des suffrages (http://www.lepetitjournal.com, 31 de outubro de 2010).

A circulação/confronto dessas formulações, de um lado, indica que esse acontecimento é marcado pela sua atualidade (pela novidade que não tira sua opacidade) e pela memória, que é imediatamente convocada para funcionar; e de outro lado, marca discursivamente o acontecimento. As expressões destacadas em negrito nas formulações de 4 a 23 podem ser agrupadas em duas séries parafrásticas e polissêmicas: 
(b)

[...] pela primeira vez na história, o poder executivo do Brasil será comandado por uma mulher. Dilma está oficialmente eleita Presidente da República

Pela primeira vez, uma mulher é eleita presidente do Brasil. [...] O Brasil ganhou a sua primeira presidente mulher

Dilma Rousseff (PT) é a primeira mulher eleita presidente do Brasil.

Dilma Rousseff foi eleita neste domingo a mais nova presidente do Brasil.

Primeira mulher a ocupar o cargo no país

Dilma Rousseff é eleita a primeira presidente da história brasileira

Pela primeira vez na nossa história, uma mulher é eleita para a presidência da República

Dilma Rousseff: Brasil elege $1^{a}$ presidenta

Dilma Rousseff, foi eleita neste domingo a $40^{a}$ presidente da história do Brasil. [...] é a primeira vez que uma mulher ocupa o cargo no país

Dilma Rousseff (PT) está eleita presidente do Brasil

Dilma Rousseff [...] fue electa Presidente en los comicios de este domingo y se convertirá en la primera mujer en ostentar ese cargo.

Rousseff es la primera presidenta mujer de Brasil

Dilma Rousseff [...] se convierte en la primera mujer que accederá a la Presidencia en Brasil, el país más grande de América Latina

Dilma Rousseff se convirtió el domingo en la 
primera mujer elegida para gobernar Brasil

Dilma Rousseff. Brazil's first female president

Dilma Rousseff has won the election for president in Brazil

Mme Rousseff (...) devient la première femme à diriger le plus vaste pays d'Amérique du Sud et quatrième plus grande démocratie du monde

Dilma Rousseff élue présidente du Brésil

Dilma Rousseff est devenue dimanche la première femme présidente du Brésil

Analisando a série (b) na perspectiva de Pêcheux (1983), poderíamos dizer que o resultado apresentado pela mídia evoca o sentido logicamente estabilizado: no dia 31 de outubro de 2010 Dilma Rousseff foi eleita a primeira presidente do Brasil. A evidência do sentido é sustentada pela lógica apresentada: Dilma Rousseff derrotou seu adversário nas urnas e tornou-se a primeira presidente do Brasil. As formulações/reformulações apresentadas em (b), entretanto, são opacas. O efeito metafórico das expressões dessa série é resultado da tensão, do retorno ao mesmo no espaço do dizível, que é marcado pela paráfrase, e no espaço do diferente ou do deslocamento ou deslizamento de sentidos, que é marcado pela polissemia.

Desta forma, as formulações/reformulações colocadas em circulação/confronto na noite do dia 31 de outubro têm uma duração no presente, mas evoca o passado e o futuro. Quem foi eleito presidente do Brasil? A esquerda? O PT? Os partidos aliados? Essas perguntas desorganizam o sentido logicamente estabilizado evocado pela mídia e evocam outros sentidos, pois o acontecimento de 31 de outubro de 2010 é marcado pela atualidade 
e pela novidade: Dilma Rousseff é a primeira presidente do Brasil, mas, ou ao mesmo tempo, pela memória que é atravessada pela história de gerações de mulheres (índias, negras, brancas, ricas ou pobres, famosas ou anônimas, livres ou escravas) que, da Colônia à República, participaram de relacionamentos de forças, lutaram e promoveram contracondutas individuais e coletivas no interior de racionalidades políticas, para poderem se subjetivar no lugar de sujeito político. O nome Dilma Rousseff, neste sentido, deixa de figurar uma pessoa para figurar um lugar que representa todas as gerações de mulheres brasileiras (anônimas, esquecidas, pouco lembradas) que não aceitaram as injunções impostas pela sociedade e se colocaram no lugar de resistência.

Cumpre também ressaltar que na circulação-confronto de formulações sobre o acontecimento da noite de 31 de outubro de 2010 a mídia deslizou o sentido da participação de Dilma nos movimentos clandestinos, na militância contra o regime militar. Se antes do acontecimento da noite de 31 de outubro o sentido evocado era negativizado para impedir o acontecimento, depois dos resultados das urnas o mesmo fato passou a funcionar com estabilidade lógica variável. A interpretação política evocada mostrou que os sentidos se delineiam na relação que uma palavra ou expressão tem com outra palavra ou outra expressão e na relação que um acontecimento tem com outro acontecimento. Por isso a série parafrástica e polissêmica (b) é seguida da série (c):

c)

Foi militante de esquerda, integrou movimentos que pregavam o uso de armas contra o regime militar, como o Comando de Libertação Nacional (COLINA).

Ficou presa de 1970 a 1972, condenada 
a seis anos de cadeia, primeiro na Oban, onde foi torturada e depois no DOPS

Rousseff participó en la resistencia armada al régimen militar que gobernó Brasil entre

1964 y 1985, y por ello pasó tres años encarcelada; en el período que se siguió a su arresto fue sometida a torturas por sus captores

economista de 62 años que en su juventud conoció la guerrilla, la cárcel y la tortura

Rousseff that took her from jail and brutal torture by her military captors in the 1970s to become the first woman to lead Latin America's largest economy

A former Marxist rebel who was jailed and tortured during Brazil's military dictatorship last night became the first female president in her country's history.

Diferentemente da série (a), a série (c) aparece como comentário, como complemento da série (b), mas também como esclarecimento e acréscimo do que foi silenciado na série (a). Nas expressões das formulações/reformulações colocadas em circulação/confronto na noite de 31 de outubro de 2010, Dilma Rousseff, quando jovem, militou e integrou movimentos de resistência ao regime militar, foi presa e torturada, e aos 62 anos tornou-se a primeira presidente do Brasil. Nesse trabalho de memória, o sentido aparentemente estabilizado em que Dilma era apresentada pela mídiacomo subversiva e terrorista, deslizouse para o sentido em que Dilma Rousseff, a primeira mulher presidente do Brasil, é apresentada como mulher destemida, líder, de personalidade forte, de estilo polêmico e combativo, responsável e comprometida com o Brasil, requisitos que lhe permitiram chegar ao mais alto cargo do Poder Executivo, 
provocando ruptura tanto na história do País quanto na história das mulheres, que vêm conseguindo conquistar espaços na esfera pública e têm mostrado que podem se subjetivar em todas as esferas de poder político do país - no Executivo, no Legislativo e no Judiciário.

Do acontecimento de 31 de outubro de 2010 registramos o seguinte trecho do primeiro pronunciamento da primeira presidente do Brasil:

Esse fato, para além da minha pessoa, é uma demonstração do avanço democrático do nosso país, porque pela primeira vez uma mulher presidirá o Brasil. Já registro, portanto, o meu primeiro compromisso após a eleição: honrar as mulheres brasileiras para que esse fato até hoje inédito se transforme num evento natural e que ele possa se repetir e se ampliar nas empresas, nas instituições civis e nas entidades representativas de toda a nossa sociedade. A igualdade de oportunidade entre homens e mulheres é um princípio essencial da democracia.

Eu gostaria muito que os pais e as mães das meninas pudessem olhar hoje nos olhos delas e dizer: 'Sim, a mulher pode'. A minha alegria é ainda maior pelo fato que a presença de uma mulher na Presidência da República se dá pelo caminho sagrado do voto, da decisão democrática do eleitor, do exercício mais elevado da cidadania (ROUSSEFF, 2010 - grifos nossos).

\section{Considerações finais}

Diante do exposto, salientamos que somente por meio daquilo que está à margem e que está interdito é possível entendermos as estruturas sociais ou as regularidades de um campo social ou de uma racionalidade política qualquer. 
Tentamos mostrar que, no conjunto de relacionamentos de forças que produzem saber e inserem-se nos gestos, atitudes e discursos que permeiam nossa sociedade, gerações de mulheres, da Colônia à República, têm participado de ações e movimentos que se opunham às formas de condução das condutas no interior das racionalidades políticas.

$\mathrm{Na}$ materialidade discursiva das formulações postas em circulação na sociedade, os sentidos das formulações sobre mulher e política não são logicamente estabilizados, ou seja, são logicamente variáveis. Gerações de mulheres brasileiras, independentemente de raça ou classe social, subjetivaram-se no lugar de resistência, lutaram e lutam, promovendo, conforme as condições e possibilidades de cada época, contracondutas que dizem respeito a determinados modos e práticas de objetivação e de subjetivação de homens e mulheres na sociedade.

Dessa forma, as contracondutas que acontecem no interior de cada racionalidade política indicam que, ao lado do desenvolvimento de modos de objetivação que transformavam e transformam mulheres (e homens) em sujeitos/objetos dóceis e úteis, desenvolveram-se modos de subjetivação por meio dos quais ocorre a efetiva constituição e transformação da mulher como sujeito político, com identidade própria, possibilitando, entre outros fatos, o acontecimento de 31 de outubro de 2010, em que Dilma Rousseff foi eleita a primeira presidente do Brasil.

\section{Referências}

AVELAR, L. Mulher e Política: o mito da igualdade. Democracia Viva, n. 32, p. 98-102, jul./set 2002. 
BASTOS, N. de S.. Mulheres em armas: memória da militância feminina contra o regime militar brasileiro. 2004. Disponível em: <http://www.gedm.ifcs. ufrj.br/textos.php>. Acesso em: 22 dez. 2009.

BLAY, E. A. Um caminho ainda em construção, a igualdade de oportunidades para as mulheres. Revista USP, São Paulo, n. 49, p. 82-97, mar./mai. 2001.

DANIEL, T. T.; PEREIRA, R. RODRIGUES. O voto feminino no Brasil. Boletim Informativo da PRR/ $3^{a}$ Região, São Paulo, 06 de mar. 2009. Edição Especial. Disponível no site da PRR/3a Região: http://www.prr3.mpf.gov. $\mathrm{br} /$ index.php?option $=$ com_content $\&$ task $=$ view $\& i d=136 \&$ Itemid $=178$. Acessado em acesso em 29 de maio de 2009.

FONSECA-SILVA, M. da C. Poder-saber-ética nos discursos do cuidado de si e da sexualidade. Vitória da Conquista: Edições Uesb, 2007a.

Ethos, memória e cenas validadas da corrupção política em Veja.

In: III Simpósio Internacional sobre análise do discurso: emoções, ethos e argumentação, 2008, Belo Horizonte. Anais III Simpósio Internacional sobre análise do discurso: emoções, ethos e argumentação. Belo Horizonte: UFMG, 2008. p. 75-76.

FOUCAULT, M. Microfísica do poder. Rio de Janeiro: Graal, 1988. p. 145-53. Edição original: 1979.

- Ditos e escritos: estratégia, poder-saber. Vol. IV. Rio de Janeiro:

Forense Universitária, 2006.

ORLANDI, E. P. As formas do silêncio. Campinas: Editora da Unicamp, 1992.

PÊCHEUX, M. O discurso: estrutura ou acontecimento. Campinas: Pontes, 1997. Edição original: 1983.

PERRO'T, M.. As mulheres ou os silêncios da história. Bauru, SP: EDUSC, 2005.

VENTURA, Z. 1968: o ano que não terminou. Rio de Janeiro: nova Fronteira, 1988. 
DREYFUS, H. L.; RABINOW, P. Michel Foucault, uma trajetória filosófica: além do estruturalismo e da hermenêutica. Rio de Janeiro: Forense Universitária, 1995.

Deleuze, G. Foucault. Lisboa, Vegas, 1992.

RIDENTI, M. S. As mulheres na política brasileira: os anos de chumbo.

Tempo Social. Revista de Sociologia da USP, São Paulo, v.2, n.2, p. 113-128, 1990. 


\section{IDENTIDADES DO MASCULINO NO HUMOR}

Adélli Bortolon Bazza ${ }^{38}$, Maria Célia Cortez Passetti ${ }^{39}$

Os confrontos e disputas por espaço entre o gênero masculino e o gênero feminino parecem algo bastante comum e existente há muito tempo. Diferentes documentos, textos e figuras de diversas épocas oferecem-nos informações sobre a atribuição de papéis a cada gênero em determinada cultura, lugar e/ou tempo. Esses textos constituem discursos sobre o que é ser homem e o que é ser mulher, mostrando que essas relações foram e são tensas.

Ao relacionar esses discursos podemos perceber certas regularidades, como a recorrência de práticas que constituem discursos machistas, feministas, igualitários e outros; mas ocorrem também deslocamentos, possibilitando a irrupção de um novo discurso. Entre os recentes deslocamentos observados no campo do gênero destaca-se o surgimento do chamado "novo homem" identidade para o masculino. A chegada dessa nova identidade,

38 Doutoranda do Programa de Pós-Graduação em Letras da UEM.

39 Professora do Departamento de Letras e do Programa de Pós-Graduação em Letras da UEM.

40 Bonácio, neste volume, aprofunda a reflexão sobre as práticas e os discursos que contribuem para o surgimento dessa identidade de masculino. 
como qualquer mudança, trouxe incômodos, discussões e inquietações. Uma das grandes dificuldades estava em delimitar quais seriam os elementos, as práticas, as crenças que compunham essa identidade. Ao contrário da postura machista, com a qual as pessoas conviveram por muito tempo e da qual já havia se instaurado uma memória, o "novo homem" ainda tinha/tem sua identidade em construção.

A mídia tem contribuído bastante para a instauração da identidade desse "novo homem" ao fazer circular inúmeros textos abordando o assunto. Textos que parecem ser puramente informativos ou jocosos criam propostas de identidades para esse "novo homem" e as fazem atingir homens e mulheres. Neste artigo selecionamos como objeto de análise um texto produzido pela mídia televisiva, com o intuito de observar como as identidades de masculino são representadas e como se pode criar o humor a partir delas. Trata-se do programa "Sexo Frágil", exibido pela Rede Globo no ano de 2003, sob a forma de seriado humorístico. Algumas peculiaridades justificam a escolha desse programa, entre elas o fato de ser veiculado pela televisão, um dos mais difundidos meios de comunicação no Brasil, e a sua proposta de ridicularização dos homens ao retratá-los como sexo frágil.

\section{Criar, discutir e rir das identidades}

Falar desse "novo homem" compreendendo-o como uma identidade de masculino implica pensar o contexto para o surgimento dessa e de outras identidades. Apesar de este tema ser discutido há algum tempo, a identidade e assuntos a 
ela relacionados têm recebido acentuada atenção dentro das discussões, quando associada ao Pós-Modernismo e seus efeitos.

Teóricos filiados aos chamados Estudos Culturais têm apontado alguns dos sintomas dessa fase. O Pós-Modernismo implica o questionamento das verdades dadas a priori, a multiplicação e a simultaneidade de informações, eventos e ideias e a velocidade com que as coisas são criadas, mudadas ou descartadas, tudo isso culminando numa constante provisoriedade que atinge também as noções sobre o que é "ser" hoje.

Hall (1997) mostra as mudanças que contribuíram para o declínio da representação do sujeito moderno e a instauração de outro, o sujeito pós-moderno. De acordo com autor, há cinco grandes 'descentramentos' que incidem nesse sujeito cartesiano: 1)- o pensamento marxista, que compreende o sujeito como fruto de um contexto; 2)- a descoberta do inconsciente, a qual mostra que o sujeito não domina tudo que pensa e faz; 3)- a concepção de língua de Saussure, que recusou as escolhas individuais na fala ao considerar a língua um sistema negociado na sociedade; 4)- o sujeito de Foucault, que é fruto de uma dispersão de discursos; e 5)- o feminismo.

De acordo com o autor, o feminismo questionou a distinção entre dentro e fora, público e privado enfatizou a forma como somos constituídos como sujeitos, colocou em questionamento a concepção de homens e mulheres como parte de uma única identidade e propôs a questão da diferença sexual.

É a partir da tendência do pensamento feminista calcado na diferença que se desenvolve melhor esse pensamento e se chega à compreensão de que o 
“masculino" e o "feminino" são criações culturais e, como tal, são comportamentos apreendidos através do processo de socialização que condiciona diferentemente os sexos para cumprirem funções sociais específicas e diversas. Essa aprendizagem é um processo social. Aprendemos a ser homens e mulheres e aceitar como "naturais" as relações de poder entre os sexos (ALVES; PITANGUY, 1985, p. 55).

É a partir dessa perspectiva que se começa a questionar os conceitos de homem e de mulher e também os de masculino e o feminino. Desde o momento em que esses conceitos começam a ser pensados como fruto de um processo que se dá no e pelo meio social, passa-se a trabalhar com o conceito de gênero.

Reflexões dessa natureza desencadearam a reestruturação das identidades, culminando, entre outras propostas, na de identidade para o "novo homem". Esse não é um processo tão simples assim, pois, ao mesmo tempo em que há grupos ávidos por mudanças, há também bastante resistência. Destarte a discussão se apresenta de forma sutil, e muitos textos que abordam essa temática se caracterizam por certa leveza, certa graça, que muitas vezes é obtida através do humor. Essa relação também não parece ser fortuita...

É notória a frequência com que no humor se abordam temas controversos. Parece haver uma moratória social que permite que por meio do humor se trate de temas e/ou se assumam posicionamentos socialmente polêmicos sem que as pessoas sejam punidas pelos gracejos que produzem. Isso possibilita que em nossa sociedade o humor se constitua como um lugar de contestação de valores sem que quem dele participe sofra alguma sanção. Possenti (2000, p. 82) formula essa ideia ao afirmar que "rimos da subversão dos valores". Diante disso, pareceu-nos interessante observar a discussão sobre a reestruturação das 
identidades dos gêneros, especificamente da do "novo homem", em um texto de natureza humorística.

Saliba (2002) considera que o humorismo seria uma reflexão que transforma aquilo que nos é familiar, que poderia ter acontecido conosco em algo estranho a nós. Esse estranhamento do humor possibilita-lhe o caráter desmistificador, mas o leva a um território de fragmentação e mudanças, ou seja, aquilo que se produz em humor não se repete ad infinitum, pelo contrário, tende a caducar logo, pois os alvos do humor são seres históricos, produzidos socialmente portanto, igualmente mutáveis.

Em função desse caráter sócio-histórico do humor, algumas questões são motivadas pela ocorrência do programa Sexo Frágil: o fato de ter sido possível fazer humor acerca de um novo (ou velho?) tipo de homem pode indicar que a representação da identidade de masculino tradicional como única e homogênea já foi atingida por essas reconfigurações pós-modernas e que estamos, no mínimo, diante de duas possibilidades de identidade de masculino: o velho (forte?) e o novo (frágil?). Essas possibilidades se multiplicam quando se leva em conta o fato de as identidades não serem homogêneas, estanques e acabadas, mas heterogêneas, interligadas e sempre negociadas.

A observação de alguns recursos causadores do efeito humorístico pode ajudar a compreender os movimentos de identificação e desidentificação criados nesse discurso. A primeira questão envolve as implicações sociais do riso, que Bergson (1983) considera como uma espécie de correção social da rigider mecânica dos sujeitos. É como se a situação requeresse determinada habilidade e flexibilidade que ela não teve e de cuja falta se risse. 
Nessa perspectiva, o riso é confirmado como uma forma de castigar os costumes, pois, assim como as coisas mudam,

a sociedade há de querer um esforço constante de adaptação recíproca [dos indivíduos]. Toda rigidez do caráter, do espírito e mesmo do corpo, será, pois, suspeita à sociedade [...]. Ela está diante de algo que a inquieta, mas a título de sintomas apenas - simplesmente ameaça, no máximo um gesto. E, portanto, por um simples gesto ela reagirá. $\mathrm{O}$ riso deve ser algo desse gênero: uma espécie de gesto social (BERGSON, 1983, p. 19).

No caso de Sexo Frágil, a rigidez é um dos motes desencadeadores do riso no programa. Apresentadas com o objetivo de ridicularizar o homem, as situações cômicas vividas por esses quatro rapazes devem-se à inadequação desses personagens às diversas situações vividas por eles na sociedade atual, principalmente no que toca às suas relações com as mulheres ou com áreas em que a mudança promovida pela revolução feminista requeira adaptações.

Outro mecanismo de criação do humor presente no programa é a paródia. Descrevendo-a à esteira do dialogismo bakthiniano, Sant'Anna (2002) a considera um texto polifônico, porque nele se podem perceber várias vožes. Não obstante, o autor (SANT'ANNA, 2002, p. 14) ressalta que "as vozes na paródia não são apenas distintas e emitidas de uma para outra, mas se colocam, de igual modo, antagonisticamente". Esse antagonismo, por um lado, evidencia a oposição entre masculino e feminino, ressaltando a polêmica instaurada entre os diferentes posicionamentos; e por outro, descentra e, assim, destrona, ridiculariza a pretensa identidade una e homogênea do sujeito masculino. 
Terceira parte :: Identidades do masculino no humor

\section{Analisar as identidades discursivas}

Devido à heterogeneidade que atravessa a discurso e, consequentemente as identidades nele produzidas, torna-se difícil descrever uma identidade de masculino assumida pelos personagens do programa. Descrever essa identidade é, em última instância, descrever o processo de identificação do(s) sujeito(s) analisado(s) com as demais identidades, com os demais discursos, com as memórias que cada um deles atualiza.

Dessa maneira, a análise inscreve-se no campo discursivo a partir do conceito de 'identidade de posicionamento'. Isso quer dizer que pretendemos discutir a identidade a partir da "posição que o sujeito ocupa em um campo discursivo em relação aos sistemas de valores que aí circulam" (CHARAUDEAU; MAINGUENEAU, 2004, p. 267). Para tanto, buscaremos a identidade do sujeito masculino representada no programa Sexo Frágil pela rede de relações discursivas estabelecida entre sujeitos masculinos e femininos desse programa, tentando identificar a posição-sujeito que esses homens assumem ou que lhe é delegada na prática discursiva humorística.

Pensar essa rede de relações discursivas implica abordar a heterogeneidade que constitui os sujeitos (personagens do programa) e os discursos que eles suportam. Muitas vezes, em casos de citações e de discursos diretos e discursos indiretos, a presença do discurso Outro é marcada como constituinte do que Authier-Revuz (1982) denominou heterogeneidade mostrada 'marcada', embora haja momentos em que essa cisão entre o discurso Mesmo e o Outro não é tão evidente, como no caso do humor, em que um "outro dizer" é retomado para produzir sentido, mas não necessariamente é explicitado. 
Dessa forma, para compreender os sentidos produzidos nesse programa seria necessário identificar a hetegoneidade mostrada 'não marcada'. Para tanto valeu-nos a noção de interincompreensão polêmica de Maingueneau (2007), que oferece suporte para analisarmos a heterogeneidade discursiva também no Mesmo.

A constituição de um discurso implica uma relaçãointrínseca com o seu Outro, pois o Outro "É o que faz sistematicamente falta a um discurso e lhe permite fechar-se em um todo. É aquela parte de sentido que foi necessário que o discurso sacrificasse para construir sua identidade”. (MAINGUENEAU, 2007, p. 39). No caso do discurso masculino, há sempre um outro, o feminino, que é constitutivo dele e que é sacrificado para que o primeiro constitua sua identidade; mas esse discurso Outro não é apagado do discurso Mesmo, mas entra na constituição deste.

Para pensar a relação de um discurso com seu Outro, Maingueneau (2007, p. 22) formula a hipótese de que "o caráter constitutivo da relação interdiscursiva faz aparecer a interação semântica entre os discursos como um processo de tradução, de interincompreensão regrada". Dessa forma, reconheceríamos, em um enunciado, traços do seu discurso mesmo e do seu discurso 'outro', ainda que não estivéssemos diante de um caso de heterogeneidade mostrada. Dentro do campo discursivo que trata da relação entre os gêneros, podemos pensar esse efeito ao opor um discurso machista tradicional e um discurso feminista, considerado mais moderno. Cada um deles está constituído sobre um sistema semântico particular que o coloca em confronto e, consequentemente, não lhe permite compreender o outro.

$\mathrm{O}$ enunciador e o seu discurso não conseguem lidar diretamente com o Outro, eles traduzem esse outro dentro de 
seu sistema de valores, criando dele 'simulacros'. É por isso que Maingueneau (2007, p. 103) afirma que

\footnotetext{
esses enunciados do Outro só são "compreendidos" no interior do fechamento semântico do intérprete; para constituir e preservar sua identidade no espaço discursivo, o discurso não pode haver-se com o Outro como tal, mas somente com o simulacro que constrói dele.
}

Por estarem em concorrência dentro do campo discursivo, esses discursos polemizam entre si, trabalhando na incessante tentativa de estabelecer sua identidade a partir da nega(tiviza) ção do seu Outro. Para o Maingueneau (2007, p. 110), "'manter a própria identidade e definir a priori todas as figuras que o Outro pode assumir são uma e só coisa". A identidade de masculino criada a partir da Formação Discursiva (FD) machista se constrói com a noção de oposição: assim como estão opostos semas positivados e negativados, opõem-se os gêneros (masculino e feminino). A identidade então se fecha por conta da identificação de si aos semas positivos e pela impossibilidade de seu outro (sujeito feminino) e Outro (discurso feminino) se identificarem a esses semas positivos.

Pretendemos analisar os traços/semas que constituem o sujeito masculino do programa Sexo Frágil, tratando a polêmica com o discurso feminino como fator de desestabilização, descentramento e criação de humor sobre esse sujeito e sua identidade; ou seja, queremos apreender, como propõe Maingueneau, a rede de relações interdiscursivas na qual esse discurso se constitui. Por tratarmos da oposição entre os gêneros, oporemos a FD machista à FD igualitária, pois, principalmente nos últimos anos, o feminismo tem proposto a igualdade entre os gêneros, em contraposição à ideia radical de superioridade de 
um sobre o outro. Esse ideal de convivência parece-nos ter se configurado como o verdadeiro ${ }^{41}$ dessa época.

\section{A identidade do "novo homem" em questão}

Para analisar quais identidades foram construídas para o masculino nesse programa, selecionamos uma cena em que os amigos, reunidos em um bar, relatam problemas que vêm enfrentando em seu dia a dia como resultado da convivência com as mulheres e buscam definir um lugar para si mesmos nessa cadeia de eventos ${ }^{42}$. Esta cena faz parte do nono programa, intitulado "Para que serve um homem?". Nela interagem os personagens Edu, representado por Vagner Moura, e Alex, representado por Bruno Garcia. Posteriormente, a Edu e Alex se juntam Fred, representado por Lázaro Ramos, e Beto, representado por Lucio Mauro Filho.

Nesse programa Alex trabalha em uma fábrica de lingerie e está concorrendo a uma vaga de gerente geral da empresa, mas perde a vaga para uma colega de trabalho. Edu chega a sua casa de uma viagem trazendo flores para a esposa, Malu, e a encontra na cama com outra. Fred, que é jornalista, perde uma reportagem

41 Empregamos esse termo a partir da noção foucaultiana de que uma série de discursos apresenta um mesmo saber e esse se estabelece como verdade para um grupo e em um momento determinado. Cf. Foucault (1999).

42 A cena analisada neste artigo faz parte do corpus de nossa dissertação de mestrado. Por isso, muitas das asserções aqui levantadas estão fundamentadas em observações das demais cenas analisadas durante a pesquisa. Para uma compreensão mais ampla do tema, cf. BAZZA, A. B. Identidade(s) do sujeito masculino no programa humorístico Sexo Frágil. 2009. 112 f. Dissertação de Mestrado (Mestrado em Letras) Centro de Ciências Humanas Letras e Artes. Universidade Estadual de Maringá, Maringá, 2009. 
para uma colega de trabalho e ainda apanha dela. Beto, que está separado de Vilminha, não consegue realizar consertos em encanamentos do apartamento para agradar e tentar reconquistar a mulher.

No original do programa esta cena era bastante extensa. Para adaptá-la e adaptar sua análise a este texto, foi suprimido um trecho de seu meio. Trata-se do momento em que Beto e Fred chegam ao bar e contam seus problemas. Essa supressão os comentários sobre a cena são marcados dentro do quadro de transcrição por letra em itálico.

Trilha sonora
Bar onde seria a festa de Alex, decorado com bexigas
e faixas com dizeres "Alex o chefe do ano". Alex,
sozinho, bebe e fuma. Edu chega
Cantor canta música: Eu não sou cachorro não,
pra viver tão humilhado, eu não sou cachorro
não, para ser tão desprezado.
Edu: Alex, uma desgraça aconteceu.
Alex: Minha promoção no trabalho dançou.
Edu: Então foram duas.
Alex: Você perdeu a promoção também?
Edu: Não, não, não. Foram duas desgraças.
(senta-se) Eu perdi a Malu.
Alex: Só? Eu perdi a gerência inteira.
Edu: Promoveram outro?
Alex: Pior, promoveram outra. Eu vou ter uma


Edu: Mas essas mulheres tão tomando conta de tudo, gente.

Alex: A Malu também te trocou por outro?

Edu: Pior, por outra.

Alex: Que isso?

Edu: E o nome da pessoa é Ricardinha. Agora nós estamos competindo pra ver quem vai ficar com a Malu.

Alex: E o que é que você tá fazendo aqui? Quer acabar perdendo a Malu por WO?

Edu: Não, eu pensei em te pedir umas dicas, assim... sobre a superioridade dos homens em relação às mulheres, mas eu acho que não foi uma boa ideia.

Beto e Fred também chegam e desabafam sobre seus problemas.

Edu: A verdade é uma só, gente: nós somos o chamado sexo frágil.

Alex: Elas estão no poder.

Beto: No comando.

Fred: Os números comprovam: as mulheres vivem $30 \%$ a mais que os homens.

Edu: Elas odeiam rachar a conta do restaurante. Alex: Elas adoram ir ao banheiro em turma.

Beto: Elas se depilam com o nosso aparelho de barbear.

Fred: Pior: elas fingem orgasmo.
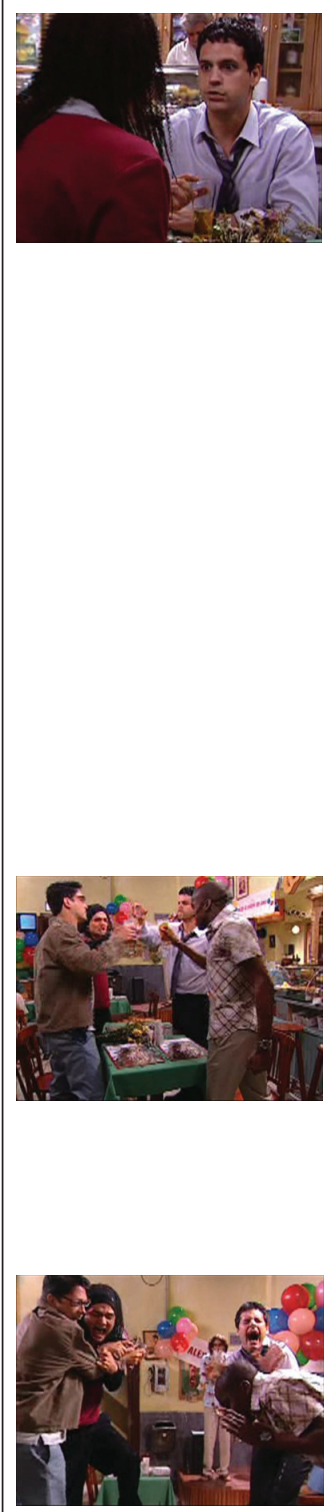
Edu: Fingem orgasmo.

Alex: Fingem orgasmo.

Beto: Quase sempre fingem orgasmo.

Alex: Tá cada vez mais difícil fazer uma mulher feliz.

Música: E o nosso amor, pelo amor de Deus, eu não sou cachorro não.

Edu: A gente tem valor.

Edu: Eu vou mostrar pra Ricardinha que os homens são muito superiores às mulheres. A Malu será minha! Minha!

Beto: A Vilminha não vai acreditar de tanta privada que eu vou desentupir, de tanta lâmpada que eu vou trocar.

Alex: Eu vou provar pra minha chefe que eu sou melhor que ela. No final ela vai acabar me promovendo a chefe dela mesma.

Fred: É!!!!

Os quatro: Viva os homens!!!!!!

(Barulho de tiro, todos gritam e sobem nas cadeiras, apavorados).

Havia sido combinada uma festa no bar para comemorar o aniversário de Alex. Essa cena inicia-se com Alex sentado sozinho à mesa. Edu chega ao bar desesperado, pois acabara de flagrar sua mulher com outra, fato que ele denomina "uma desgraça", indicando a importância que ele dá ao que aconteceu. Alex, sem saber dos problemas pessoais do amigo, desabafa, dizendo a Edu que sua promoção no trabalho não acontecera. 
A fala de Alex minimiza o problema de Edu, ao dizer: "Só? Eu perdi a gerência inteira". Isso demonstra a valorização do trabalho em oposição aos problemas sentimentais. Mais que um possível egoísmo de Alex, localiza-se aí uma identificação ao discurso machista, retomando-se o ideal de masculinidade atrelado ao racional, em oposição à consideração do sentimento como um campo feminino.

Com isso Alex identifica-se à FD machista, mas sua identidade de macho está descentrada pelos fatos vividos pelo personagem: a promoção de uma mulher em seu lugar. A natureza humorística desse discurso é um dos fatores que permitem que o personagem Alex identifique-se a um discurso tão tipicamente machista, pois o discurso que predomina atualmente na sociedade é o da igualdade.

Como toda identidade se marca pela afirmação do eu simultaneamente à negação do outro, e ao mesmo tempo associa o racionalismo à identidade de homem macho que cria, Alex denega o discurso sentimental e a preocupação com o relacionamento, que, segundo seu sistema de valores, caracteriza seu par oposto na vida (a mulher) e o discurso com o qual ele polemiza, o feminismo. A primeira identidade de homem delineada e assumida no discurso da cena é a do homem machista, que apresenta um discurso ainda bastante característico, mas é descentrado pelos fatos de seu dia a dia e confrontado com a necessidade de nova(s) identidade(s).

$\mathrm{Na}$ realidade, o que preocupa Edu é o que ele sente no âmbito do seu relacionamento amoroso com Malu. Com isso ele assimila à sua identidade o sentimentalismo que Alex denega para delimitar a dele, e juntamente com ela, surgem traços de identificação com a FD machista. 
Ao perguntar se promoveram 'outro', Edu verbaliza a pressuposição de que o chefe seria um sujeito do sexo masculino, discurso que se atrela ao ideal de masculinidade comentado acima, o qual, por representar o homem como o gênero racional, descreve o trabalho como um de seus domínios pela suposta necessidade de racionalidade para desempenhá-lo.

Ao afirmar que as mulheres estão tomando conta de tudo, Edu demonstra ter constituído sua fala a partir da FD machista que tem um dos gêneros (o masculino) como o responsável, o que "toma conta" das coisas; entretanto esse discurso 'mesmo' está perturbado pelo simulacro de seu Outro, pois no simulacro as mulheres estão assumindo o papel que 'cabe aos homens'.

Em seguida Alex pergunta a Edu se a Malu o trocou por 'outro', manifestando, assim, uma visão da sexualidade vivida apenas na heterossexualidade. Ele nem cogita a hipótese de uma relação homossexual, ou seja, a FD machista silencia constitutivamente a igualdade entre os gêneros, assim como a homossexualidade. Edu confirma esse posicionamento do amigo ao afirmar "pior, por outra"; ou seja, é difícil ser traído, mas para Edu isso é ainda pior, pois ocorreu a partir de uma relação homossexual. Reitera ainda este ideal a reação de Alex, que até então, olhando para seu copo, aparentemente dá pouca importância ao caso do amigo. Alex põe as mãos na mesa, dá um salto na cadeira e encara o amigo arregalando os olhos, mostrando bastante espanto pelo fato de Malu estar com outra mulher.

Na sequência da narrativa, Edu relata que ele e a 'outra' estão competindo para ver quem fica com a Malu. Nesse momento tem-se mais um ponto de descentramento desse sujeito masculino identificado à FD machista. De acordo com Oliveira (2004), a tenacidade, a força e a potência necessárias à prática esportiva 
são valores que se agregaram ao ideal moderno de masculinidade. Por mais que sejam deslocados pelos acontecimentos recentes, esses sujeitos ainda são atravessados por discursos oriundos de uma FD machista, mas apesar disso, esse homem (machista) vem descentrado pelo fato de ter como adversária uma mulher.

O fato de a amante de sua esposa se chamar Ricardinha também produz diferentes efeitos de sentido se considerada a historicidade desse termo: "Ricardão" tornou-se sinônimo de amante. A cena sugerida nesse programa foi semelhante: Edu chega de viagem e pega sua mulher na cama com outra, lugar comum ao "Ricardão" agora desempenhado por uma mulher. O relacionamento entre Malu e Ricardinha é sugerido como o estereótipo clássico de traição heterossexual. Até o nome da moça faz alusão ao do homem, quando nesse lugar: Ricardinha é o nome que designa essa mulher, mas, por associação a Ricardão, torna-se o nome genérico que pode se referir a qualquer amante do sexo feminino. A diferença aqui está na inversão do uso do sufixo: enquanto para o gênero masculino usa-se o aumentativo, para designar o gênero feminino usa-se o diminutivo, forma descrita como típica da variedade linguística do gênero feminino.

Alex repreende o amigo por estar ali no bar e questiona: “Quer perder a Malu por W.O.?" Essa discussão sobre a disputa amorosa é atravessada por termos próprios a um jogo, a uma competição esportiva. Edu afirma que ele e Ricardinha estão 'competindo' para ver quem fica com a Malu. Esse efeito de sentido culmina na representação de um estereótipo de homem machista ao confrontar a competitividade e racionalidade necessárias à prática esportiva (lidas pelo sujeito colocado numa FD machista) e a sensibilidade esperada pelas mulheres na relação amorosa (tradução que o discurso do 'senso comum' faz do discurso feminino). Dessa forma, tem-se a heterogeneidade 
do discurso presente no mesmo desse discurso e essa presença faz deslocar o sentido das memórias retomadas, produzindo o antagonismo próprio ao humor.

Com isso, delineia-se a segunda identidade de masculino dessa cena: enquanto Alex fala da FD machista com traços quase clichês de representação do seu discurso característico, Edu também é interpelado por essa FD; mas sua identidade também é constituída por traços do simulacro que a FD machista cria do feminino. Esse sujeito torna-se risível pelo antagonismo que essas vozes apresentam e pelo fato de ainda estar perdido.

Depois de relatados os problemas particulares que cada personagem vive nesse episódio, os quatro amigos começam a tecer considerações acerca das relações entre os gêneros. Ao dizer: "A verdade é que nós somos o chamado sexo frágil", Edu retoma o discurso de que a mulher é o sexo frágil, mas inverte essa relação. Tem-se aqui uma memória que é retomada, mas vem deslocada, como efeito da "tradução" feita pelo discurso machista da proposta de igualdade do discurso feminino e também como causa de humor. Agora são os homens que se identificam ao adjetivo frágil e à posição de sujeito que ele confere. Para o falante posicionado na FD machista, as melhores posições são propriedade do homem, portanto, qualquer tentativa de modificar esse estado de coisas desencadeia uma "revolução". O simulacro que esses homens criam do discurso feminino é sempre o estereótipo da feminista radical que visa a dominá-lo, e, consequentemente, a identidade que lhe caberia é a de homem inferiorizado.

Para reiterar essa posição os personagens citam dados que parecem seguir uma escala: vão do mais sério/científico ao mais chão/cotidiano. Por exemplo, "os números 
comprovam, as mulheres vivem $30 \%$ a mais que os homens" (científico), "elas odeiam rachar a conta" (cotidiano), "elas se depilam com nosso aparelho de barbear (cotidiano íntimo), "elas fingem orgasmos" (ápice da intimidade). Essas inserções de argumentos oriundos de diversos campos da convivência vão dando a amplitude desse fenômeno e contribuindo para o efeito humorístico do quadro. Tem-se aqui o destronamento tão caro à paródia: vozes/discursos se misturam, antagonizam-se e se ridicularizam.

Nesse caso, o destronamento ocorre em dois níveis: no primeiro, são ridicularizadas as relações estabelecidas entre os gêneros, ao serem mostradas em situações que se opõem; em seguida os sujeitos se identificam a esse cenário, afirmando: "Tá cada vez mais difícil fazer uma mulher feliz". Assim eles se colocam na posição-sujeito oferecida pela FD machista, que vê o macho como provedor, assumindo a função tradicional de satisfazer uma mulher; porém esse discurso mostra-se inadequado às situações vividas por eles. Tem-se, então, um sujeito que, colocado em lugar discursivo, verbaliza essa posição nos discursos que profere, mas se depara com uma conjuntura diferente, constituída sob uma nova ótica - calcada em discursos oriundos de outra FD: a da igualdade entre os gêneros.

Essa FD não pode ser compreendida tal como o é pelos sujeitos posicionados na FD machista. Eles a 'traduzem' como aquela que propõe a superioridade feminina e a inferioridade masculina. Novamente se está falando da interincompreensão polêmica dos discursos que possibilita a presença do discurso 'outro', o igualitário, no 'mesmo' machista que tenta circunscrevê-lo para delimitar sua identidade. 
O destronamento desse sujeito machista e sua identificação à posição-sujeito de sexo frágil são reiterados pela música de fundo: "Eu não sou cachorro, não", de Valdick Soriano.

Após esse momento os rapazes iniciam uma reação. Num ímpeto de coragem, Edu dá um murro na mesa, afirma que os homens têm valor e que pretende mostrar a superioridade masculina reconquistando Malu. O clima contagia: Beto se propõe a realizar com presteza as tarefas de manutenção da casa e Alex decide ser melhor que sua chefe no trabalho. Contagiados por esse espírito de revanche/superação, eles dão um viva aos homens.

Comessaatitude,poder-se-iaacreditarnumadesidentificação desses sujeitos com a posição-sujeito de inferiorizados que haviam assumido anteriormente e num movimento de retorno e identificação com um ideal clássico machista de masculinidade. Nesse caso, novamente se incorporariam a esses sujeitos os valores de bravura e coragem. Essa imagem é logo ridicularizada, pois eles ouvem barulho de tiro e todos eles gritam, sobem nas cadeiras, apavorados e tremem a ponto de derramar a cerveja dos copos.

Apesar do rompante de valentia no discurso verbal, as atitudes desses homens correspondem à representação do feminino como sexo frágil quando traduzido pelo discurso machista. Subir na cadeira gritando é um típico clichê da mulher frágil e medrosa que se assusta com baratas. Ironicamente, essa postura é assumida pelos sujeitos masculinos, que haviam acabado de se propor a mostrar às mulheres a superioridade e o valor dos homens. É interessante que o simulacro da igualdade, traduzido como "superioridade feminina" pelo discurso machista, exerce a 
função de inverter os papéis, passando o dominado a ser dominador, e vice-versa.

\section{Considerações finais}

A observação do discurso do/sobre o masculino nessa cena mostra que os sujeitos masculinos no discurso do programa são constituídos a partir de sua identificação com a FD machista. Eles colocam a superioridade e o domínio como características intrínsecas ao masculino e tentam desqualificar seu outro, o discurso da igualdade, negando-o. $\mathrm{O}$ funcionamento discursivo leva o sujeito a assumir um posicionamento e essa identificação impede o sujeito de compreender seu discurso outro tal como ele se constitui, possibilitando-lhe apenas criar um simulacro dele. Os indivíduos do programa criam um simulacro desse outro, leem-no como uma proposta de inversão dos papéis: o homem, de dominador da mulher, passa a ser dominado por ela.

Essa atribuição segue a ordem vigente pela visão machista: há um gênero que domina o outro, mas agora as posições são invertidas: o gênero dominante é o feminino e o dominado é o masculino. Essa inversão mostra, ao mesmo tempo, a criação de uma identidade de homem machista e a necessidade de o sujeito se desligar dessa identidade para conviver na sociedade atual. Isso torna esses personagens e suas identidades risíveis, e no discurso do programa encontra-se um 'velho homem' destronado, subvertido ou um novo homem ainda perdido, que não sabe como agir. É nesse contexto que o homem se vê como inferiorizado, - portanto, como o sexo frágil. 


\section{Referências}

AUTHIER-REVUZ, J. Hétérogeneité montrée et hétérogeneité constitutive: éléments pour une approche de láutre dans lê discours. In $D R L A V$ - Revue de linguistique, n. 26, Paris, 1982.

ALVES, B. M.; PITANGUY, J. O que é feminismo. São Paulo: Brasiliense, 1985. BERGSON, H. O Riso. Tradução de Nathanael C. Caixeiro. 3. ed. Rio de Janeiro: Zahar, 1983.

CHARAUDEAU, P.; MAINGUENEAU, D. Dicionário de Análise do Discurso. São Paulo: Contexto, 2004.

FOUCAULT, Michel. Microfísica do poder. Rio de Janeiro: Graal, 1999.

HALL, S. A identidade cultural na pós-modernidade. Tradução: Tomaz Tadeu Silva e Guacira Lopes Louro. Rio de Janeiro: DP\&A, 1997.

MAINGUENEAU, D. Gênese dos discursos. Curitiba: Criar, 2007.

OLIVEIRA, P. P. A construção social da masculinidade. Belo Horizonte: Editora UFMG; Rio de Janeiro: IUPERJ, 2004.

POSSENTI, S. Os Humores da língua. Campinas: Mercado de Letras, 2000.

SALIBA, E. T. Raízes do riso - a representação bumorística na bistória brasileira: da Belle Époque aos primeiros tempos do rádio. São Paulo: Companhia das Letras, 2002.

SANT'ANA, A. R. de. Paródia, paráfrase \& cia. São Paulo, Ática, 2002. 



\section{REPRESENTAÇÕES DA MASCULINIDADE EM CRISE:}

LEGADOS PÓS-MODERNOS

Daiany Bonácio ${ }^{43}$

\section{Considerações iniciais}

O momento atual é de mudanças, de transformações. Novas maneiras de pensar e de agir configuram a sociedade, que está deixando de lado os valores tidos como imutáveis e fixos para ceder espaço a uma sociedade em constantes mudanças. $\mathrm{O}$ sociólogo Bauman $(2003 ; 2007)$ assinala que estamos vivendo em uma sociedade líquida.

Nesse cenário social emerge um sujeito que também acompanha tais mudanças. Valores tradicionais, concebidos como organizadores e norteadores da sociedade - a razão, Deus, as ciências, a família, o trabalho, o Estado - neste momento estão sendo substituídos por valores nem sempre fixos e muitas vezes descartáveis. Para Santos (s.d.), cada coisa estava em seu lugar, representada com clareza e organização, mas

Para representar as coisas com clareza precisamos organizar e para organizar precisamos de identidades fixas e definidas, que permitam separar isto daquilo: preto ou branco, rico ou pobre, real ou

43 Doutoranda do Programa de Pós-Graduação em Linguística da UFSCar. 
imaginário. A representação clara, ordenada, funciona na base do OU, que é separação e exclusão. Até a Modernidade, trabalhou-se assim: era-se capitalista ou socialista, normal ou louco, culto ou analfabeto (SANTOS, s.d, p.109).

Com a chegada da Pós-Modernidade, essa garantia já não é mais tão segura. Esse sentimento de insegurança, essa fugacidade e diversidade, são refletidos nos sujeitos e, consequentemente, em suas identidades.

O chamado Pós-Modernismo é um momento histórico que tem possibilitado várias mudanças na sociedade e tem como uma de suas consequências o crescimento do mercado capitalista, que a cada dia aumenta sua versatilidade, visando a angariar clientes ao mesmo tempo em que os deixa cada vez mais insatisfeitos. A busca incessante por ampliar mercados faz com que esse fato resvale nas identidades, já que cria nos sujeitos desejos de obter, de consumir, de ter, em função do lucro e da ampliação de mercados. Ademais, tal momento histórico propõe a derrubada das certezas universais, o que culmina em transformações no modo de ser e de viver dos sujeitos.

Nesse âmbito, surgem discursos que produzem sentidos para formar o que a mídia brasileira contemporânea vem chamando de "novo homem". Tais discursos desconstroem a "velha" imagem masculina de indivíduo forte e machista. Como superfície de emergência para práticas discursivas identitárias, muitos dos enunciados produzidos pelos meios de comunicação acerca dessa temática apregoam para o homem uma nova identidade, pautada em um sujeito moderno. Os elementos discursivos que concorrem para isso empregam estratégias linguísticas e imagéticas altamente excludentes e idealizadas. Neste trabalho propomo-nos a analisar semelhantes questões, levando em consideração o fato de teóricos culturais como 
Hall (1997), Bauman (1998; 1999a; 1999b; 2007) e Santos (s.d) problematizarem a chamada "crise de identidade". No tocante às questões de gênero, essa crise se manifestaria na inversão de papéis, no enfraquecimento de identidades sólidas, como, por exemplo, a postura tradicional masculina.

\section{Um novo tempo}

A expressão Pós-Modernismo, em consonância com Santos (s.d.), é utilizada para marcar o encerramento do Modernismo (1900-1950) e as mudanças ocorridas na segunda metade do século XX, em que ocorreram transformações no campo das ciências, das artes, da história, do pensamento, da comunicação, configurando novas maneiras de pensar a sociedade, assim como uma nova forma de cultura e pensamento, o que vem levando ao declínio os valores e as grandes instituições clássicas. Ao derrubar as certezas universais em vigor até então, a cultura pós-moderna abalou as bases do mundo e dos indivíduos. No lugar das bases sólidas e unas dos tempos anteriores surge o Pós-Modernismo, constituindo um momento eclético, plural, em que há mistura de diferentes estilos. Bauman (2003) nomeia esse novo período de 'sociedade líquida'. Para esse autor, a Pós-Modernidade é a Modernidade sem ilusões, pois,

Diferentemente da sociedade moderna anterior, a que eu chamo de Modernidade sólida, que também estava sempre a desmontar a realidade herdada, a de agora não o faz com uma perspectiva de longa duração, com a intenção de torná-la melhor e novamente sólida. Tudo está agora sempre a ser permanentemente desmontado, mas sem perspectiva de nenhuma permanência. Tudo é temporário. É por isso que sugeri a metáfora de "liquidez" para caracterizar o estado 
da sociedade moderna, que, como os líquidos, se caracteriza por uma incapacidade de manter a forma. Nossas instituições, quadros de referência, estilos de vida, crenças e convicções mudam antes que tenham tempo de se solidificar em costumes, hábitos e verdades "auto-evidentes". É verdade que a vida moderna foi desde o início "desenraizadora" e "derretia os sólidos e profanava os sagrados", como os jovens Marx e Engels notaram. Mas, enquanto no passado isso se fazia para ser novamente "reenraizado", agora as coisas todas empregos, relacionamentos, know-hows etc. — tendem a permanecer em fluxo, voláteis, desreguladas, flexíveis (BAUMAN, 2003, p. 5-6).

Ainda segundo Bauman (1998), a Pós-Modernidade se caracteriza pela mobilidade, pelo fato de tudo estar em movimento. Esse "estar em movimento", na perspectiva do autor, nem sempre acontece espontaneamente, pois muitas vezes é marcado por ações aleatórias, dispersas, em busca de direção, a fim de se fixar. O problema que essa sociedade líquida tem de enfrentar é que ela sempre se depara com curvas e com frustrações. A 'vida líquida' de que trata Bauman $(2003 ; 2007)$ em seus livros é uma vida efêmera, que logo perde a sedução em detrimento de outras atrações. Neste sentido, não há como fixar hábitos, criar raízes, como era feito em outros tempos. Em paralelo a essa efemeridade está o receio de não acompanhar a fluidez da vida, a velocidade dos acontecimentos, dos produtos, enfim, de ficar para trás neste mundo pós-moderno. O autor adverte também que, caso o ser humano não busque a Modernidade, ele poderá perecer, já que o sistema capitalista atual gera no indivíduo um sentimento de sentir-se dividido na necessidade de se adequar à sociedade e o medo de ficar defasado, de não conseguir acompanhar as mudanças.

A vida moderna ume motivo de orgulho para o ser humano, porque ele se sente livre, é plural, híbrido; no entanto, os prazeres e as sensações da vida moderna também trazem sofrimentos, submissões, crises, incertezas, evidenciando que esse ganho 
também acarreta perdas. Bauman (1998, p. 156) chama a atenção para o fato de que "os mal-estares, aflições e ansiedades típicos do mundo pós-moderno - resultam do gênero de sociedade que oferece cada vez mais liberdade individual ao preço de cada vez menos segurança”. O homem está "livre" para escolher, mas essa certeza nada lhe garante, nada de fato lhe assegura. Essa liberdade traz certos perigos, porque a condição pós-moderna divide os sujeitos: há uma porção que se sente feliz por estar seduzida e atendida pelo mercado, e outra parte que se sente infeliz por estar oprimida por esse mesmo mercado. Assim, há uma parte da sociedade que celebra o pós-moderno e uma que sofre suas consequências, como as misérias, as incertezas, as crises.

As transformações das identidades dos sujeitos na sociedade pós-moderna se devem, em muitos aspectos, ao mercado capitalista. Atualmente a pretensa felicidade está na posse de determinados objetos de desejo, tais como carros, casas, bens de consumo em geral; em ter um estilo de vida moderno e luxuoso e um corpo bonito. Enfim, a felicidade encontra-se em consumir. Essa mensagem, em conformidade com Bauman (1998), vem de todos os lugares e pelos mais diversos veículos de comunicação. Não há como os sujeitos "fugirem" das propagandas que os induzem ao consumo sem limites. Bauman (2007) assevera que a sociedade de consumo contemporânea atua de modo a oferecer aos sujeitos uma satisfação tão intensa que jamais alguma sociedade foi capaz de oferecer satisfação semelhante. O problema, para o autor, é que essa satisfação nunca acaba: para o mercado continuar lucrando, promete satisfazer os indivíduos, mas logo em seguida lança outros produtos, ocasionando a insatisfação, e o desejo de consumo, por sua vez, se agrava. O autor exemplifica que o método usado é "satisfazer toda necessidade/desejo/vontade de uma forma que não pode 
deixar de provocar novas necessidades/desejos/vontades. O que começa com necessidade deve terminar como compulsão ou vício" (BAUMAN, 2007, p. 106).

Além das mudanças supracitadas que abrangem ambos os gêneros, a identidade masculina também foi profundamente influenciada pelas alterações sofridas pela identidade feminina. As discussões de Ghilardi-Lucena (2003) nos levam a perceber que a mulher há muito tempo foi associada à fraqueza, à vaidade, à docilidade, sendo submetida às forças da tradição. Era criada para ser dócil, obediente e submissa. Nas diferentes sociedades e em diferentes tempos a mulher sempre foi vista como mãe, esposa, dona de casa, conselheira. Por outro lado, já na Antiguidade as figuras femininas buscavam romper com essas forças, como forma de fuga desse estereótipo. Apesar de tantas lutas, a mulher sempre esbarrava em obstáculos, porque essas questões apareciam na construção da história como se fossem próprias da natureza dos sexos. Confortlin (2003) aponta que ser homem ou mulher tem mais influências sociais do que naturais. Obviamente, existem as características biológicas de cada ser, as quais estão ancoradas no aspecto social; mas a articulação do biológico com o social permite uma espécie de naturalização do social, o que pôde ser encontrado durante muitos anos nos livros, na escola, em casa, na cultura popular. Afirmava-se que a mulher era mais sensível, mais afetiva, mais frágil, sentimental e intuitiva, haja vista o fato de seu cérebro ser desenvolvido diferentemente do masculino, o que tornaria o homem supostamente mais racional nas decisões a serem tomadas e mais apto para lidar com as áreas do saber relacionadas às ciências exatas.

Essa associação do biológico com o social possibilitou a emergência de discursos que dividem os sujeitos conforme as características femininas e masculinas ancoradas em imagens 
sólidas de identidades de gêneros. Esses discursos produzidos socialmente eram reproduzidos por diversas e significativas instâncias sociais, como a família, a Igreja, a escola e a religião. Ser mulher era tido como algo adquirido no momento do nascimento, e não como uma questão socialmente construída pelas várias influências recebidas pelo sujeito mulher durante sua vida. Simone de Beauvoir, em seu livro O Segundo Sexo (1949), compreendeu bem essa questão quando pronunciou sua célebre frase: "Não se nasce mulher, torna-se mulher".

Essas atribuições sociais a homens e mulheres foram mantidas durante séculos, mas só começaram a entrar em discussão mais fervorosa com os movimentos feministas em meados do século XX, quando as mulheres começaram a lutar pela igualdade entre os sexos. No campo profissional, por exemplo, a dominação masculina começou a ser abalada, deixando de ser algo evidente para se tornar discutível e posto em xeque. Prova disso é o desempenho das mulheres em setores tradicionalmente masculinos.

Ademais, essas mudanças não pararam no campo profissional, também se estenderam para ao campo familiar:

À medida que a mulher entrou para o domínio público, levou sua visão e seus valores para a política, para o esporte, para o trabalho, o homem viu-se obrigado a ingressar no domínio do privado, sendo parceiro nas atividades familiares, sobretudo na educação dos filhos.

Essas mudanças trouxeram profundas consequências: em primeiro lugar, desmontou as articulações sociais e milenares de sociedade de classes e cultura patriarcal, conceito passado através de gerações. Isto porque a mulher não estava integrada no sistema produtivo que as estruturas de dominação puderam vigiar. A partir do seu ingresso no sistema produtivo, houve a mudança na família. A criança já não vê mais o pai mandando e a mãe obedecendo, mas sim dois centros de poder diferentes atuando com igual dignidade (CONFORTLIN, 2003, p. 117). 
A derrubada de tabus por parte das mulheres e seu ingresso no domínio público provocaram transformações para ambos os sexos, tanto nos campos social, político e econômico quanto no pensamento.

Como vimos, o poder masculino é uma construção histórica, e não uma determinação biológica, como se acreditava. Houve uma desnaturalização dessas construções, fortemente evidenciada pelos movimentos sociais da década de 1960, nos quais esses sentidos pré-construídos foram deslocados, permitindo que as identidades começassem a entrar no que Hall (1997) denomina crise, em razão de os sujeitos terem perdido suas referências simbólicas, que atualmente são contestadas e não funcionam mais como lugares simbólicos de identificação.

O feminismo agiu tanto como crítica teórica quanto como um movimento social. Hall (1997) expõe que o feminismo questionou muitos conceitos, como a família, a sexualidade, o trabalho doméstico e a sua divisão, incluindo o cuidado com os filhos. Esses movimentos sociais contribuíram para o descentramento do sujeito do Iluminismo, que era tido como um indivíduo de identidade fixa e estável, e tiveram uma importância decisiva na constituição das identidades contraditórias e fragmentadas que começam a ser percebidas no sujeito pósmoderno.

O Pós-Modernismo foi propulsor das lutas das mulheres por seus direitos, pois com a derrubada dos valores clássicos e universais os sujeitos começaram a criticar e a refletir sobre suas identidades e seus papéis sociais. A esse respeito, Giddens (1991 apud SGARBIEIRI, 2003 - tradução dessa autora) afirma: 
A tradição é um meio de lidar com o tempo e o espaço inserindo qualquer atividade ou experiência particular na continuidade do passado, presente e futuro, os quais, por sua vez, são estruturados por práticas sociais recorrentes.

$\mathrm{Na}$ Modernidade há certa desilusão com esses ideais, e a sociedade, que antes era estática e reprodutora, passa a ser dinâmica e questionadora. As mulheres inseridas nesse novo cenário também vão agir da mesma forma, buscando "despetrificar" os valores. O homem, nesse panorama, embora não tenha proposto nenhuma revolução, é atingido pela revolução que as mulheres realizaram a partir de meados do século XX.

Assim, diante das conquistas femininas, o sujeito masculino é chamado a se posicionar, mas, ao perder sua identidade sólida, ele sente-se perdido. Exemplo disto é o fato de muitos homens já não conseguirem prover sozinhos a casa, necessitando do auxílio feminino. Destarte, a crescente conquista das mulheres, iniciada nas décadas de 1960/1970, transformou as relações sociais entre homens e mulheres. O que notamos hoje, principalmente pelas lentes da mídia, é o surgimento de práticas discursivas identitárias que procuram construir uma nova imagem masculina a partir da desconstrução da imagem tradicional de homem provedor do lar e machista. Tais discursos operam de modo a produzir imagens positivas e negativas a respeito do homem.

\section{Mídia e identidade}

Gregolin (2003a), ao discorrer sobre os meios de comunicação, afirma que a mídia torna os fatos um espetáculo, 
algo que inúmeras vezes é comentado, falado, discutido. Com esse poder, a mídia transforma certos acontecimentos em espetáculos, convertendo em verdade a versão e a interpretação por ela apresentada. Assim sendo, o discurso que circula na mídia, na visão da autora, produz a cultura do espetáculo. Tal produção se dá no/pelo discurso, sendo campo produtivo para analisar o controle midiático. Vários são os setores da sociedade espetacularizados pelos meios de comunicação, como a política, a língua, a história, o corpo, o sujeito, a identidade e outros. Para Gregolin (2003a), se por um lado a quantidade de informações trouxe benefícios para os sujeitos - como qualidade de vida e desenvolvimentos técnicos -, por outro trouxe também alienação, com certos mecanismos e táticas que desenvolve para tornar os fatos e produtos verdadeiros atrativos "vitais".

O que se vê na média em termos de produção de identidades e de sua espetacularização é um tema sobre o qual os analistas do discurso estão se debruçando. Os estudos consultados indicam que a mídia emprega recursos linguísticos e visuais na produção de identidades para os sujeitos. Curcino-Ferreira (2007) afirma que, para controlar os sujeitos e suas identidades, a mídia se vale da individualização discursiva, uma maneira de se dirigir ao espectador de forma direta, produzindo efeitos de intimidade pelo uso de certos pronomes de tratamento. Ao agir de tal modo, a mídia individualiza para universalizar, haja vista que o indivíduo, ao sentir-se único, é levado a consumir tal produto, tal regime de emagrecimento, por exemplo, pois pensa que foi feito "única e exclusivamente" para ele. Além dos recursos linguísticos, o uso de imagens em que há um lugar vago para o espectador também tem esse efeito. Quebram-se as barreiras da distância e da objetividade para construir a necessidade e o desejo 
insaciável de ter algo. Para a autora, com esses mecanismos são criados os processos de construção de identidades: "É com base na consideração da individualização discursiva, empreendida pela mídia por meio de recursos diversos e responsável, entre outros efeitos, por instaurar processos de identificação" (CURCINOFERREIRA, 2007, p. 68).

A mídia faz circular representações, e para tal, na acepção de Gregolin (2007), articula os enunciados com a memória, forjando regras sociais para construir novas identidades, como, por exemplo, o discurso do corpo saudável, que atravessa diferentes campos de saberes, buscando subjetivar e formar identidades para os indivíduos. Ainda segundo Gregolin (2007), tais identidades funcionam como etiquetas e disciplinamento do corpo social; mas para os sujeitos tomarem isso para si, é preciso que seja algo agradável, por isso a mídia espetaculariza o corpo, mostrando-o belo, saudável, como uma verdadeira atração.

Ao descrever os poderes midiáticos que agem nos sujeitos e produzem identidades, a autora observa que não há apenas a passividade desses em receber tais poderes, há também momentos de fuga e de resistência por parte dos sujeitos:

A subjetividade é fabricada e modelada no registro social, mas os indivíduos vivem essa subjetividade tensivamente, reapropriando-se dos componentes fabricados e produzindo formas de individualização, criando outras maneiras de ser. Se só houvesse submissão, não haveria necessidade de reiteração. Acontece que não há agenciamento completo das subjetividades pelo poder: há um permanente entrelaçamento móvel entre as forças de territorialização e as desterritolização, ambas agindo e provocando contradições. Como consequência desses movimentos, as identidades não são rígidas nem acabadas (GREGOLIN, 2007, p. 55). 
Dessa forma, a autora enuncia que há um movimento contínuo de identificação, contraidentificação e desidentificação, o que revelaria não haver um regime de identidade estável. Como consequência, é sempre necessário inovar as formas de identidade, pois no momento histórico atual os sujeitos tendem a ficar insatisfeitos, com desejos efêmeros, necessitando sempre de novidades. Nesse movimento os indivíduos continuam consumindo as identidades propostas pela mídia, pois

O imaginário é guiado e canalizado na máquina de comunicação, e assim se legitima uma nova ordem mundial. A máquina comunicacional é auto-validante; é um dispositivo econômico-industrial-comunicativo que, ao mesmo tempo, engendra e legitima a biopolítica globalizada (GREGOLIN, 2007, p. 57).

A mídia se mostra detentora do saber quando, por meio do poder que detém, produz discursos que induzem os sujeitos ao desejo de realizar determinada tarefa ou de iniciar uma dieta milagrosa que os ajude a perder peso. Por essa análise, a mídia pretende representar uma dada coletividade que está à procura disso. Ela empenha-se em criar efeitos de verdade, e, como os sujeitos são movidos pela vontade de verdade (FOUCAULT, 1998), acabam acreditando no que a mídia propõe.

Em consonância com Gregolin (2003b), a mídia. Quando cria símbolos que alimentam o imaginário social, modela as condutas e os estilos de vida. Os sujeitos tomam esses fatos como verdades e os internalizam, uma vez que quem legitima as significações são as instituições reconhecidas socialmente e confiáveis, como a medicina. A autora afirma que a sociedade midiática atual está obcecada pelo espetáculo forjado, sendo guiada por valores efêmeros, de modo que estamos vivendo 
na sociedade do espetáculo, em que tudo é posto como show. Por outro lado, acrescenta a autora que, embora haja o poder e o controle, nenhum poder é total e absoluto - pelo contrário, é transitório e circular; por conseguinte, o poder está sempre se transformando e se reorganizando na busca de novas técnicas, porque ele é mutável, transferível. Além disso, tal poder não é exercido pela forma da repressão, mas, pela forma da sedução, realizando certas associações que legitimam os sentidos. Comungando dessa compreensão, Fonseca-Silva (2007) apresenta exemplos que comprovam tais associações, evidenciando que a mídia, na maioria das vezes, relaciona campos que despertam os desejos dos sujeitos, como, por exemplo, mulher e cerveja. Tais domínios são associados porque ambos são objeto de desejo de muitos homens e geram prazer.

Observa-se, assim, que a mídia possui mecanismos e estratégias para utilizar na produção de identidades, na espetacularização dos acontecimentos, na produção dos sentidos e no exercício do poder que produzem sentidos diversos, resultantes de sua prática discursiva. A mídia, além de sua função original de transmitir informação e entretenimento, possui grande poder sobre as atitudes e os discursos dos sujeitos. Se os meios de comunicação conseguem tal feito, conseguem-no porque detêm uma imagem positiva e de confiança aos olhos dos indivíduos. Com efeito, de transmissora de informações a mídia passou a ser formadora de opiniões, ao agir em favor das instituições que a financiam. A sociedade, nesse movimento, ao acreditar no que os meios de comunicação veiculam, permite-lhes o exercício do poder. 


\section{A identidade masculina na mídia}

A identidade masculina que atualmente vemos circular na mídia está sendo construída a partir da propagação de um novo homem. Tal sujeito não figura com o mesmo sentido de outras épocas, nas quais imperava determinada postura tradicional, machista e patriarcal. Os efeitos de sentido produzidos pela mídia para a construção identitária masculina muitas vezes se baseiam na retomada da memória sobre o que é ser homem, mas isto é realizado com o intuito de provocar deslocamentos e legitimar os discursos que constroem esse novo indivíduo.

Diante de tais transformações, surgem discursos diversos e heterogêneos que propõem "novas" identidades para o homem. Em vista disso, essas "novas" identidades emergem com a ação de práticas discursivas - medicina estética, mercado de trabalho, etc. - que empregam estratégias de identificação para os homens legitimadas pelo saber e poder que detêm. Em outras palavras, a identidade masculina atual é um efeito de sentido produzido pelas práticas discursivas interessadas em divulgar esse novo homem. Esse efeito, por sua vez, decorre de estratégias linguísticas e imagéticas empregadas pelo discurso midiático na produção de formas de identificação. As ações midiáticas disciplinam os corpos e a maneira de ser e pensar, à procura de certos objetivos, como o lucro Para esses objetivos da mídia serem alcançados é preciso que as mensagens tragam efeitos de verdades. De fato, os meios de comunicação procuram construir o verdadeiro de uma época e, para isso constroem certa imagem de identidade masculina que pode aceita por eles. Por esse motivo os sujeitos que não se enquadram nesse "novo" perfil não são ali representados, 
e o discurso exclui certas identidades e inclui outras, e é nesse momento que podem se manifestar as crises da identidade masculina.

Em nossa procura por enunciados midiáticos que tratem da identidade desse novo homem, percebemos certa recorrência de discursos que o comparam com a mulher. Nessa comparação, o homem é relegado a uma posição inferior. Para discutir essa questão selecionamos a abertura de um programa televisivo que constrói sobre o homem a imagem de um ser humilhado e submisso diante das mulheres e de suas conquistas.

O programa ao qual nos referimos é a série humorística exibida entre os anos de 2003 e 2004 pela Rede Globo de Televisão, denominado Sexo Frágil. Tal programa era exibido uma vez por semana e tinha como elenco apenas homens que encenavam papéis femininos, vestiam-se e se comportavam no cotidiano de modo semelhante às mulheres e ficavam desorientados diante de mulheres independentes e modernas.

A abertura serve de amostra para verificarmos como o enunciado constrói sentidos sobre o homem pós-moderno e as identidades por ele criadas. Comecemos com a descrição do plano linguístico, que é constituído por uma música:

Dizem que a mulher é a parte fraca, isso é que eu não posso acreditar, entre beijos e abraços e carinhos o homem não tendo é bem capaz de roubar.

Gosto que me enrosco de ouvir dizer que a parte mais fraca é a mulher e o homem com toda fortaleza desce da nobreza e faz o que ela quer. (Gosto que me enrosco - Sinhô) 
Junto com essa vinheta de abertura do programa Sexo Frágil são exibidas imagens de um homem praticando esportes. A edificação do sentido se dá conforme são arquitetados os planos ${ }^{44}$. Durante toda a abertura, basicamente as cenas são construídas de uma mesma maneira. Pirimeiramente é mostrado um homem forte praticando diferentes exercícios físicos. Nesse momento as cenas mostradas estão em tomada fechada, em plano americano ${ }^{45}$. Em um segundo momento, as cenas são abertas e mostra-se um plano de conjunto ${ }^{46}$. Tal plano nos permite ver com detalhes que o sujeito mostrado sempre pratica os esportes usando objetos femininos, como pó facial, escova feminina, brinco, rímel. Quando o primeiro plano é trazido, o homem é mostrado como alguém forte, musculoso, o que remete à ideia tradicional de homem viril; mas no momento da abertura dos planos se observa alguém inferiorizado e obrigado a submeter-se às mulheres. Abaixo, trazemos dois exemplos ${ }^{47}$ da exposição feita na abertura do programa em questão.

44 O plano é a distância da câmera em relação ao objeto filmado. Essa nomenclatura faz parte dos termos técnicos do cinema. Para realizar essa análise, visitamos o site: http://www. scribd.com/doc/507436/A-LINGUAGEM-DO-CINEMA-Reeditado, acessado em 04 de setembro de 2008.

45 Plano americano é o plano que "corta" a figura humana à altura dos joelhos.

46 No plano de conjunto, a área de ação de um filme é extensa e cheia de detalhes. Ela permite maior clareza aos pormenores da ação.

47 Como não obtivemos a liberação dos direitos autorais da abertura do programa, decidimos trazer uma releitura feita por João Pedro Oliveira Marques, que emprestou seu talento para resolver esse impasse. Para ter acesso à vinheta de abertura do programa, visitamos o site: http://www.youtube.com/watch?v $=$ yYauqTeQ2rc\&feature= related - acesso em $10 / 08 / 2010$ 

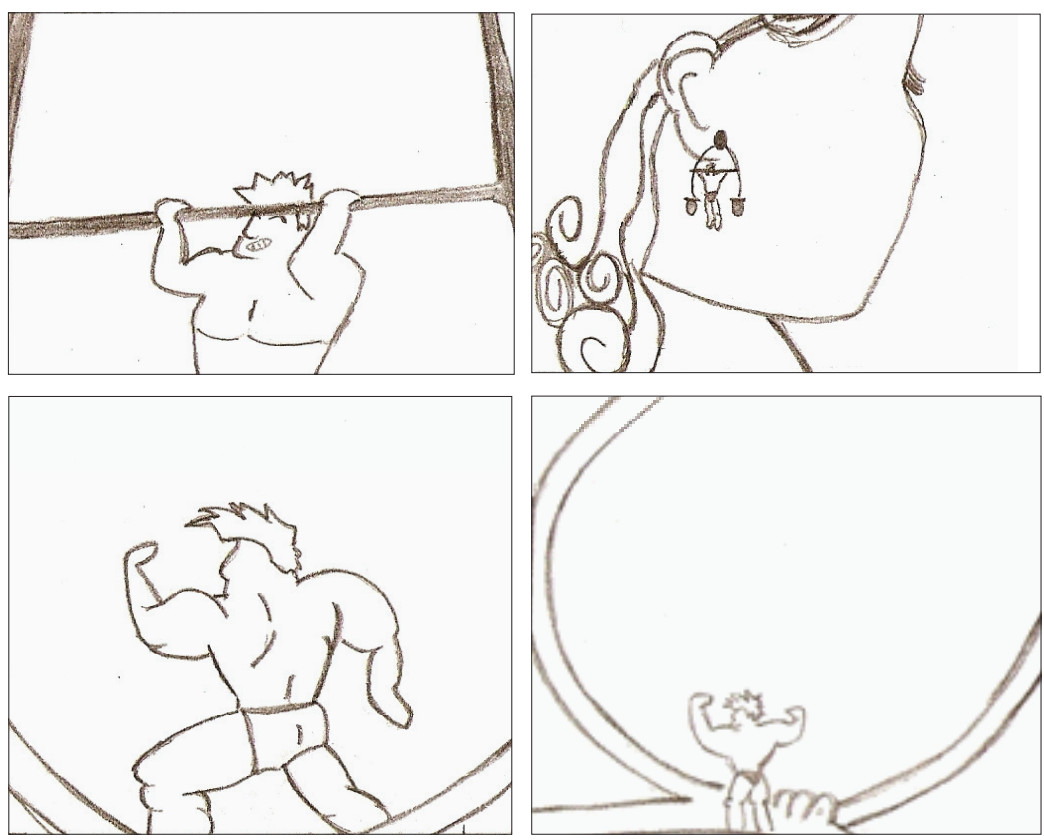

Figura 1 - Sequências de recorte da abertura do programa Sexo Frágil Fonte: Google Images.

Essa breve descrição possibilita interpretar os sentidos da abertura desse programa. Comecemos pelo plano linguístico. Os enunciados que compõem a música de abertura tornam evidentes algumas assertivas dessa canção. O início da música de abertura, que entoa: "dizem que a mulher é a parte fraca [...]", retoma os discursos que consideravam a mulher o sexo frágil, por ela ser, do ponto de vista biológico, supostamente mais fraca. $\mathrm{O}$ enunciado nega outro sentido de mulher, construído a partir dos anos 1960. Conforme Alves e Pitanguy (1981, p. 54), a partir dessa década,

o feminismo incorpora portanto outras frentes de luta pois, além das reivindicações voltadas para a desigualdade no exercício de direitos - políticos, trabalhistas, civis -, questiona também as raízes culturais 
mística de um 'eterno feminino' ou seja, a crença na inferioridade 'natural' da mulher, calcada em fatores biológicos.

Sabemos que, em determinados discursos, como os que circulam em gêneros do tipo piada e em conversas de botequim, a mulher sempre foi tratada de forma inferior, submissa e indefesa. O sujeito desse enunciado veiculado na canção de abertura do programa Sexo Frágil nos permite afirmar que ele, ao dizer o que diz sobre o homem pós-moderno, insere-se em uma formação discursiva segundo a qual os homens, na atualidade, são tão frágeis quanto as mulheres. Logo, o homem também pode ser considerado o sexo frágil: "frágil por carinhos", de acordo com o que apregoa a canção. Há nisso uma oposição, pois se a mulher é o sexo frágil, o homem é, paradoxalmente, o sexo forte. Tal ideia é comprovada com a palavra 'fortaleza' presente no sétimo verso. Essa memória, ao se inscrever na materialidade discursiva em análise, desloca sentidos, uma vez que, se antes os homens eram considerados o sexo forte, hoje em dia, como entoa a canção, eles descem da nobreza, isto é, da posição superior, e fazem o que as mulheres lhes pedem.

No nível imagético, essa oposição sexo frágil X sexo forte é construída por meio do funcionamento discursivo dos planos supracitados. Como pudemos verificar, no início da abertura do programa televisivo o predomínio do plano de conjunto contribui para a afirmação da imagem de virilidade vinculada ao universo masculino, imagem que é reafirmada pela repetição do ideal de homem forte, que se exercita, mostra sua força física, sua resistência. Por outro lado, quando a câmera se volta para o plano geral, o que se mostra é um homem viril que encontra sua força em objetos femininos. Neste sentido, quem aparece como sexo frágil não são as mulheres, às quais o senso comum confere esse atributo, mas os homens 
Os enunciados da canção articulam elementos discursivos da memória social acerca do chamado sexo frágil para provocar um deslocamento de sentidos, ao construírem a imagem do homem assumindo essa fragilidade e sendo submisso às mulheres. A mídia, então, vale-se dessa estratégia linguística e imagética para desconstruir a imagem de sexo forte vinculada ao universo masculino.

Quanto à posição de sujeito assumida pelo enunciador e à posição de sujeito "novo homem" construída nesse enunciado de abertura do programa Sexo Frágil, consideramos que os produtores dessa vinheta de abertura, comprometidos com o formato do programa, expõem os conflitos e as incertezas masculinas diante de mulheres independentes e fortes. Ao fazerem isso, representam esse "novo homem" em tempo de crise de identidade, como alguém inferior e à mercê dos mandos e desmandos das mulheres.

Fica evidente nesses enunciados que, ao se libertar da visão pré-construída de rainha do lar, de submissão às figuras masculinas autoritárias de pai e marido, a mulher deixa de ser considerada o sexo frágil e passa a ser vista como forte e batalhadora. Esse fato nos leva a considerar que nessa produção discursiva está escrita outra história: a das mulheres. Com efeito, essa nova maneira de discursivizar o homem comprova a presença de elementos discursivos que significavam o sexo feminino. É nesse movimento do sujeito (e dos sentidos) na história que começam a surgir esses "novos" discursos sobre o homem, já que certos conceitos que recobriam tarefas, obrigações e direitos relativos ao homem e à mulher vêm sofrendo descontinuidades e rupturas na História. O homem, por sua vez, também é atingido, pois dele se existem mudanças, haja vista que os discursos sobre o que é pertencer ao sexo masculino na mídia desconstroem no homem a imagem de 
machista e provedor do lar para mostrá-lo de outras maneiras. A prática discursiva midiática, guiada pelo poder do mercado, produz a imagem identitária de um sujeito humilhado e de uma mulher elevada. Entre o enaltecimento de um e a diminuição de outro, a mídia vai tecendo a história sobre a disputa entre os gêneros travada inicialmente no campo profissional.

A materialidade selecionada evidencia que o sujeito masculino, na sociedade pós-moderna, começa a somar preocupações; e com a privação de suas estabilidades tradicionais ele fica angustiado, em busca de equilíbrio ante tantas novidades. Vejamos essa realidade com o exemplo divulgado na coluna retirada da Revista Playboy: 


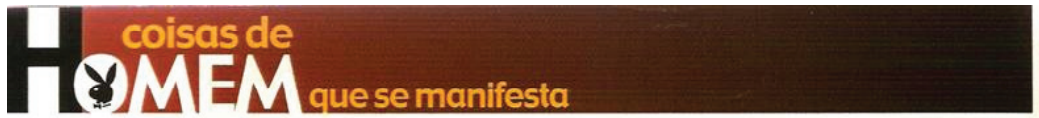

Por Miguel PAIVA
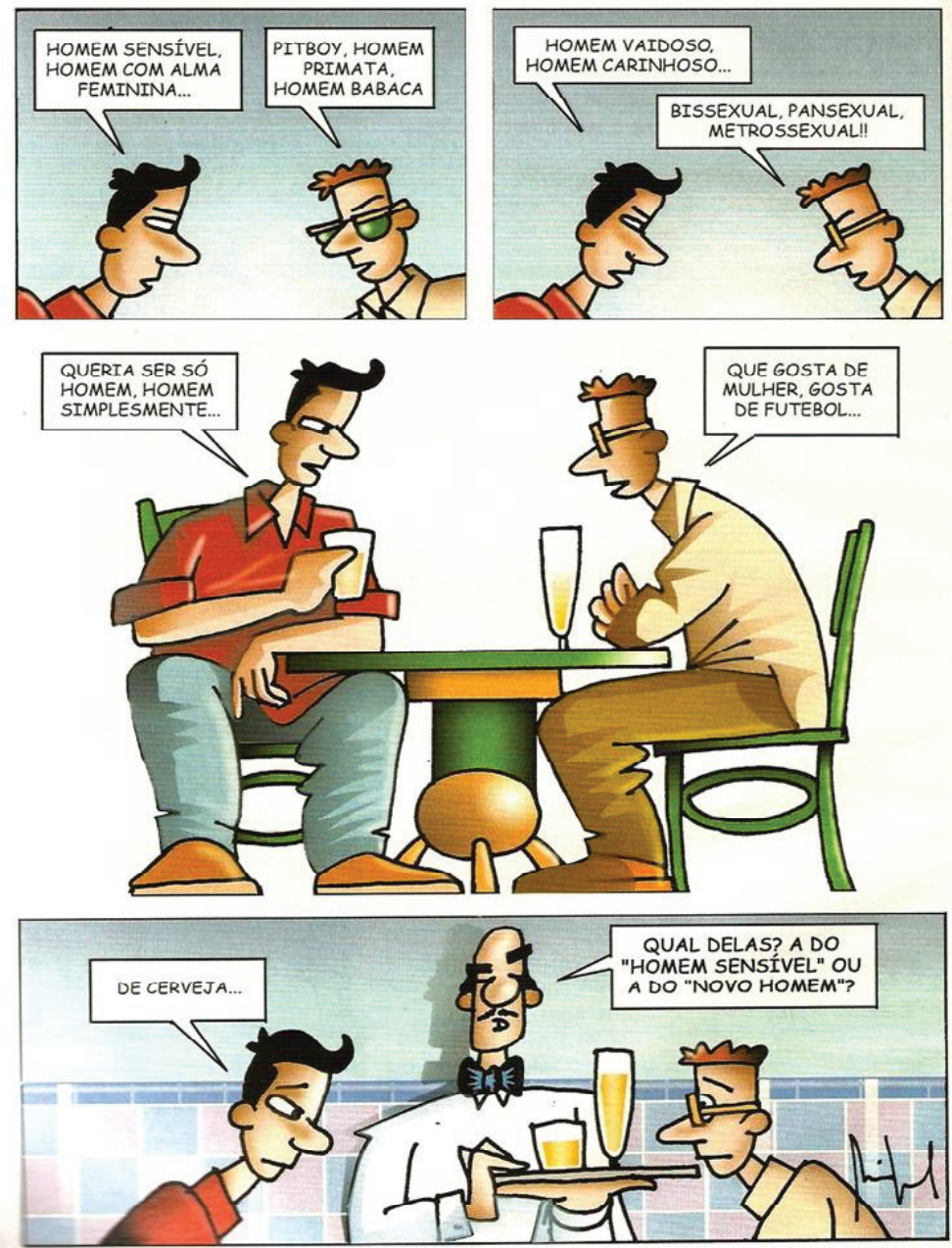

Figura 2 - Retirada da Revista Playboy, outubro de 2004, p. 24.

Fonte: Imagem gentilmente cedida pelo cartunista Miguel Paiva, pela Editora Abril e pela Playboy Brasil. 
O diálogo entre os dois sujeitos masculinos é bastante expressivo em relação à pluralidade de identidades encontrada na contemporaneidade para os homens: homem sensível, homem com alma feminina, pitboy $^{48}$, homem primata $^{49}$, homem babaca ${ }^{50}$, homem vaidoso ${ }^{51}$, homem carinhoso ${ }^{52}$, bissexual ${ }^{53}$, pansexual $^{54}$, metrossexual ${ }^{55}$. O diálogo remonta aos discursos que circulam em gêneros do tipo piada ou em conversas de botequim, os quais constroem o perfil de um homem que aprecia cerveja, mulher e futebol. Além disso, esses sujeitos frequentam um ambiente que, segundo os elementos discursivos da memória social, é tipicamente masculino: o bar. Ademais, com a intevenão do garçom na conversa nem isso existe mais, pois a cerveja, símbolo bastante emblemático do sujeito masculino, também tem variações: a do homem sensível ou do novo homem.

48 Pitboy é um tipo de homem que fica grande tempo em academias criando músculos para ficar forte. Além disso, ele pratica lutas como jiu-jitsu. Normalmente é nascido em família de classe social elevada e gosta de provocar brigas apenas para se divertir. O nome é derivado da mistura de um cão feroz da raça pitbull com boy, garoto em inglês.

49 O terno primata é usado para definir o homem em termos biológicos (A espécie humana chamada Homo sapiens está na ordem Primates, na qual estão os micos, macacos, gorilas, chimpanzés, dentre outras espécies bípedes).

50 Homem babaca é um sujeito que pratica tolices, sem inteligência ou sem juízo.

51 Homem vaidoso é alguém que gosta de cuidar de seu visual, se preocupa com a aparência física.

52 O sintagma homem carinhoso pode remeter ao homem meigo, afetuoso, delicado, um homem com sentimentos.

53 O bissexual é um comportamento sexual cuja característica é a atração por indivíduos tanto do sexo masculino quanto feminino.

54 O pansexual é um comportamento sexual cuja característica é a atração tanto por indivíduos de ambos os sexos quanto por objetos, plantas, etc.

55 O metrossexual é um termo cunhado por Mark Simpson cujas características são morar na cidade e gastar dinheiro com seu corpo, como fazer depilação, manicure e pedicure, passar cremes, usar roupas da moda, enfim, preocupar-se com seu visual, ser vaidoso. 
Esse diálogo acontece entre duas personagens masculinas que representam dois homens angustiados, como podemos observar pela expressão facial de tristeza e insatisfação. Essa insatisfação se deve à comprovação, deduzida da conversa mantida entre os dois sujeitos, de que eles gostariam de ser aquele homem que apreciava simplesmente mulher, futebol e cerveja. Assim, a fala desses personagens remete aos valores sólidos do sujeito masculino, nos quais ele era considerado pelos discursos do senso comum como um ser tradicional.

Os efeitos de sentido produzidos constroem uma imagem de novo homem a partir de uma identidade que se move entre todos os tipos de homens possíveis na atualidade. O diálogo presente nessa mídia projeta alguém que deixa de ser uno para ser vários e, por isso, está angustiado diante das novas exigências sociais. A vinda da Pós-Modernidade, cuja característica é a multiplicidade, o desapego a apenas uma identidade, fez com que o homem se dividisse.

Nsse exemplo vislumbramos a angústia masculina diante de sua nova posição social. Esses enunciados mostram um homem em crise com a nova posição ocupada: alguém angustiado, perdido, que almeja se encontrar em meio a tantas novidades. O que teria feito surgir enunciados como esses, tornando visível um sujeito angustiado? A crise de identidade encontrada nos enunciados tem suas raízes nas quebras de paradigmas que, durante muito tempo, deram estabilidade à posição social ocupada pelo homem. Com a chegada do Pós-Modernismo uma pluralidade de valores é oferecida, compondo uma mistura de diferentes estilos, abertos, efêmeros. O modismo — descartável e fugaz — por conta de tanta diversidade entrou no lugar do fixo, do imutável. Essa diversidade tem sido oferecida principalmente pelo sistema capitalista, na busca de ampliar mercados. Novos atrativos são oferecidos para 
que os velhos sejam descartados. Muitos homens possuem medo de não acompanhar essa fluidez, essa efemeridade, por isso estão em crise, perdidos. Como pondera Bauman (2007), a vida líquida faz o ser humano ter medo de não acompanhar a rapidez das coisas, medo de ficar para trás, de não conseguir acompanhar o que dita a moda do momento, de não poder comprar a última versão daquele celular, por exemplo. A pouca durabilidade dos produtos é uma prova dessa efemeridade.

Nossa sociedade é levada pelo consumir. Sempre queremos ter, não há satisfação completa. $\mathrm{Na}$ vida moderna o sujeito se sente livre para escolher, fazer o que quer sem ser submisso a ninguém, embora essa liberdade traga sofrimentos, crises, incertezas, medo. Tudo isso se reflete nos sentimentos masculinos, porque essa liberdade está na contramão dos valores da sociedade machista há tanto tempo cultivados. Essa nova ordem do discurso é taxativa: atitudes modernas são elogiadas, e as machistas e patriarcais, reprimidas.

A produção dos sentidos veiculados pelas duas mídias aqui selecionadas pode dever-se à presença das memórias discursivas, as quais evocam a representação do homem forte, que não demonstra sentimentos e angústias, pois manifestações dessa ordem sãoreservadas às mulheres. Por causa disso a mulher sempre foi considerada o sexo frágil, que se deixa levar pela emoção, enquanto, discursivamente, o homem deixa se levar pela razão. Não obstante, ocorre um novo deslocamento a partir do novo imaginário veiculado pela mídia: aquele indivíduo seguro, forte, frio e agressivo começa a cair por terra para dar lugar a um homem sentimental, o qual não precisa mais esconder o que sente. Ocorre nesses enunciados uma construção histórica, e não biológica, pois mostrar fraquezas, ser sensível, perder o posto de 
autossuficiente, etc. são condições que não têm nada a ver com ser forte fisicamente ou não.

Par melhor visualizarmos essas considerações construímos a tabela abaixo.

Tabela 01 - O processo de deslocamento da identidade do homem.

\begin{tabular}{|l|l|}
\hline \multicolumn{2}{|c|}{ O processo de deslocamento da identidade do homem } \\
\hline \multicolumn{1}{|c|}{ Retomadas do arquivo } & \multicolumn{1}{|c|}{ Deslocamentos do arquivo } \\
\hline $\begin{array}{l}\text { A mulher era considerada o sexo } \\
\text { frágil, sentimental e inferior. }\end{array}$ & $\begin{array}{l}\text { O homem também manifesta seus } \\
\text { sentimentos e se angustia, podendo se } \\
\text { enquadrar no sexo frágil. }\end{array}$ \\
\hline $\begin{array}{l}\text { O homem era considerado o sexo } \\
\text { forte, um ser racional, forte, frio } \\
\text { e seguro de si, de sua identidade } \\
\text { de macho. }\end{array}$ & $\begin{array}{l}\text { Homem em crise, acuado diante } \\
\text { de tantas mudanças e da falta de }\end{array}$ \\
\hline
\end{tabular}

As memórias citadas na tabela são retomadas na produção de uma posição-sujeito em crise; com isso, ocorre um deslocamento das identidades, caracterizando o homem moderno como um sujeito angustiado. Em outras palavras, essa série enunciativa aqui descrita expõe a crise e a fragmentação das identidades de gênero na Pós-Modernidade.

\section{Considerações finais}

Os enunciados midiáticos analisados neste texto constituem uma amostra de um discurso muito recorrente na mídia brasileira 
contemporânea, o qual se vale do funcionamento discursivo linguístico e imagético que promove a formação e a manutenção de uma formação discursiva que se sobrepõe às identidades de gênero.

A prática discursiva midiática é fundamental na divulgação desse "novo homem": seus discursos evidenciam a crise da identidade masculina, tornam visível o sujeito angustiado. Talvez muitos homens não se tenham dado conta do momento histórico vivido, mas ao serem interpelados pela mídia através de reportagens, propagandas, programas, etc., podem começar a ter consciência desse novo panorama espetacularizado na série enunciativa aqui analisada.

O poder da mídia é exercido, e não é realizado de qualquer maneira, haja vista que ela se vale de saberes como a psicologia, a medicina, o marketing e muitos outros para legitimar seus discursos. Destarte, nem todos os homens vivem essa mesma temporalidade, o que atesta uma descontinuidade na História, pois, embora as reportagens materializem o sentido de novo homem, o outro desse discurso aparece e aponta as brechas e as resistências. As análises mostram que a chamada crise masculina advém do fato de que as metamorfoses do macho não são sempre aceitas de modo passivo.

Essa nova maneira de discursivizar o homem emerge do momento histórico atual porque o solo epistemológico permite que tratemos assim os sujeitos. Tais discursos surgiram, como vimos, a partir da confluência de várias causas, como as conquistas feministas, as revoluções sociais manifestadas partir da década de 1960 e as investidas do mercado capitalista, cujas consequências são inúmeras, entre elas a crise de certos paradigmas sociais que norteavam os papéis femininos e masculinos. 


\section{Referências}

ALVES, B. M.; PITANGUY, J. O que é feminismo. São Paulo: Brasiliense, 1981.

BAUMAN, Z. O Mal-Estar da pós-Modernidade. Rio de Janeiro: Jorge Zahar., 1998.

. Globalização: as consequências humanas. Rio de Janeiro: Jorge Zahar., 1999a.

. Modernidade e ambivalência. Rio de Janeiro: Jorge Zahar, $1999 \mathrm{~b}$.

- A Sociedade líquida. Folha De S. Paulo, domingo, 19 de outubro de 2003. Mais!

. Vida Liquida. Rio de Janeiro: Jorge Zahar, 2007.

CONFORTLIN, H. Discurso e Gênero: a mulher em foco. In.:

GHILARDI-LUCENA, M. I. (org.). Representações do feminino. Campinas: Átomo, 2003.

CURCINO-FERREIRA, L. Técnicas de Individualização da Instauração de Identidade do Leitor-Modelo na Revista. In: FONSECA-SILVA, M. C. e POSSENTI, S. (orgs.). Mídia e Rede de memória. Vitória da Conquista: Edições Uesb, 2007.

FONSECA-SILVA, M. C. Mídia e lugares de memória discursiva. In: FONSECA-SILVA, M. C.; POSSENTI, S. (orgs.). Mídia e rede de memória. Vitória da Conquista: Edições Uesb, 2007.

FOUCAULT, M. Microfísica do poder. Rio de Janeiro: Edições Graal, 13. ed., 1998.

GHILARDI-LUCENA, M. I. (org.). Representações do feminino. Campinas: Átomo, 2003.

GREGOLIN, M. R. V. Apresentação. In: GREGOLIN, M. R. (org.). Discurso e mídia: a cultura do espetáculo. São Carlos: Claraluz, 2003a. 
O acontecimento discursivo na mídia: metáfora de uma breve história do tempo. In: GREGOLIN, M. R. (org.). Discurso e mídia: a cultura do espetáculo. São Carlos: Claraluz, 2003b.

Discurso, História e Produção de Identidades na Mídia. In:

FONSECA-SILVA, M. C. e POSSENTI, S. (orgs.). Mídia e Rede de memória. Vitória da Conquista: Edições Uesb, 2007.

HALL, S. A Identidade Cultural na Pós-Modernidade. Rio de Janeiro: DP\&A, 1997.

SANTOS, J. F. O que é pós-moderno. Brasiliense. 7 ed. [s.d.]. (Coleção primeiros passos, n. 165).

SGARBIEIRI, A. N. A mulher brasileira: representações na mídia. IN:

GHILARDI-LUCENA, M. I. (org.). Representações do feminino. Campinas: Átomo, 2003. 


\section{SER MULHER NA ATUALIDADE:}

A REPRESENTAÇÃO DISCURSIVA DA IDENTIDADE FEMININA EM QUADROS HUMORÍSTICOS

DE MAITENA

Érika de Moraes $^{56}$

É fato que a condição social da mulher mudou muito, especialmente após a chamada Revolução Feminista da década de 1960. Antigamente era inadmissível a mulher ter direitos que, ao mundo de hoje, soam tão naturais, como estudar, trabalhar fora do lar, votar, etc. Embora direitos como esses representem conquistas femininas (ou feministas), há que se considerar, também, que são fruto de conjunturas históricas específicas.

Exemplo disso é o fato de que a inserção da mulher no mercado de trabalho, historicamente, ganhou legitimidade no momento em que a situação econômica das famílias não permite ao homem sustentar sozinho a casa. Por essa razão, discussões a respeito das condições de trabalho do proletariado feminino (operárias, costureiras) só adquiriram intensidade junto aos movimentos feministas "à medida mesmo em que as transformações sociais e os acontecimentos políticos, como a

56 Professora do Programa de Pós-Graduação da Universidade do Sagrado Coração, USC, Bauru, SP. 
primeira guerra mundial, forçaram a entrada cada vez maior das mulheres no mundo público" (RAGO: 1995-6, p. 22). Não se trata de apagar ou reduzir as conquistas das mulheres, tampouco o valor das lutas feministas, mas de considerar o peso da conjuntura histórica nos acontecimentos.

Também as condições histórico-culturais influenciam os discursos que circulam em relação à mulher e, como efeito, constroem o sentido desses mesmos discursos. Com a mudança dessas condições, discursos assumidamente machistas tendem a perder a sua legitimidade. Enunciados do tipo "lugar de mulher é na cozinha" não têm boa aceitação numa época que valoriza, na medida do possível, o comportamento considerado politicamente correto.

Não obstante, em alguns domínios, como o humorístico, tais discursos continuam a circular. É objetivo deste artigo discutir possíveis interpretações para a circulação, no humor, de determinados discursos sobre a mulher. Querem esses discursos dizer que a sociedade não mudou tanto quanto acreditamos? Trazem à tona sentidos recalcados? Ou retomam uma memória antiga, de discursos que já não circulam? Mas, se não circulam mais, por que ainda se encontram tão presentes em determinados domínios, como o do humor? Quais as relações entre esses discursos e a "realidade" de hoje? Quais as "novidades" representadas por esses discursos?

Os discursos cotidianos são um sintoma de que a sociedade ainda se pauta em valores sexistas, porém tais discursos se manifestam de novas formas. Uma análise dos textos que circulam atualmente na mídia (em reportagens de revistas, por exemplo) mostra que o estereótipo da mulher submissa foi substituído, em grande medida, pelo da mulher múltipla: que trabalha fora, cuida 
da casa, dos filhos e do marido e, ainda assim, deve encontrar tempo para cuidar de si, fazer cursos de aperfeiçoamento, manter cabelos e unhas impecáveis, praticar exercícios físicos, balancear a dieta, etc. Pode-se mesmo dizer que o grau de exigência em relação à mulher tornou-se maior no conjunto de discursos dominantes de nossa sociedade: se antes a "mulher perfeita" era a que cuidava bem do lar e da família, hoje ela precisa se destacar profissionalmente sem descuidar das questões anteriores e, ainda, ter um corpo de modelo. Como isso tudo é quase impossível (até por razões fisiológicas, nem todas as mulheres poderão atingir o mesmo padrão de beleza), prevalecendo a sensação de "incompletude".

Não se pretende apenas defender, de modo simplificado, a tese segundo a qual, apesar de alguns avanços, a sociedade continua apresentando traços de "machismo". Trata-se, em vez disso (sem negar tal evidência), de procurar descrever e interpretar o modo como os discursos sobre a mulher emergem no humor e se confundem com a "realidade" sobre ela, produzindo efeitos na constituição da atual identidade feminina. Cabe também ressaltar que alguns discursos, que podemos chamar de androcentristas ${ }^{57}$, continuam a circular em espaços que não o humorístico, embora de formas mais sutis, vindo à tona nos vãos escorregadios da linguagem, nos interstícios do texto nos quais se mostram os posicionamentos dos sujeitos enunciadores.

Tendo esse objetivo em vista, pretende-se pôr em debate a questão de como os discursos que circulam no domínio

57 Montserrat Moreno (1999, p. 23) define o androcentrismo como um preconceito que "consiste em considerar o ser humano do sexo masculino como o centro do universo, (...) o único capaz de ditar as leis, de impor a justiça, de governar o mundo". Acreditamos que o termo possa ser apropriado para denominar a extensa Formação Ideológica que abriga inúmeros discursos (o do homem, o da mulher, o do pai, o da mãe, o da criança, etc.) e Formações Discursivas que se respaldam na centralidade do masculino. 
humorístico ajudam a constituir os (novos) efeitos de sentido sobre a identidade da mulher na atualidade. Sob a ótica da Análise do Discurso de linha francesa - doravante, AD - o(s) sentido(s) deve(m) ser entendido(s) aqui como um construto a partir dos discursos correntes a respeito da mulher e de seu (esperado) papel na atualidade. Consideramos o respaldo teórico-metodológico da AD pertinente para contribuir com esta discussão.

\section{Estereótipos no discurso: o masculino e o feminino}

Pierre Bourdieu (1998) defende que a cultura androcêntrica e a consequente "dominação masculina" estão de tal maneira arraigadas em nós que as tomamos como evidentes, deixando de notar o caráter historicamente construído de uma ordem social que é percebida como "natural". Bourdieu propõe a subversão dessa percepção equivocada: não são as diferenças naturais que definem as especificidades dos papéis sociais atribuídos a homens e mulheres, e sim, determinados papéis impostos a cada gênero é que fazem as diferenças parecerem naturais. Segundo o autor (ibid., p. 18), "a força da ordem masculina se evidencia no fato de que ela dispensa justificação: a visão androcêntrica se impõe como neutra e não tem necessidade de se enunciar em discursos que visem a legitimá-la”. Para ele,

\footnotetext{
As aparências biológicas e os efeitos, bem reais, que um longo trabalho coletivo de socialização do biológico e de biologização do social produziu nos corpos e nas mentes conjugam-se para inverter a relação entre as causas e os efeitos e fazer ver uma construção social
} 
naturalizada [...] como fundamento in natura da arbitrária divisão que está no princípio não só da realidade como também da representação da realidade [...]. (BOURDIEU, 1998, p. 9-10 - grifos nossos).

No nosso entender, não se trata de negar diferenças biológicas, mas de mostrar que muitas vezes elas se tornam justificativas - e não causa - das diferenças culturais. Comumente, a diferença biológica entre os sexos (especialmente quanto à anatomia do corpo masculino e do corpo feminino) é vista como "justificativa natural da diferença socialmente construída entre os gêneros e, principalmente, da divisão social do trabalho" (ibid., p. 20). Bourdieu nota que nem as mudanças sociais resolvem a questão, pois, "mesmo quando as pressões externas são abolidas e as liberdades formais" - direito de voto, direito à educação, acesso a todas as profissões, inclusive políticas - "são adquiridas, a autoexclusão e a 'vocação' [...] vêm substituir a exclusão expressa" (BOURDIEU, 1998, p. 52), dado que "os efeitos e as condições de eficácia" da violência simbólica "estão duradouramente inscritas no mais íntimo dos corpos sob a forma de predisposições (aptidões, inclinações)" (BOURDIEU, 1998, p. 51).

De nossa parte, acreditamos que a análise dos discursos sobre a mulher, especialmente no domínio humorístico, pode contribuir para a descrição (ou, pelo menos, o "clareamento") dessa inscrição simbólica "das estruturas sociais do corpo" e para certa tomada de consciência a esse respeito. Limitamo-nos, no entanto, a procurar explicitar esse jogo simbólico em relação a sentidos estereotipados para que, quem sabe, sua descrição discursiva ajude a proporcionar avanços quanto à formação de um espaço para novas ações e atitudes a partir e através dos limites deste texto. 


\section{A Análise do Discurso}

Para analisar o processo de construção dos (efeitos de) sentidos dos discursos sobre a mulher na atualidade e seus consequentes desdobramentos a partir do estudo da representação feminina no texto de humor, buscamos respaldo teórico na Análise do Discurso de linha francesa (AD).

Sem desconsiderar o percurso teórico historicamente constituído pela $\mathrm{AD}$, levaremos em conta um posicionamento atual da disciplina, segundo o qual, conforme ressalta Maingueneau (1987), o analista do discurso não busca estabelecer o 'sentido' por excelência, e sim, construir interpretações que não se neutralizem. Essa opção implica pensar que os processos discursivos podem ser apreendidos pela materialidade da língua, o que torna indispensável a atenção ao funcionamento da linguagem e justifica a opção por uma abordagem discursiva. Mobilizamos o conceito de discurso de Maingueneau (1984, p. 15), que o desenvolve, a partir da leitura de Foucault, como uma "dispersão de textos cujo modo de inscrição histórica permite definir como um espaço de regularidades enunciativas".

Acreditamos que o arsenal teórico da AD, segundo o qual a linguagem é concebida em sua materialidade histórica, possa munir o pesquisador de uma concepção crítica de linguagem que lhe permita aprofundar o estudo sobre as representações humorísticas a respeito da mulher e dos efeitos que estas produzem sobre o(s) sentido(s) corrente(s) em torno da identidade feminina na atualidade.

Para a $\mathrm{AD}$, o discurso não deve ser compreendido como o discurso empírico sustentado por um sujeito, tampouco confundido com o texto (embora ele possa ser apreendido por 
meio de textos). A noção de interdiscurso é indispensável para a concepção de discurso. Segundo Pêcheux, um dos principais fundadores da AD,

é impossível analisar um discurso como um texto, isto é, como uma sequência linguística fechada sobre si mesma, [...] é necessário referi-lo ao conjunto de discursos possíveis a partir de um estado definido das condições de produção (PÊCHEUX, 1969, p. 79).

Já que a língua é considerada em sua relação com a sociedade e a história, Pêcheux busca respaldo em outros campos que não o da Linguística, como a teoria da ideologia (com base, primordialmente, em Althusser) e a psicanálise (com base, primordialmente, em Freud e Lacan), sendo que

a relação da língua com a exterioridade não é pensada a partir de uma vaga noção de interdisciplinaridade mas sim como uma relação constitutiva de um objeto específico e de um campo de conhecimento que lhe corresponda e que esse objeto institui: o da análise do discurso (ORLANDI, 1998, p. 17).

Segundo a concepção da $\mathrm{AD}$, o discurso se constitui a partir de outros discursos, ou de um "discurso já lá". É na 'interdiscursividade' que a 'memória' é retomada e, embora vinda de um lugar exterior, deixa marcas no interior do discurso que permitem resgatá-la. Conforme Achard (1983, p. 11), é “a estruturação do discursivo [que] vai constituir a materialidade de uma certa memória social", o que implica que "a memória composta pelo discurso é sempre reconstruída na enunciação" (ACHARD, 1983, p. 17). A memória discursiva, para Pêcheux,

deve ser entendida [...] não no sentido diretamente psicologista da 'memória individual', mas nos sentidos entrecruzados da memória mítica, da memória social inscrita em práticas, e da memória construída do historiador (PÊCHEUX, 1983, p. 50). 
Como o discurso é produto do 'interdiscurso', busca-se identificar os diferentes discursos que circulam sobre a mulher nas representações humorísticas sobre ela e como esse jogo (inter) discursivo constituído por discursos heterogêneos (ou, em alguns casos, homogeneizantes) ajuda a construir 'o(s) sentido(s)' dos discursos (em geral) sobre a 'identidade feminina' na atualidade. Para tanto, mobilizamos vários conceitos da $\mathrm{AD}$, entre os quais as noções cruciais já expostas de 'interdiscurso e memória discursiva', além de outras desenvolvidas mais recentemente por Maingueneau, como a de ethos e a de 'cenografia', conforme explicitaremos a seguir.

Como afirma Maingueneau (1984, p. 21), o discurso não remete apenas a "um conjunto de textos efetivos", mas a "um conjunto virtual, o dos enunciados que podem ser produzidos de acordo com as restrições da formação discursiva". Embora o discurso seja uma 'dispersão', é no texto - produzido pelo trabalho dos sujeitos - que ele se materializa, fato que justifica que textos (verbais ou não verbais) sejam tomados como material para uma análise discursiva. A inclusão de aspectos não verbais em uma abordagem discursiva pode ser embasada na proposta de uma 'prática intersemiótica', vinculada a uma 'semântica global', conceitos de Maingueneau (1984) que considera como 'enunciados' o material propriamente linguístico - ou seja, os textos verbais - e como texto, qualquer tipo de manifestação, seja ela verbal (enunciado) ou visual (fotos, desenhos, ilustrações, obras de arte) (cf. MAINGUENEAU, 1984, p. 147). Daí a possibilidade de se considerar o discurso não só como uma prática de enunciados verbais, mas como algo que se manifesta também por meios iconográficos. Assim, nos textos humorísticos estudados podese pensar a concepção dos discursos sobre a mulher com base 
nos elementos verbais e não verbais desses textos (a ilustração, a expressão corporal e facial das personagens, etc.).

A AD se revela um lugar possível para pensar a questão da 'subjetividade' no discurso, o que é particularmente relevante no que diz respeito à constituição da subjetividade feminina em relação aos discursos sociais acerca da mulher. Neste sentido, a análise de discursos nos quadros humorísticos sobre a mulher deve considerar a constituição do chamado ethos, que Roland Barthes (apud MAINGUENEAU, 2000) define como

os traços de caráter que o orador deve mostrar ao auditório (pouco importa a sua sinceridade) para causar boa impressão: são os ares que assume ao se apresentar. [...] O orador enuncia uma informação e, ao mesmo tempo diz: eu sou isto, eu não sou aquilo.

Maingueneau (2000,p.98), acrescenta que "a eficácia do ethos se deve ao fato de que ele envolve de alguma forma a enunciação, sem estar explícito no enunciado" e que, diferentemente de como era entendido pela retórica antiga, o ethos não diz respeito apenas aos enunciados orais, mas é válido também para o discurso escrito, assim como para qualquer outro, instituindo um 'tom' que dá autoridade ao que é dito:

Com efeito, o texto escrito possui, mesmo quando o denega, um tom que dá autoridade ao que é dito. Esse tom permite ao leitor construir uma representação do corpo do enunciador (e não, evidentemente, do corpo do autor efetivo). A leitura faz, então, emergir uma instância subjetiva que desempenha o papel de fiador do que é dito (MAINGUENEAU, 2000, p. 98).

Assim, a ideia de ethos implica assumir que 'não se diz' explicitamente 'como' ou 'o quê' se é, mas 'mostra-se', por meio de atitudes (físicas ou discursivas), como e o quê se é. No caso do discurso humorístico, esse conceito é certamente 
crucial para uma melhor explicitação das especificidades do próprio discurso no que tange à construção da identidade feminina.

Amossy (2005, p. 16) explica que "a noção de ethos se desenvolveu de forma articulada à de cena de enunciação". isto significa que a maneira de dizer implica a construção de uma imagem de si que o receptor se vê obrigado a depreender "a partir de indícios discursivos". É na enunciação que o locutor constrói a imagem de si e, a partir dela, legitima o seu discurso, ao mesmo tempo em que, de certa forma, constrói a sua identidade. É objetivo de uma análise do discurso descrever e interpretar esses "indícios discursivos" que levam à constituição de um certo ethos.

Maingueneau (2006, p. 47) mostra que as situações de enunciação se constituem no quadro de uma "cena de enunciação", que não se confunde com um simples quadro empírico, mas "se constrói como cenografia por meio da enunciação". Segundo essa concepção, "o discurso implica um enunciador, um coenunciador, um lugar e um momento da enunciação que valida a própria instância que permite sua existência", sendo que a "cenografia é ao mesmo tempo dada e construída".

Seguindo os conceitos de Maingueneau (2005, p. 75), constatamos em nossa análise que a 'cena englobante' que correspondente ao tipo de discurso e a ele confere seu estatuto pragmático é o discurso humorístico. A 'cena genérica', que é a "do contrato associado a um gênero, a uma 'instituição discursiva", é caracterizada por um tipo específico de gênero humorístico (os quadros de humor). Já a 'cenografia' - que comporta a construção de um ethos específico, amparado em situações constituídas pelos estereótipos existentes, memória 
discursiva e interdiscurso -, é específica para cada caso, por isso será descrita nas análises. É importante ressaltar, com Maingueneau (2006, p. 47), que a cenografia não deve ser interpretada como uma simples cena ou um quadro estável, mas deve ser concebida "ao mesmo tempo como quadro e como processo"; ou seja, "o discurso implica uma certa situação de enunciação, um ethos e um 'código linguageiro' através dos quais se configura um mundo que, em retorno, os valida por seu próprio desenvolvimento". "A cenografia é, assim, ao mesmo tempo, aquela de onde o discurso vem e aquela que ele engendra; ela legitima um enunciado que, por sua vez, deve legitimá-la” (MAINGUENEAU, 2005, p. 77).

Vale lembrar que a noção de ethos - fundamental para a (re)constituição da cenografia da qual participa e deriva - está diretamente ligada à enunciação, "não a um saber extradiscursivo sobre o enunciador" (MAINGUENEAU, 2005, p. 70); e "longe de situar-se na nascente do texto [...], o tom específico que torna possível a vocalidade constitui para nós uma dimensão que faz parte da identidade de um posicionamento discursivo". (MAINGUENEAU, 2005, p. 73). Assim o ethos, mais do que um meio de persuasão, é "parte constitutiva da cena de enunciação, com o mesmo estatuto que o vocabulário ou os modos de difusão que o enunciado implica por seu modo de existência”. (MAINGUENEAU, 2005, p. 75).

As noções de cenografia e ethos são mobilizadas em nossas análises a fim de se especificar a imagem de mulher construída nos quadros de humor que a representam. O corpus deste trabalho é constituído por textos humorísticos que representam a figura feminina, e, consequentemente, lidam com a problemática de gêneros. A título de delimitação, trabalharemos, aqui, com os 
quadros de humor da humorista Maitena ${ }^{58}$, encontrados nos livros da série Superadas, Volumes 1 e 2, publicados no Brasil pela Editora Rocco. De um total de 291 quadros, apresentaremos as análises de um conjunto representativo dos principais discursos contemporâneos sobre a mulher.

Ainda que "crucialmente ligado ao ato de enunciação, não se pode ignorar, entretanto, que o público constrói representações do ethos do enunciador antes mesmo que ele fale" (MAINGUENEAU, 2005, p. 71), daí a distinção entre ethos discursivo e ethos pré-discursivo. Segundo o autor, "mesmo que o coenunciador não saiba nada previamente sobre o caráter do enunciador, o simples fato de que um texto pertence a um gênero de discurso, ou a um certo posicionamento ideológico, induz expectativas em matéria de ethos". (MAINGUENEAU, 2005, p. 71).

O fato de se tratar de humor (cena englobante) remete à competência genérica do leitor, que, pelo imaginário que tem sobre o gênero, possivelmente espera de antemão uma representação exagerada da figura feminina e das cenas cotidianas que supostamente a mulher vivencia, embora o exagero possa ser dado ou não pela cenografia. Como se trata de uma humorista bastante conhecida, pode-se também supor que boa parte de seus leitores tenha seus textos como característicos de um humor

58 Maitena, humorista argentina, é famosa mundialmente e, no Brasil tem quadros publicados aos domingos no jornal Folha de São Paulo e, mensalmente, na Revista Claudia, Editora Abril. O fato de uma autora do sexo feminino destacar-se como humorista, por si só, constitui um avanço em relação à condição da mulher, já que o humor historicamente foi dissociado de uma "cultura feminina". Halifax, por exemplo, acreditava que o riso devia ser evitado, especialmente pelas mulheres, por ser "uma característica de tipo baixo, que reduz a mulher a uma condição inferior e a degrada da classe daquelas que são mais refinadas" (HALIFAX: 1969 apud SKINNER: 2002, p. 70). 
crítico. Isso não invalida o fato de que é na enunciação que se constitui o ethos das personagens criadas por Maitena.

É pela construção de um ethos sustentado por fiadores convincentes (as personagens construídas por Maitena - e pelo próprio nome de autor Maitena) que se dá a identificação com as leitoras e o consequente volume significativo de vendas da obra (o que pode ser depreendido das reedições e da superexposição desses livros em livrarias físicas ou virtuais).

\title{
Identidade "Superadas" - Maitena e os discursos contemporâneos sobre a mulher
}

\section{Mulheres superadas: sobrecarregadas}

\author{
Superadas 1, p. 19 \\ (homem 1, com criança no colo) Como a vida muda, né? Depois de \\ passar as primeiras férias de minha vida o dia todo com minha filha de \\ um ano, descobri coisas incríveis... \\ (homem 2) Claro, a dimensão da relação pai-filha, a diferença entre ser \\ casal e ser família, a... \\ (homem 1) Não, que ir para o escritório é um descanso!
}

Os protagonistas do quadro descrito acima são homens, mas o discurso posto em circulação diz respeito muito à mulher, já que somente nas férias do trabalho o homem "descobre coisas incríveis", ao passar o dia todo com a filha. O homem 1 tem no colo uma criança pequena que usa fralda e um chapeuzinho cor-de-rosa. Não é possível ver os olhos do homem 1, pois estão tapados pelas mãos da criança. Pelo que diz (descobri [...] que ir 
para o escritório é um descanso), tem-se implícito que, "antes das férias, ele não sabia disso". Só vivendo "na pele” o papel de pai "em período integral" é que ele pode compreender o trabalho de cuidar de uma criança e, consequentemente, entender o trabalho e o cansaço típicos de uma mãe. $\mathrm{O}$ aspecto de novidade do discurso aí representado em relação a tempos passados consiste em que, ainda que demore (precisa ter férias para isso), o homem chega à descoberta e ao possível reconhecimento de que cuidar de uma criança, tarefa (estereo) tipicamente associada à mulher, dá trabalho (mais que o escritório).

\section{Superadas 1, p. 93}

(mulher 1) Me diz, querida... não está precisando de umas férias? Você parece cansada, com cara de esgotada, estressada, sei lá...

(mulher 2, ao lado de duas crianças) É que acabo de voltar de férias...

O quadro acima descrito reforça o discurso de que "cuidar de crianças é mais cansativo do que trabalhar fora". A mulher 1 vê a mulher 2 com expressão de cansada e supõe que tal cansaço se deva ao emprego, mas a resposta da mulher 2 revela tratar-se do contrário. Os elementos visuais que ajudam a compor a cena - a presença de duas crianças - mostram que são os filhos a razão do cansaço; ou seja, segundo esse posicionamento, filhos causam mais cansaço do que o escritório, o que remete à sobrecarga feminina. Num certo sentido, este quadro desconstrói um posicionamento machista segundo o qual as tarefas culturalmente relegadas à mulher (como cuidar de filhos) são "mais fáceis" do que aquelas realizadas fora do lar (como exercer uma profissão), historicamente relacionadas ao sexo masculino.

\section{Superadas 2, p. 18}

(mulher 1, segurando bolsa e compras na mão) Não acredito! Como pode uma garota como você, tão feminista, dizer que se voltasse a nascer queria ser homem? 
(mulher 2, segurando várias coisas nas mãos e as chaves, na boca)... Para ter uma esposa, meu bem.

No quadro acima, a mulher 1 questiona o que a mulher 2 teria dito sobre querer ser homem se voltasse a nascer. Essa fala da mulher 2 não é explicitada, mas fica pressuposta pelo enunciado da personagem 1. A mulher 1 demonstra indignação (Não acredito) por saber que a mulher 2 , sendo uma feminista (dado pressuposto pelo enunciado da mulher 2), demonstra vontade de ser homem. A resposta da mulher 2 (Para ter uma esposa, meu bem), aliada aos elementos visuais que compõem a cenografia (mãos carregadas de objetos, demonstrando necessidade de tomar várias providências em pouco tempo), converge para o discurso segundo o qual "os homens não são/estão tão sobrecarregados quanto as mulheres”, e nesta perspectiva, é mais fácil e menos cansativo ser homem do que ser mulher. Quando diz 'para ter uma esposa', a personagem sinaliza um dado relevante: não é essencialmente por ser homem que a vida deles é mais fácil, mas por "ter uma esposa"; ou seja, ao tomar para si diversas tarefas, a mulher estaria facilitando a vida dos homens. Esse discurso remete ao posicionamento de que as mulheres têm responsabilidade decisiva na manutenção de comportamentos.

\footnotetext{
Superadas 2, p. 46

(mulher) Tratem de se mexer um pouco!! Eu sou o quê, hein? A empregada da casa?!

(filha) Mas, mãe, como pode dizer isso...? Se fosse a empregada, pelo menos teria os fins de semana livres.
}

$\mathrm{Na}$ cenografia deste quadro o cenário é o lar: a menina está com um telefone à mão, enquanto um menino está deitado, segurando um controle de tevê, e ao seu lado há comida e refrigerante. A expressão da mulher, a mãe, 
caracteriza-a como 'sobrecarregada e estressada'. Suas mãos estão em expressão nervosa, com os dedos contorcidos. Ela tem olheiras e gotas de suor escorrem de seu rosto. Os filhos têm expressão relaxada e tranquila. Pressupõe-se que "eles não fazem nada" (e/ou "tiram as coisas do lugar"), já que a mãe diz 'Tratem de se mexer um pouco! 'e, além disso, a cena visual mostra os jovens "parados", reforçando a ideia de que "eles não se mexem". Quando a filha diz 'Mas, mãe, como pode dizer isso...? "poder-se-ia esperar um consolo para a mãe, algo como "imagine, você é nossa mãe, como pode se considerar uma empregada?”. Como é típico do humor surpreender, o desfecho do quadro quebra essa expectativa positiva ao apresentar um argumento negativo, que só serve para confirmar o mal-estar da mãe: 'Se fosse a empregada, pelo menos teria os fins de semana livres'. A filha poderia, ainda, dizer que a mãe "receberia um salário pelo trabalho doméstico", e o efeito seria semelhante. O menino não produz enunciado verbal, como se nada que o afetasse estivesse acontecendo ao redor; mas sua postura estática e o olhar fixo (provavelmente, voltado para a televisão, o que se subentende pelo controle remoto em sua mão) confirmam o pressuposto do enunciado da mãe (de que os filhos não ajudam em nada e ela tem de pôr a casa em ordem sozinha). Trata-se, mais uma vez, de uma cenografia que representa a 'sobrecarga' da mulher nos dias atuais.

\section{Mulheres superadas: (in)dependentes (de um homem)}

\section{Superadas 1, p. 28}

(homem) Me desculpe, sim? Mas eu não estou acostumado com mulheres como você. Escolheu o restaurante, serviu o vinho, pagou 
metade da conta e agora viemos a uma boate e vai dançar sozinha... quer saber? Fui!

(mulher, com lágrima no olho) Como é? E não vai me levar em casa...?

O enunciado do homem revela que se trata de uma mulher independente: ela escolhe o restaurante, serve o vinho, paga metade da conta, dança sozinha... O ethos de mulher moderna e independente é também construído pelo seu visual despojado: ela tem os cabelos curtos (símbolo de praticidade) e uma tatuagem no braço. Mesmo assim, ela espera dele que exerça uma "função de protetor". Desse modo, o quadro representa o discurso de que mesmo uma mulher independente precisa (quer) ter um homem para desempenhar algum papel em sua vida (como o de levá-la para casa, dar-lhe proteção).

\section{Superadas 1, p. 47}

(mulher 1) ... Depois do que passei ontem à noite, percebi que só é preciso uma coisa para brigar com dignidade com o namorado em público...

(mulher 2) Sim, claro... calma, senso de ridículo, um pouco de razão... (mulher 1) Não... grana pra voltar sozinha de táxi.

O último quadro, de certa forma, traz um elemento novo ao acontecimento discursivo, defendendo o discurso de que "basta ter dinheiro para não ser dependente dos homens". Vistos em conjunto, os dois quadros acima representam discursos complementares e conflitantes, ou seja, mostram a contradição na constituição da identidade da mulher e de sua relação com o homem: as mulheres esperam dele o papel de protetor (que as leve para casa) e descobrem que basta não precisar dessa proteção (ter dinheiro para o táxi) para deixarem de ser dependentes dos homens. Ainda assim, mesmo não tendo necessidade da proteção, podem desejá-la, 
como no caso da mulher que sofre porque o homem não a levará para casa.

\title{
Mulheres superadas: detalhistas e complexas em suas emoções
}

\author{
Superadas 1, p. 11 \\ (mulher, sentada diante de um médico) Desculpe, doutor, mas... onde \\ é que se injeta colágeno para preencher o vazio existencial?
}

Do ponto de vista técnico, o humor, no quadro descrito acima, é provocado por uma quebra de expectativa em relação à pergunta. Quando se fala em colágeno, um recurso estético em evidência na atualidade, espera-se que a mulher esteja interessada numa mudança estética; no entanto a paciente expõe um problema interior (emocional), e não exterior (físico). Nesse breve enunciado são retomados vários discursos a respeito da mulher, vindos de memórias às vezes mais e às vezes menos recentes, entre eles os discursos sobre a preocupação da mulher com sua beleza, sobre sua futilidade (no sentido da preocupação estética ou de "ter tempo" para "dúvidas existenciais"), sobre a mulher cercada por problemas emocionais e sobre o lugar da mulher como um lugar de "falta" (a mulher necessita de um complemento, estético ou existencial; sempre necessita de ajuda, de amparo), cuja representação típica é justamente a do consultório médico ou terapêutico.

\section{Superadas 1, p. 25}

(homem) Não acredito! Esqueci os cartões de crédito!!

(mulher) Não se preocupe, a gente tem que voltar mesmo... eu esqueci a pinça de depilação!! 
Já no quadro acima, a personagem exagera a importância do esquecimento de uma pinça de depilação, dando a esse objeto mais importância que ao cartão de crédito (diz que iam ter de voltar 'mesmo', por causa do esquecimento da pinça, ainda que não fosse o esquecimento do cartão). O cenário em que se passa essa cena é visivelmente um quarto de hotel, onde o casal está abrindo as malas. Evidentemente, numa situação real, seria considerado o fato de que uma pinça pode ser facilmente comprada; mas a ideia serve para caracterizar, com o exagero típico do humor, o estereótipo de que as mulheres dão importância exacerbada a certos detalhes, como aqueles relacionados à beleza (o cuidado da mulher com a aparência é representado aí pela importância dada à pinça de depilação).

O fato de a mulher ser mais reflexiva e se preocupar com detalhes é uma construção histórico-cultural que, por ter sido estimulada, com o tempo ganhou o status de "verdade", tornando-se um estereótipo corrente nos discursos sobre a mulher. As emoções femininas ora são tratadas como "profundas", ora caracterizam a mulher como alguém que se preocupa com "coisas pequenas". Essas duas posições conflitantes também constituem, na contradição, a identidade feminina.

\section{Mulheres superadas: maternais}

O tema da maternidade é recorrente no que se refere à representação da figura feminina. As cenografias representativas do papel da mulher como mãe convergem, sobretudo, para o discurso sobre a 'mulher sobrecarregada', dividida essencialmente 
entre a vida profissional e a do lar. A série Superadas trata da questão da maternidade na vida da mulher:

\section{Superadas 1, p. 146}

(homem, com lágrima de emoção nos olhos, e duas mulheres olham um bebê) Ao fundo, uma mulher, provavelmente a mãe, diz: ... E eu sou o quê, hein? Um seio à esquerda?

A cenografia deste quadro pode ser descrita da seguinte forma: três pessoas admiram um bebê no cesto, enquanto a mãe está ao fundo. Dessas três pessoas, uma, provavelmente, é o pai, que está com uma lágrima de emoção nos olhos; já as outras duas podem ser tias do bebê. O enunciado da mulher joga com a expressão "um zero à esquerda", numa referência ao fato de, depois de ter enfrentado os nove meses de gestação, o parto e agora a amamentação, as atenções serem todas voltadas para o bebê, ficando ela reduzida à função de amamentar (um seio) e esquecida (um zero à esquerda). Segundo o posicionamento deste quadro, a identidade da mulher-mãe é constituída como a de alguém que ficou esquecida e reduzida ao seu papel de provedora de leite; mas no conjunto da obra não é esse o único discurso que compõe a identidade da mulher-mãe, como se pode ver no exemplo a seguir:

\footnotetext{
Superadas 1, p. 147

(mulher 1) ... Qual foi a primeira coisa que perdeu quando teve o filho? A cintura? O sono? O tempo livre?

(mulher 2, com bebê no colo) ... Não, a objetividade. Olha, fala a verdade, não é ótimo quando ele arrota?
}

O último quadro expõe o estereótipo da "mãe coruja" que tudo admira em seu filho, até mesmo o arroto; mas não é de modo acrítico que essa ideia é aqui exposta, já que a enunciadora proposta por Maitena não só elogia o arroto do 
filho, mas principalmente assume que perdeu a objetividade. Assim, a identidade da mulher-mãe é constituída como a de alguém que perde a objetividade diante de seu filho. O arroto também significa o alívio do "dever cumprido" (última etapa da amamentação).

Destarte, os dois quadros acima representam discursos diferentes sobre a maternidade. No primeiro, a mulher reclama de as atenções serem todas voltadas para o bebê; no segundo, ela própria dedica atenção redobrada à criança. Os dados mostram que o interdiscurso sobre a mulher é composto por diversos discursos, às vezes conflitantes entre si. Todos eles interferem na construção dos efeitos de sentido sobre as questões relacionadas à vida da mulher e constituem a heterogeneidade da identidade feminina.

\section{Mulheres superadas: que sentem culpa}

\section{Superadas 2, p. 116}

(homem, entrevistando uma mulher, com um microfone) $\mathrm{O}$ que sente uma executiva de hoje, que tem sucesso, poder, responsabilidade, e que além de tudo é mãe de 3 filhos? (mulher) Culpa.

O discurso sobre a culpa feminina é recorrente na obra de Maitena. É interessante observar que a estrutura textual do quadro acima é muito semelhante à dedicatória de Maitena (onde a autora dá voz a si própria), constituindo quase uma paráfrase, em que a palavra 'culpa' é substituída por 'ajuda':

DEDICATÓRIA do livro de Maitena (Superadas 2)

Para Carmen 
De que pode precisar uma mulher que têm três filhos maravilhosos, um homem que a faz feliz e um trabalho que não pára de crescer? De ajuda.

Obrigada, Carmen.

\section{Conclusões: estereótipos que se repetem, porque circulam}

Os quadros de humor sobre a mulher representam (ainda que de forma exagerada) discursos que circulam, ou seja, não é só esse material que encena discursos que influenciam os efeitos de sentido sobre a figura feminina, esses discursos também aparecem em outros campos (como a literatura, o cinema, a telenovela), o que serve para reforçar sua representatividade no interdiscurso sobre a mulher. Esses discursos são retomados nos quadros da série Superadas, cuja análise permite propor uma definição aproximada de 'mulher' (ou da 'identidade feminina') tal qual é representada na obra de Maitena: trata-se de mulheres sobrecarregadas, (in)dependentes, detalhistas, complexas em suas emoções, maternais, que sentem culpa... ${ }^{59}$

Esses tópicos são relevantes em seu conjunto, pois ajudam a compor a 'semântica global' do discurso sobre a mulher, uma vez que condensam tanto aspectos textuais e visuais quanto a representação da memória discursiva. Como diz Maingueneau (1984, p. 85), “como no caso do vocabulário, o importante não

59 Uma análise mais minuciosa do humor sobre a mulher, incluindo obras de outros autores (como propusemos em nossa tese de doutorado, defendida em dezembro de 2008 no IEL/Unicamp), permite a apreensão de outros discursos, além de maior detalhamento das questões expostas. Por necessidade de delimitação, neste artigo, optamos por destacar os discursos mais recorrentes no que tange à constituição da identidade feminina. 
é o tema, mas seu tratamento semântico". A análise da obra de Maitena mostra que os vários discursos sobre a mulher podem ser complementares e ao mesmo tempo conflitantes, pois não correspondem a ideologias homogêneas, embora algumas possam predominar.

O discurso sobre as 'mulheres sobrecarregadas' relacionase com o da 'maternidade' e, simultaneamente, com o da 'mulher inserida no mercado de trabalho', já que é a necessidade de conciliar tarefas gerais (por exemplo, a carreira) com aquelas "tipicamente femininas" (especialmente as vinculadas ao seu papel de "reprodutora") que justifica a sobrecarga. Ao mesmo tempo, a sobrecarga gera a 'culpa' pela dificuldade em realizar bem todos os papéis esperados da mulher. $\mathrm{Na}$ composição da identidade feminina surge também a representação da preocupação da mulher com 'detalhes' e com o 'cuidado de si' (no humor de Maitena, em geral, a preocupação da mulher com a aparência/ beleza é representada especialmente pelo seu sofrimento por ter celulite).

Reunidos e analisados esses tópicos, cumpre mostrar as contradições dos discursos sobre a mulher. Ora, se ela é incompleta (necessitada de um complemento), por que seus papéis são múltiplos? Por que deve ser tão boa profissional e, ainda, ser uma mãe competente? Se ela sabe que isso equivale a uma sobrecarga, por que sente culpa? Se ela deve estar sempre bela (o cuidado de si é incentivado e cobrado da mulher), por que às vezes é considerada fútil por essa mesma preocupação (estereotipada como alguém que se preocupa mais com a pinça de depilação do que com o cartão de crédito)?

É justamente na contradição que é construída a identidade da mulher. Para Foucault (1969), as contradições podem ser vistas 
como um princípio organizador do discurso, o que é fundamental para a concepção de discurso da AD. Esse conjunto de traços (contraditórios) fundamenta os discursos que na atualidade se desdobram em diversos temas sobre a mulher. É certo que existe um fio condutor na constituição dos sentidos sobre a mulher (no qual ela é associada ao dilema entre carreira e maternidade, à culpa, à angústia/complexidade, à incompletude); no entanto, no tratamento semântico dado aos temas surgem as "zonas instáveis" (cf. MAINGUENEAU, 1984, p. 88), que abrem lugar para a contestação, os deslocamentos e a contradição, situando, assim, os discursos sobre a mulher num espaço de conflito, convergindo para uma 'identidade feminina em crise'.

Lembremo-nos, ainda com Foucault (1969), do princípio da raridade dos enunciados. Um conjunto pequeno de enunciados permite uma grande variedade de enunciações, associadas, por sua vez, a cenografias variadas. Sendo raro o enunciado, é comum que o mesmo enunciado possa vir à tona em variados tipos de enunciação, tanto num quadro de humor quanto numa capa ou reportagem de revista, por exemplo. Sugere-se ver, a esse respeito, a análise de Possenti (2007).

É possível afirmar que os trabalhos de Maitena reproduzem os mesmos estereótipos que aparecem nas revistas (estereótipos que não nascem nem na obra de Maitena nem na mídia, mas são nesses meios representados), porém o fazem ressaltando alguns dos discursos que são "contidos" em publicações consideradas "sérias" (não humorísticas).

Os dados apresentados reforçam a tese de que o texto de humor - como todo e qualquer texto -, embora não seja uma cópia fiel da realidade, é uma recriação dessa realidade a partir de dados da memória discursiva. No caso dos quadros de humor 
de Maitena, que envolvem a representação da mulher, tem-se, no nível argumentativo, a retomada de certos estereótipos e, por vezes, de preconceitos sobre a figura feminina. Mais do que reproduzir esses preconceitos, o humor os traz à tona, transportaos a um nível mais explícito, inclusive pelo exagero, que é típico desse gênero textual.

O ethos da mulher, segundo o humor, embora não corresponda exatamente ao ethos da mulher real, tem relação com este último e reforça estereótipos justamente através dos exageros. Em outras palavras, esses dois ethos se aproximam, porém no primeiro caso é retratado com uma carga de excesso. A exacerbação dos estereótipos, ao mesmo tempo em que diferencia os textos humorísticos daqueles construídos como 'sérios', ressalta aspectos sobre a imagem da mulher ora retratados, ora apenas sugeridos, servindo mais ou menos como uma 'lente de aumento' em relação à conflituosa identidade feminina.

Consideramos que o humor, tal como aparece nos quadros da humorista Maitena, seja crítico e criativo, por explicitar os discursos que circulam. Da maneira como são construídos, os quadros prestam-se mais a 'denunciar' situações, estereótipos e discursos dominantes do que a meramente reproduzi-los. A (necessidade de) mudança social extrapola os limites da teoria discursiva, no entanto, a explicitação de discursos pode ser um estágio fundamental para possíveis mudanças. Quanto aos caminhos complementares a serem trilhados, as pistas foram dadas desde a obra clássica de Simone de Beauvoir, quando esta autora defende a importância da consideração do aspecto 'humano' dos dois sexos acima das especificidades do feminino e do masculino: "o fato de ser um ser humano é infinitamente mais importante do que todas as singularidades que distinguem os seres 
humanos" (BEAUVOIR, 1949, p. 497). Só uma leitura simplista entenderia tal defesa como exclusão das especificidades.

\section{Referências}

ACHARD, P. Memória e produção discursiva do sentido. In: Achard, P. (Org.). Papel da memória. Tradução de José Horta Nunes. Campinas: Pontes, 1999.

AMOSSY, R Da noção retórica de ethos à análise do discurso. In: Imagens de si no discurso. São Paulo: Contexto, 2005.

BEAUVOIR, S. de. O segundo sexo: a experiência vivida (Vol. 2) Rio de Janeiro: Nova Fronteira, 1980.

BOURDIEU, P. A dominaşão Masculina. 2. ed. Tradução de Maria Helena Kuhner. Rio de Janeiro: Bertrand Brasil, 2002.

FOUCAULT, M. (1969) A arqueologia do saber. Rio de Janeiro: Forense, 1987. (1979) Microfísica do poder. 12. ed.Organização, Introdução e Revisão Técnica de Roberto Machado. Rio de Janeiro: Graal, 1996, p. 229-242.

MAINGUENEAU, D. (1984). Gêneses do discurso. Tradução: Sírio Possenti. Curitiba: Cria, 2005. . Novas tendências em análise do discurso. 3. ed. Campinas: Pontes/ Editora da Unicamp, 1997. . Análise de textos de comunicașão. São Paulo: Cortez, 2000. . Ethos, Cenografia, Incorporação. In: AMOSSY, R. Imagens de si no discurso. São Paulo: Contexto, 2005. Cenas da enunciacão. Organizado por Sírio Possenti e Maria Cecília Perez de Souza-e-Silva. Curitiba: Criar, 2006. 
MORENO, M. Como se ensina a ser menina: o sexismo na escola. Campinas: Editora da Unicamp/ Moderna, 1999.

ORLANDI, E. P. O próprio da análise do discurso. In: Discurso e política. Escritos no 3. Campinas: Labeurb, 1998.

PÊCHEUX, M. Análise automática do Discurso. In: Gadet, F.; Hak, T. (Org.) Por uma análise automática do discurso: uma introdução à obra de Michel Pêcheux. Tradução de Eni P. Orlandi. Campinas: Editora da Unicamp, 1990.

PÊCHEUX, M. Papel da memória. In: Achard, P. Papel da memória. Tradução de José Horta Nunes. Campinas: Pontes, 1999.

POSSENTI, S. Discurso Humorístico e Representações do Feminino. Estudos da língua(gem): representações do feminino. Vitória da Conquista. n. 1, V. 5, jun. 2007.

RAGO, M. Adeus ao feminismo? Feminismo e (pós) Modernidade no Brasil. In: Mulher, história e feminismo. CADERNOS AEL / Arquivo Edgard Leuenroth, n. 3/4. Campinas: Unicamp, IFCH, 1995/1996.

SKINNER, Q. Hobbes e a teoria clássica do riso. Tradução de Alessandro Zir. São Leopoldo: Unisinos, 2002.

\section{Referências bibliográficas do corpus}

BURANDARENA, Maitena. Superadas 1. Rio de Janeiro: Rocco, 2005.

BURANDARENA, Maitena. Superadas 2. Rio de Janeiro: Rocco, 2006. 



\section{PROFESSOR: \\ SUJEITO E OBJETO NA REVISTA NOVA ESCOLA \\ Adriana Beloti ${ }^{60}$, Pedro Navarro ${ }^{61}$}

\section{Considerações iniciais}

Este trabalho mobiliza algumas noções da $\mathrm{AD}$ para discutir como o discurso materializado na revista Nova Escola, nosso objeto de análise, colabora para a produção de identidades do professor, considerando, nesse sentido, as diferentes temporalidades.

Objetivamos, então, discutir como essa revista materializa em seus enunciados processos de subjetivação, isto é, como os sujeitos professores são objetos e sujeitos dos enunciados da Nova Escola. Como suporte teórico, metodológico e analítico lançamos mão das reflexões de Foucault e, ainda, de sociólogos e historiadores como Stuart Hall (2000; 2005) e Bauman (2001; 2005).

Para tanto, fazemos o seguinte recorte: traçamos primeiramente uma discussão sobre algumas concepções e noções de Michel Foucault, entre elas: discurso, formação discursiva, sujeito, descontinuidade e descentramento do sujeito, estas últimas a partir das discussões desse filósofo sobre a história
60 FECILCAM
61 UEM 
nova. Essas noções são operantes para este trabalho, na medida em que nos norteiam teórica, metodológica e analiticamente. Em seguida discorremos a respeito da atualidade e da "crise de identidade" pelo viés dos Estudos Culturais. Por fim, discutimos a constituição de identidades para o professor em enunciados veiculados em três edições da revista Nova Escola, os quais constituíram, então, o corpus da presente análise. Esses enunciados foram escolhidos por assumirem, marcadamente, a mesma posição-sujeito, conforme discutiremos na sequência.

\section{Michel Foucault e a análise do discurso: algumas noções operantes}

A concepção de discurso como prática sociodiscursiva torna-se fundante para os procedimentos teórico-metodológicos propostos por Michel Foucault. Em A arqueologia do saber esse filósofo define o discurso como um "conjunto de enunciados que se apoia em um mesmo sistema de formação" (FOUCAULT, 2007, p. 122). Como expõe Foucault (2007), o enunciado não pode ser definido em relação à frase, à proposição ou aos atos de linguagem, ao contrário, deve ser pensado em sua singularidade, em sua emergência como acontecimento discursivo cuja característica fundamental é o fato de ter "sempre margens povoadas de outros enunciados" (FOUCAULT, 2007, p. 110).

Conforme Gregolin (2008), na análise arqueológica de Foucault o enunciado não é tomado exclusivamente em seu aspecto linguístico, mas também em sua natureza semiológica. Tanto é assim que o filósofo se dedica à análise de enunciados 
verbais e não verbais. Neste sentido, Courtine (apud GREGOLIN, 2008, p. 29) pondera sobre a necessidade de "pensar o não verbal em seu funcionamento discursivo, em sua materialidade na História", o que exige, ainda, a superação das análises pelo viés estrutural. $\mathrm{Na}$ entrevista concedida a Cleudemar Fernandes (2010, p. 25), Courtine volta ao tema da semiologia e rediscute, a partir de Foucault, a natureza do enunciado e, assim, do discurso. Para o historiador, "o discurso não é um objeto linguístico".

Para Foucault, o discurso é um jogo estratégico e polêmico, incluído em séries discursivas, na dispersão e na descontinuidade histórica; é um espaço em que saber e poder se articulam. Em síntese, o discurso é uma prática que provém da formação dos saberes e se articula a outras práticas. É por meio dele que se constituem e se articulam as relações de saber e poder de certo momento histórico; além disso, o discurso está inseridos em formações discursivas:

No caso em que se puder descrever, entre um certo número de enunciados, semelhante sistema de dispersão, e no caso em que entre os objetos, os tipos de enunciação, os conceitos, as escolhas temáticas, se puder definir uma regularidade (uma ordem, correlações, posições e funcionamentos, transformações), diremos, por convenção, que se trata de uma formação discursiva... (FOUCAULT, 2007, p. 43).

A partir dessas duas noções fundamentais - discurso e formação discursiva - é possível entendermos que as escolhas e os usos lexicais e imagéticos ${ }^{62}$ evidenciam as várias formações discursivas que podem se fazer presentes em determinados enunciados, revelando os diversos discursos e, assim, as

62 Mesmo que não façamos, aqui, uma detalhada e minuciosa descrição e análise do texto imagético, por trabalharmos com enunciados sincréticos, não podemos desconsiderar o funcionamento discursivo das imagens em nosso corpus, até porque os enunciados são semiológicos, conforme pondera Foucault. 
posições-sujeito materializadas nesses enunciados. Neste sentido, mobilizamos outra noção fundante da AD: a de sujeito. Para Foucault (2007, p. 107), o sujeito não é a pessoa física, fonte e origem do enunciado, mas "um lugar determinado e vazio que pode ser efetivamente ocupado por indivíduos diferentes", lugar variável, que caracteriza a formulação como enunciado. O sujeito é, então, uma posição-sujeito que pode ser assumida segundo a "ordem do discurso".

A prática discursiva midiática já se legitimou na sociedade e, nessa condição, está autorizada a produzir e difundir culturas e enunciados postos como verdades. Ela constrói para si uma imagem confiável e, assim, exerce um poder que produz determinados saberes, "efeitos de poder". Como analisa Foucault, o poder "não pesa só como uma força que diz não, mas que de fato ele permeia, produz coisas, induz ao prazer, forma saber, produz discurso" (FOUCAULT, 1979, p. 8). Por isso a mídia faz circularem discursos que são autorizados pelos mecanismos de saber e poder, já que as relações de poder se fazem presentes em todos os lugares e momentos da sociedade.

No discurso midiático, conforme Foucault (2009), há uma "ordem do discurso" que determina quem e como se pode falar, sobre qual assunto, em que momento histórico-social. Com base em nosso corpus de análise apresentamos como exemplo o fato de que essa ordem exerce o poder de produzir saber e efeitos de sentido sobre a prática docente e produz imagens ou representações de identidades de professor. Isso se deve ao fato de a prática discursiva reunir e materializar relações de saber e poder que dizem e determinam o que é "ser professor" e "como devem ser as práticas docentes".

Ao nos propormos analisar como a revista Nova Escola materializa em seus enunciados processos de subjetivação e 
constrói identidades para o professor, além das concepções já discutidas, outras noções propostas por Michel Foucault se fazem necessárias, entre elas a de descontinuidade e de descentramento do sujeito, pois é o descontínuo que faz surgir o acontecimento discursivo - entendido "não como uma decisão, um trabalho, um reino ou uma batalha, mas como uma relação de forças que se inverte, um poder confiscado, um vocabulário retomado e voltado contra seus utilizadores, uma dominação que se enfraquece, se amplia e se envenena e uma outra que faz sua entrada, mascarada" (FOUCAULT, 2005, p. 273). Além disso, quando é concebido como descentrado, o sujeito se torna objeto e sujeito desses acontecimentos, logo a continuidade deixa de ser considerada e o sujeito não é mais visto como a fonte e origem de todo devir e de toda prática.

Conforme Navarro (2004; 2008), Foucault, ao apresentar sua concepção genealógica de história contrapondo-a à concepção e ao método da história tradicional, afirma que a história deve preferir o monumento ao documento, a descontinuidade à continuidade, a heterogeneidade à homogeneidade e o descentramento do sujeito à noção de sujeito fundante.

Na História Nova, a ideia de linearidade, causalidade e continuidade é rejeitada e dá lugar a acontecimentos múltiplos, à multiplicidade dessa história descontínua, a diferentes tipos de duração. "A história não é, portanto, uma duração; é multiplicidade de tempos que se emaranham e se envolvem uns nos outros" (FOUCAULT, 2005, p. 293) - portanto o que predomina é uma história como dispersão, na qual a descontinuidade apresenta-se como uma operação deliberada do historiador e o resultado de sua descrição.

Apoiado em Nietzsche e em sua proposta genealógica, Foucault, no percurso da história geral, defende o descentramento 
do sujeito, o qual deixa de ser o centro dos acontecimentos discursivos e passa a ser objeto e sujeito desses acontecimentos. Esse novo foco explica-se pelo próprio objetivo da História Nova, que não estuda as personalidades históricas, mas os saberes. Em nossa pesquisa, por exemplo, o professor tanto é objetivado pelos enunciados da revista Nova Escola - ou seja, é objeto do funcionamento discursivo materializado em suas páginas - quanto é subjetivado, sendo, dessa forma, sujeito desses enunciados. É no entremeio dessa concepção de sujeito descentrado e disperso nos acontecimentos discursivos que objetivamos analisar a produção discursiva da identidade do professor em enunciados da revista Nova Escola a partir da consideração de que a prática discursiva identitária manifesta nessa revista estabelece relações de saber e poder que se projetam sobre as práticas pedagógicas e instituem processos de subjetivação docente.

Os nortes fundantes para as análises deste trabalho são discurso e formação discursiva, ordem do discurso, descontinuidade e descentramento do sujeito conforme são enunciados por Michel Foucault. A partir dessas proposições traçamos, na seção seguinte, algumas considerações a respeito da atualidade e da identidade, para depois discutirmos como a revista Nova Escola, por meio de processos de subjetivação, constrói identidades para o professor.

\section{Atualidade: reflexões sobre identidade}

Sociólogos filiados aos Estudos Culturais fundamentam suas análises sobre a sociedade contemporânea nas ideias de descentramento do sujeito e de fragmentação de identidades. 
Como um dos argumentos para essa crítica do tempo presente ressalta-se o fato de que alguns referenciais e nortes que garantiam uma identidade constante e cristalizada socialmente têm se fragmentado em uma dispersão, ocasionando a chamada "crise de identidade", conforme pondera Stuart Hall (2005). Além desse autor, Bauman (2001) é outro estudioso para quem a sociedade atual está sofrendo modificações, em virtude do que ele denomina "Modernidade Líquida".

A nosso ver, as características da presente fase estão diretamente relacionadas a um dos princípios básicos da história serial enunciada pelo filósofo Michel Foucault: a pluralidade de historicidades, a descontinuidade e as diferentes temporalidades de um mesmo momento histórico para diferentes sujeitos, de acordo com cada posicionamento diante dos saberes difundidos e legitimados socialmente e colocados como verdades. Neste sentido, a identidade na sociedade atual não é definitiva, pronta, acabada e fixa, mas se constitui justamente pelos processos de subjetivação, o que lhe garante o caráter de dinamismo, de estar em constante mudança e transformação.

É esse panorama geral que norteia nossas discussões sobre as identidades e os processos de subjetivação que constituem identidades para o professor por meio das práticas discursivas identitárias materializadas nos enunciados da revista Nova Escola.

Para Hall, o fenômeno da "crise de identidade", visto como algo característico da sociedade contemporânea, afeta aquelas identidades antes consideradas como sólidas, já cristalizadas na sociedade, as quais garantiam certa "estabilidade" às pessoas e às estratificações sociais. Devido aos deslocamentos e à dispersão dos acontecimentos discursivos, o ponto central de referência que determinava a identidade (de família, de nacionalidade, de 
gênero, de profissão, por exemplo) está passando por um processo de desestruturação, ocasionando o surgimento de "novas" identidades, em um processo de fragmentação dos sujeitos. Por isso a sociedade atual é tida como pertencente a um constante processo de ruptura, fragmentação e deslocamento.

Laclau (apud HALL, 2005, p. 16), ao analisar a noção de deslocamento, argumenta que

uma estrutura deslocada é aquela cujo centro é deslocado, não sendo substituído por outro, mas por uma "pluralidade de centros de poder". As sociedades modernas [...] não têm nenhum centro, nenhum princípio articulador ou organizador único e não se desenvolvem de acordo com o desdobramento de uma única "causa" ou "lei".

Nessa análise as identidades são constituídas pelas diferentes "posições de sujeito" que assumem os indivíduos inscritos em determinadas formações discursivas. Através das materializações discursivas, as identidades estariam, então, desenvolvendo-se em meio a rupturas, fragmentações e deslocamentos dos sujeitos, o que apontaria para as descontinuidades históricas que produzem saberes e às quais os homens estão sujeitos.

Outra possibilidade de olhar para esse contexto histórico é dada pelo sociólogo Zygmunt Bauman, para quem a sociedade atual vive as consequências do que ele chama de "Modernidade líquida". "Fluidez" ou "liquidez" são as metáforas utilizadas por Bauman para designar a natureza da presente fase, "nova de muitas maneiras, na história da Modernidade" (BAUMAN, 2001, p. 9).

No entender desse autor, a "Modernidade líquida" ou "leve" é voltada à fluidez das relações, na qual ocorre um processo de liquefação, de derretimento dos sólidos estabelecidos, no sentido de rompimento com o passado e a tradição, isto é, com 
a "Modernidade pesada". Bauman aborda também o tema da identidade com base na ideia de "Modernidade líquida", a qual

nos projeta num mundo em que tudo é ilusório, onde a angústia, a dor e a insegurança causadas pela "vida em sociedade" exigem uma análise paciente e contínua da realidade e do modo como os indivíduos são nela "inseridos". Qualquer tentativa de aplacar a inconstância e a precariedade dos planos que homens e mulheres fazem para as suas vidas, e assim explicar essa sensação de desorientação exibindo certezas passadas e textos consagrados, seria tão fútil quanto tentar esvaziar o oceano com um balde (BAUMAN, 2005, p. 8).

Isso significaria que na Modernidade há uma "quebra de formas", uma redistribuição e realocação dos "poderes de derretimento", em que tudo é muito rápido, flexível e está em constante processo de mudança, justamente pela característica da presente fase: "líquido-moderna", relacionada à fluidez e liquidez da sociedade, de seus "costumes" e "moldes".

Em relação às identidades, Santos (2006, p. 135) pondera que estas

não são rígidas nem, muito menos, imutáveis. São resultados sempre transitórios e fugazes de processos de identificação. Mesmo as identidades aparentemente mais sólidas, como a de mulher, homem, país africano, país latino-americano ou país europeu, escondem negociações de sentido, jogos de polissemia, choques de temporalidades em constante processo de transformação, responsáveis em última instância pela sucessão de configurações hermenêuticas que de época para época dão corpo e vida a tais identidades. Identidades são, pois, identificações em curso.

Nas reflexões desses autores sobre a relação entre sociedade, indivíduo e identidade ressalta-se o fato de que as identidades constituem-se e formam-se ao longo do tempo; não são inatas, mas estão em constante processo de formação; são incompletas, 
mas, de certa forma, revelam para o indivíduo quem ele é ou pode ser e como ele pode se constituir perante a sociedade.

Ao analisarmos a constituição identitária na mídia do ponto de vista da Análise do Discurso, objetivamos efetuar uma análise discursiva, ao passo que tomamos a produção de identidades como um fato de discurso. O sujeito disperso é, também, uma produção de determinados discursos, por isso não buscamos apenas discutir se há ou não uma fragmentação de identidades, conforme propõem autores da linha dos Estudos Culturais. A fragmentação de identidades e a perda de referenciais antes sólidos resultam do discurso sobre certas práticas. Como observado, em alguns discursos sobre as práticas docentes, por exemplo, não há liberdade para que o professor assuma sua fragmentação, ao contrário, os discursos apresentam um efeito de sentido de identidade docente "pronta para ser consumida". Além disso, nosso objetivo não é tomar posição ou oferecer elementos para um posicionamento de nossos leitores sobre a "qualidade" da revista Nova Escola, mas, discursivamente, abordar os enunciados materializados por esse veículo da mídia e seus efeitos nos processos de subjetivação e constituição de identidades do professor.

\section{A revista Nova Escola e o professor}

Tendo em vista certas tendências da $\mathrm{AD}$ ao analisar discursos midiáticos, julgamos necessário, primeiramente, conceber os discursos como práticas sociodiscursivas historicamente determinadas e a mídia como prática discursiva que materializa sentidos em suas formas enunciativas. Neste sentido, 
consideramos a mídia como espaço de produção e de circulação de efeitos de sentido na sociedade e como um dos principais lugares de enunciações em que se encenam e se constroem representações e identidades sociais e, por isso mesmo, um dos mais significativos mecanismos de subjetivação. Já legitimada na sociedade e autorizada a produzir e a difundir enunciados postos como verdades, ela exerce, através de seus discursos, um poder que produz saberes e "efeitos de poder".

Essa concepção justifica nosso corpus de análise. A revista Nova Escola é uma publicação pedagógica que já se consolidou no mercado editorial brasileiro, pois circula desde 1986. Surgida a partir de uma iniciativa da Fundação Victor Civita ${ }^{63}$, a Nova Escola alcançou tiragens expressivas e contribui para a construção de identidades.

De acordo com a jornalista Scalzo (2004), as revistas têm como principal característica e diferencial o fato de serem produzidas para um público específico, bem-definido e pretensamente homogêneo, enquanto o jornal, por exemplo, escreve para um público completamente heterogêneo. "A segmentação por assunto e tipo de público faz parte da própria essência do veículo. [...] É na revista segmentada, geralmente mensal, que de fato se conhece cada leitor, sabe-se exatamente com quem se está falando" (SCALZO, 2004, p. 14-15). Assim, a revista tem como foco o leitor, por isso deve conhecer e

63 A Fundação Victor Civita é uma entidade sem fins lucrativos e "voltada para o aperfeiçoamento do professor brasileiro", e tem como missão "contribuir para a melhoria da qualidade da Educação Básica no Brasil e para a formação de novas gerações de leitores, por meio da qualificação do educador da escola pública, com vistas a desenvolver com mais competência suas atividades em sala de aula". A Fundação Victor Civita é independente do Grupo Abril, recebendo apenas apoio financeiro desse grupo e da Gerdau para custear parte de suas atividades, entre elas, a publicação da Revista Nova Escola. Informações disponíveis em <http://revistaescola.abril.com.br/fvc/nossa_historia.pdf>. Acesso em 04 ago. 2008. 
pressupor seus gostos, prioridades, anseios e valores, qualidades que correspondem, em grande medida, às da revista objeto de nossa análise.

Destinada ao grande público docente, a revista Nova Escola trata de assuntos relacionados à educação. Está estruturada em diversas seções e apresenta reportagens sobre experiências de sucesso em sala de aula de todo o País, o que constitui um dos seus diferenciais em relação a outras publicações da área de educação. Suas páginas apresentam um vocabulário simplificado e muitas ilustrações (gráficos, mapas, quadros e fotos de sala de aula envolvendo estudantes e professores) que, conforme sua linha editorial, mostram experiências bem-sucedidas em sala de aula, até porque a Nova Escola não segue uma linha de pensamento, sendo sua pauta definida pelo objetivo de o projeto ser bem-sucedido ${ }^{64}$.

A partir das três edições que compõem o nosso arquivo de pesquisa, analisaremos como, em enunciados de Nova Escola, são construídas (produzidas) identidades para o professor. As edições foram selecionadas por assumirem, marcadamente, a mesma posição-sujeito: trata-se de um sujeito enunciador que pensa antecipadamente os problemas e dificuldades dos professores e antecipa as respostas e soluções, ensinando como é possível chegar a bons resultados.

No enunciado verbal apresentado na capa da edição n. 213, "O que e como ensinar: para garantir o aprendizado em todas as disciplinas, é preciso conhecer os conteúdos essenciais e como lecionar cada um. Veja aqui 30 atividades e oito planos

64 Informações obtidas através de correio eletrônico. SIMEONI, M. C. Atendimento ao leitor de Nova Escola. [mensagem pessoal]. Mensagem recebida por<novaescola@atleitor.com. br> em 07 ago. 2008. 
de aula que todo professor do $1^{\circ}$ ao $5^{\circ}$ ano tem de saber" (Revista Nova Escola, n. 213, jun./jul. 2008), materializa-se uma posição-sujeito autorizada a entrar na "ordem do discurso" do aconselhamento e do ensinamento. De certa forma, a posição aqui assumida desconsidera os fenômenos da descontinuidade e do descentramento do sujeito vistos anteriormente, pois concebe os sujeitos professores como se não fizessem parte de um movimento histórico descontínuo e composto de rupturas, "cesuras que rompem o instante e dispersam o sujeito em uma pluralidade de posições e de funções possíveis" (FOUCAULT, 2009, p. 58).

Em outro enunciado, "Falar bem se aprende na escola: quer que a turma faça bonito em seminários, debates e entrevistas? Vá para a página 42 e veja como" (Revista Nova Escola, n. 230, mar. 2010), novamente a revista em foco parte do princípio de que os professores necessitam de um auxílio para que a turma "faça bonito em seminários, debates e entrevistas", por isso ensina como o professor pode conseguir que a turma fale bem.

O uso de 'como' nesse enunciado atualiza um processo de subjetivação docente que se alicerça em um tipo de discurso pedagógico cristalizado: constituir-se como professor bemsucedido é seguir determinados passos metodológicos, é fazer a "lição de casa" corretamente. Além de dizer o que os bebês aprendem com "cuidado, brincadeira, movimento, alimentação, desenho, faz-de-conta e histórias", a Nova Escola também se propõe a ensinar ao professor 'como' os bebês podem aprender com todos esses itens. Observe-se: "Um dia cheio de aprendizagens: cuidado, brincadeira, movimento, alimentação, desenho, faz de conta e histórias. O que - e como - os bebês aprendem como tudo isso? Saiba na página 42" (Revista Nova Escola, n. 231, abr. 2010). 
Além dessa posição-sujeito - norteada por algumas estratégias de poder -, a revista Nova Escola produz saberes sobre o professor e seu trabalho e assim o coloca em posição de sujeito determinado por processos de subjetivação como, entre outros, exemplos e reflexões sobre "boas" propostas pedagógicas, com teorias, objetivos, metodologias e conteúdos, a determinação dos conteúdos a serem trabalhados e ensinados e o governo de si pelo governo dos outros. Entre as estratégias adotadas para materializar essas práticas de subjetivação, esse veículo midiático prioriza, por exemplo: a autorreferência, isto é, a forma como a revista fala de si em suas reportagens, apresentando-se como conhecedora dos problemas e dificuldades dos professores e oferecendo soluções como modelos a serem seguidos; o uso da opinião e do aval de especialistas experientes para legitimar as narrações postas como verdades; e a informação didatizada, com abundância de exemplos e o uso de vocabulário simples, para "facilitar" o entendimento por parte do leitor e, então, enfatizar seu papel de espectador que precisa de ajuda e de "receitas".

Esse processo de subjetivação é materializado, por exemplo, no seguinte enunciado: "Comunicar-se em diferentes contextos é questão de inclusão social, e é papel da escola ensinar isso’, explica Cláudio Bazzoni, assessor de Língua Portuguesa da Secretaria Municipal de Educação de São Paulo e selecionador do Prêmio Victor Civita - Educador nota 10. O que todo professor precisa incluir em seu planejamento são os chamados gêneros orais formais e públicos, que têm características próprias, pois exigem preparação e apresentam uma estrutura específica" (Revista Nova Escola, n. 230, mar. 2010).

Nesse enunciado o enunciador assume a posição-sujeito de conhecedor das necessidades dos professores e oferece como "solução" para que os estudantes "falem bem em público" o 
exercício de trabalhar com gêneros orais. Para tanto, usa o aval de um especialista na área, o que credibiliza a revista.

Não obstante, vale lembrar que a Nova Escola não considera os fatores histórico-sociais que podem influenciar as práticas docentes, mas argumenta que todos, independentemente da realidade, devem seguir as mesmas estratégias. Isso sinaliza um mecanismo discursivo de produção de identidade docente por meio de um conjunto de saberes sobre a prática pedagógica, a qual passa, então, a ser controlada e organizada por esse discurso.

Com base na tese de Foucault sobre o descentramento do sujeito na história e sobre a sua dispersão nos acontecimentos discursivos, acreditamos ser necessário colocar em suspenso - e mesmo questionar - certas vontades de verdade, como as que organizam os efeitos de sentido da prática docente produzidos pelos enunciados aqui analisados, em especial na afirmação de que "para garantir o aprendizado em todas as disciplinas, é preciso conhecer os conteúdos essenciais e como lecionar cada um” (RNE n. 213). Como sabemos, há diversos sujeitos vivendo diferentes temporalidades em um mesmo momento histórico, e o conhecimento dos conteúdos essenciais pode não bastar para garantir o aprendizado em todas as disciplinas e em quaisquer turmas de estudantes.

\section{Últimas considerações}

Bauman (2001) pondera que a sociedade atual está na chamada "Modernidade líquida", considerando-a como fluida, líquida. Por analogia, também os sujeitos deveriam ser líquidos, 
fluidos; porém a revista Nova Escola apresenta formas de identificação para o sujeito professor que não se coadunam com as características dos sujeitos na "Modernidade líquida", pois, ao materializar enunciados que produzem essa identidade fixa e constante, esse periódico determina tão fortemente as bases, os encaminhamentos e os "bons" exemplos de práticas docentes, que o professor acaba sendo "anulado".

Pelo levantamento que fizemos, concluímos que as proposições da Nova História são operantes nos e para os trabalhos de análise do discurso que também tenham como objetivo estudar os processos de constituição de identidades para os sujeitos; afinal, como afirma Foucault, nada no "homem é bastante fixo", portanto, as identidades também não são fixas nem inatas, mas construídas - também pela mídia.

Como as identidades são produzidas discursivamente, é necessário compreendê-las como relacionadas a locais sóciohistóricos e institucionais (como a mídia) no interior de formações e práticas discursivas e ligadas a sistemas de representação - e por isso, como um ato de poder, sendo ainda instáveis, contraditórias, fragmentadas, inacabadas. "As identidades são, pois, pontos de apego temporário às posições-de-sujeito que as práticas discursivas constroem para nós" (HALL, 1995 apud HALL, 2000, p. 112). Neste sentido, outro aspecto a ser considerado é que a produção de identidades está relacionada ao modo como os sujeitos são posicionados nos discursos.

A mídia impõe qual prática é aceitável e determina como os professores devem agir, e assim constrói coletividades. Os professores que não se nortearem pelas propostas da Nova Escola, que não se enquadrarem nas práticas impostas por essa revista, terão sua identidade vista como "não certificada" (BAUMAN, 
2005, p. 28). O sujeito é constantemente subjetivado pelos efeitos da mídia, que constrói coletividades e, neste caso, constrói para o professor uma identidade que, conforme já afirmamos, apresenta-se como uma regularidade.

\section{Referências}

BAUMAN, Z. Modernidade líquida. Tradução Plínio Dentzien. Rio de Janeiro: Jorge Zahar, 2001.

. Identidade. Tradução Carlos Alberto Medeiros. Rio de Janeiro: Jorge Zahar, 2005.

FERNANDES, C. A. Discurso, história e arqueologia: entrevista com JeanJacques Courtine. In: MILANEZ, N; GASPAR, N. R. (Orgs.). A (des)ordem do discurso. São Paulo: Contexto, 2010. p. 17 - 30.

FOUCAULT, M. Microfísica do poder. Tradução e organização Roberto Machado. Rio de Janeiro: Edições Graal, 1979.

. Nietzsche, a genealogia, a História. In: . Organização

e seleção de textos: Manoel Barros da Motta. Tradução Elisa Monteiro. Arqueologia das ciências e história dos sistemas de pensamento. 2. ed. Rio de Janeiro: Forense Universitária, 2005. p. 260 - 281. (Ditos e Escritos II).

Retornar à História. In: Organização e seleção de textos: Manoel Barros da Motta. Tradução Elisa Monteiro. Arqueologia das ciências e história dos sistemas de pensamento. 2. ed. Rio de Janeiro: Forense Universitária, 2005. p. 282 - 295. (Ditos e Escritos II).

- A arqueologia do saber. Tradução Luiz Felipe Baeta Neves. 7. ed. Rio de Janeiro: Forense Universitária, 2007.

- A ordem do discurso. Tradução Laura Fraga de Almeida Sampaio. 4. ed. São Paulo: Loyola, 2009. 
HALL, S. Quem precisa de identidade? In: SILVA, T. T. da. (Org.). Tradução Tomaz Tadeu da Silva. Identidade e diferença: a perspectiva dos estudos culturais. Petrópolis, RJ: Vozes, 2000. p. 103 - 133. - A identidade cultural na pós-Modernidade. Tradução Tomaz Tadeu da Silva e Guacira Lopes Louro. 10. ed. Rio de Janeiro: DP\&A, 2005.

GREGOLIN, M. do R. J.-J. Courtine e as metamorfoses da análise do discurso: novos objetos, novos olhares. In: SARGENTINI, V; GRAGOLIN, M. do R. (Orgs.). Análise do discurso: heranças, métodos e objetos. São Carlos, Claraluz, 2008. p. $21-36$.

NAVARRO-BARBOSA, P. L. O acontecimento discursivo e a construção da identidade na História. In: SARGENTINI, V.; NAVARRO-BARBOSA, P. (Orgs.). Foucault e os dominios da linguagem: discurso, poder, subjetividade. São Carlos: Claraluz, 2004. p. 97 - 130.

. O pesquisador da mídia: entre a "aventura do discurso" e os desafios do dispositivo de interpretação da AD. In: NAVARRO, P. (Org.). Estudos do texto e do discurso: mapeando conceitos e métodos. São Carlos: Claraluz, 2006. p. $67-92$.

Discurso, história e memória: contribuições de Michel Foucault ao estudo da mídia. In: TASSO, I. (Org.). Estudos do texto e do discurso: interfaces entre língua(gens), identidade e memória. São Carlos: Claraluz, 2008. p. 59 74.

REVISTA NOVA ESCOLA. São Paulo: Fundação Victor Civita, n. 213, jun./jul. 2008.

. São Paulo: Fundação Victor Civita, n. 230, mar. 2010.

. São Paulo: Fundação Victor Civita, n. 231, abr. 2010. 